$$
\begin{aligned}
& \text { University of Szeged } \\
& \text { Faculty of Pharmacy }
\end{aligned}
$$

Department of Pharmaceutical Technology

Head: Prof. Dr. Piroska Szabó-Révész

Ph.D. Thesis

\title{
FORMULATION AND INVESTIGATION OF \\ ERODING HYDROPHILIC MATRIX SYSTEMS
}

by

Gabriella Baki

Pharmacist

Supervisors:

Prof. Dr. Klára Pintye-Hódi and Dr. János Bajdik

Szeged

2011 


\section{PUblications Related TO THE THESIS}

I. J. Bajdik, G. Baki, A. Kelemen, K. Pintye-Hódi: The effect of wetting of powder mixture on the preparation of hydrophilic matrix granules with high-shear granulator Chem. Eng. Res. Des. 86, 1-7, 2008

$$
I F=0.989
$$

II. J. Bajdik, G. Baki, Zs. Szent-Királlyi, K. Knop, P. Kleinebudde, K. Pintye-Hódi: Evaluation of the composition of the binder bridges in matrix granules prepared with a small-scale high-shear granulator

J. Pharm. Biomed. Anal. 49, 694-701, 2008

$I F=2.629$

III. G. Baki, J. Bajdik: Vaginal dosage forms

Gyógyszerészet (Journal of the Hungarian Society for Pharmaceutical Sciences MGYT), 2008/9., 521-528

IV. G. Baki, J. Bajdik, A. Kelemen, K. Pintye-Hódi: Formulation of a solid intravaginal matrix system to prolong the $\mathrm{pH}$-decreasing effect of lactic acid

$$
\text { J. Drug Del. Sci. Tech. 19, 133-137, } 2009 \quad I F=0.440
$$

V. G. Baki, J. Bajdik, K. Pintye-Hódi: Evaluation of powder mixtures and hydrophilic gastroretentive drug delivery systems containing zinc acetate and sodium bicarbonate J. Pharm. Biomed. Anal. 54, 711-716, 2011

$I F=2.453$

\section{Presentations RELATED TO THE THESIS}

I. G. Baki: Formulation and investigation of eroding vaginal matrix systems Conference of Student Research Program (TDK), Szeged, Hungary, 2007

II. J. Bajdik, G. Baki, A. Kelemen, K. Pintye-Hódi: Formulation of long-acting solid intravaginal matrix systems containing lactic acid $2^{\text {nd }}$ BBBB Conference on Pharmaceutical Sciences, Tallinn-Tartu, Estonia, 2007

III. G. Baki, J. Bajdik, Zs. Szent-Királlyi, Knop K., Kleinebudde P., K. Pintye-Hódi: Optimization of the formulation of hydrophilic matrix systems MGYT Symposium on Pharmaceutical Research, Szeged, Hungary, 2007 
IV. G. Baki: Formulation of an eroding hydrophilic matrix system Hungarian Science Festival, Szeged, Hungary, 2008

V. G. Baki: Formulation and investigation of vaginal matrix tablets $9^{\text {th }}$ “Ottó Clauder" Memorial Competition, Budapest, Hungary, 2009

VI. G. Baki: J. Bajdik, K. Pintye-Hódi: Formulation and investigation of a gastroretentive matrix system $16^{\text {th }}$ National Pharmaceutical Technology Conference and $8^{\text {th }}$ „Medicine on the turn of the millennium” Postgraduate Conference, Siófok, Hungary, 2010

VII. G. Baki, J. Bajdik, K. Pintye-Hódi: Evaluation of powder mixtures and hydrophilic drug delivery systems containing zinc acetate and sodium bicarbonate $7^{\text {th }}$ World Meeting on Pharmaceutics, Biopharmaceutics and Pharmaceutical Technology, Malta, Valetta, 2010

\section{OTHER}

I. G. Baki: Formulation and investigation of a long-acting vaginal matrix system Szeged Talent Program award work, 2007

II. G. Baki: Formulation and investigation of eroding hydrophilic matrix tablets Regional Committee in Szeged of the Hungarian Academy of Sciences award work, 2008 


\section{Content}

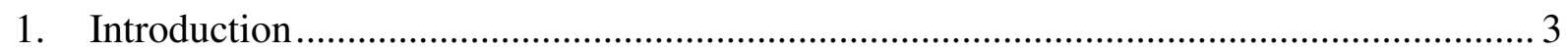

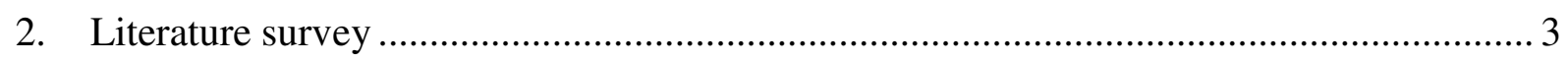

2.1. Programming of the effect of solid dosage forms ...................................................... 3

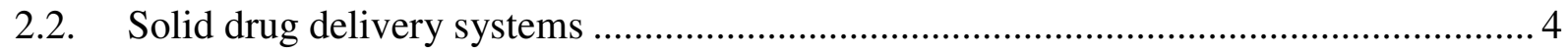

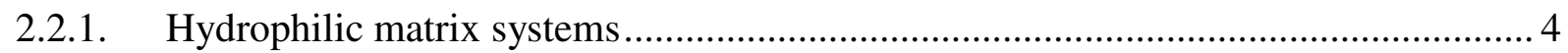

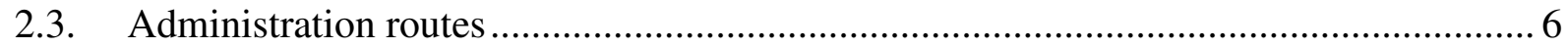

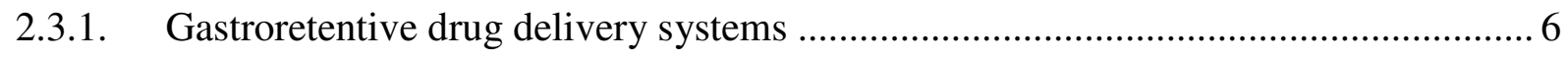

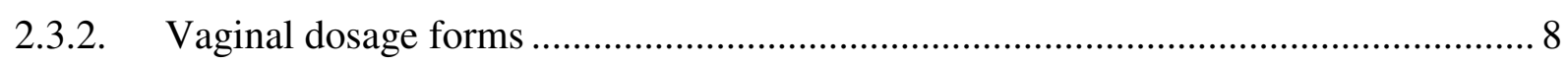

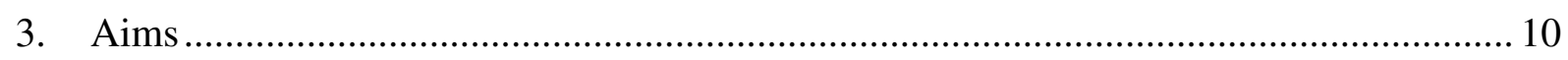

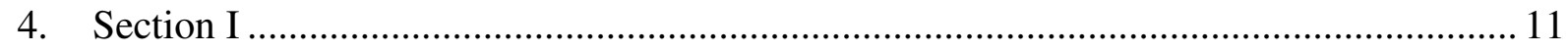

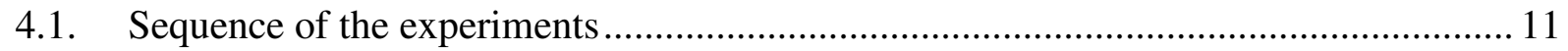

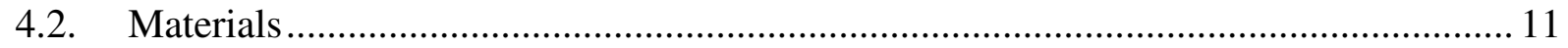

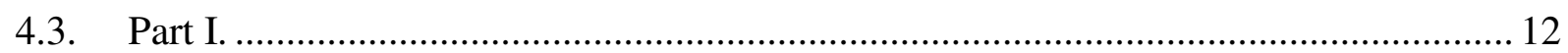

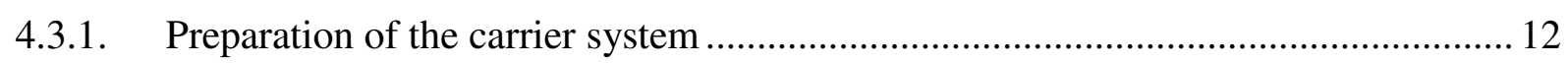

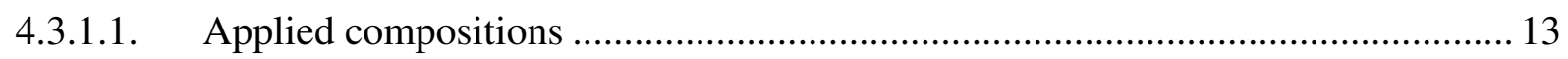

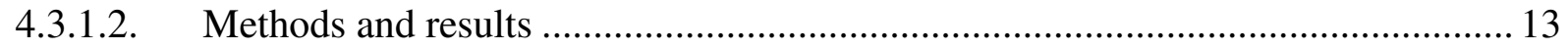

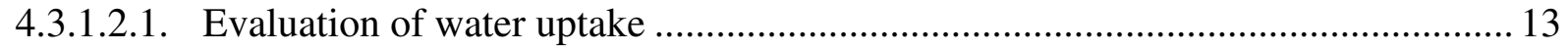

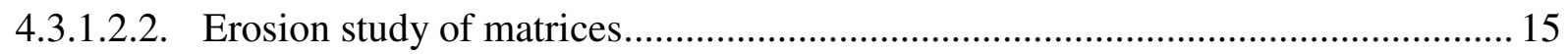

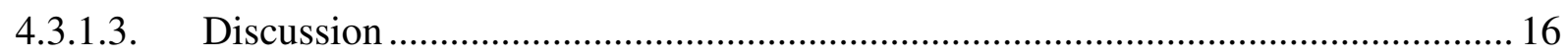

4.3.2. Determination of the optimum quantity of granulating fluid .................................. 17

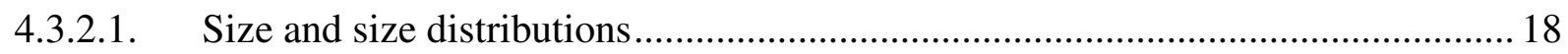

4.3.3. Optimization of the granulating process.............................................................. 18

4.3.3.1. Temperature elevation during granulation .......................................................... 20

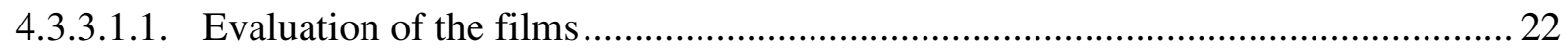

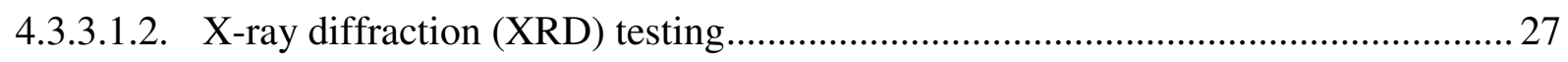

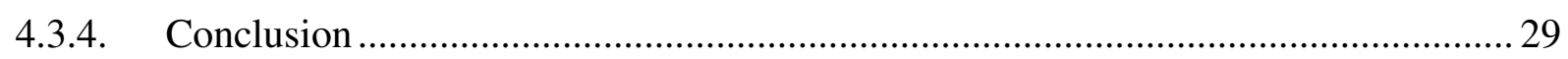

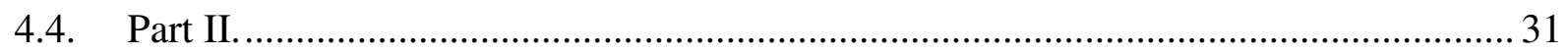

4.4.1. Preparation of matrix granules containing lactic acid ........................................... 31

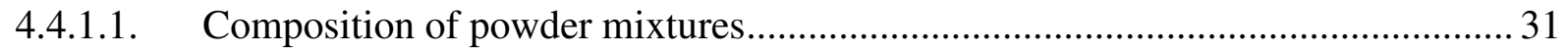

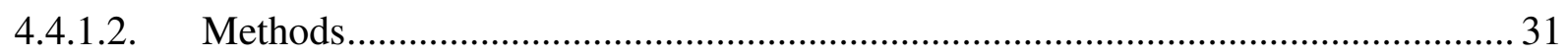

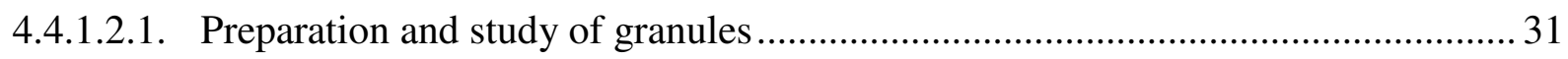




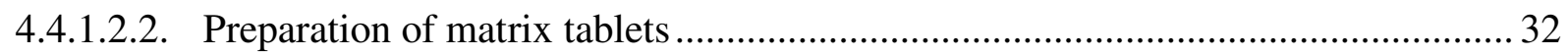

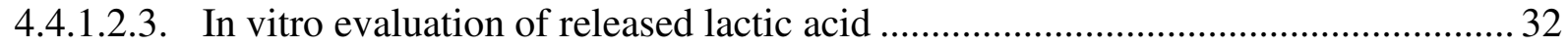

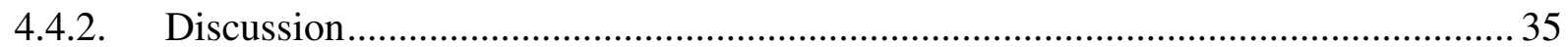

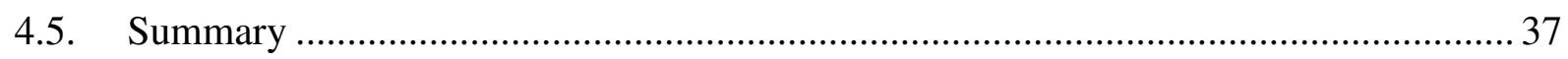

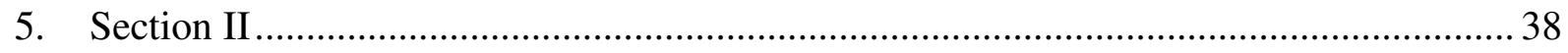

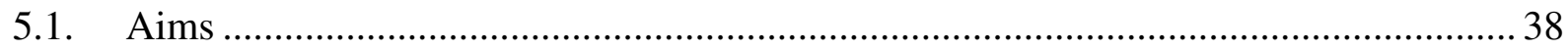

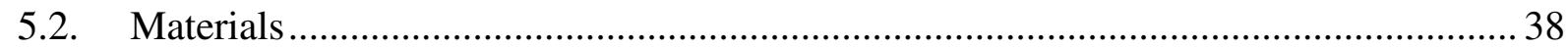

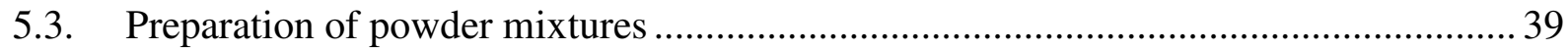

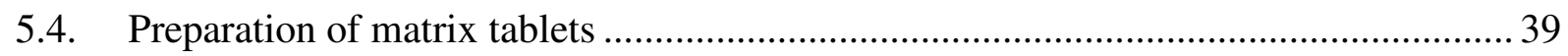

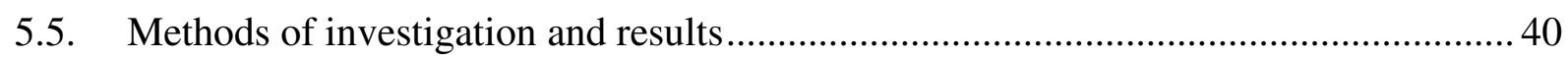

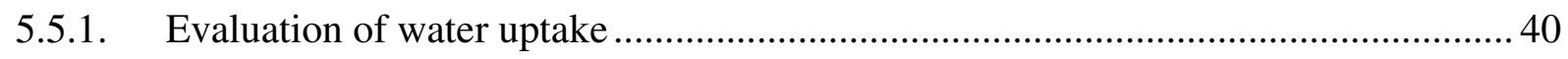

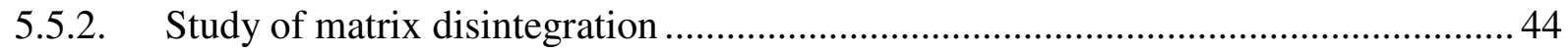

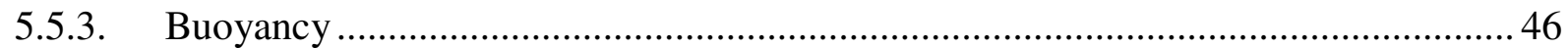

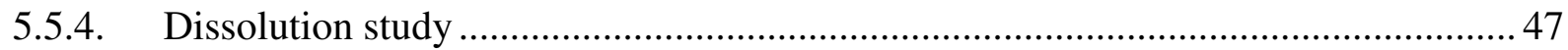

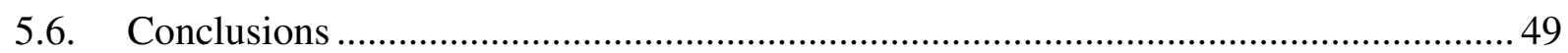

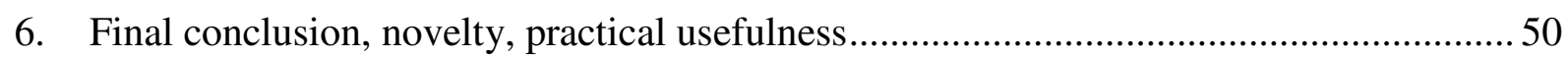

7. References

8. Acknowledgements

Appendix 


\section{INTRODUCTION}

Efforts to innovate existing medication include the development of medicines with higher selectivity of action, less toxicity and side-effects, higher stability, a more favorable pharmacokinetic profile and improved patient compliance. At the administration of solid dosage forms, the active pharmaceutical ingredients (APIs) have to bind their own receptors in an optimal concentration to affect the body. It is influenced by liberation, absorption and elimination, but it can be modified with special pharmaceutical technological methods.

Modern pharmaceutical technology concentrates on new dosage forms which are targeted to the exact site at the appropriate time, with maximum efficiency and with reduced side effects. These dosage forms can be found for example in the European Pharmacopoeia and United States Pharmacopeia; and they are named as systems with sustained release, delayed release or pulsatile release. In these systems the dissolution of the APIs are accurately controlled by special composition and/or by special manufacturing process.

The properties of additives and APIs applied in pharmaceutical experiments rarely make possible the direct processibility, therefore we should use some intermediate steps, such as granulation, in the development of complete dosage forms.

\section{LITERATURE SURVEY}

\subsection{Programming of the effect of solid dosage forms}

The best new therapeutic entity in the world is of little value without an appropriate delivery system. Tableted drug delivery systems can range from relatively simple immediate release formulations to complex extended or modified release dosage forms. The most important role of a drug delivery system is to get the drug delivered to the site of action in sufficient amount and at the appropriate rate; however, it must also meet a number of other essential criteria. These include physical and chemical stability, ability to be economically mass produced in a manner that assures the proper amount of drug in each and every dosage unit and in each batch produced, and, as far as possible, patient acceptability - for example reasonable size and shape, taste, color to encourage patients to take the drug and thus comply with the prescribed dosing regimen [1].

At sustained release preparations the rate and/or place of release of the active substance(s) is different from that of a conventional release dosage form administered by the same route. This deliberate modification is achieved by a special formulation design and/or manufacturing method [2]. 
Controlled release delivery systems offer four principle advantages over conventional formulations that deliver all of the APIs over a short period of time. These are the following:

- more constant plasma level of API(s),

- site of action delivery (this technology makes possible both the delivery of the agent locally and its containment at the site of action),

- more efficient utilization of agents,

- less frequent administration [3].

\subsection{Solid drug delivery systems}

The majority of currently marketed modified release dosage forms fall into one of the following three technologies:

1. Monolithic (matrix) systems: hydrophilic, hydrophobic or inert matrices. In these systems, the drug is homogeneously dispersed or dissolved in a soluble or insoluble matrix [4] and it is released by diffusion and erosion from the polymer.

2. Reservoir (coated) systems where drug-containing core is enclosed within polymer coatings [5]. In membrane-controlled reservoir devices, the drug is released by diffusion through this rate-controlling membrane.

3. Osmotic pump systems.

Different solid matrix systems have often proven popular among controlled drug delivery technologies because of their simplicity, ease of manufacturing, high level of reproducibility, stability of the raw materials and dosage form, and ease of scale-up and process validation and their controlling effects on the dissolution of APIs [6]. This is reflected by the large number of patents filed each year and by the commercial success of a number of novel drug delivery systems based on matrix technologies [7].

In my work, two hydrophilic matrix systems were chosen. One of them is a swelling controlled delivery system, which is a special approach to developing an orally applicable system, the release of the API in the other system is controlled by mainly erosion and diffusion through the gel layer; this is intended to be applied intravaginally.

\subsubsection{Hydrophilic matrix systems}

Of all drug forms, solid oral dosage is overwhelmingly preferred by patients, and hydrophilic matrix systems are among the most widely used means of providing controlled release in solid oral dosage forms. 
Drugs dispersed in a soluble matrix rely on a slow dissolution of the matrix to provide sustained release. If the matrix is presented with a conventional tablet geometry, then on contact with dissolution media the surface area of the matrix decreases with time, with a concomitant decrease of drug release (Figure 1, [8]). The classic description of the events following immersion of a matrix in aqueous media is as follows:

- Surface drug (if water soluble) dissolves and gives a 'burst effect'.

- The hydrophilic polymer hydrates and an outer gel layer forms.

- The gel layer becomes a barrier to uptake of further water and to the transfer of drug.

- Drug (if soluble) release occurs by diffusion through the gel layer; insoluble drug is released by erosion followed by dissolution.

- Following erosion, the new surface becomes hydrated and forms a new gel layer [4].

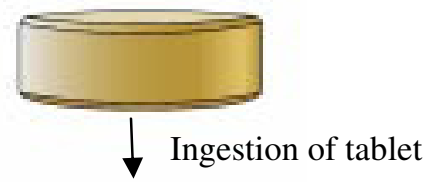

Initial wetting: Tablet surface wets, and begins to hydrate forming a gel layer. Drug near the surface of the tablet is released.

Expansion of gel layer: Water permeates into the tablet, increasing the thickness of the gel layer, soluble drugs diffuse through the gel layer. Polymer relaxation in the dry core also contribute to dosage swelling.

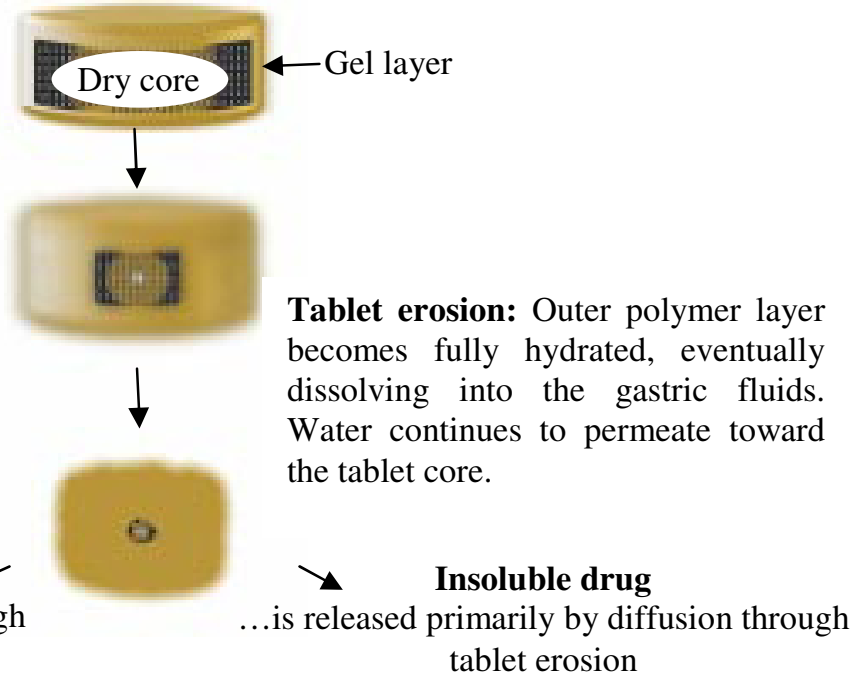

...is released primarily by diffusion through the gel layer tablet erosion

Figure 1. Drug release from a matrix tablet

Of the available range of cellulosic controlled-release agents, hydroxypropyl methylcellulose (HPMC) is the most widely used. HPMC a semisynthetic derivative of cellulose, it has its popularity for the formulation of controlled release dosage forms as a swellable and hydrophilic polymer [9-11]. It is a well-known excipient with an excellent safety record. Its nontoxic property, ease of handling, ease of compression, ability to accommodate a large percent of drug, negligible influence of the processing variables on drug release rates, and relatively simple tablet manufacturing technology make it an excellent 
carrier material [12]. It is nonionic, so it minimizes interaction problems when used in acidic, basic, or other electrolytic systems. HPMC works well with soluble and insoluble drugs at high and low dosage levels [8]. As the outer gel layer of the tablet fully hydrates and dissolves, a new inner layer must replace it and be cohesive and continuous enough to retard the influx of water and control drug diffusion. Although gel strength is controlled by polymer viscosity and concentration, polymer chemistry also plays a significant role. Evidence suggests that the chemistry of HPMC encourages a strong, tight gel formation compared to other cellulosics. As a result, drug release rates have been sustained longer with HPMC than with equivalent levels of methylcellulose, hydroxyethylcellulose, or carboxymethylcellulose $[8]$.

\subsection{Administration routes}

The choice of a delivery route is driven by patient acceptability, the properties of the drug, such as its solubility, access to a disease location, or effectiveness in dealing with the specific disease [13]. The drug action can be variously influenced with different dosage forms, such as gels, TTSs, microemulsions [14-16] at a given site of action. Nowadays, oral administration is still the most convenient and preferred means of any drug delivery to the systematic circulation [17], this route is still the most intensively investigated as it offers advantages of convenience and cheapness of administration, and potential manufacturing cost savings. In case of oral administration, the exact site of action can be accurately determined, in case of e.g. APIs acting in the colon, gastroretentive drug delivery systems, buccal dosage forms. Besides this, there are many other frequently applied delivery sites, such as the lungs in pulmonary delivery systems, or the skin in case of transdermal drug delivery, and numerous parenteral routes [13]. Vaginal administration route also need to be emphasized as this dosage form has been developed and used clinically for many years in local therapy and systemic delivery of systemically effective drugs [18-20].

\subsubsection{Gastroretentive drug delivery systems}

In recent years scientific and technological advancements have been made in the research and development of rate-controlled oral drug delivery systems by overcoming physiological adversities, such as short gastric residence times (GRT). These drug delivery systems may be desirable for drugs with an absorption window in the stomach or in the upper small intestine $[21,22]$, it is also useful for drugs that act locally in the proximal part of the GI tract [23-25], 
and for drugs that are poorly soluble or unstable in the intestinal fluid [26, 27]. Several approaches are currently utilized in the prolongation of the GRT, including floating drug delivery systems (FDDSs) [28-30], also known as hydrodynamically balanced systems; swelling and expanding systems [31-34]; polymeric bioadhesive systems [35-37]; modifiedshape systems [38-42]; high-density systems [43-45], and other delayed gastric emptying devices $[46,47]$.

To comprehend the considerations taken in the design of GRDFs and to evaluate their performance, the factors controlling gastric retention of dosage forms should be fully understood. These include the following: density, size and shape of the dosage form [48, 49], food intake and its nature [50], caloric content and frequency of intake [51-53], osmolarity and $\mathrm{pH}$ of food [54], posture [55], gender, age [56], sex, sleep, body mass index, mental stress and disease state of the individual [57-60], and administration of drugs with impact on GI transit time, for example drugs acting as anticholinergic agents, opiates and prokinetic agents $[61,62]$. The molecular weight and lipophilicity of the drug depending on its ionization state are also important parameters [63].

The process of gastric emptying occurs both during fasting and fed states; however, the pattern of motility differs markedly in the two states: the motoric activity in the fasting state, termed interdigestive myoelectric motor complex (IMMC) is a 2-h cycle of peristaltic activity that is generated in the stomach, and progresses aborally to the ileocecal junction. Its aim is to clear the stomach and the small intestine [50]. It is composed of four phases: phase 1 lasts 45-60 min, is quiescent, with rare low amplitude contractions; phase 2 with a length of 30-45 min, has intermediate amplitude contractions [64], phase 3 is also termed 'housekeeper wave' and extends for 5-15 min. Very high amplitude contractions, with a frequency of 4-5 per min [54], and maximal pyloric opening [65], characterize this phase. The motor activity in the fed state is induced 5-10 min after ingestion of a meal and persists as long as food remains in the stomach. The larger the amount of food ingested, the longer the period of fed activity, with usual time spans of 2-6 h, and more typically, 3-4 h. Its phasic contractions are similar to those seen during phase 2 of the IMMC.

FDDSs have a bulk density lower than the gastric content and thus they remain buoyant in the stomach for a prolonged period of time, with the potential for continuous release of drug. Based on the mechanism of buoyancy, two distinctly different technologies, i.e., noneffervescent [66-70] and effervescent [71-73] systems have been utilized in the development of FDDSs. Effervescent buoyant delivery systems typically utilize matrices prepared with swellable polymers such as HPMC and effervescent components, e.g., sodium 
bicarbonate and citric or tartaric acid [74]. The matrices are manufactured so that upon arrival in the stomach, carbon dioxide is liberated by the acidity of the gastric contents and is entrapped in the gellified hydrocolloid. This produces an upward motion of the dosage form and maintains its buoyancy. A decrease in specific gravity causes the dosage form to float on the chyme [75].

\subsubsection{Vaginal dosage forms}

Intravaginal preparations can be applied to treat various topical problems; because of the good absorption and the lack of first pass effect, this route can be utilized to cure systemic diseases, mainly by hormone replacement [76-78].

Recently, the vagina's absorption capacity has been recognized, which suggests that the vagina could provide a potential route for systemic drug delivery with a direct entry to the blood stream with the possibility of bypassing the hepatic-gastrointestinal metabolism. Use of the vaginal route as a novel site for drug delivery has recently received greater attention.

The most important factors controlling the phamacokinetics of vaginal drug delivery systems include the following.

Despite the paucity of glands, the vaginal epithelium is usually kept moist by a surface film. This film, known as vaginal fluid, consists of cervical mucus, exfoliated cells from the vagina itself and also small amounts of the secretion from the Bartholin's glands in the vaginal wall. Transudation from the blood vessels through the intracellular channels to the lumen can also contribute to the chemical composition. The quantity of this liquid is about 3-4 g, but it varies during the normal menstrual cycle. The vaginal secretion, which serves as a protective barrier against infections, contains a variety of antimicrobial substances, carbohydrates, acids and proteins.

Typically, the vaginal fluid in mature, healthy women has a $\mathrm{pH}$ in the range 4.0-5.0 [79], it is controlled primarily by lactic acid (LA) produced from cellular glycogen, or by carbohydrates produced by the action of normal vaginal microflora. The lowest values are found at mid-cycle and the highest during menstruation. During pregnancy, the $\mathrm{pH}$ is the lowest, it varies between 3.8 and 4.8 [80]. As there is a correlation between the required acidic $\mathrm{pH}$ of the vaginal secretions and the inhibition of Chlamydial infections, maintenance of the optimum $\mathrm{pH}$ of the vaginal fluid is therefore inevitable.

The variety of enzymes found in the vagina is an important concern for the development of vaginal delivery systems. In addition to enzymes, the vaginal lumen is a non-sterile area inhabited by a variety of microorganisms mainly Lactobacillus, Bateroides and 
Staphylococcus epidermidis, as well as potentially pathogenic aerobes. The existence of these microbes and their metabolites may also have a detrimental effect on the intravaginal stability of a vaginal drug delivery device [79].

For restoring the normal $\mathrm{pH}$ and for providing the required acidic environment, different acidic liquids are applied as irrigation fluids, but a large amount of such liquid can cause the washing-out of the Lactobacillus flora and the effects of these materials are not long-lasting. In addition, the application of such liquid is inconvenient. Solid preparations containing various Lactobacillus species and other lactic acid-producing organisms have been used in the treatment of vaginal disorders, but evidence to support their use is limited. Because of this situation, the formulation of a solid dosage form containing a long acting acidifying component - if possible LA - is reasonable [81]. 


\section{AIMS}

The aim of this study was the formulation and investigation of solid, erodible, hydrophilic matrix systems. These matrix systems were planned to be applied via different administration routes, thus different model APIs were chosen for the formulation. One of the systems was planned to be administered intravaginally to restore normal vaginal $\mathrm{pH}$. The intended system would have sustained release and effect locally in the vagina, and could be used in the treatment of gynecological conditions caused by changed $\mathrm{pH}$, e.g. irritation. The other drug delivery system was a gastroretentive matrix system that might be therapeutically effective in Wilson's disease. It would also have sustained release and float in the stomach for hours. The hydrophilic matrix former was different types of HPMC in both drug delivery systems, thus the mechanism of disintegration and the API's dissolution through the gel layer were the same, however some major characteristics, such as swelling and viscosity differed between the types.

In the selection of additives, bioadhesive (mucoadhesive) and bioerodible properties of the materials were taken into consideration; thus the solid dosage form would not irritate the mucus membrane in the vagina and the stomach; and on the other hand, mucoadhesiveness would make possible the attachment of the tablet to the vaginal wall and the wall of the stomach, and the control of the API's liberation.

A strong acid and a metal ion having a net positive charge of +2 , usually being in interaction with the majority of polymers were applied in the delivery systems as APIs, thus the curiosity of this work was the investigation of APIs' effect on the properties of polymer matrices influencing the APIs' release.

As two different drug delivery systems were formulated and investigated, they are described and discussed separately. First, the vaginal system, after that, the gastroretentive delivery system is to be detailed. 


\section{SECTION I}

\subsection{Sequence of the experiments}

Solid intravaginal preparations can contain very small amounts of APIs, e.g. $\mu$ g quantities of hormones, and it is well known that the processibility of these materials is very difficult [77]. These tablets are usually larger than conventional oral tablets (about 1-1.5 g) - because of the easier application - but in contrast, the effects of the APIs are less relevant in the properties of these pharmaceutical dosage forms, e.g. wetting properties, dissolution. The determining factors are the composition (type and quantity) of the additives - it is the so-called carrier system - and the operational parameters during the preparation.

In this study, the sequence that is usually applied in pharmaceutical research was followed. On the ground of that, the experiments can be divided into two parts. First, the properties of the starting materials were studied; then matrices without the API were prepared; and finally the complete system with LA were produced and examined.

\subsection{Materials}

Lactic acid (LA) (Hungaropharma Plc., Budapest, Hungary) was applied as a model API having a pH-decreasing effect. LA, also called milk acid is syrupy, odorless, colorless or slightly yellow-colored, viscous, hygroscopic, non-volatile [2] water-soluble liquid, which is very important in the vagina's self-defense cycle. It is prepared by the fermentation of carbohydrates, such as glucose, sucrose and lactose, with microorganisms whose growth is in turn also facilitated by LA. Lactobacilli are a kind of good bacteria which produces LA that keeps the vagina safe from germ invasion. LA creates an acidic environment to guard the vagina from an overgrowth of harmful bacteria which leads to different infections. The greater the number of Lactobacilli, the more stable the natural acidic environment is for the vagina.

Because of the favorable effects of LA, its incorporation into a solid dosage form can be very beneficial. As it has been detailed before, different acidic liquids may be applied as well, but a large amount of such liquid can cause the washing-out of the Lactobacillus flora, their effects are not long-lasting, and their application is inconvenient. A small amount of liquid can be formulated into tablets. In this case, the liquid is incorporated into the granulating fluid and the application of components which can bind this material is also necessary [82]. 
Hydroxypropyl methylcellulose (HPMC) (Pharmacoat 606 Type 2910, Shin-Etsu Chemical Co., Ltd., Tokyo, Japan) was used as a matrix forming agent. Ph. Eur. describes HPMC as a partly O-methylated and O-(2 hydroxypropylated) cellulose. This component is frequently utilized to form intravaginal bioadhesive systems [83]. It is a white or light gray pellet or fibril powder with odorless and tasteless properties. It expands to clear or slightly muddy colloid solution in cold water.

Microcrystalline cellulose (MCC) (Vivapur 301, Rettenmaier\&Söhne GmbH, Rosenberg, Germany) was applied as a filler/binder. MCC is purified, partially depolymerised cellulose that occurs as a white-colored, odorless, tasteless, crystalline powder composed of porous particles. Its porosity promotes easy wetting and rapid drying of wet granulation and exhibits good volumetric flow characteristic with low lubricant demand. The fibres of this filler/binder agent were used to bind the liquid (they act as a carrier) [84].

$\boldsymbol{\alpha}$-Lactose monohydrate (Hungaropharma Plc, Budapest, Hungary) was used as a filler. It is white to off-white crystalline particle or powder, it is odorless and slightly sweet-tasting. The most common form of lactose used in pharmaceutical formulation is crystalline $\alpha$-lactose monohydrate [85]. Solid vaginal products often contain lactose as filler, since this is a natural substrate for the vaginal microflora, which converts lactose into LA [84].

\subsection{Part I.}

The aim of this part was to determine the main factors which can influence the preparation of hydrophilic matrices and to choose the best parameters for the production of granules. As the API was liquid, granulation was the chosen method of production, and from the different granulating methods, high-shear granulation was applied.

\subsubsection{Preparation of the carrier system}

Preformulation is a stage of development during which the physicochemical properties of drug substances are characterized [86]. The objective of preformulation studies is to develop a portfolio of information about the drug substance to serve as a set of parameters against which detailed formulation design can be carried out. Preformulation investigations are designed to identify those physicochemical properties of drug substances and excipients that may influence the formulation design, method of manufacture, and pharmacokineticbiopharmaceutical properties of the resulting product [79]. 


\subsubsection{Applied compositions}

The ratio of the filler components was 1:1 in all samples. Compositions of the powder mixtures were as follows (Table 1).

Table 1. Compositions of powder mixtures

\begin{tabular}{cccc}
\hline Sample & HMPC & Lactose & MCC \\
\hline Mix0 & $0 \%$ & $50 \%$ & $50 \%$ \\
Mix10 & $10 \%$ & $45 \%$ & $45 \%$ \\
Mix20 & $20 \%$ & $40 \%$ & $40 \%$ \\
Mix30 & $30 \%$ & $35 \%$ & $35 \%$ \\
Mix40 & $40 \%$ & $30 \%$ & $30 \%$ \\
Mix50 & $50 \%$ & $25 \%$ & $25 \%$ \\
\hline Mix 100 (HPMC) & $100 \%$ & $0 \%$ & $0 \%$ \\
\hline
\end{tabular}

\subsubsection{Methods and results}

\subsection{Evaluation of water uptake}

Enslin number is a simple semi-quantitative measure of water uptake of powders. It is equal to the amount of fluid absorbed by $1 \mathrm{~g}$ of the powder $(\mathrm{mL} / \mathrm{g})$. An Enslin apparatus with a glass filter and a pipette with $0.01 \mathrm{~mL}$ accuracy were used for these experiments. A monolayer of particles took up the maximum quantity of water possible through a filter paper under these conditions [87]. $0.5 \mathrm{~g}$ of each powder was tested; 5 parallel experiments were performed.

The speed of water uptake can be evaluated via characteristic water uptake time $\left(\mathrm{t}_{63.2 \%}\right)$. It is the time which is necessary for the uptake of $63.2 \%$ of the maximum quantity of water [88]. The fitting revealed that these curves can be described by the Weibull-model. A non-linear fitting approach with the following equation was applied:

$$
\mathrm{M}=\mathrm{M}_{0}\left\{1-\exp \left[-\frac{(\mathrm{t}-\mathrm{T})^{\beta}}{\mathrm{a}}\right]\right\} \begin{aligned}
& \mathrm{M}=\text { amount of water taken up after time ' } \mathrm{t} \text { ' } \\
& \mathrm{M}_{0}=\text { maximum amount of water taken up } \\
& \mathrm{T}=\text { delay time } \\
& \beta=\text { shape parameter } \\
& \mathrm{a}=\text { time parameter }
\end{aligned}
$$

First, the water uptake of the starting materials was measured. It can be seen in Table 2 that the highest quantity was detected for MCC and the lowest for HPMC. In case of HPMC, this low value can be explained by the gel forming properties of the matrix forming polymer, so a thin gel layer formed and it inhibited or slowed down further wetting. The values for the 
mixtures were intermediate between these results, and the characteristics of the wetting curves were very similar (Figure 2), but it can be seen that the changes were not linear.

Table 2. Enslin numbers of samples

\begin{tabular}{cc}
\hline Sample & $\begin{array}{c}\text { Enslin number } \\
(\mathbf{m L / g})\end{array}$ \\
\hline Lactose & $0.3791 \pm 0.1276$ \\
MCC & $2.2361 \pm 0.0283$ \\
Mix0 & $1.1692 \pm 0.0428$ \\
Mix10 & $0.8822 \pm 0.0680$ \\
Mix20 & $0.4711 \pm 0.0184$ \\
Mix30 & $0.2553 \pm 0.0090$ \\
Mix40 & $0.1996 \pm 0.0141$ \\
Mix50 & $0.1945 \pm 0.0098$ \\
Mix100(HPMC $)$ & $0.1876 \pm 0.0229$ \\
\hline
\end{tabular}

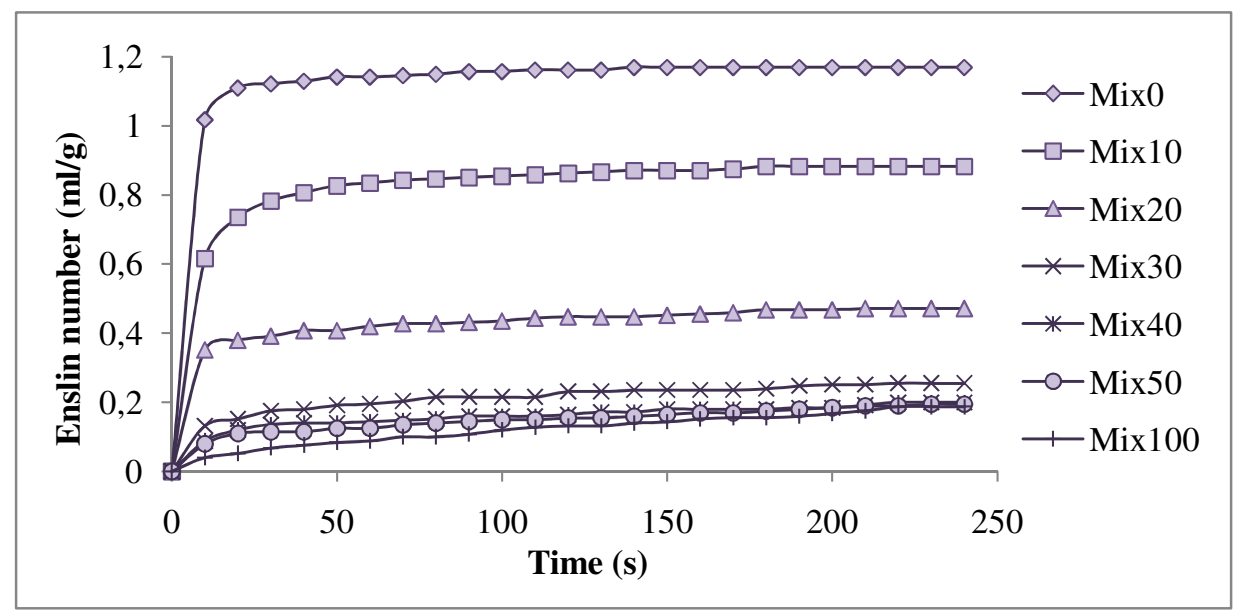

Figure 2. Wetting curves of the samples

It can be seen in Figure 3 that the higher the concentration of HPMC, the lower the Enslin number of the samples is. The curves become linear at approximately $40 \%$ HPMC content and it means that the binder does not induce a significant change in the wetting properties of the powders. 


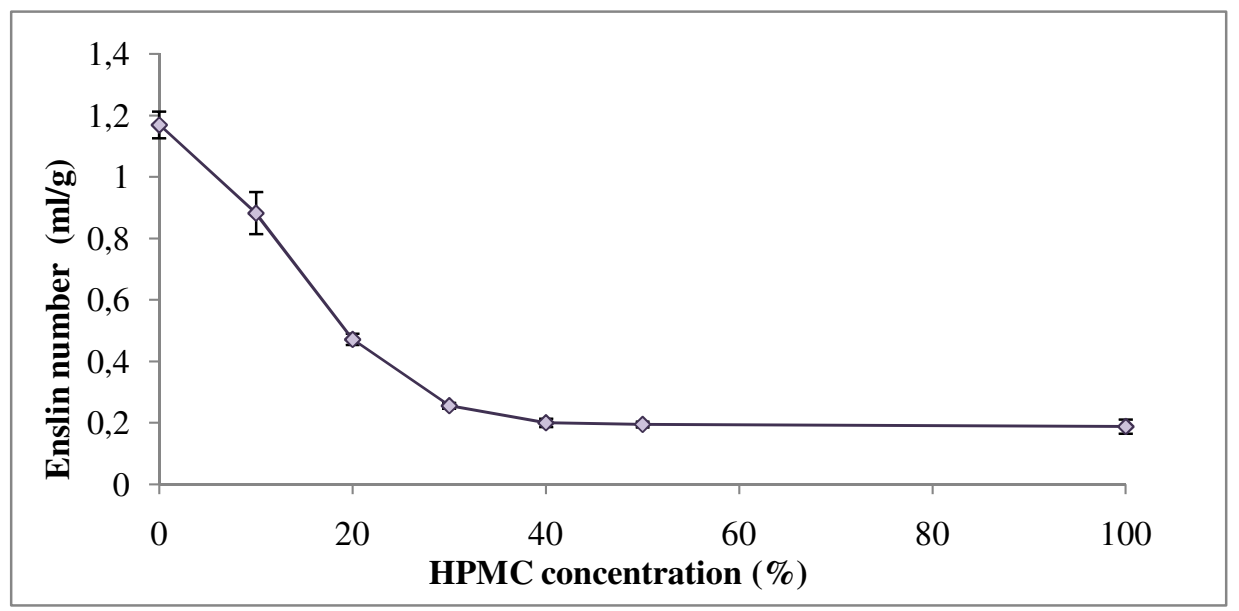

Figure 3. Erosion time and HPMC concentration

The characteristic water uptake time $\left(\mathrm{t}_{63.2 \%}\right)$ was the shortest for Mix0 (Table 3). The values of the shape parameters $(\beta)$ are $<1$ in every case, and thus the curves are saturation curves with a fast initial increase. The values of the scale parameter (a) increased with higher amounts of matrix former.

It can be concluded that not only the quantity of water, but also the speed of this process was the lowest for HPMC. This is demonstrated by the gel forming property of this material and the barrier function of this gel layer.

Table 3. Characteristic water uptake time of samples

\begin{tabular}{ccccc}
\hline Sample & $\mathbf{t}_{\mathbf{6 3 . 2} \%}(\mathbf{s})$ & $\boldsymbol{\beta}$ & $\mathbf{a}$ & $\mathbf{R}^{\mathbf{2}}$ value \\
\hline Mix0 & 7.26 & 0.8500 & 7.15 & 0.9992 \\
Mix10 & 9.07 & 0.8333 & 9.59 & 0.9991 \\
Mix20 & 8.47 & 0.8100 & 11.84 & 0.9903 \\
Mix30 & 24.08 & 0.7980 & 15.74 & 0.9979 \\
Mix40 & 24.00 & 0.7884 & 17.63 & 0.9872 \\
Mix50 & 48.25 & 0.7812 & 19.73 & 0.9892 \\
Mix100(HPMC) & 99.01 & 0.7885 & 25.26 & 0.9753 \\
\hline
\end{tabular}

\subsection{Erosion study of matrices}

In case of granules, disintegration study has a great importance because the API can liberate, absorb and affect the body after erosion of granules. Matrix compacts were produced from powder mixtures with a Korsch EK0 (Emil Korsch Maschinenfabrik, Berlin, Germany) instrumented eccentric tablet machine. Flat punches $10 \mathrm{~mm}$ in diameter, and upper compression force $5 \pm 1 \mathrm{kN}$ were used, additional excipients (lubricant and glidant) were not 
applied. The speed of compression was $36 \mathrm{tbl} / \mathrm{min}$, and the circumstances were: $26 \pm 2{ }^{\circ} \mathrm{C}$ and $55 \pm 5 \%$ RH.

The erosion of these tablets - the term dissolution is not correct for these systems because of the insoluble MCC - was evaluated with the disintegration tester (Erweka ZT 71, Erweka $\mathrm{GmbH}$, Heusenstamm, Germany) and method specified in the Pharmacopoeia. Distilled water was used as disintegrating liquid. Six parallel experiments were performed.

It can be seen from Table 4 that the change in erosion time was very relevant while the concentration of the matrix former was increasing. The values for the samples containing at least $40 \%$ of HPMC did not differ significantly from that for pure HPMC.

Table 4. Erosion times of compacts

\begin{tabular}{cc}
\hline Sample & Erosion time (min) \\
\hline Mix0 & $0.11 \pm 0.01$ \\
Mix10 & $1.33 \pm 0.18$ \\
Mix20 & $25.60 \pm 6.97$ \\
Mix30 & $65.71 \pm 6.94$ \\
Mix40 & $89.06 \pm 7.00$ \\
Mix50 & $92.92 \pm 8.43$ \\
Mix 100(HPMC) & $89.49 \pm 7.55$ \\
\hline
\end{tabular}

\subsubsection{Discussion}

A connection was detected between erosion times of the samples and Enslin numbers (Figure 4). An exponential decrease can be seen in the erosion time while the quantity of water taken up was increasing. The behavior of the polymer alone was very different from that of the matrix. The samples with $40 \%$ and $50 \%$ of HPMC exhibited very similar properties to those of pure HPMC. 


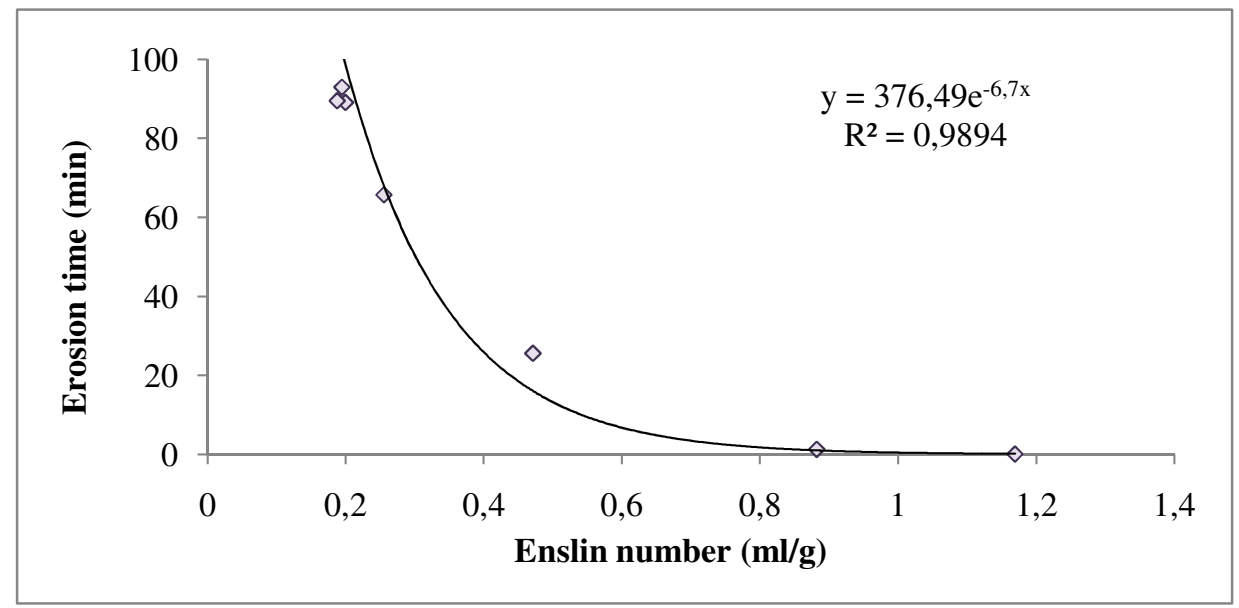

Figure 4. Comparison of Enslin numbers and erosion times of samples

The object of this study was the evaluation of the composition of products in which the effects of the matrix former were relevant, but its properties differed significantly from those of HPMC. This was chosen on the basis of the results of preformulation studies, which revealed that HPMC without other components (Mix100) is not appropriate for high-shear granulation. Adherence to the wall of the container and the impeller was detected because of the gel forming property and the adhesive behavior of the developed layer. The samples containing 30\% of HPMC (Mix30) were the most optimal; therefore they were used in the subsequent part of our study.

\subsubsection{Determination of the optimum quantity of granulating fluid}

The chosen powder mixture was granulated with different quantities of water in a highshear granulator (ProCepT 4M8 granulator, ProCepT nv, Zelzate, Belgium). Generally, the critical process data are mixer torque, product temperature, mixer- and chopper speed, liquid dosing speed- and volume. In this present study, most of them were analyzed. Granulating liquid was distilled water and the parameters during the experiments were the same, except for the quantity of water:

Speed of impeller: $750 \mathrm{rpm}$

Speed of chopper: $2500 \mathrm{rpm}$

Dosing speed of liquid: $10 \mathrm{~mL} / \mathrm{min}$

Kneading time: $1 \mathrm{~min}$

Weight of powder mixture: $150 \mathrm{~g}$ 
The quantities of liquid to $100 \mathrm{~g}$ powder mixture were $20 \mathrm{~g}$ (S1), $25 \mathrm{~g}$ (S2), $27.5 \mathrm{~g}$ (S3), $30 \mathrm{~g}$ (S4), $35 \mathrm{~g}$ (S5) or $40 \mathrm{~g}$ (S6). Granules were dried on trays at $40{ }^{\circ} \mathrm{C}$ for $24 \mathrm{~h}$.

\subsubsection{Size and size distributions}

Sizes and size distributions of the samples were evaluated with an analytical sieve series (Retsch GmbH, Haan, Germany). Mean particle size (D50) was determined with the sieving system software (Retsch EasySieve 2.0). D50 value of the granules continuously increased with increasing amount of water (Table 5). In case of samples prepared with $35 \mathrm{~g}$ water to $100 \mathrm{~g}$ powder, the amount of powder fraction was small and particle size was not too high either, so in the following experiments this amount of water was applied.

Table 5. Parameters of granules prepared with different quantities of water

\begin{tabular}{cccc}
\hline Sample & $\begin{array}{c}\text { Water/100 g } \\
\text { powder }(\mathbf{g})\end{array}$ & D50 $(\boldsymbol{\mu m})$ & $\begin{array}{c}\text { Ratio of particles } \\
<\mathbf{5 0 0} \boldsymbol{\mu m}(\boldsymbol{\%})\end{array}$ \\
\hline S1 & 20 & 461 & 54.3 \\
S2 & 25 & 607 & 44.9 \\
S3 & 27.5 & 660 & 41 \\
S4 & 30 & 789 & 34.3 \\
S5 & 35 & 974 & $\mathbf{1 6 . 5}$ \\
S6 & 40 & 1834 & 0.5 \\
\hline
\end{tabular}

\subsubsection{Optimization of the granulating process}

In this part of the study, the quantities of the powder mixture and the liquid remained the same but the technical parameters were changed (Table 6). A $2^{4}$ full factorial design was utilized to choose the relevant factors. Factorial design is a method that is often used to accelerate the solution of tasks. It can also be utilized to evaluate interactions which can arise during direct compression. This method has been applied in several branches of science and industry (such as food industry [89], environmental management [90], chemistry [91] and pharmaceutical technology [92]). The levels of the factors can be found in Table 6. The experiments were performed in randomized sequence.

Table 6. Levels of factors

\begin{tabular}{ccc}
\hline Factor & Low-level (-) & High-level $(+)$ \\
\hline Speed of chopper $\left(X_{1}\right)(\mathrm{rpm})$ & 1500 & 3500 \\
Speed of impeller $\left(X_{2}\right)(\mathrm{rpm})$ & 500 & 1000 \\
Dosing speed $\left(X_{3}\right)(\mathrm{mL} / \mathrm{min})$ & 5 & 15 \\
Kneading time $\left(X_{4}\right)(\mathrm{min})$ & 1 & 4 \\
\hline
\end{tabular}


The following approach, containing the interactions of factors, was used to determine the response surface and relative effect of factors (b):

$$
\begin{gathered}
y=b_{0}+b_{1} X_{1}+b_{2} X_{2}+b_{3} X_{3}+b_{4} X_{4}+b_{12} X_{1} X_{2}+b_{13} X_{1} X_{3}+b_{23} X_{2} X_{3}+b_{14} X_{1} X_{4}+b_{24} X_{2} X_{4}+ \\
b_{34} X_{3} X_{4}+b_{123} X_{1} X_{2} X_{3}+b_{234} X_{2} X_{3} X_{4}+b_{124} X_{1} X_{2} X_{4}+b_{134} X_{1} X_{3} X_{4}
\end{gathered}
$$

Statistica for Windows 7.1 AGA software (StatSoft, Inc., Tulsa, USA) was used for the calculations. During the mathematical evaluations, the confidence interval was $95 \%$, i.e. the differences were significant if $\mathrm{p}<0.05$.

The main objective of this study was to evaluate the effect of the operational parameters on the particle size. It can be seen in Table 7 that the D50 values of different charges varied between 917 and $1478 \mu \mathrm{m}$.

Table 7. Parameters of granules with different operational parameters

\begin{tabular}{ccccc}
\hline $\begin{array}{c}\mathbf{X}_{\mathbf{1}} \\
(\mathbf{r p m})\end{array}$ & $\begin{array}{c}\mathbf{X}_{\mathbf{2}} \\
(\mathbf{r p m})\end{array}$ & $\begin{array}{c}\mathbf{X}_{\mathbf{3}} \\
(\mathbf{m L} \mathbf{m i n})\end{array}$ & $\begin{array}{c}\mathbf{X}_{\mathbf{4}} \\
\mathbf{m i n})\end{array}$ & $\begin{array}{c}\mathbf{D 5 0} \\
(\boldsymbol{\mu m})\end{array}$ \\
\hline 3500 & 500 & 15 & 4 & 1222 \\
\hline 1500 & 500 & 5 & 1 & 1306 \\
1500 & 1000 & 15 & 1 & 918 \\
\hline 3500 & 1000 & 5 & 4 & 1232 \\
1500 & 500 & 15 & 1 & 1268 \\
\hline 1500 & 1000 & 15 & 4 & 976 \\
\hline 3500 & 1000 & 5 & 1 & 1306 \\
\hline 3500 & 1000 & 15 & 1 & $\mathbf{9 1 7}$ \\
\hline 1500 & 500 & 15 & 4 & 1306 \\
\hline 3500 & 1000 & 15 & 4 & 962 \\
\hline 3500 & 500 & 5 & 1 & 1284 \\
\hline 3500 & 500 & 5 & 4 & 1247 \\
\hline 1500 & 1000 & 5 & 1 & 1216 \\
\hline 1500 & 500 & 5 & 4 & 1333 \\
\hline 3500 & 500 & 15 & 1 & 1264 \\
\hline 1500 & 1000 & 5 & 4 & $\mathbf{1 4 7 8}$ \\
\hline
\end{tabular}

After the determination of the response surface, fitting was very good $\left(\mathrm{R}^{2}=0.9829\right)$ for D50 value, but there was no significant factor (Table 8). The largest effect was observed for $\mathrm{X}_{3}$ (dosing speed). Since the sign of this factor is negative, increase of dosing speed caused a decrease in particle size. 


\begin{tabular}{cc}
\hline Coefficient & Value for D50 \\
\hline$b_{0}$ & 1202.19 \\
$b_{1}$ & -22.94 \\
$b_{2}$ & -76.56 \\
$b_{3}$ & -98.06 \\
$b_{4}$ & 17.31 \\
$b_{12}$ & 1.56 \\
$b_{13}$ & 10.06 \\
$b_{14}$ & -30.81 \\
$b_{23}$ & -84.31 \\
$b_{24}$ & 19.06 \\
$b_{34}$ & -4.94 \\
$b_{123}$ & 7.56 \\
$b_{124}$ & -12.81 \\
$b_{134}$ & 19.19 \\
$b_{234}$ & -5.69 \\
\hline & *significant
\end{tabular}

\subsubsection{Temperature elevation during granulation}

The high-speed moving of the parts of a small-scale high-shear granulator - impeller and chopper - can cause a relevant increase in the temperature of the powder/granules. This parameter can therefore be an indirect factor during the optimization. Its importance is emphasized by the temperature-sensitive nature of the solubility of the components. Both the rate of dissolution and the quantity of materials dissolved can depend on temperature. Hence the composition of the solution formed during granulation and after drying in the binder film can be different. Since the exact, direct measurement of the components in the fluid formed around the solid particles and inside the wet granules seems to be impossible, it is reasonable to study the properties of free films formed from different ratios of the soluble components [93].

Since at the applied ProCepT apparatus there was an opportunity to continuously follow the values of the control parameters during granulation, temperature change was easily detected (Table 9). The temperature increase during the granulation process also exhibited a great variance $\left(4.8-18.6^{\circ} \mathrm{C}\right)$. The variation in this parameter is significant as temperature elevation increases the solubility of lactose, but reduces that of HPMC. For example, the solubility of lactose is 1 part in 4.63 parts of water at $20{ }^{\circ} \mathrm{C}$ and 1 part in 2.04 parts of water at $50{ }^{\circ} \mathrm{C}$ [94]. The concentration of the saturated solution is therefore $17.8 \%$ at $20{ }^{\circ} \mathrm{C}$ and $32.9 \%$ at $50{ }^{\circ} \mathrm{C}$. 
Table 9. Temperature elevation

\begin{tabular}{ccccc}
\hline $\mathbf{X}_{\mathbf{1}}(\mathbf{r p m})$ & $\mathbf{X}_{\mathbf{2}}(\mathbf{r p m})$ & $\mathbf{X}_{\mathbf{3}}(\mathbf{m L} \mathbf{m i n})$ & $\mathbf{X}_{\mathbf{4}}(\mathbf{m i n})$ & $\Delta \mathbf{H}\left({ }^{\mathbf{0}} \mathbf{C}\right)$ \\
\hline 3500 & 500 & 15 & 4 & 7,3 \\
1500 & 500 & 5 & 1 & 7,7 \\
1500 & 1000 & 15 & 1 & 7,5 \\
3500 & 1000 & 5 & 4 & $\mathbf{1 8 , 6}$ \\
1500 & 500 & 15 & 1 & $\mathbf{4 , 8}$ \\
1500 & 1000 & 15 & 4 & 9,7 \\
3500 & 1000 & 5 & 1 & 13,8 \\
3500 & 1000 & 15 & 1 & 8,0 \\
1500 & 500 & 15 & 4 & 5,6 \\
3500 & 1000 & 15 & 4 & 10,1 \\
3500 & 500 & 5 & 1 & 6,1 \\
3500 & 500 & 5 & 4 & 8,2 \\
1500 & 1000 & 5 & 1 & 13,0 \\
1500 & 500 & 5 & 4 & 7,0 \\
3500 & 500 & 15 & 1 & 4,8 \\
1500 & 1000 & 5 & 4 & 15,5 \\
\hline
\end{tabular}

The fitting of the response surface for the temperature elevation resulted in a model with $R^{2}=0.982$ and two significant factors $(p<0.05)$. Increase of the impeller speed significantly enhanced temperature elevation, and it was also increased by reduction of the dosing speed. It was clear from the evaluation of all the factors that an increased process time caused increases in particle size and temperature of the sample (Table 10).

Table 10: Effect of factors on temperature elevation

\begin{tabular}{cc}
\hline Coefficient & Value for $\mathbf{\Delta H}$ \\
\hline$b_{0}$ & 9,20 \\
$b_{1}$ & 0,83 \\
$b_{2}$ & $\mathbf{5 , 5 3 *}$ \\
$b_{3}$ & $\mathbf{- 3 , 9 5 *}$ \\
$b_{4}$ & 1,98 \\
$b_{12}$ & 0,50 \\
$b_{13}, 0,18$ \\
$b_{14}$ & 0,90 \\
$b_{23}$ & $-2,33$ \\
$b_{24}$ & 0,80 \\
\hline$b_{34}$ & $-0,08$ \\
$b_{123}$ & $-0,70$ \\
\hline$b_{124}$ & $-0,23$ \\
$b_{134}$ & $-0,50$ \\
\hline
\end{tabular}


Film bridges developing during drying from HPMC act as binder between the granules, it is a common mechanism in pharmaceutical wet granulations [4]. However, dissolution of lactose should also be taken into account during granulation. As it is emphasized above, it may be presumed that the different temperature values may modify the ratio of materials dissolved, thus the composition and properties of developing film bridges is also to be different.

Components dissolved may be in amorphous or crystalline form after drying. Study of the composition and crystalline state of these individual small bridges in the granules is difficult, but an understanding of their formation is critical for optimization of the granulation process. The significance of such evaluations is highlighted by the well-known phenomenon that an amorphous form can change during storage and can indicate stability problems [95]. On the basis of that, these phenomena were investigated in details.

\subsection{Evaluation of the films}

Different samples were prepared for the thermoanalytical tests on the free film. Aqueous solutions containing various ratios of HPMC and lactose were produced (Table 11). They were poured into teflon dishes, and the solutions were then dried under the same conditions at $40 \pm 2{ }^{\circ} \mathrm{C}$ for $24 \mathrm{~h}$. The dried films were detached from the surface before the experiments and stored in a hermetically closed container.

Table 11. Composition of films

\begin{tabular}{ccccc}
\hline Sample & $\begin{array}{c}\text { HPMC } \\
\text { content }(\boldsymbol{\%})\end{array}$ & $\begin{array}{c}\text { Lactose } \\
\text { content }(\boldsymbol{\%})\end{array}$ & $\begin{array}{c}\text { HPMC/lactose } \\
\text { ratio }\end{array}$ & $\begin{array}{c}\text { Water } \\
\text { content }(\boldsymbol{\%})\end{array}$ \\
\hline Film1 & 5 & 0 & - & 95 \\
Film2 & 5 & 1 & 5 & 94 \\
Film3 & 5 & 2 & 2,5 & 93 \\
Film4 & 5 & 3 & 1,67 & 93 \\
Film5 & 5 & 4 & 1,25 & 91 \\
\hline
\end{tabular}

\section{a) Differential scanning calorimerty (DSC) analysis}

Important effects, such as interactions and properties in pharmaceutical technology can be investigated by DSC methods [96, 97]. DSCs are used extensively in the pharmaceutical industry to determine the melting points [98], purity, and glass transition temperatures [99] of materials. This method can be used to differentiate crystalline and amorphous materials and to determine the amorphous/crystalline fraction of a sample [100]. 
DSC examinations were carried out with a Mettler-Toledo DSC 821e (Mettler-Toledo $\mathrm{GmbH}$, Switzerland) instrument with a dynamic method in the interval $25-300{ }^{\circ} \mathrm{C}$, at a heating rate of $10{ }^{\circ} \mathrm{C} / \mathrm{min}$. Argon was used as purge gas. Three parallel experiments were performed.

The starting components were studied first. A characteristic thermogram was observed for lactose monohydrate (Figure 5). There was an endothermic peak at about $150{ }^{\circ} \mathrm{C}$; this reflected the loss of crystalline water [101]. The other peak related to the melting of lactose. Above this temperature, the lactose decomposed. The DSC curve of the HPMC in this range was free from characteristic peaks. A wide endothermic peak at $100{ }^{\circ} \mathrm{C}$ can be explained by the loss of mechanically bounded water. A slight shifting of baseline was detected at higher temperature. It was the $T_{\mathrm{g}}$ of polymer.

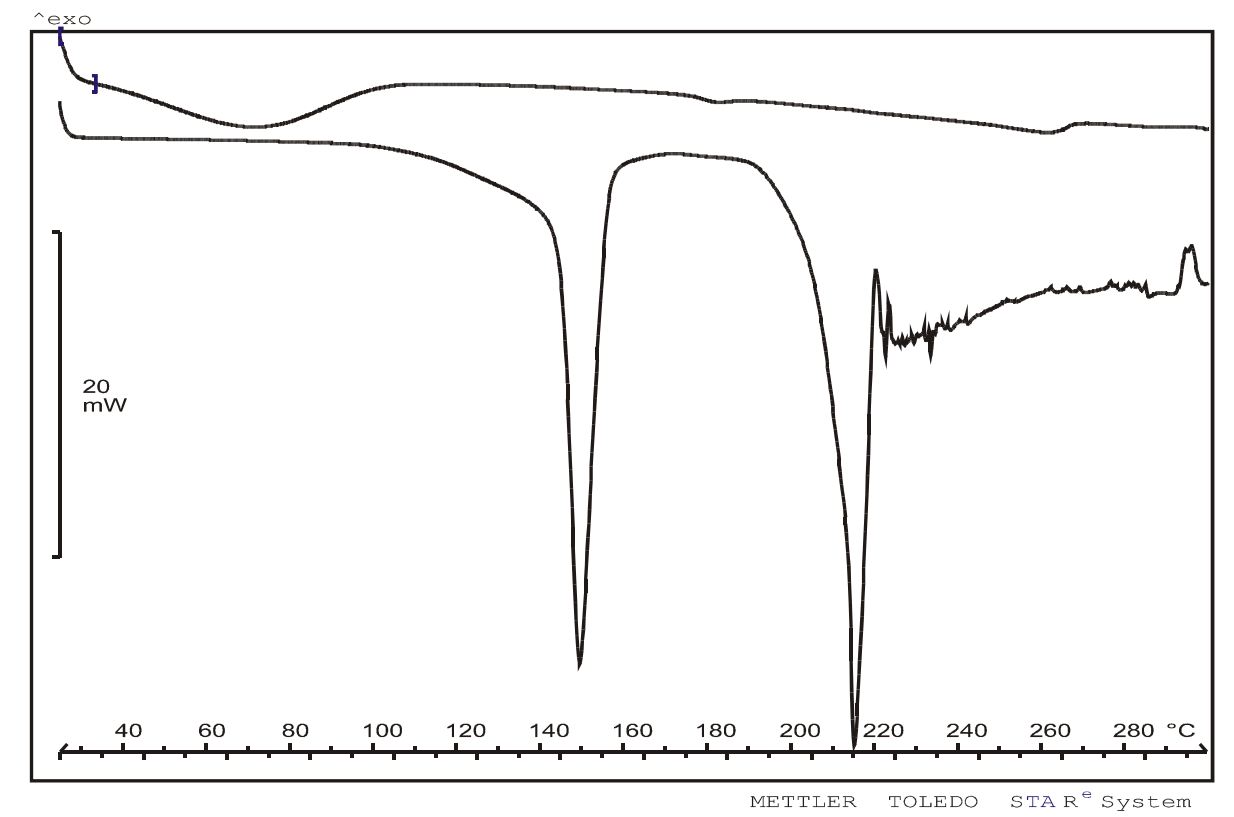

Figure 5. DSC plot of HPMC (upper curve) and lactose monohydrate (lower curve).

DSC experiments indicated similar behavior for all films. The curves of Film1 and Film5 are presented in Figure 6. The sharp characteristic peaks of lactose disappeared, but no obvious endothermic phenomenon was detected at around $210^{\circ} \mathrm{C}$ for Film5. Thus, the crystalline state of the lactose had evidently been lost. 


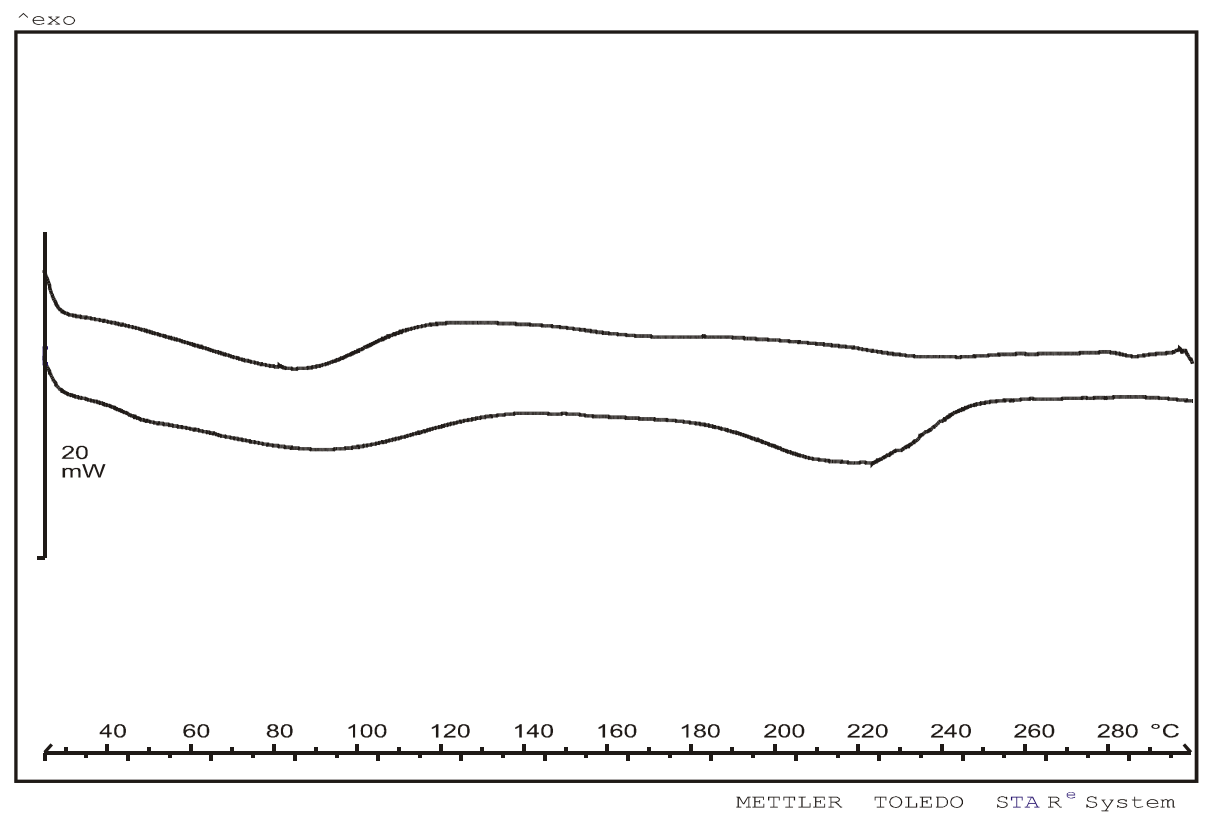

Figure 6. DSC plots of F1 (upper curve) and F5 (lower curve).

\section{b) Thermomechanical analysis (TMA)}

The technique of TMA is one of the major tools that is used in the assignment of glass transition temperatures $\left(T_{\mathrm{g}}\right)$. By definition, TMA is a technique in which the deformation of the sample under non-oscillatory stress is monitored against time or temperature while the temperature of the sample, in a specified atmosphere, is programmed [102-104]. The stress may be applied in compression, tension, flexure or torsion.

For a more accurate evaluation of the behavior of the $T_{\mathrm{g}}$ of polymer films, TMA was performed with a Mettler Toledo TMA 40 (Mettler-Toledo GmbH, Switzerland) apparatus. The heating method was dynamic in the interval $20-200{ }^{\circ} \mathrm{C}$, and the heating rate was $10{ }^{\circ} \mathrm{C} / \mathrm{min}$. $T_{\mathrm{g}}$ was studied with STAR software. The measurements were made in triplicate.

The TMA curve of HPMC exhibited a typical step relating to the glass transition of amorphous material (Figure 7). At temperatures below $T_{\mathrm{g}}$, the plot was linear. Deviation from linearity occurred as $T_{\mathrm{g}}$ was approached (onset temperature). As the temperature was increased further, the profile again became linear, indicating complete conversion to the rubbery phase. This process can be regarded as a shifting of the baseline. 


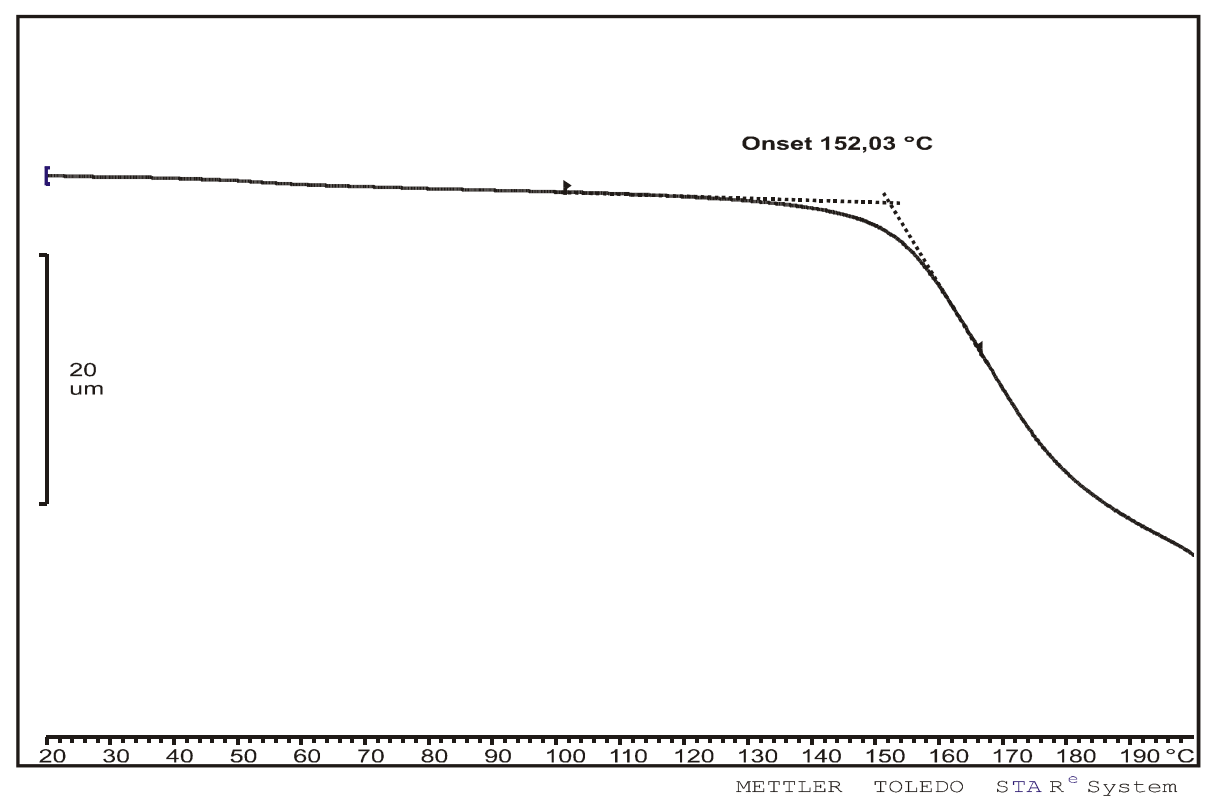

Figure 7. TMA plot of Film1

A change in composition altered the TMA curve of the film (Figures 8 and 9). It can be seen that a second $T_{\mathrm{g}}$ appeared for Film4 and Film5. The temperatures of onset of $T_{\mathrm{g}}$ are listed in Table 12. A decrease in the $T_{\mathrm{g}}$ of HPMC was detected for Film2 and Film3. Their values increased when the second step appeared for Film4, and decreased for Film5. These results can be interpreted in terms of changes in the structure of the film. For Film2 and Film3, the macromolecules and the lactose can interact, and the properties of the film then change. For Film4 and Film5, besides such interactions, a new amorphous phase with a $T_{\mathrm{g}}$ appeared. It is known from the literature that the $T_{\mathrm{g}}$ of amorphous lactose is $100-120^{\circ} \mathrm{C}$, depending on the methods and conditions [105-107]. Hence, the second step probably relates to a separate amorphous lactose phase. It is well-known that the proportion of ordered and amorphous regions determines the mechanical properties of a macromolecular film [108]. The different phases can be detected in the film, as they induce inhomogeneity in it. It is also known that amorphous materials are less stable than crystalline ones and the stabilization of amorphous materials is very difficult [109]. 


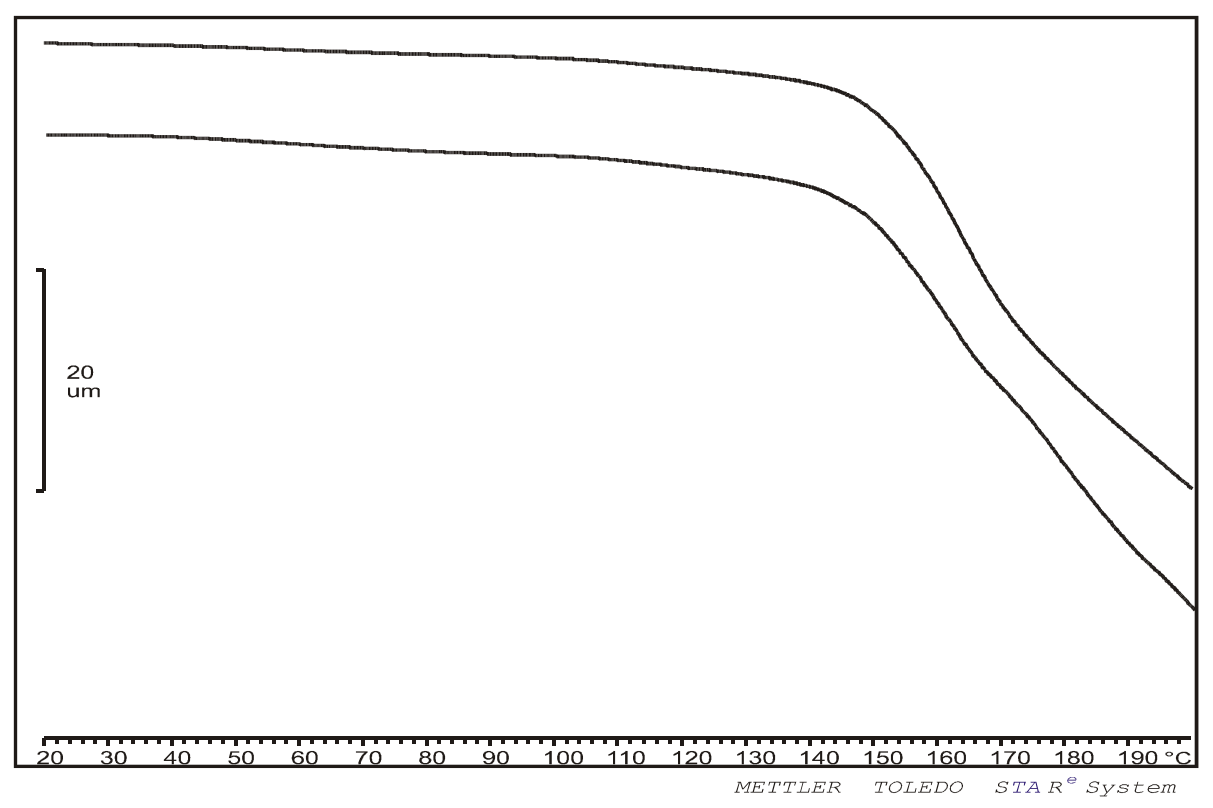

Figure 8. TMA plots of Film2 (upper curve) and Film3 (lower curve).

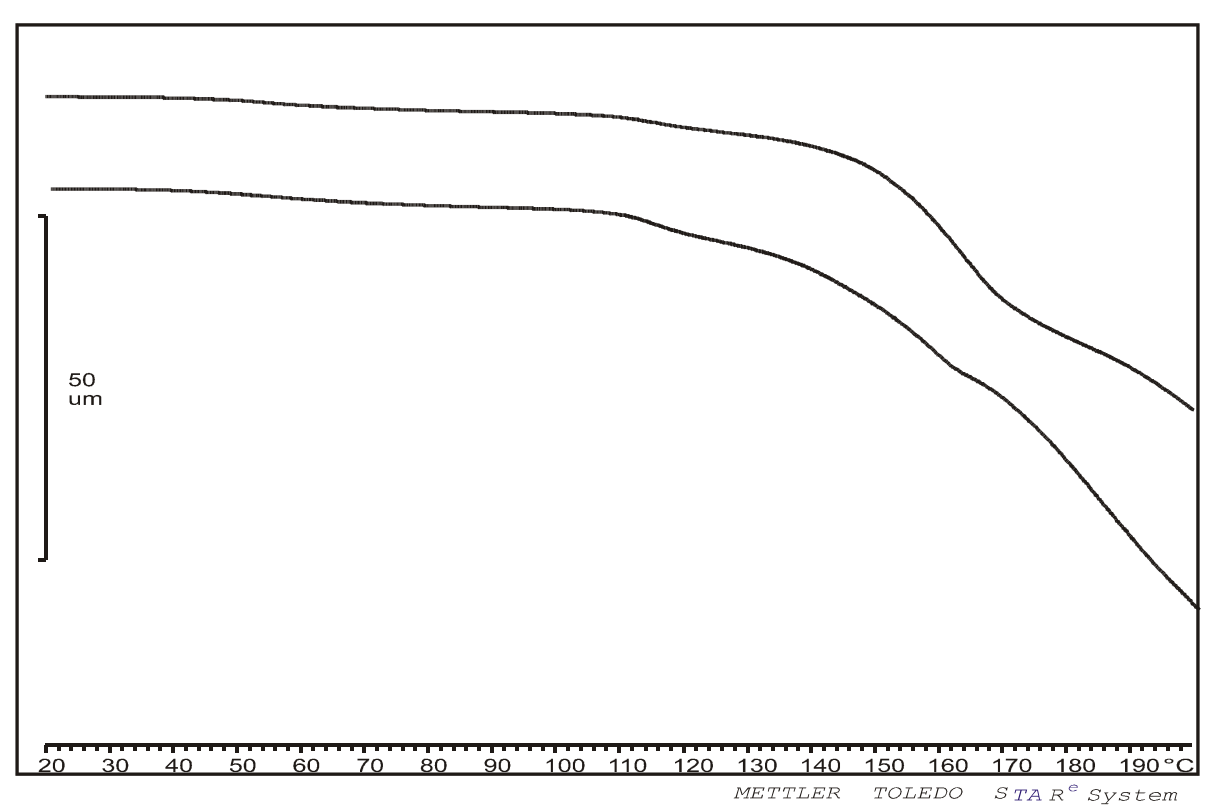

Figure 9. TMA plots of Film4 (upper curve) and Film5 (lower curve).

Table 12. Temperatures of onset of glass transition $(n=3)$

\begin{tabular}{ccc}
\hline Sample & $\mathbf{T}_{\mathbf{g}} \mathbf{1}\left({ }^{\circ} \mathbf{C}\right)$ & $\mathbf{T}_{\mathbf{g}} \mathbf{2}\left({ }^{\circ} \mathbf{C}\right)$ \\
\hline Film1 & $152.9 \pm 1.0$ & - \\
Film2 & $150.4 \pm 1.2$ & - \\
Film3 & $147.1 \pm 0.6$ & - \\
Film4 & $150.9 \pm 0.8$ & $108.3 \pm 0.2$ \\
Film5 & $143.3 \pm 0.9$ & $108.6 \pm 0.5$ \\
\hline
\end{tabular}




\subsection{X-ray diffraction (XRD) testing}

As the quality assurance requirements for one industry are not necessarily those of another, a characterization technique which can be tailored to the needs of a particular industry is desirable. One technique which has proven to be useful in a variety of single crystal inspection applications is X-ray diffraction topography $[110,111]$. XRD is widely used to determine the degree of crystallinity of pharmaceuticals $[112,113]$.

A Bruker D8 Advance powder diffractometer (Bruker-AXS; Karlsruhe, Germany) was used for these tests. The non-pulverized samples were measured in transmission mode between Mylar foils $(3.6 \mu \mathrm{m})$, the following conditions being applied at room temperature. Radiation: $\operatorname{CuK} \alpha 1(\lambda=1.54060 \AA)$ and $\operatorname{CuK} \alpha 2(\lambda=1.54439 \AA)$. The attachments were a Gobel mirror, a Soller slit, and a 9-position sample changer used in transmission mode. The voltage was $40 \mathrm{kV}$, the current was $30 \mathrm{~mA}$, and measurements involved a $\Theta / \Theta$ scan of 4-35.00॰2 $\Theta$, with a step size of $0.04 \circ 2 \Theta$.

The crystalline state of lactose and the amorphous properties of HPMC can be seen from the curves of the starting components (Figures 10 and 11).

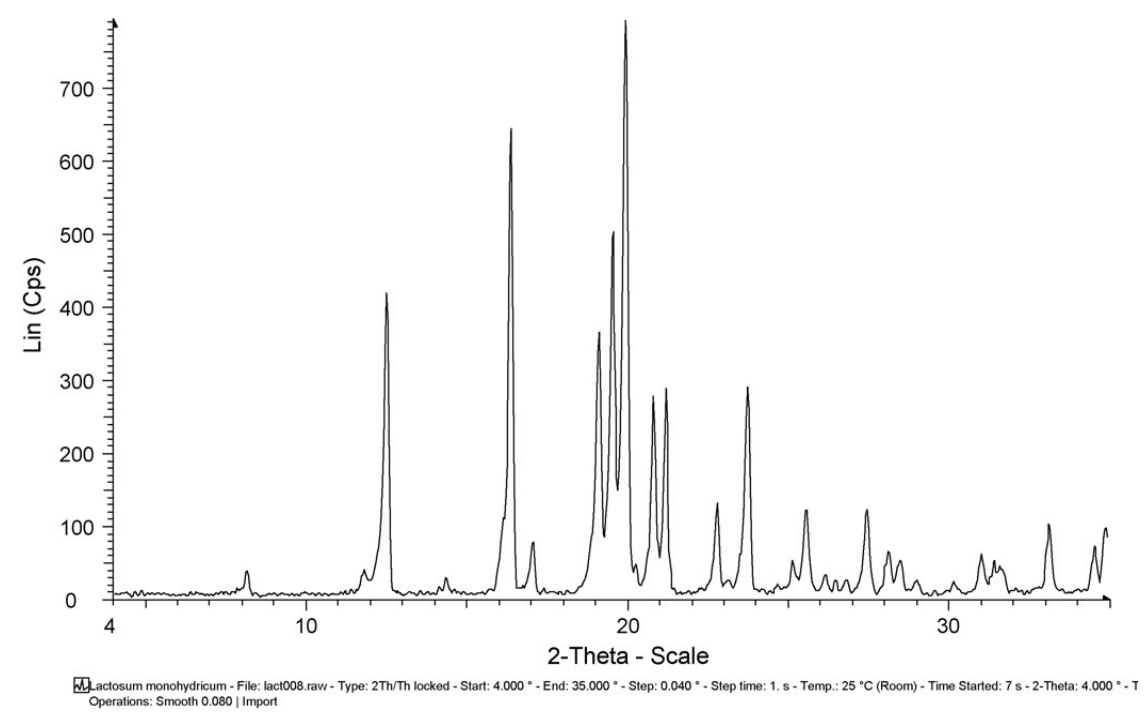

Figure 10. XRD record for lactose monohydrate 


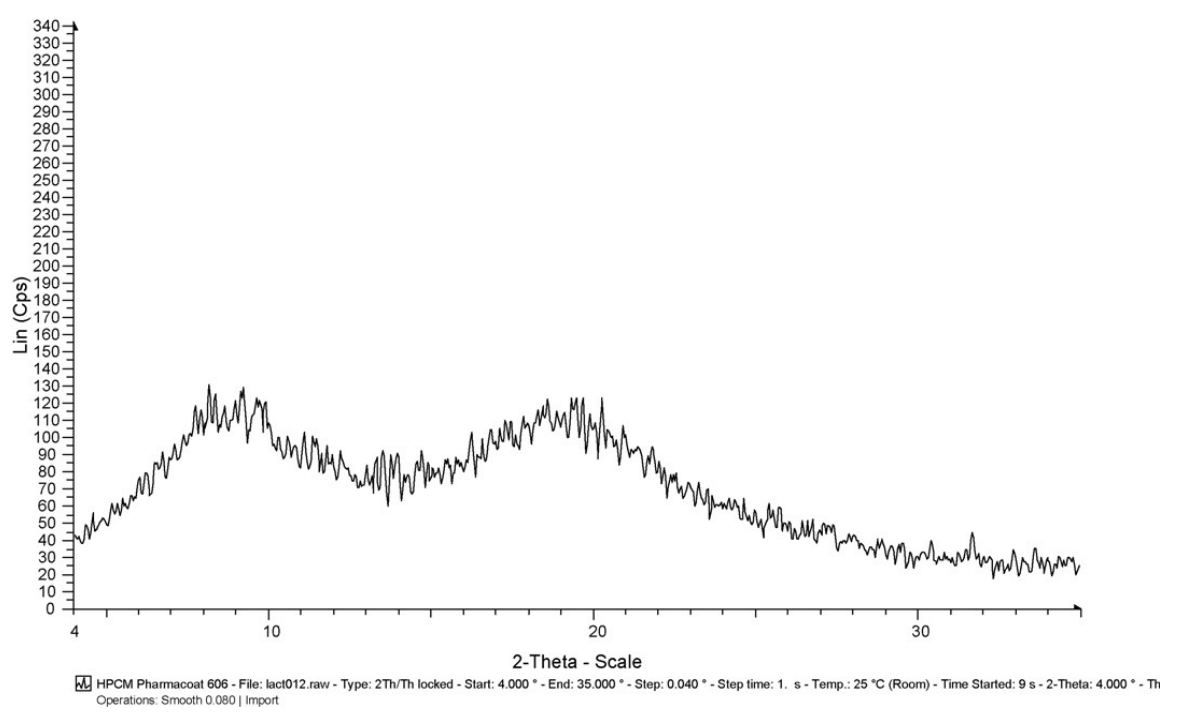

Figure 11. XRD record for HPMC.

The XRD curves of the films are typical for amorphous materials (Figures 12 and 13). It can be concluded that peaks typical for crystalline lactose were not detected even in samples with higher lactose content.

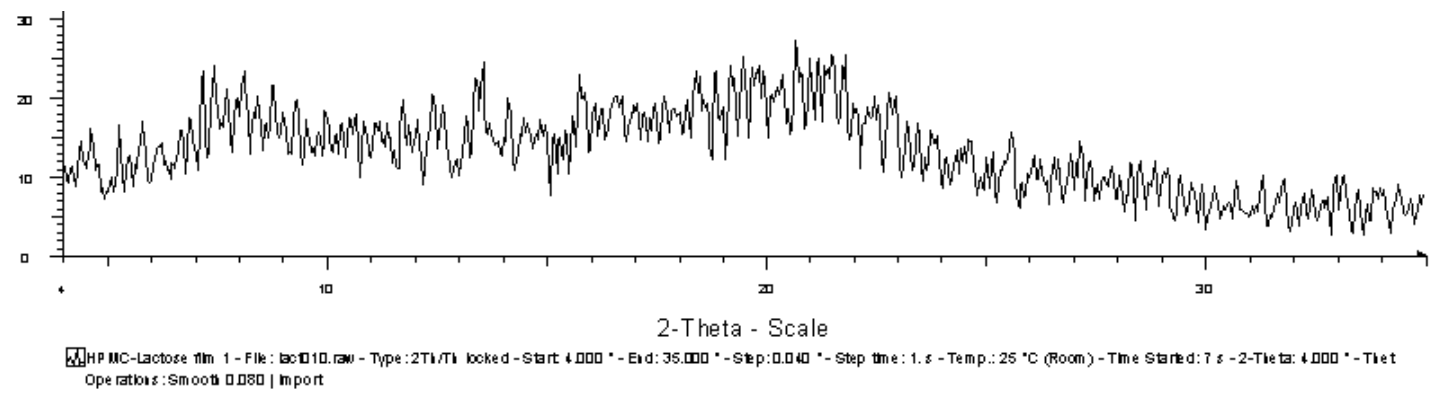

Figure 12. XRD record for Film1

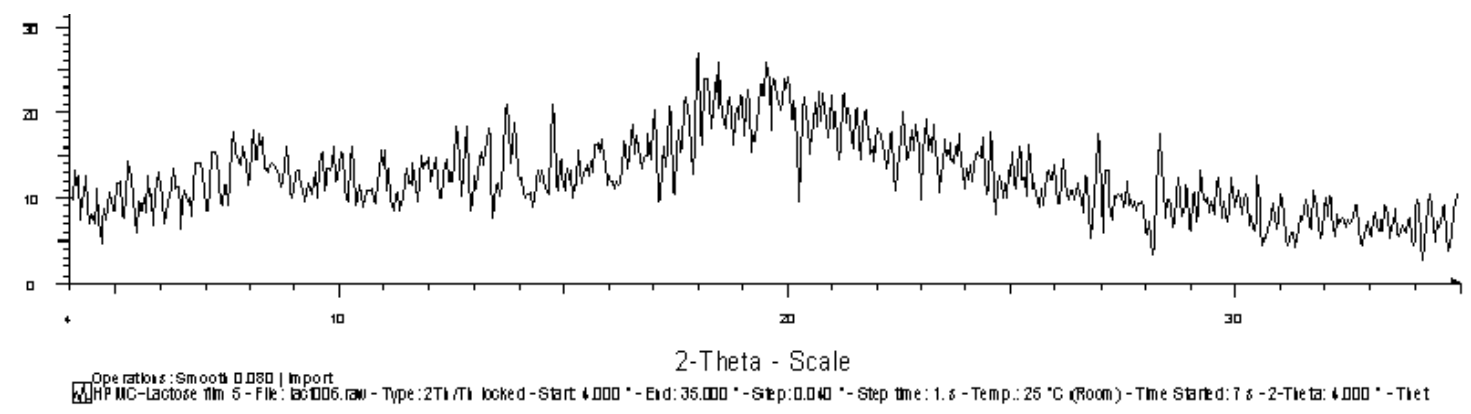

Figure 13. XRD record for Film5 
The individual amorphous phase of lactose changed in crystallinity during long storage (stored in a hermetically closed container at room temperature for 12 months). It was explained by X-ray diffraction study (Figure 14). Samples with two $T_{\mathrm{g}}$ (Film 4 and Film 5) exhibited characteristic peaks after the storage. In contrary, the samples without $T_{\mathrm{g}}$ (Films 1, 2 and 3) at around $110{ }^{\circ} \mathrm{C}$ did not show alteration. It can be concluded that the separate amorphous phase was partially recrystallized during the long-term storage, which can induce stability problems of product.

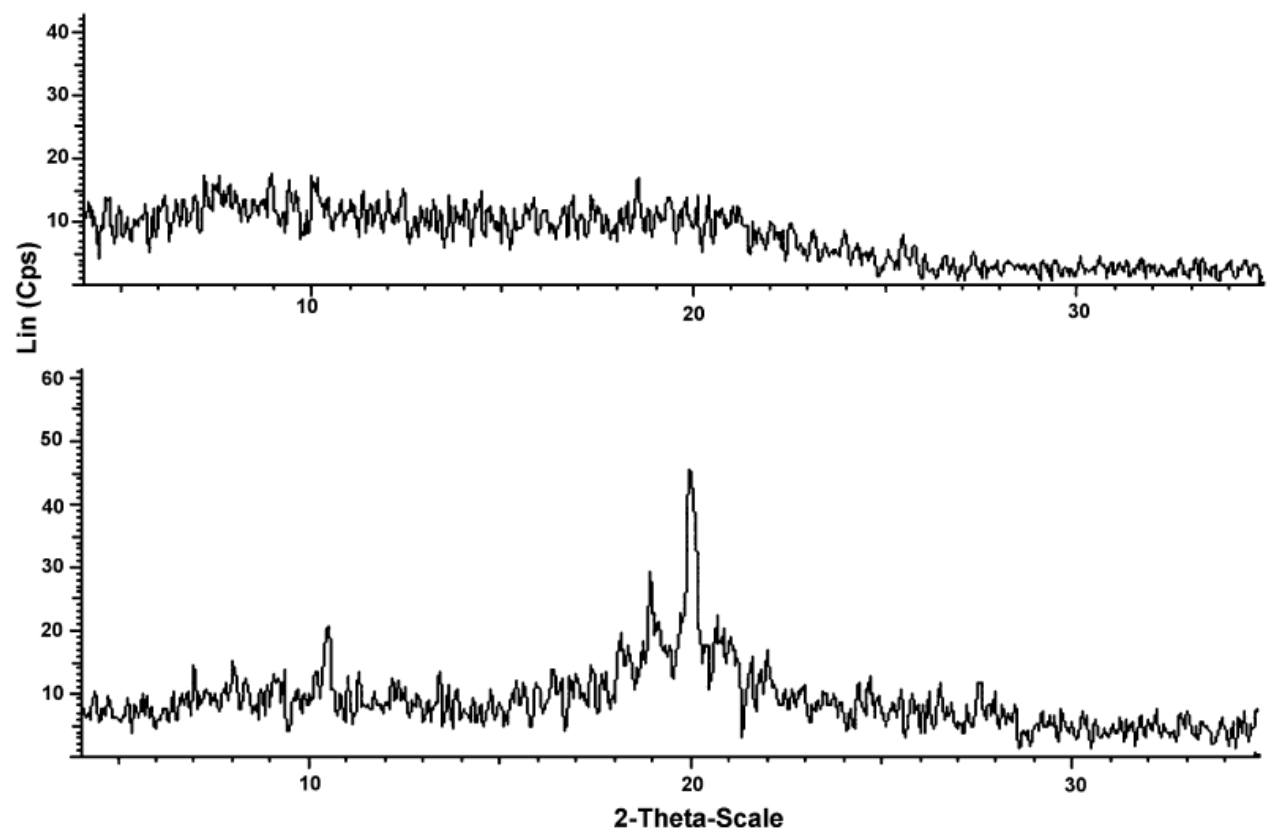

Figure 14. XRD records of stored Film1 (upper curve) and Film5 (lower curve).

\subsubsection{Conclusion}

Not only the particle size of the granules, but also the temperature of the powder mixture changed considerably during granulation at different operational parameters. The temperature increase was an indirect factor which can influence the dissolution of the powder mixture during granulation. At higher temperatures, a higher proportion of lactose and less HPMC are dissolved. The significant factors causing temperature increase were the impeller speed and the dosing speed. Alteration of the batch size can induce a relevant change in the temperature increase.

The crystalline behavior of lactose disappeared in films containing lactose and HPMC, as confirmed by DSC and XRD measurements. TMA indicated that an increase of the proportion of lactose in the film decreased the $T_{\mathrm{g}}$ of the film. This can be ascribed to the interaction of the components. At a lactose:HPMC ratio of 3:5, a second glass transition appeared. It points 
to the formation of a separate amorphous phase of lactose. Its crystallinity was changed during the storage.

In addition, it may be stated that evaluation of the temperature increase during granulation is necessary, since the small-scale granulation procedure can induce a dramatic change in this parameter. This should be kept in mind before prediction of the parameters applied for the granulation scale-up. Direct study of the composition of every individual binder bridge formed from soluble materials in the granules is impossible, but their indirect evaluation can be useful. These data provide additional information towards an understanding of granule formation in a small-scale high-shear granulator.

Finally, it can be concluded that testing of the wetting properties is necessary for the determination of the best composition and the conditions for the preparation of a matrix system. The effect of operational factors can be predicted from the results of such preformulation studies. 


\subsection{Part II.}

\subsubsection{Preparation of matrix granules containing lactic acid}

The aim of this part was to study the applicability of the prepared solid matrix system for the formulation of long-acting tablets containing LA. Different aqueous solutions of LA were used as granulating liquids. The effect of LA concentration on the $\mathrm{pH}$-decreasing effect of the tablets was also evaluated.

\subsubsection{Composition of powder mixtures}

The previous part of the study indicated that the optimum concentration of HPMC was $30 \%$. The quantity of MCC and $\alpha$-lactose monohydrate was $35-35 \%$.

\subsubsection{Methods}

\subsection{Preparation and study of granules}

Granules were prepared in the above mentioned ProCepT granulator. In accordance with our previous results, the quantity of liquid was $35 \mathrm{~g}$ to $100 \mathrm{~g}$ of powder mixture. The composition of granulating fluid was changed (Table 13). The operational parameters were as follows:

Impeller speed $500 \mathrm{rpm}$

Chopper speed: $3500 \mathrm{rpm}$

Liquid dosing speed: $15 \mathrm{~mL} / \mathrm{min}$

Kneading time: $4 \min$

Mass of powder mixture: $150 \mathrm{~g}$

Granules were dried on trays at $40^{\circ} \mathrm{C}$ for $24 \mathrm{~h}$.

Table 13. Composition of granulating fluid

\begin{tabular}{ccc}
\hline Sample & Concentration of LA (\%) & $\mathbf{p H}$ \\
\hline SO & 0 & 4.97 \\
$S 1$ & 3 & 2.17 \\
$S 2$ & 6 & 1.99 \\
$S 3$ & 9 & 1.88 \\
$S 4$ & 12 & 1.81 \\
S5 & 15 & 1.72 \\
\hline
\end{tabular}

Sizes and size distributions of the granules were assessed after drying. The analytical sieve series and the sieving system software mentioned above (see 4.3.2.1) were used. 
Friability was applied to determine the mechanical properties of the granules. The percentage weight loss after tumbling is called friability [2]. A special friability test was used for this measurement which was developed in the Department of Pharmaceutical Technology [114]. $3.0 \mathrm{~g}$ of granules $(>1.2 \mathrm{~mm})$ was placed into a $60 \mathrm{~mL}$ bottle, together with 3 stainless steel balls $10 \mathrm{~mm}$ in diameter. The bottle was then placed into a rotating shaker mixer (Turbula, Willy A. Bachofen Masinenfabrik, Basel, Schwitzerland) and it was running with $50 \mathrm{rpm}$ for $5 \mathrm{~min}$. The abraded samples were sieved on a $400 \mu \mathrm{m}$ sieve. The measurements were made in triplicate.

Size and size distribution of the prepared matrix granules were very similar for all samples (Table 14). The presence of LA in the granulating fluid did not alter the particle size distribution of the products. The mechanical properties of the products were not changed relevantly either, the friability was $<5 \%$ in every case and no clear tendency could be observed.

Table 14. Parameters of granules

\begin{tabular}{ccc}
\hline Sample & D50 $(\mathbf{m m})$ & Friability $(\%)$ \\
\hline SO & 1.222 & $3.30 \pm 0.15$ \\
S1 & 1.245 & $2.99 \pm 0.16$ \\
S2 & 1.178 & $2.73 \pm 0.09$ \\
S3 & 0.995 & $2.94 \pm 0.07$ \\
S4 & 1.256 & $4.06 \pm 0.03$ \\
S5 & 1.289 & $3.40 \pm 0.12$ \\
\hline
\end{tabular}

\subsection{Preparation of matrix tablets}

Tablets were prepared with a hydraulic press (Specac Ltd., Graseby, UK). Round and flat punches $13 \mathrm{~mm}$ in diameter were used. $1 \mathrm{~g}$ of granules was pressurized at $5 \times 10^{8} \mathrm{~Pa}$ and the comprimates were stored in a desiccator before the dissolution test.

\subsection{In vitro evaluation of released lactic acid}

The in vitro dissolution test was also a special one because the quantity of vaginal fluid is so low that the prescribed test for conventional oral tablets in the $\mathrm{Ph}$. Eur. would not have given accurate information. In our modified test a tablet was placed into a $25 \mathrm{~mL}$ glass beaker and immersed into a water bath which ensured $37 \pm 1^{\circ} \mathrm{C} .4 .00 \mathrm{~mL}$ of phosphate buffer (Ph. Eur.) was used as dissolution medium, which is equivalent with the $\mathrm{pH}$ of vaginal fluid $(\mathrm{pH}=4.56 \pm 0.01)$. The test liquid was removed after every hour and replaced with $4.00 \mathrm{~mL}$ fresh buffer. The testing period was $8 \mathrm{~h}$. The $\mathrm{pH}$ of the liquid was measured with a $\mathrm{pH}$ tester 
(WinLab pH-Meter, Windaus-Labortechnik GmbH \& Co. KG, Clausthal-Zellerfeld, Germany). The dissolution of the acidic component was followed via the change in $\mathrm{H}^{+}$in the dissolution medium. Three parallel tests were performed.

Each of the samples exhibited very similar behavior in the dissolution medium. Swelling of the tablets and erosion of the samples could be detected in the liquid (Figure 15). It can be seen from the pictures that the shape constantly changed during the test. The main alteration could be seen after $4 \mathrm{~h}$. Before this point, a mainly cylindrical shape was detected, but after this time the edges of the comprimates had disappeared because of the constant erosion. After hemisphere formation, no further change in shape was detected.

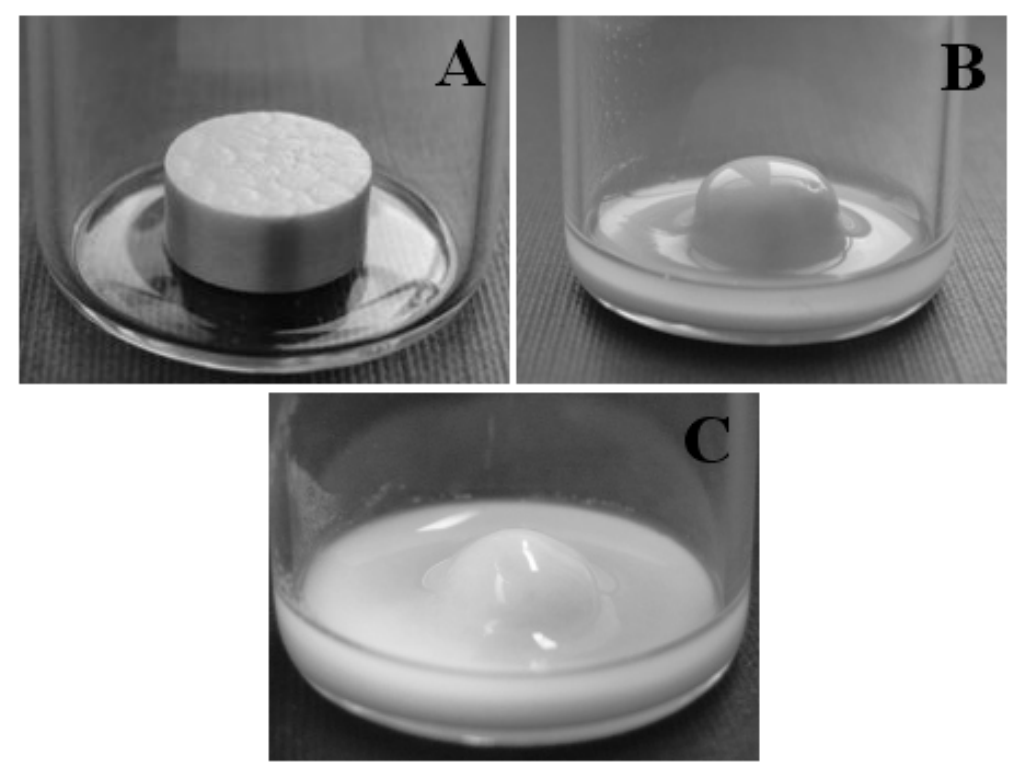

Figure 15. Change in tablets during dissolution test

(A - starting tablet, B-after 4 h, C-after 8 h)

At the end of the dissolution, dry granules could be observed in the inner structure of the sample (Figure 16).
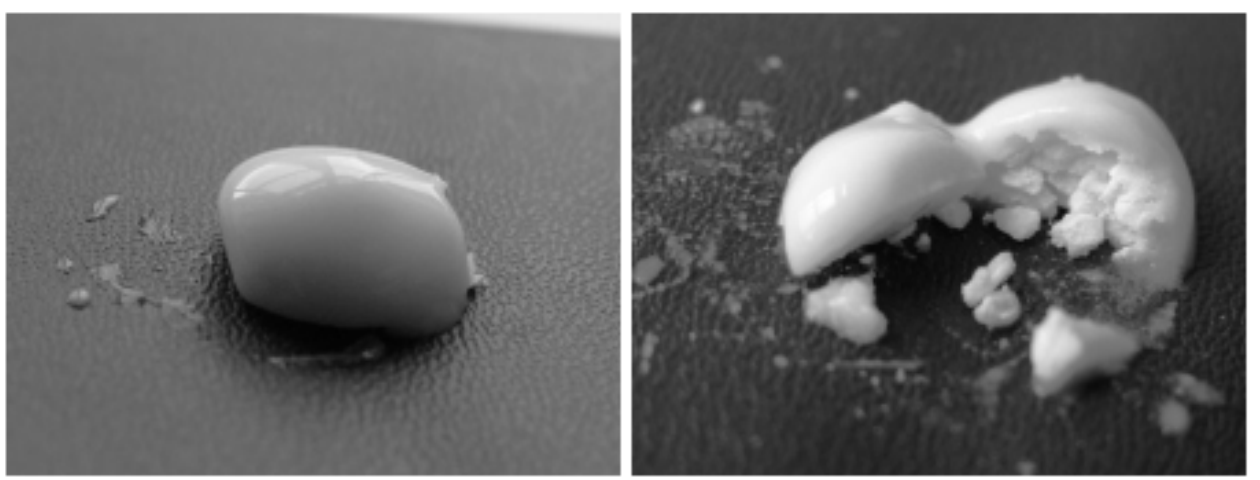

Figure 16. Inner structure of the tablet after $8 \mathrm{~h}$ 
It can be seen from the results of the dissolution tests that the sample without LA (S0) did not change the $\mathrm{pH}$ of test liquid (Table 15). However, lower $\mathrm{pH}$ values were clearly detected for the samples containing larger amounts of LA. The $\mathrm{pH}$-decreasing effect of the tablets diminished during every hour.

Table 15. pH of the dissolution medium

\begin{tabular}{ccccccc}
\hline Time (h) & S0 & S1 & S2 & S3 & S4 & S5 \\
\hline 1 & $4.59 \pm 0.07$ & $3.52 \pm 0.01$ & $3.31 \pm 0.03$ & $3.33 \pm 0.01$ & $3.24 \pm 0.02$ & $3.22 \pm 0.04$ \\
2 & $4.58 \pm 0.04$ & $3.60 \pm 0.06$ & $3.47 \pm 0.04$ & $3.41 \pm 0.02$ & $3.37 \pm 0.03$ & $3.32 \pm 0.02$ \\
3 & $4.56 \pm 0.02$ & $3.62 \pm 0.04$ & $3.52 \pm 0.03$ & $3.49 \pm 0.03$ & $3.41 \pm 0.01$ & $3.36 \pm 0.02$ \\
4 & $4.56 \pm 0.01$ & $3.69 \pm 0.04$ & $3.53 \pm 0.03$ & $3.53 \pm 0.01$ & $3.42 \pm 0.04$ & $3.39 \pm 0.01$ \\
5 & $4.56 \pm 0.01$ & $3.84 \pm 0.02$ & $3.62 \pm 0.01$ & $3.55 \pm 0.02$ & $3.48 \pm 0.02$ & $3.43 \pm 0.01$ \\
6 & $4.56 \pm 0.01$ & $4.01 \pm 0.02$ & $3.67 \pm 0.06$ & $3.62 \pm 0.04$ & $3.59 \pm 0.03$ & $3.55 \pm 0.04$ \\
7 & $4.56 \pm 0.02$ & $4.03 \pm 0.05$ & $3.77 \pm 0.05$ & $3.65 \pm 0.06$ & $3.61 \pm 0.03$ & $3.56 \pm 0.04$ \\
8 & $4.57 \pm 0.01$ & $4.13 \pm 0.06$ & $3.87 \pm 0.02$ & $3.70 \pm 0.01$ & $3.63 \pm 0.02$ & $3.58 \pm 0.01$ \\
\hline
\end{tabular}

Concentration of $\mathrm{H}^{+}$(in $\mathrm{mol} / \mathrm{dm}^{3}$ ) was calculated from the $\mathrm{pH}$. The increasing acidity of the test liquid for samples containing larger amounts of API led to more spectacular differences than did the change in $\mathrm{pH}$.

Quantity of $\mathrm{H}^{+}$in $4.00 \mathrm{~mL}$ liquid can be calculated from the previous results (Table 16). The basis value of the phosphate buffer $(\mathrm{pH}=4.56)$ was $1.10210^{-7} \mathrm{~mol}$. The $\mathrm{H}^{+}$excess of samples is listed summarized in Table 16.

Table 16. Quantity of $\mathrm{H}^{+}$excess in $4.00 \mathrm{~mL}$ of dissolution medium (mol)

\begin{tabular}{cccccc}
\hline Time (h) & S1 & S2 & S3 & S4 & S5 \\
\hline 0 & 0 & 0 & 0 & 0 & 0 \\
1 & $1.09810^{-6}$ & $1.84910^{-6}$ & $1.77510^{-6}$ & $2.17410^{-6}$ & $2.31810^{-6}$ \\
2 & $9.02210^{-7}$ & $1.25610^{-6}$ & $1.43410^{-6}$ & $1.59610^{-6}$ & $1.80410^{-6}$ \\
3 & $8.42110^{-7}$ & $1.10710^{-6}$ & $1.18410^{-6}$ & $1.43410^{-6}$ & $1.62310^{-6}$ \\
4 & $7.16010^{-7}$ & $1.07010^{-6}$ & $1.08410^{-6}$ & $1.42210^{-6}$ & $1.53210^{-6}$ \\
5 & $4.72410^{-7}$ & $8.49410^{-7}$ & $1.03010^{-6}$ & $1.21410^{-6}$ & $1.38710^{-6}$ \\
6 & $2.77810^{-7}$ & $7.38510^{-7}$ & $8.49410^{-7}$ & $9.18010^{-7}$ & $1.02610^{-6}$ \\
7 & $2.63110^{-7}$ & $5.64010^{-7}$ & $7.78510^{-7}$ & $8.64310^{-7}$ & $9.91510^{-7}$ \\
8 & $1.86410^{-7}$ & $4.25310^{-7}$ & $6.81910^{-7}$ & $8.27510^{-7}$ & $9.50010^{-7}$ \\
\hline
\end{tabular}

The cumulative amount of $\mathrm{H}^{+}$was calculated and hence the dissolution curve could be plotted (Figure 17). It can be seen that there was a break in the curves at about $4 \mathrm{~h}$ for each of the samples. This can be explained by the change in the shape of tablet (see below). Linear (zero-order) approach was used to describe the kinetics of both sections ( $0-4 \mathrm{~h}$ and 5-8 h). 


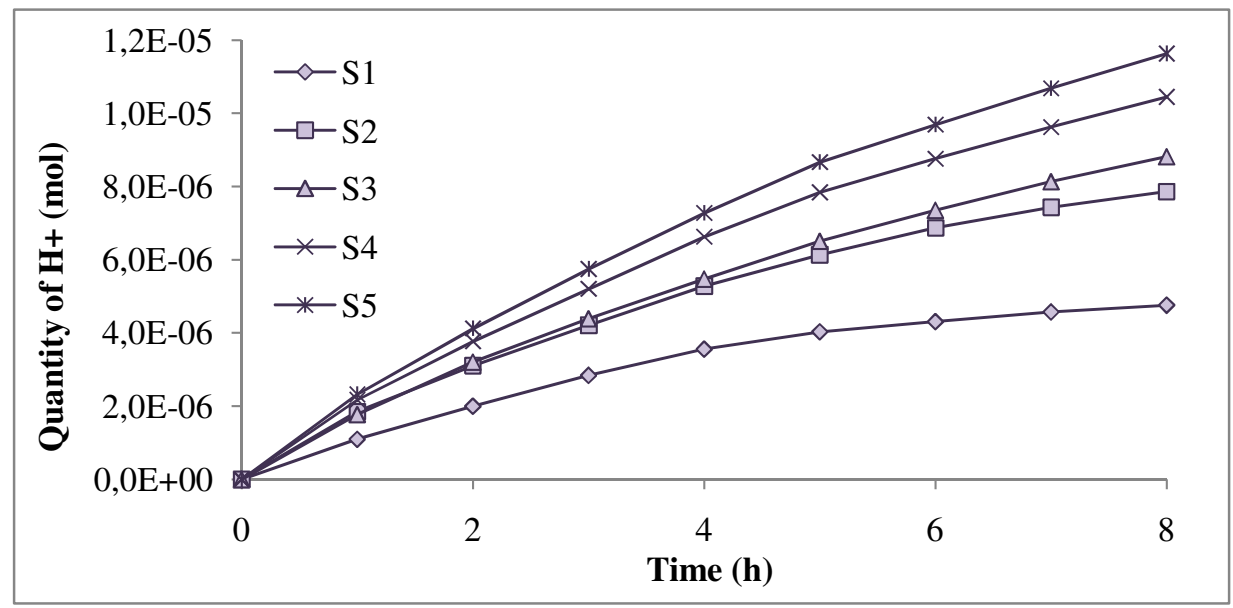

Figure 17. Cumulative curve of dissolved $\mathrm{H}^{+}$-ion

Fitting of both linear sections was very good (Table 17). It can be seen that the slope of the second section is lower than for the first. The ratio of these slopes was the lowest for S1 (28\%). It was higher for S2 (44\%) and S3 (57\%), but subsequently did not rise further (53\% for S4 and 55\% for S5).

Table 17. Slopes of linear sections of dissolution curves

\begin{tabular}{ccccc}
\hline Sample & \multicolumn{2}{c}{ Section 1 } & \multicolumn{2}{c}{ Section 2 } \\
\hline & Slope & $\mathbf{R}^{\mathbf{2}}$ & Slope & $\mathbf{R}^{\mathbf{2}}$ \\
S1 & 0.866 & 0.9969 & 0.245 & 0.9962 \\
S2 & 1.293 & 0.9928 & 0.575 & 0.9926 \\
S3 & 1.357 & 0.9947 & 0.771 & 0.9988 \\
S4 & 1.628 & 0.9967 & 0.869 & 0.9997 \\
S5 & 1.798 & 0.9963 & 0.989 & 0.9998 \\
\hline
\end{tabular}

\subsubsection{Discussion}

It can be established that all of the formulated matrix systems have a $\mathrm{pH}$-decreasing effect throughout $8 \mathrm{~h}$. It does not mean an immediate release of API and thus a sudden decrease in the vaginal $\mathrm{pH}$, which may cause uncomfortable effect.

It is well known that the dissolution of an API from a hydrophilic matrix is controlled by erosion and diffusion. In this case, the liberation of API is also controlled by the detachment from the carrier MCC. Visual checking of the dissolution process revealed that erosion of the tablet could be detected.

Erosion was not a disintegration process into granules, but a detachment of small particles, so that the liberation of LA from the carrier could occur and the dissolved acidic 
component appeared in the medium. This process was quicker than diffusion of the liberated LA through the swollen polymer gel layer. Accordingly, the rate-limiting process of dissolution in the starting period (0-4 h) was mainly erosion of the system and the quicker liberation of API from the carrier. In the second stage (5-8 h), after sphere formation (see below), erosion of this surface was slower (further change in shape did not take place) and the rapidly released portion of LA dissolved in the first stage. Concentration of dissolved $\mathrm{H}^{+}$was therefore lower in this period. This was indicated by the lower $\mathrm{pH}$-decreasing effect in this period. Thus, the importance of the slower phenomena (diffusion and the slower detachment of LA) was higher in this case.

The relative importance of erosion and the weaker interaction between API and the carrier for S1 were demonstrated by the 4-fold faster dissolution in the first stage of the dissolution curve. Since there was no appreciable difference in the erosion behavior of the different tablets, the relevance of the first section for this sample could be that LA was mainly enriched on the surface of the carrier and the detachment was easier. The structure of the MCC particle is loose (as it can be seen in Figure 18) and the liquid can therefore penetrate into the interior, which can be closed during compression. Liberation of this API is more difficult. When the concentration of LA reached a given level (about 9\%), saturation of the surface was detected. The readily removable sites were filled with LA, while the other parts of the liquid formed a new rate-limiting phenomenon. This explains the slower liberation in samples prepared with higher amount of API.

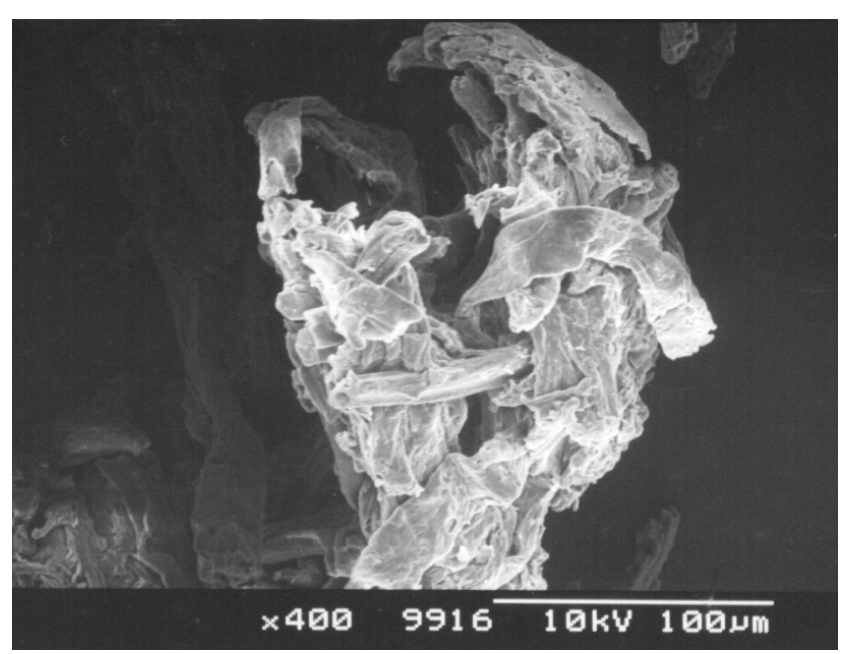

Figure 18. Microcrystalline cellulose (SEM)

Several methods can be used to describe the importance of diffusion and erosion during dissolution tests. In this case, not only these processes must be considered, but also the 
liberation of API from the carrier. The other problem with the evaluation of the effects of these factors was the constant deterioration of the shape. For instance, the Hopfenberg dissolution kinetic model emphasizes the importance of dosage form's shape, but in this case this property cannot be exactly determined during the constant change (from cylindrical to spherical).

\subsection{Summary}

On the basis of this study the following can be concluded:

- There is a correlation between the wetting properties of powder mixtures and the erosion of inert comprimates.

- Factors which increase wetting time are relevant for temperature elevation during the formulation of this system. The effect of operational factors can be predicted from the results of such preformulation studies.

- The composition applied was appropriate for the incorporation of LA. It can be processed into the granulating fluid (up to concentration of 15\%). The presence of LA in the granulating fluid altered significantly neither the particle size distribution, nor the mechanical properties of the granules. The shape of the tablets constantly changed during the dissolution, the main alteration could be seen after $4 \mathrm{~h}$. Erosion and change in shape were very similar for each of the samples.

- The pH-decreasing effect of the tablets was influenced by the concentration of LA applied in the granulating fluid. Erosion is the main parameter responsible for the liberation of LA from this system in the first part of dissolution. This phenomenon increased the possibility of detachment of LA from the insoluble carrier. When the concentration of LA reached a given level, the more readily liberating sites were saturated. In the second stage of dissolution the relevance of erosion was lower and the slower process became more important.

Finally, it can be stated that a controlled release intravaginal matrix tablet can be formulated from the matrix former HPMC and the carrier MCC to ensure a long-acting preparation containing LA. In addition, there was no sign of matrix destruction caused by the LA as a strong acid. 


\section{SECTION II}

\subsection{Aims}

In this part of the work, compatibility of the materials was investigated from a technological point of view through the effect of them on the properties of the dosage form. The aim was the evaluation of the phenomena influencing the functioning and properties of the matrix system and the release of the API in case of a nonionic polymer reacting with an inorganic salt.

\subsection{Materials}

Zinc acetate dihydrate $\left(\mathrm{Zn}(\mathrm{Ac})_{2}\right)$ (Merck $\mathrm{KGaA}$, Darmstadt, Germany) was used as model API. It is a white crystalline powder of leaflets, freely soluble in water [2]. It has a wide range of medical and dietary applications such as a dietary supplement, as an adstringent [115] or in lozenges used to treat the common cold [116]. Zinc salts, e.g. the sulfate, gluconate or acetate, can also be used to treat zinc deficiencies. As an oral daily supplement, this metal ion is used for the treatment of Wilson's disease [117, 118]. The actual salt used in the treatment does not make a difference with respect to efficacy but may affect tolerability, acetate may cause the least gastrointestinal distress [117].

The primary site of absorption of exogenous zinc in the human is in the proximal small bowel $[119,120]$. Zinc has shown clinical efficacy at doses of $50 \mathrm{mg}$ three times daily in the reduction of copper absorption and remove of stored copper [121] and the stimulation of metallothionein synthesis [122-124]. The elimination half-life of zinc in healthy subjects is in the range 0.9-1.2 hours [125], which necessitates several applications a day. Patients' compliance and tolerance could be increased with long-acting sustained and controlled release preparations as the daily intake could be decreased and they make a constant blood level of the APIs possible.

Forms of hydroxypropyl methylcellulose (HPMC) (Metolose 90 SH 100 SR, 4000 SR, 100.000 SR, Shin-Etsu Chemical Co., Ltd., Tokyo, Japan) with different viscosities were used as matrix forming agents. The notations for the different (low, medium and high) viscosities of the Metolose used in this work were as follows: $100 \mathrm{SR}-\boldsymbol{L} \boldsymbol{V}, 4000 \mathrm{SR}-\boldsymbol{M V}$ and 100.000 SR $-\boldsymbol{H} \boldsymbol{V}$. High viscosity grades may be used to retard the release of the water soluble drugs 
from the matrix [126]. This component is frequently utilized to form floating matrix systems $[127,128]$.

Sodium bicarbonate $\left(\mathrm{NaHCO}_{3}\right.$, Solvay S.A., Brussels, Belgium) was applied as gas-forming agent. It is generally used in pharmaceutical formulations as a source of carbon dioxide in effervescent tablets and granules. Recently, $\mathrm{NaHCO}_{3}$ has been used as a gas-forming agent in alkaline raft systems [129, 130], and in floating, controlled release oral dosage forms $[131,132]$. It is a white, crystalline powder with a saline, slightly alkaline taste. $\mathrm{NaHCO}_{3}$ reacts with acids, acidic salts, and many alkaloid salts, with the evolution of carbon dioxide [133].

Lactose monohydrate (Ph. Eur., Hungaropharma Plc, Budapest, Hungary) was used as a substituent of the API at a certain part of the study. It is white to off-white crystalline particle or powder. It is freely but slowly soluble in water [2].

\subsection{Preparation of powder mixtures}

As a preliminary step, the $\mathrm{Zn}(\mathrm{Ac})_{2}$ and $\mathrm{NaHCO}_{3}$ were size-reduced in a mortar (Retsch RM 100, Retsch GmbH, Haan, Germany) for $10 \mathrm{~min}$. Particle sizes were determined with the analytical sieve mentioned above (see Section I. 4.3.2.1) and particles with diameters of 100-200 $\mu \mathrm{m}$ were used in the study. The drug and the excipients were mixed in the above mentioned rotating shaker mixer (see Section I. 4.4.1.2.1) at $50 \mathrm{rpm}$ for $10 \mathrm{~min}$. The amount of API was calculated on the basis of the zinc requirement [117], which is equivalent to $500 \mathrm{mg}$ of $\mathrm{Zn}(\mathrm{Ac})_{2}$ a day. Compositions were given for tablets with $1.0 \mathrm{~g}$ in mass (Table 18).

Table 18. Compositions

\begin{tabular}{ccccc}
\hline Materials & \multicolumn{5}{c}{ Amount of components (mg) } \\
\hline $\mathrm{Zn}(\mathrm{Ac})_{2}$ & 500 & 500 & 500 & 500 \\
$\mathrm{NaHCO}_{3}$ & 100 & 150 & 200 & 250 \\
$\mathrm{HPMC}$ & 400 & 350 & 300 & 250 \\
\hline
\end{tabular}

\subsection{Preparation of matrix tablets}

Tablets were prepared with the above mentioned hydraulic press (see Section I. 4.4.1.2.2); round and flat punches $13 \mathrm{~mm}$ in diameter were used. $1 \mathrm{~g}$ of powder mixture was compressed at $3 \times 10^{8} \mathrm{~Pa}$. Additional excipients (lubricant and glidant) were not applied. In the second part of the work, powder mixtures containing lactose monohydrate as the substituent of $\mathrm{Zn}(\mathrm{Ac})_{2}$ were prepared; the ratio of the components was not changed. 


\subsection{Methods of investigation and results}

\subsubsection{Evaluation of water uptake}

For an understanding of the effects of the individual components on the water uptake of the system, the components and the binary and ternary powder mixtures were tested. To achieve controlled release through the use of a water soluble polymer such as HPMC, the polymer must quickly hydrate on the outer tablet skin to form a gelatinous layer. A rapid formation of a gelatinous layer is critical to prevent wetting of the interior and disintegration of the tablet core. Once the original protective gel layer is formed, it controls the penetration of additional water into the tablet [8].

The method detailed in Section I (see 4.3.1.2.1) was applied. $0.1 \mathrm{~g}$ of the different forms of HPMC, $0.25 \mathrm{~g}$ of each powder mixture and $0.5 \mathrm{~g}$ each of $\mathrm{Zn}(\mathrm{Ac})_{2}$ and $\mathrm{NaHCO}_{3}$ were tested; 5 parallel experiments were performed in every case. The investigation was carried out for $15 \mathrm{~min}$.

First, the Enslin numbers of $\mathrm{Zn}(\mathrm{Ac})_{2}$ and the excipients were determined (Figure 19). The water uptakes of the different forms of HPMC were prolonged: for the LV and MV samples, there was no significant difference between the values (LV: $2.838 \pm 0.055 \mathrm{~mL} / \mathrm{g}$ and $\mathrm{MV}$ : $2.819 \pm 0.185 \mathrm{~mL} / \mathrm{g}$ ), whereas the quantity of water was higher for the $\mathrm{HV}$ sample $(3.629 \pm 0.161 \mathrm{~mL} / \mathrm{g})$. Their wetting was not finished by the end of the test. This was caused by the restriction of the gel layer of the swelling polymer. The process was very short in the case of $\mathrm{NaHCO}_{3}$, the water uptake occurred in the first $10 \mathrm{~s}$, after which the value was constant $(0.553 \pm 0.023 \mathrm{~mL} / \mathrm{g})$. The API took up the maximum quantity of water in the first $6 \mathrm{~min}$, after which the value was constant $(0.493 \pm 0.031 \mathrm{~mL} / \mathrm{g})$. 


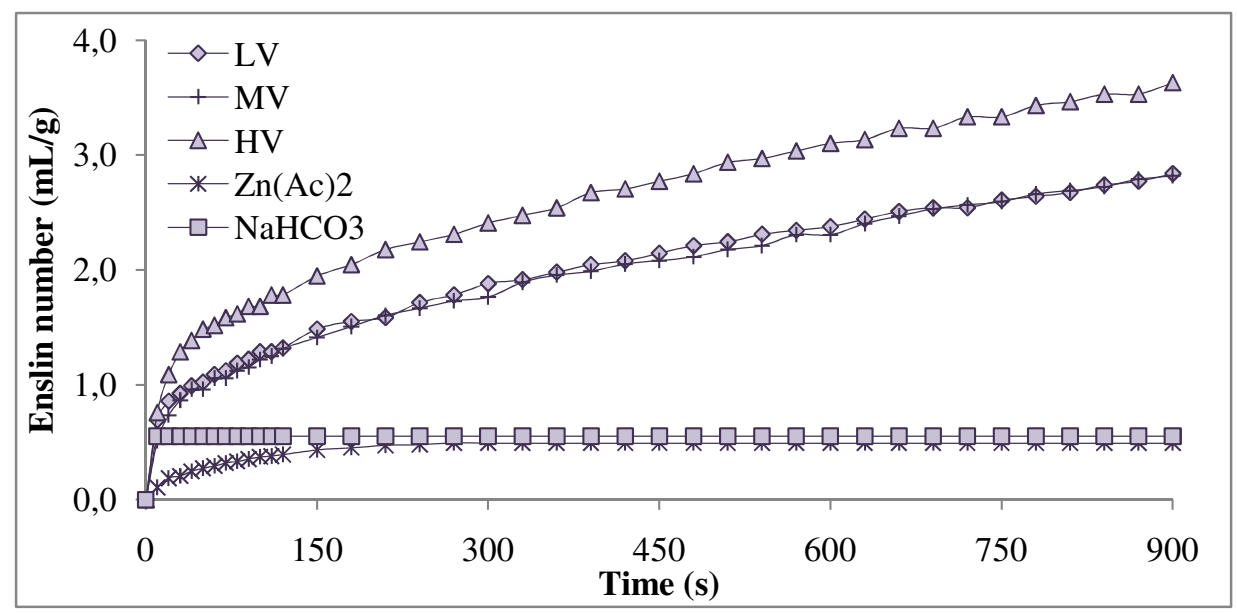

Figure 19. Enslin numbers of active agent and excipients

Next, the water uptakes of the different binary and ternary powder mixtures were determined. The theoretical Enslin numbers were calculated from the Enslin numbers of each component in the ratio of their presence in the powder mixtures. Relative deviations from the calculated values were also determined.

First, the water uptakes of the ternary powder mixtures were determined (Table 19). The quantity of water taken up increased with increasing amount of $\mathrm{NaHCO}_{3}$ in all cases. This change was unexpected as the HPMC content decreased with increasing amount of $\mathrm{NaHCO}_{3}$. It would appear obvious that $\mathrm{NaHCO}_{3}$ formed bubbles, which weakened the gel layer formed and the powder mixtures, so that they could hydrate more quickly. Hydration on the surface was definitely quick, it could be detected visually, but penetration of water through this gel layer was delayed.

Table 19. Enslin numbers of ternary powder mixtures $(\mathrm{mL} / \mathrm{g})($ means $\pm S D)$

\begin{tabular}{cccc}
\hline $\begin{array}{c}\text { Zn(Ac) })_{2}-\mathbf{N a H C O}_{3^{-}} \\
\text {HPMC (\%) }\end{array}$ & LV & MV & HV \\
\hline $50: 10: 40$ & $1.383 \pm 0.061$ & $1.237 \pm 0.039$ & $1.571 \pm 0.023$ \\
$50: 15: 35$ & $1.462 \pm 0.101$ & $1.474 \pm 0.119$ & $1.756 \pm 0.078$ \\
$50: 20: 30$ & $1.927 \pm 0.059$ & $1.781 \pm 0.085$ & $1.996 \pm 0.185$ \\
$50: 25: 25$ & $2.361 \pm 0.089$ & $1.929 \pm 0.104$ & $2.379 \pm 0.023$ \\
\hline
\end{tabular}

Deviations from the calculated Enslin numbers were determined. Powder mixtures with $10 \% \mathrm{NaHCO}_{3}$ could not take up the calculated amount of water, and thus this ratio of $\mathrm{NaHCO}_{3}$ was not sufficient to modify the structures of the powders (Table 20). In contrast, all of the other powders took up much more water than expected (almost double the calculated 
value). This indicates that some interaction happened when the powder mixture came into contact with water.

Table 20. Deviations from calculated Enslin numbers of ternary powder mixtures (\%)

\begin{tabular}{cccc}
\hline $\begin{array}{c}\text { Zn(Ac) })_{2}-N_{\text {NaHCO }}- \\
\text { HPMC (\%) }\end{array}$ & LV & MV & HV \\
\hline $50: 10: 40$ & 96.22 & 86.54 & 89.60 \\
$50: 15: 35$ & 110.55 & 111.98 & 109.75 \\
$50: 20: 30$ & 159.44 & 147.37 & 138.04 \\
$50: 25: 25$ & 215.76 & 176.26 & 184.17 \\
\hline
\end{tabular}

For the evaluation of this situation, the binary mixtures were tested. When there was no $\mathrm{NaHCO}_{3}$ in the powder mixtures (Table 21), a lower quantity of water was taken up, confirming that $\mathrm{NaHCO}_{3}$ is required to change the structures of the powder mixtures and the gel layer of the polymer, enhancing the water uptake. $\mathrm{Zn}(\mathrm{Ac})_{2}$ itself slowed down the water uptake and reduced the amount of water taken up.

Table 21. Enslin numbers of binary powder mixtures without sodium bicarbonate $(\mathrm{mL} / \mathrm{g})$ (means $\pm S D)$

\begin{tabular}{cccc}
\hline $\begin{array}{c}\text { Zn(Ac) })_{2}-N_{(\% C O}{ }_{3}- \\
\text { HPMC (\%) }\end{array}$ & LV & MV & HV \\
\hline $50: 0: 40$ & $1.090 \pm 0.045$ & $1.104 \pm 0.048$ & $1.182 \pm 0.047$ \\
$50: 0: 35$ & $1.077 \pm 0.071$ & $1.103 \pm 0.084$ & $1.196 \pm 0.040$ \\
$50: 0: 30$ & $0.985 \pm 0.024$ & $1.102 \pm 0.083$ & $1.264 \pm 0.026$ \\
$50: 0: 25$ & $0.957 \pm 0.001$ & $1.102 \pm 0.062$ & $1.316 \pm 0.118$ \\
\hline
\end{tabular}

For the binary powder mixtures containing only the additives, lower amounts of water were taken up as compared with the calculated values, clearly demonstrating that the API was also indispensable for the unpredicted wetting (Table 22). This phenomenon points to an interaction between $\mathrm{NaHCO}_{3}$ and $\mathrm{Zn}(\mathrm{Ac})_{2}$, which enhances the water-uptake property of the powders.

Table 22. Deviations from calculated Enslin numbers of binary powder mixtures without sodium bicarbonate (\%)

\begin{tabular}{cccc}
\hline $\begin{array}{c}\mathrm{Zn}(\mathbf{A c})_{2}-\mathbf{N a H C O}_{\mathbf{3}^{-}} \\
\text {HPMC (\%) }\end{array}$ & LV & MV & HV \\
\hline $50: 0: 40$ & 71.01 & 72.31 & 62.66 \\
$50: 0: 35$ & 73.87 & 76.02 & 66.70 \\
$50: 0: 30$ & 71.75 & 80.71 & 75.71 \\
$50: 0: 25$ & 75.07 & 86.84 & 85.56 \\
\hline
\end{tabular}


The properties of powder mixtures without HPMC were also studied. The Enslin numbers of the $50: 10,50: 15,50: 20$ and $50: 25$ mixtures of $\mathrm{Zn}(\mathrm{Ac})_{2}: \mathrm{NaHCO}_{3}$ were as follows: $0.666 \pm 0.023$ (132.32\% deviation), $0.859 \pm 0.020$ (169.45\% deviation), $1.079 \pm 0.073$ (211.43\% deviation) and $1.099 \pm 0.021$ (214.18\% deviation), respectively. These two components together - $\mathrm{Zn}(\mathrm{Ac})_{2}$ and $\mathrm{NaHCO}_{3}$ - were able to take up more water than expected, confirming the occurrence of an interaction. At 20 and $25 \% \mathrm{NaHCO}_{3}$ contents, the amounts of water taken up were more than double. It may be assumed that factors other than the loosing effect of the bubbles formed contribute to the properties of the systems as in case of these powder mixtures there was no matrix-former in the compositions, thus there was not gellified layer which could be loosened by $\mathrm{NaHCO}_{3}$. This interaction was also observed for the ternary powder mixtures, where higher amounts of water were taken up.

$\mathrm{NaHCO}_{3}$ influenced not only the extent of the water uptake of the powder mixtures, but also the kinetics of this process (Figure 20). In the first $3 \mathrm{~min}$, a step could be seen in all of the curves; this was most marked for the powder mixtures with LV. It may refer either to the quick hydration of the polymer or the phenomenon caused by the interaction, after the step, the speed of water uptake was relevantly slower.

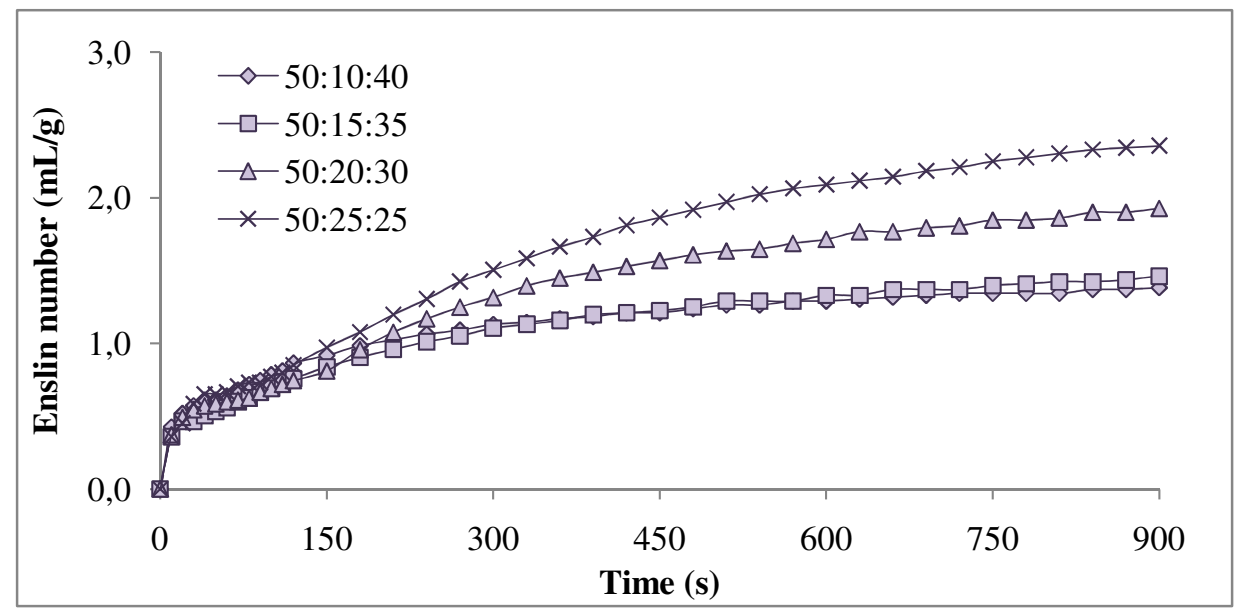

Figure 20. Enslin numbers of ternary powder mixtures with LV 


\subsubsection{Study of matrix disintegration}

Upon complete polymer hydration at the outer surface, chain disentanglement begins to occur, i.e. erosion of the matrix. The rate of erosion is related to molecular weight over a wide range by an inverse power law. In addition, erosion rate is affected by the composition and ionic strength of electrolytes in the liquid medium and by the composition and level of drugs and other additives within the matrix [8].

The disintegration of tablets was evaluated with the disintegration tester mentioned above in 4.3.1.2.2. Tablets were stored in a desiccator for $24 \mathrm{~h}$ before the test. The test liquid was gastric fluid ( $\mathrm{pH}=1.2, \mathrm{Ph}$. Eur.) and the temperature was $37^{\circ} \mathrm{C}$. Twelve parallel experiments were performed. Each test was carried out for a maximum of $8 \mathrm{~h}$, as floating systems with a residence time in the stomach longer than $8 \mathrm{~h}$ are not reasonable [134].

These tests were performed in consecutive steps. First, tablets prepared from the ternary powder mixtures were evaluated (Table 23). The tablets prepared from HPMC with different viscosities differed appreciably in behavior. For LV, the time needed for disintegration of the tablets with the highest HPMC content was approximately $10 \mathrm{~min}$, which was slightly more than for the other compositions. Thus, there was no prolonging effect in these tablets: only a few minutes was necessary for the complete disintegration of the systems.

At higher viscosities, unexpected behavior of the tablets was experienced. At $10 \% \mathrm{NaHCO}_{3}$ content, a higher initial value was observed for both MV and HV HPMC, and thus the effect of the effervescent component in these mixtures was not significant. At higher $\mathrm{NaHCO}_{3}$ content, there was a continuous increase in the duration of disintegration. For these tablets, the disintegration time did not decrease with increasing amount of $\mathrm{NaHCO}_{3}$ as expected, but continuously increased, so that there was a prolonged effect. The presumed interaction appeared to be proven, as the composition and consequently the properties of the powder mixtures changed on contact with water. The interaction affected not only the wateruptake properties of the powder mixtures, but also the duration of disintegration.

Table 23. Disintegration times of tablets prepared from ternary powder mixtures (min) (means $\pm S D)$

\begin{tabular}{cccc}
\hline $\begin{array}{c}\text { Zn(Ac) })_{2}-\mathrm{NaHCO}_{\mathbf{3}^{-}} \\
\text {HPMC (\%) }\end{array}$ & $\mathbf{L V}$ & MV & HV \\
\hline $50: 10: 40$ & $10.5 \pm 0.8$ & $31.5 \pm 13.9$ & $>480.0$ \\
$50: 15: 35$ & $10.4 \pm 1.2$ & $15.2 \pm 4.3$ & $153.3 \pm 37.0$ \\
$50: 20: 30$ & $10.2 \pm 2.0$ & $21.6 \pm 6.0$ & $231.2 \pm 74.1$ \\
$50: 25: 25$ & $7.3 \pm 1.0$ & $80.2 \pm 10.2$ & $336.8 \pm 58.6$ \\
\hline
\end{tabular}


To confirm this, other tests were performed. The duration of disintegration of the polymers, the binary powder mixtures containing $\mathrm{Zn}(\mathrm{Ac})_{2}$ and the different forms of HPMC, and the binary powder mixtures containing $\mathrm{NaHCO}_{3}$ and the different forms of HPMC were also measured, and any of them disintegrated during $8 \mathrm{~h}$. Hence, it can be stated that the presence of $\mathrm{NaHCO}_{3}$ and the API is necessary for the detected disintegration time.

In the following step, the API, which is a necessary component of the interaction, was substituted with lactose monohydrate. The solubility of this component is similar to that of $\mathrm{Zn}(\mathrm{Ac})_{2}$ in water and there is no known interaction between this material and the other components. The disintegration time of the tablets was then measured again (Table 24). A decrease in the erosion time of the tablets was detected with increasing content of $\mathrm{NaHCO}_{3}$. This tendency was detected for every HPMC sample. In accordance with the expectations, the binding effect of the smaller amount of polymer was insufficient to counteract the disintegration effect of the gas-forming component. These tests emphasized the importance of the interaction between the active and effervescent agent on the erosion of the dosage form.

Table 24. Disintegration times of tablets prepared from powder mixtures containing lactose monohydrate (min) (means $\pm S D)$

\begin{tabular}{cccc}
\hline $\begin{array}{c}\text { Lactose-NaHCO } \\
\text { HPMC }\end{array}$ & LV & MV & HV \\
\hline $50: 10: 40$ & $46.1 \pm 9.1$ & $>480.0$ & $>480.0$ \\
$50: 15: 35$ & $23.8 \pm 1.6$ & $109.9 \pm 13.5$ & $>480.0$ \\
$50: 20: 30$ & $19.0 \pm 1.1$ & $62.8 \pm 10.4$ & $70.2 \pm 16.6$ \\
$50: 25: 25$ & $14.3 \pm 0.8$ & $13.7 \pm 1.2$ & $20.4 \pm 1.9$ \\
\hline
\end{tabular}

A number of recent studies have shown this for even the simplest case, the interaction of HPMC and water. The effects of interactions can be accentuated by the conditions that exist within a hydrophilic matrix tablet, from the fully hydrated outer surface through various states of partial hydration to the dry inner core. In these partially hydrated regions, the "concentration" of the drug, other excipients, water, and species from the medium may be relatively high, creating a condition favorable to interaction with HPMC. The hydration and gelation of HPMC under these conditions are only now beginning to be understood. One approach is to consider these interactions as resulting from specific binding of smaller molecules to HPMC, from so-called "generic effects" resulting from disruption of solvent (water) structure and solvent dilution, or from a combination of the two [8].

Interactions between drugs and HPMC that negatively impact polymer hydration are relatively rare. The combination of $\mathrm{Zn}(\mathrm{Ac})_{2}$ and $\mathrm{NaHCO}_{3}$ is supposed to act enhancing 
hydration and swelling of HPMC, thereby accelerating gel layer formation. This blocks solvent to percolate to the interior of the tablet, leading to delayed disintegration.

\subsubsection{Buoyancy}

The buoyancy of the tablets was studied at $37 \pm 0.5{ }^{\circ} \mathrm{C}$, in $150 \mathrm{~mL}$ of gastric fluid at pH 1.2 (Ph. Eur.). The floating lag times - the duration of the period between the placing of the tablet in the medium and the tablet floating - and durations of tablet floating were determined by visual observation. Tablets were stored in a desiccator for $24 \mathrm{~h}$ before the test. Three repetitions were done.

The gastric floating system involved $\mathrm{NaHCO}_{3}$ as a gas-forming agent dispersed in the hydrogel matrix. On reacting with hydrochloric acid, the bicarbonate ion is converted to carbon dioxide in the form of bubbles on the surface of the tablets, which caused the tablets to float in the fluid for more than $4 \mathrm{~h}$ in vitro. On the basis of the disintegration studies, it can be stated that only HV samples might be appropriate for the formulation of a floating drug delivery system. Thus, only these tablets were investigated further in this study; floating lag times and buoyancy (Figure 21) were determined visually. The samples with 10 or $15 \% \mathrm{NaHCO}_{3}$ content floated for only $17 \mathrm{~min}$ and $64 \mathrm{~min}$, respectively, which is not appropriate for the formulation of a floating system, whereas the samples with 20 or $25 \%$ gas-forming agent floated for a minimum of $4 \mathrm{~h}$. Bubbles entrapped in the gellified matrix layer can also be detected visually (Figure 22).

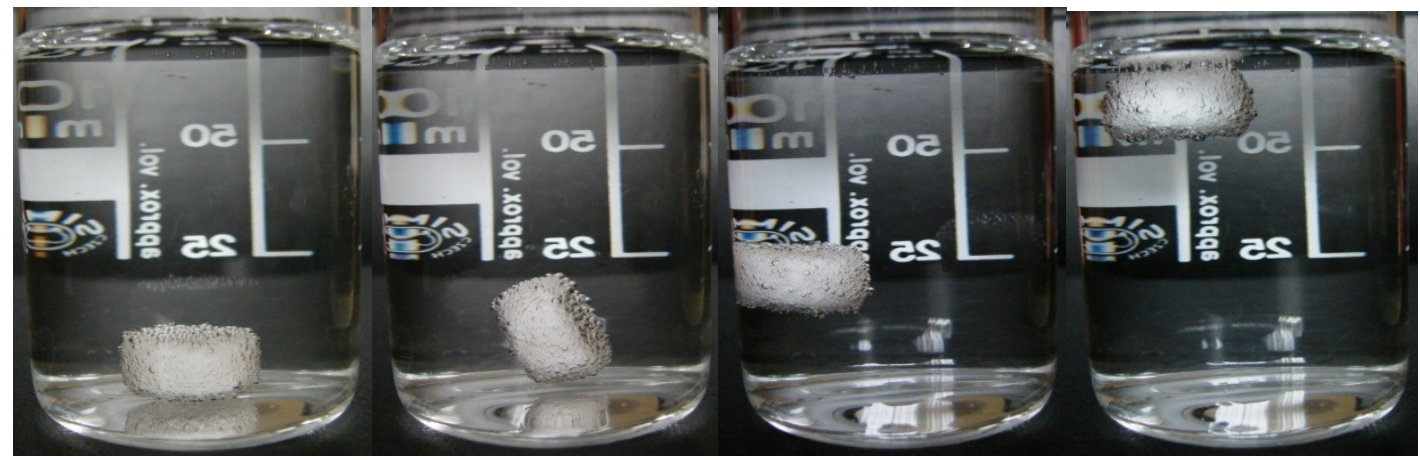

Figure 21. Flotation of matrix tablets $(0-4 \mathrm{~min})$ 


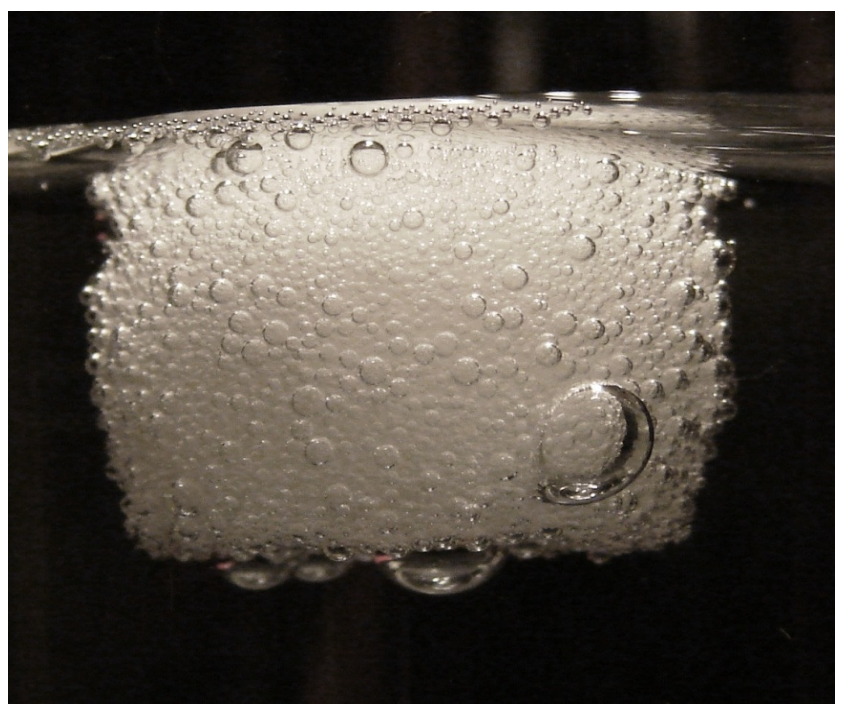

Figure 22. Bubbles entrapped in the gellified matrix after $4 \mathrm{~h}$

\subsubsection{Dissolution study}

The rates of in vitro release of $\mathrm{Zn}(\mathrm{Ac})_{2}$ from the matrix tablets were determined in $900 \mathrm{~mL}$ gastric acid (pH=1.2, Ph. Eur.) by the paddle method (Ph. Eur.). Recent methodology as described in Ph. Eur. states: "For the paddle apparatus, place the preparation at the bottom of the vessel before starting rotation of the blade; dosage forms that would otherwise float are kept horizontal at the bottom of the vessel using a suitable device, such as a wire or glass helix". On the basis of that, dissolution tests were carried out under sink conditions. Tablets were kept at the bottom of the device with a few turns of a wire. Tablets were stored in a desiccator for $24 \mathrm{~h}$ before the test. The paddle rotation speed was kept at $50 \mathrm{rpm}$, and the temperature at $37 \pm 0.5{ }^{\circ} \mathrm{C}$.

Zn contents were measured by X-ray fluoresence analysis (Philips MiniPal PW 4025, Philips Analytical, Almelo, Netherlands). This is a nondestructive physical method used for chemical elemental analysis of materials in the solid or liquid state. The specimen is irradiated by photons or charged particles of sufficient energy to cause its elements to emit (fluoresce) their characteristic X-ray line spectra. The detection system allows the determination of the energies of the emitted lines and their intensities. Elements in the specimen are identified by their spectral line energies or wavelengths for qualitative analysis, and the intensities are related to their concentrations for quantitative analysis. The counting times required for analysis range from a few seconds to several minutes per element, depending upon specimen characteristics and required accuracy; but they may be much longer for trace analysis and thin 
films. The results are in good agreement with wet chemical and other methods of analysis [135].

During the measurements, the conditions applied were $12 \mathrm{kV}$ and $100 \mu \mathrm{A}$, with a kapton filter and an air purge. The samples were measured during $60 \mathrm{~s}$, repeated in triplicate for each sample. The concentrations of $\mathrm{Zn}(\mathrm{ppm})$ were calculated by means of linear calibration $\left(\mathrm{R}^{2}=0.9945\right)$ from the intensities of the $\mathrm{K}_{\alpha}$ lines of the detected radiation. The dissolved drug concentration was calculated on the basis of the zinc content of $\mathrm{Zn}(\mathrm{Ac})_{2}$.

From the results of the preformulation studies of the initial twelve compositions, the $\mathrm{HV}$ mixtures with higher $\mathrm{NaHCO}_{3}$ content (20 and 25\%) proved be appropriate for an extended release preparation. The dissolution characteristics of the sample with $20 \%$ gas-forming agent and 30\% HPMC were studied (Figure 23). It was obvious, that the bulk of the API dissolved in the initial period of time after coming into contact with the gastric acid, while the dissolution of the remaining part was slow and continuous.

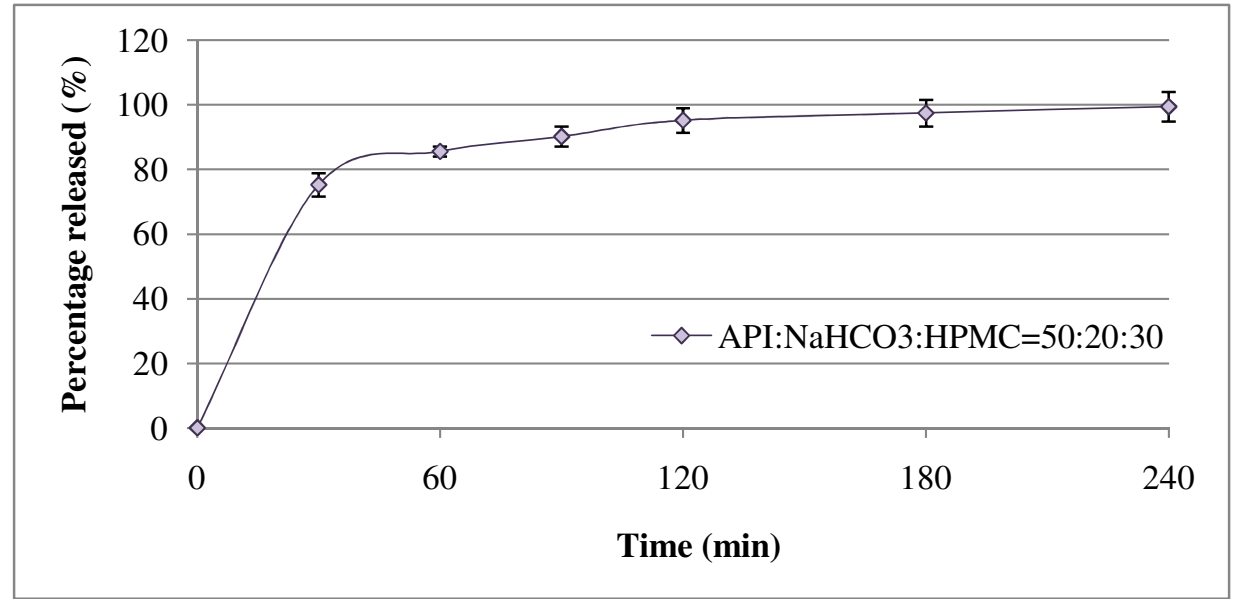

Figure 23. Dissolution of $\mathrm{Zn}(\mathrm{Ac})_{2}$ from tablets containing $20 \% \mathrm{NaHCO}_{3}$ and $30 \% \mathrm{HPMC}$

The initial fast dissolution of the API may be explained by the fact that the hydration, swelling and erosion - or we can say disintegration - of the floating tablet was very intensive in the first minutes of its reaction with gastric acid. Formulation of air bubbles loosened the structure of the developing matrix, the evolving gas permeated through the gel layer leaving gas bubbles or pores which could have increased the rate of release of the API from the matrix. 
After 10-15 min, the outer layer of the tablet reached its optimal hydration state, most of the gas bubbles were entrapped in the gel layer, which could have slowed down the dissolution. Thus in this part, diffusion became the rate-limiting step.

It is important to emphasize that conditions of the dissolution study were relevantly different from the conditions present in the stomach. In the in vitro dissolution studies, the dosage form was not able to float - it was the requirement of the Pharmacopoeia, however in the stomach the dosage form would probably float on the surface of the gastric fluid.

\subsection{Conclusions}

On the basis of this study the following can be concluded:

- On the basis of the preformulation studies, it can be stated that polymers with low viscosity grades did not prove to be appropriate for the formulation of a controlled release preparation in this system.

- Alteration of the ratio of the excipients resulted in an unpredicted significant influence on the properties of the dosage form. The interaction between $\mathrm{Zn}(\mathrm{Ac})_{2}$ and $\mathrm{NaHCO}_{3}$ caused a relevant modification in the water uptake of the powder mixture and in the disintegration of the tablets. Independent tests revealed an interaction between these two components when they came into contact with water, so that prediction of the properties of the dosage form from the parameters of the starting components was impossible.

- The combination of $\mathrm{Zn}(\mathrm{Ac})_{2}$ and $\mathrm{NaHCO}_{3}$ at certain ratios acts to enhance hydration and swelling of HPMC, thereby accelerating gel layer formation. This blocks solvent to percolate to the interior of the tablet, leading to delayed disintegration. Therefore, this phenomenon was applied to develop a prolonged effect.

Finally, it can be stated that appropriate systems with prolonged disintegration times, appropriate buoyancy and controlled release can be formulated from $\mathrm{Zn}(\mathrm{Ac})_{2}$ by using $\mathrm{NaHCO}_{3}$ as gas-forming agent and Metolose $90 \mathrm{SH} 100000 \mathrm{SR}$ as a matrix and gel-forming component. The phenomena experienced during the investigations occurred only in the ternary systems, so prediction of them from the properties of the binary systems was impossible. Therefore, in case of such systems, compatibility studies are recommended to be carried out in complex systems. 


\section{FINAL CONCLUSION, NOVELTY, PRACTICAL USEFULNESS}

To achieve an optimal drug release, solid hydrophilic matrices applied via two different administration routes were studied in details. One of the systems was intended to be applied vaginally, while the other was a special type of oral administration, it was a floating system. The main aims of the study were the formulation and detailed investigation of eroding hydrophilic matrix systems applying HPMC as matrix forming agent. Additionally, investigation of the effect of the aggressive APIs from the technological point of view was the goal of the study as well; therefore, their effect on the drug release from the matrix systems has been studied in details.

Novelty and practical usefulness of the systems formulated:

- As an alternative for vaginal washing solutions controlling the vaginal $\mathrm{pH}$, a solid vaginal hydrophilic drug delivery system containing a fluid API, a mucoadhesive and bioerodible matrix former and a filler familiar with the vaginal flora was successfully formulated, and it has showed controlled release during $8 \mathrm{~h}$.

- Formulation of a gastroretentive drug delivery system as an alternative for patients suffering from Wilson's disease has been prepared. The results may be useful in the development of a sustained release dosage form containing $\mathrm{Zn}(\mathrm{Ac})_{2}$ with a prolonged GRT for the treatment of Wilson's disease.

- The combination of $\mathrm{Zn}\left(\mathrm{A}_{\mathrm{c}) 2}\right.$ and $\mathrm{NaHCO}_{3}$ at certain ratios acts to enhance hydration and swelling of HPMC, thereby accelerating gel layer formation. This blocks solvent to percolate to the interior of the tablet, leading to delayed disintegration. Therefore, this phenomenon was applied to develop a prolonged effect.

In case of both systems, some kind of unexpected phenomena occurred. Through the substantial investigations of the nature of these phenomena, a better understanding of the processes may be achieved. These are good examples of significant changes occurring during the formulation of new sensitive delivery systems. It can be stated that different types of HPMC can be utilized for the formulation of hydrophilic matrix systems with different administration routes but very well structured preformulation studies must be performed. These tests should not be only chemical evaluations, but others considering technological aspects as well. 


\section{REFERENCES}

[1] Swarbrick, J., Boylan, J. C.: Encyclopedia of pharmaceutical technology, $2^{\text {nd }}$ Edition, Volume 1-3, Marcel Dekker Inc., New York, Basel, 2002

[2] European Pharmacopoeia, $4^{\text {th }}$ Edition, Council of Europe, Strasbourg Cedex, France, 2001

[3] Baker, R. W.: Controlled release of biologically active agents, John Wiley \& Sons, New York, 1987

[4] Aulton, M. E. Aulton's Pharmaceutics: The Design and Manufacture of Medicines, Elsevier Health Sciences, New York, pp490-499, 2007

[5] Tiwari, S. B., Rajabi-Siahboomi, A. R.: Extended-Release Oral Drug Delivery Technologies in Drug delivery systems, Jain, K. K., 217-239, Springer Verlag, Berlin, 2008

[6] Abdul, S., Poddar S.S. J. Control. Release, 97:393-405, 2004

[7] Verma, M. V. S., Kaushal A. M., Garg, A., Garg, S. Am. J. Drug Deliv. 2:43-57, 2004

[8] http://www.colorcon.com.cn/literature/marketing/mr/Extended\%20Release/METHOC EL/English/hydroph_matrix_broch.pdf

[9] Velasco, M. Ford, J. L., Rowe, P., R. Rajabi-Siahboomi, A. J. Control. Release $57: 75-85,1999$

[10] Varghas, C. I., Ghaly. E. S. Drug Dev. Ind. Pharm. 25:1045-1050, 1999

[11] Maggi, L., Machiste, E. O., Torre, M. L., Conte, U. Eur. J. Pharm. Biopharm. 48:37-42, 1999.

[12] Alderman, D. A. Int. J. Pharm. Technol. Prod. Manuf. 5:1-9, 1984

[13] Kaparissides, C., Alexandridou, S., Kotti, K., Chaitidou, S. Journal of Nanotchnology. DOI: 10.2240/azojono0111, 2006

[14] Coviello, T., Matricardi, P., Marianecci, C., Alhaique, F. J. Control. Release Vol. 119, Issue 1, 5-24, 2007

[15] Mori, Masao, Release controlled transdermal therapeutic system US Patent 5695779, 1997

[16] Mandal, S., Mandal, S. Int. J. Pharm. Sci. Vol. 3, Issue 1, Article 013, 56-60, 2010

[17] Nayak, A. K., Maji, R., Das, B. As J. Pharm. Clin. Res., 3(1):2-10, 2010

[18] Hussain, A., Ahsan, F. J. Control. Release, 103:301-313, 2005

[19] Woolfson, A.D., Malcolm, R.K., Gallagher, R.J. J. Control. Release 91:465-476, 2003 
[20] Crowder, T.M., Hickey, A.J., Loueym, M.D., Orr, N. A Guide to Pharmaceutical Particulate Science, Interpharm/CRC, Boca Raton, 2003

[21] Rouge, N., Buri, P., Doelker, E., Int. J. Pharm. 136:117-139, 1996

[22] Sato, Y., Kawashima, Y., Takeuchi, H., Yamamoto, H. Int. J. Pharm. 275:97-107, 2004

[23] Cooreman, M. P., Krausgrill, P., Hengels, K. J. Antimicrob. Agents Chemother. $37: 1506-1509,1993$

[24] Yang, L., Eshraghi, J., Fassihi, R. J. Contr. Release 57:215-222, 1999

[25] Umamaheshwari, R. B., Jain, S., Bhadra, D., Jain, N. K. J. Pharm. Pharmacol. 55:1607-1613, 2003

[26] Singh, B. N., Kim, K. H. J. Contr. Release 63:235-259, 2000

[27] Jain, S. K., Awasthi, A. M., Jain, N. K., Agrawal, G. P. J. Contr. Release 107:300-309, 2005

[28] Atyabi, F., Sharma, H. L., Mohammad, H. A. H., Fell, J.T. J. Control. Release 42:105-113, 1996

[29] Iannuccelli, V., Coppi, G., Sansone, R., Ferolla, G. Int. J. Pharm. 174:55-62, 1998

[30] Deshpande, A. A., Rhodes, C. T., Shah, N. H., Malick, A. W. Drug Dev. Ind. Pharm. 22(6):531-539, 1996

[31] Fix, J. A., Cargill, R., Engle, K. Pharm. Res. 10:1087-1089, 1993

[32] Klausner, E. A., Lavy, E., Stepensky, D., Friedman, M., Hoffman, A. Pharm. Res. $19: 1516-1523,2002$

[33] Urquhart, J., Theeuwes, F. US Patent 4, 434, 153, 1984

[34] Mamajek, R. C. US Patent 4, 207, 890, 1980

[35] Vasir, J. K., Tambwekar, K., Garg, S. Int. J. Pharm. 255(1-2):13- 32, 2003

[36] Wang, J., Tabata, Y., Bi, D., Morimoto, K. J. Control Release 73:223-231, 2001

[37] Akiyama Y, Nagahara N: Novel formulation approaches to oral muco-adhesive drug delivery systems. In Bioadhesive Drug Delivery Systems - Fundamentals, Novel Approaches and Development. Edited by Mathiowitz, E., Chickering, III D. E. , Lehr, C. M. New York. Dekker; 477-505, 1999

[38] Cargill, R., Caldwell, L. J., Engle, K., Fix, J. A., Porter, P. A., Gardner, C. R. Pharm. Res. 5:533-536, 1988

[39] Caldwell, L. J., Gardner, C. R., Cargill, R. C. US Patent 4, 735, 804, 1988

[40] Caldwell, L. J., Gardner, C. R., Cargill, R. C., Higuchi, T. US Patent 4, 758, 436, 1988

[41] Caldwell, L. J., Gardner, C. R., Cargill, R. C. US Patent 4, 767, 627, 1988 
[42] Kedzierewicz, F., Thouvenot, P., Lemut, J., Etienne, A., Hoffman, M., Maincent, P. J. Control. Release 58:195-205, 1999

[43] Rednick, A.B. US Patent 3, 507, 952, 1970

[44] Bechgaard, H., Ladefoged, K. J. Pharm. Pharmacol. 30:690-692, 1978

[45] Davis, S. S., Stockwell, A. F., Taylor, M. J., Hardy, J. G., Whalley, D. R., Wilson, C. G. H., Faure, A., York, P., Rowe, R. C., Eur. Pharm. Biopharm., 52:269, 2001

[46] Gröning, R., Heun, G. Drug Dev. Ind. Pharm. 10:527-539, 1984

[47] Gröning, R., Heun, G. Int. J. Pharm. 56:111-116, 1989

[48] Khosla R, Davis SS: Int J Pharm 62:R9-R11., 1990

[49] Timmermans J, Moe“s AJ: J. Pharm. Sci. 83:18-24, 1994

[50] Hasler, W .L. in: Yamada T. (Ed.), Textbook of Gastroenterology II, Vol. 1, Lippincott, J. B., Philadelphia, pp. 181-206, 1995

[51] O’Reilly, S., Wilson, C. G., Hardy, J. G. Int. J. Pharm. 34:213-216, 1987

[52] Khosla, R., Feely, L. C., Davis, S. S. Int. J. Pharm. 53:107-117, 1989

[53] Abrahamsson, B., Alpsten, M., Hugosson, M., Jonsson, U. E., Sundgren, M., Svenheden, A. J: Pharm Res 10:709-714, 1993

[54] Rubinstein, A., Li, V. H. K., Gruber, P., Robinson, J. R. in: Yacobi, A., HalperinWalega, E. (Eds.), Oral Sustained Release Formulations: Design and Evaluation, Pergamon Press, New York, 125-156, 1988

[55] Backon, J., Hoffman, A. J. Clin. Pharmacol. 32:138-139, 1991

[56] Mojaverian, P., Vlasses, P. H., Kellner, P. E., Rocci, M. L. Jr. Pharm Res 5:639-644, 1988

[57] Read, N. W., Sugden, K., CRC Crit. Rev. Ther. Drug Carrier Syst. 4(3):221-263, 1987

[58] Bennett, C. E., Hardy, J. G., Wilson, C. G. Int. J. Pharm. 21:341-347, 1984

[59] Mojaverian, P., Vlasses, P. H., Kellner, P. E., Rocci, M. L. Jr., Pharm. Res. 5 (10):639-644, 1988

[60] Coupe, A. J., Davis, S. S., Evans, D. F., Wilding, I. R. J. Control. Release 20:155-162, 1992

[61] Nimmo, J., Heading, R. C., Tothill, P., Prescott, L. F. Br. Med. J. 1:587-589, 1973

[62] Streubel, A., Siepmann, J., Bodmeier, R. Curr. Opin. Pharmacol. 6:501-8, 2006

[63] Larhed, A. W., Artursson, P., Grasjo, J., Bjork, K. J. Pharm. Sci. 86(6):660-65, 1997

[64] Minami, H., McCallum, R. W. Gastroenterology 86:1592-1610, 1984

[65] Ehrlein, H .J. Am. J. Physiol. 254:G650-G657, 1988

[66] Hilton, A. K., Deasy, P. B. Int. J. Pharm. 86:79-88, 1992 
[67] Seth, P. R., Tossounian, J. Drug Dev. Ind. Pharm. 10:313-39, 1984

[68] Hwang, S. J., Park, H., Park, K. Crit. Rev. Ther. Drug Carrier Syst. 15(3):243-84, 1998

[69] Reddy, L. H., Murthy, R. S. Crit. Rev. Ther. Drug Carrier Syst. 19(6):553-85, 2002

[70] Bardonnet, P. L., Faivre, V., Pugh, W. J., Piffaretti, J. C., Falson, F. J. Control. Release 111:1-18, 2006

[71] Krogel, I., Bodmeier, R. Int. J. Pharm. 187 (2):175- 184, 1999

[72] Yang, L., Eshraghi, J., Fassihi, R. J. Control. Release 57 (3):215-222, 1999

[73] Ozdemir, N., Ordu, S., Ozkan, Y. Drug Dev. Ind. Pharm. 26 (8):857- 866, 2000

[74] Harrigan, R. M. US Patent 405 5178; 1977

[75] Rubinstein, A., Friend, D. R., Specific delivery to the gastrointestinal tract, in: Domb, A. J. (Ed.), Polymeric Site-Specific Pharmacotherapy, Wiley, Chichester, 282-283, 1994

[76] Hussain, A., Ahsan, F. J. Controlled Release, 103:301-313, 2005

[77] Woolfson, A. D., Malcolm, R. K., Gallagher, R. J. J. Control. Release 91:465-476, 2003

[78] Crowder, T. M., Hickey, A. J., Loueym, M. D., Orr, N.: A Guide to Pharmaceutical Particulate Science, Interpharm/CRC, Boca Raton, 2003

[79] Swarbrick, J., Boylan, J. C.: Encyclopedia of pharmaceutical technology, $2^{\text {nd }}$ Edition, Vol. 1-3, Marcel Dekker Inc., New York, Basel, 2002

[80] Hillary, A. M., Llojd, A. W., Swarbrick, J.: Drug delivery and Targeting for Pharmacists on Pharmaceutical Scientists, Taylor\&Francis, London, 2001

[81] Parfitt, K.: Martindale $32^{\text {nd }}$ Edition, Pharmaceutical Press, London, 1999

[82] Voege, H. Pharm. Ind. 35:78, 1973

[83] Patel, G. M., Patel, M. M. Acta Pharm. 59:273-288, 2009

[84] Aulton, M. E.: Pharmaceutics The Science of Dosage Form Design, Churchill Ltd: Livingstone, 334-359, 2002

[85] http://www.drugdeliverytech.com/cgi-bin/articles.cgi?idArticle=243

[86] http://www.pharmacy.utah.edu/pharmaceutics/pdf/Preformulation.pdf

[87] Nürnberg, E., Surmann, P. (Eds.), Hagers Handbuch der Pharmazeutischen Praxis, $5^{\text {th }}$ Ed., Bd. 2 Methoden, Springer Verlag, Berlin, 60, 1991

[88] Langenbucher, F. Pharm. Ind, 38:472, 1976

[89] de Assis, S. A., Ferreira, B. S., Fernandes, P., Guaglianoni, D. G., Cabral, J. M. S., Oliveira, O. M. M. F. Food Chemistry, 86:333-337, 2004 
[90] Todorovic, J., Ecke, H., Lagerkvis, A. Waste Management, 23:621-629, 2003

[91] Forte, M. M. C., Cunha, F. O. V., Santos, J. H. Z., Zacca, J. J. Polymer, 44:1377-1384, 2003

[92] Sertsou, G., Butler J., Scott, A., Hempenstall J., Rades T. Int. J. Pharm., 245:99-108, 2002

[93] Bajdik, J., Baki, G., Szent-Királlyi, Zs., Knop, K., Kleinebudde, P., Pintye-Hódi, K. J. Pharm. Biomed. Anal. 49:694-701, 2008

[94] Pharmacopoea Hungarica Ed. VIII., Medicina, Budapest, 2003

[95] Zelkó, R., Orbán, Á., Süvegh, K. J. Pharmaceut. Biomed. Anal. 40:249-254. 2006

[96] Collected Application, Thermal Analysis, Pharmaceuticals, Mettler Toledo GmbH, Schwerzenbach, 1998

[97] Höhne, G., Hemminger, W., Flammershein, H. I. Differential Scanning Calorimetry, Springer Verlag, Berlin, 1996

[98] Plummer, C. J. G., Kausch, H.-H. Polymer Bulletin 36:355-360, 1996

[99] Xu, H. Kuo, S.-W. Chang, F.-C. Polymer Bulletin 48:469-474, 2002

[100] Bruni, G., Milanese, C., Bellazzi, G., Berbenni, V., Cofrancesco, P., Marini, A., Villa, M. J. Therm. Anal. Calorim. V89(3):761-766, 2008

[101] Gombás, Á. Szabó-Révész, P., Kata, M., Regdon, G. jr., Erős, I. J. Therm. Anal. Calorim. 68:503-510, 2002

[102] MacKenzie, R. C. J. Therm. Anal, 8:197, 1975

[103] MacKeznie, R. C. Thermochemica Acta, 28:1-6, 1979

[104] Hill, J. O. For Better Thermal Analysis, 2nd Edition, International Confederation of Thermal Analysis, 1990

[105] Mosen, K., Backstrom, K., Thalberg, K., Schaefer, T., Axelsson, A., Kristensen, H. G. Eur. J. Pharm. Biopharm. 64:206-211, 2006

[106] Burnett, D. J., Thielmann, F., Booth, J. Int. J. Pharm. 287:123-133, 2004

[107] Berggren, J., Frenning, G., Alderborn, G. Eur. J. Pharm. Sci. 22:191-200, 2004

[108] Bauer, K. H., Lehmann, K., Osterwald, H. P., Rothang, G., Coated Pharmaceutical Dosage Forms, Medpharm GmbH Scientific Publishers, Stuttgart, 1988

[109] Berggren, J., Alderborn, G. Eur. J. Pharm. Sci. 21:209-215, 2004

[110] Green, R. E. Jr., Winter, J. M. Jr., Lipetzky, K. G. Nondestructive Evaluation (NDE) and Material Properties, IV, 21, 1999

[111] Green, K. A., Green, R. E. Jr. Quantitative Nondestructive Evaluation, 13:571, 1994. 
[112] Hermans, P. H., Weidinger, A. J. Appl. Phys. 19:491-506, 1948

[113] Wang, S., Yu, J., Gao, W. Am. J. Biochem. Biotechnol. 1(4):207-211, 2005

[114] Tüske, Zs., Regdon Jr., G., Erős, I., Srcic, S., Pintye-Hódi, K. Powder Technol. $155: 139-144,2005$

[115] Hefti, A. F., Huber, B. J. Clin. Periodontol. 14:515-518, 2005

[116] Little, P. Evid. Based Med. 6:46, 2001

[117] Roberts, E. A., Schilsky, M. L. Hepatology 47(6):2089-2111, 2008

[118] Brewer, G. J., Dick, R. D., Johnson, V. D., Brunberg, J. A., Kluin, K. J., Fink, J. K. J. Lab. Clin. Med. 132:264-78, 1999

[119] Krebs, N. F., Westcott, J. E., Huffer, J. W., Miller, L. V. FASEB J. 12, A345, 345-348, 1998

[120] Lee, H. H., Prasad, A. S., Brewer, G. J., Owyang, C. Am. J. Physiol. 256:G87-G91, 1989

[121] Brewer, G. J., Dick, R. D., Johnson, V. D., Brunberg, J. A., Kluin, K. J., Fink, J. K., J. Lab. Clin. Med. 132:264-278, 1999

[122] Schilsky, M., Blank, R. R., Czaja, M. J., Scheinberg, I. H., Stockert, R. J., Sternlieb, I. J. Clin. Invest. 84:1562-1568, 1989

[123] Hill, G. M., Brewer, G. J., Prasad, A. S., Hydrick, C. R., Hartmann, D. E. Hepatol. 7:522-528, 1987

[124] Cousins, R. J. Physiol. Rev. 65:238-309, 1985

[125] http://www.ema.europa.eu/docs/en_GB/document_library/EPAR__Scientific_Discussion/human/000535/WC500040791.pdf

[126] Wade, A., Weller, P. J.: Handbook of Pharmaceutical Excipients, $2^{\text {nd }}$ Edition, The Pharmaceutical Press, London, 1994

[127] Jiménez-Martínez, I., Quirino-Barreda, T., Villafuerte-Robles, L. Int. J. Pharm. $362: 37-43,2008$

[128] Xiaoqiang, X., Minjie, S., Feng, Z., Yiqiao, H. Int. J. Pharm. 310:139-145, 2006

[129] Johnson, F. A., Criag, D. Q. M., Mercer, A. D., Chauhan, S. Int. J. Pharm. 159(1):35-42, 1997

[130] Johnson, F. A., Craig, D. Q., Mercer, A., Chauhan, S. Int. J Pharm, 170(2):179-185, 1998

[131] Özdemir, N., Ordu, S., Özkan, Y. Drug Dev. Ind. Pharm. 26(8):857-866, 2000

[132] Wei, Z., Yu, Z., Bi, D. Drug Dev. Ind. Pharm. 27(5):469-474, 2001 
[133] Rowe, R. C., Sheskey, P. J., Weller, P. J. Handbook of Pharmaceutical Excipients, $4^{\text {th }}$ Ed., Pharmaceutical Press, Bath, 2003

[134] Kelly, K. A. Motility of the stomach and gastroduodenal junction, in: Johnson, L. R. (Ed.), Physiology of the Gastrointestinal Tract, vol. 1, $1^{\text {st }}$ ed., Raven Press, New York, 393-410, 1981

[135] McGraw-Hill: Concise Encyclopedia of Science \& Technology, $5^{\text {th }}$ Edition McGraw-Hill Companies, Inc., 605, 2007 


\section{ACKNOWLEDGEMENTS}

I give sincere thanks to my advisors Prof. Dr. Klára Pintye-Hódi and Dr. János Bajdik for their encouragement and guidance during my research work in the University of Szeged. I greatly appreciate their continuous help during the preparation of my thesis. I owe my warm gratitude to them for their criticism and numerous discussions during my Ph.D. work.

I would like to thank Prof. Dr. István Erős and Prof. Dr. Piroska Szabó-Révész, the previous and present Head of the Ph.D. programme of Pharmaceutical Technology for providing me with the possibility to work in this department and complete my work under their guidance. I am also grateful to Prof. Dr. Piroska Szabó-Révész, the present Head of the Department of Pharmaceutical Technology for guiding me with her invaluable advice and inspiring me to work in an accurate way.

Furthermore, I would like to thank Prof. Dr. Peter Kleinebudde, Head of the Pharmaceutics and Biopharmaceutics at Heinrich-Heine University in Düsseldorf for providing me with the opportunity to work in his Department.

I express my kindest thanks all my co-authors for their collaboration in this work. Help from all members in the Department of Pharmaceutical Technology, and some other departments will be greatly appreciated.

Finally, I am deeply grateful to my family and friends for their love and full support in attaining my goal. Their contributions have become an inspiration for completing my postgraduate studies. 


\section{APPENDIX}

\section{Publications Related to The thesis}


I 


\title{
The effect of wetting of powder mixture on the preparation of hydrophilic matrix granules with high-shear granulator
}

\author{
János Bajdik, Gabriella Baki, András Kelemen, Klára Pintye-Hódi * \\ Department of Pharmaceutical Technology, University of Szeged, Eötvös u. 6, H-6720 Szeged, Hungary
}

\section{A R T I C L E I N F O}

\section{Article history:}

Received 6 June 2007

Accepted 18 September 2007

\section{Keywords:}

Factorial design

High-shear granulator

HPMC

Hydrophilic matrix

Wetting

\begin{abstract}
A B S T R A C T
The aim of our work was to determine the main factors which can influence the preparation of matrices and to choose the best parameters for the production of inert matrix granules with a high-shear granulator. Matrices were formulated, which contained hydroxypropyl methylcellulose (HPMC) as a matrix-forming agent, together with lactose monohydrate and microcrystalline cellulose as filler. There was a good correlation between the erosion time of the matrix comprimates and the water uptake of the different powder mixtures. The powder mixtures containing at least $40 \%$ of HPMC exhibited very similar properties to those of pure HPMC. Granules were prepared from the powder mixture with $30 \%$ of HPMC. The optimum amount of granulating fluid (water) was determined according to the quantity of the particles with optimum size. A $2^{4}$ full factorial design was used to determine the operational parameters of the granulation for this composition. A significantly lower amount of waste was attained with a long spheronization time and slow dosing. The gel-forming properties of the HPMC, and hence the slower wettablity mean that the most important factors are those that affect the wettability of the powder mixture, and thus the factors which increase the time of wetting are relevant during the formulation of this matrix system. There was a relationship between the wetting of the powder mixture and forming of granules prepared with high-shear granulator.
\end{abstract}

(C) 2007 The Institution of Chemical Engineers. Published by Elsevier B.V. All rights reserved.

\section{Introduction}

The main aim of dosage form design is to achieve a predictable therapeutic effect to a drug included in a formulation which is capable of large-scale manufacture with reproductible product quality. An understanding of how various process variable affect the technology is necessary for the design of a production that can reliably provide the product in high yields and quality.

Many drugs are formulated into several dosage forms of varying strengths, each having selected pharmaceutical characteristics suitable for a specific application (oral, rectal, nasal and intravaginal, etc.). Intravaginal preparations can nowadays be used to treat several topical problems; because of the good absorption and the lack of a first pass effect, this route can be applied to cure systemic diseases, mainly by hormone replacement (Hussain and Ahsan, 2005; Woolfson et al., 2003; Hillary et al., 2001). Intravaginal therapeutic systems must contain various materials to ensure the appropriate release of the active ingredients. These additives are different polymers, mainly with bioadhesive effects, a feature that is very useful for local and also systemic treatment (Baloğlu et al., 2003; Valenta, 2005). The widely used macromolecular bioadhesive components are cellulose derivatives, chitosan, acrylic components and mixtures of these (Kast et al., 2002; Karasulu et al., 2004; Russo et al., 2004). Most of these materials can be used to produce a soluble hydrophilic matrix system (Vueba et al., 2004). In this case the liberation of the poorly water-soluble active pharmaceutical ingredients (API) is mainly determined by the erosion (the dissolution of the matrix former) (Siepmann and Peppas, 2001). Water-soluble APIs can be liberated by erosion of the matrix and also by diffusion through the formed gel. The

\footnotetext{
* Corresponding author. Tel.: +36 62545576; fax: +36 62545571.

E-mail address: klara.hodi@pharm.u-szeged.hu (K. Pintye-Hódi). 0263-8762/\$ - see front matter (C) 2007 The Institution of Chemical Engineers. Published by Elsevier B.V. All rights reserved. doi:10.1016/j.cherd.2007.10.003
} 
matrices can contain other materials (e.g. fillers, pore formers, etc.), but the biocompatibility (irritation-free) is very relevant for the vaginal forms, since the intact mucous membrane and the bacterial flora protect the vagina against the infections (das Neves and Bahia, 2006).

Solid vaginal products often contain lactose as a filler. This is a natural substrate for the vaginal microflora (lactobacillus), which converts lactose into lactic acid (Aulton, 2002; Ritschel and Bauer-Brandl, 2002). It is well known that problems can arise during the preparation (e.g. sticking and capping) of tablets containing a large amount of lactose monohydrate (Mullarney and Hancock, 2006; Takeuchi et al., 2004). It is therefore practical to use different types of binder and additional fillers for these tablets (mainly cellulose and its derivatives).

Solid intravaginal preparations can contain very small amounts of active ingredients (e.g. $\mu$ g quantities of hormones) and it is well known that the processibility of these materials is very difficult (Woolfson et al., 1999; Nygaard et al., 2004). One possible way to solve this problem is the preparation of a solution from these materials with application of this solution as a binder fluid (Parikh, 1995). This technique is commonly used during the formulation of solid dosage forms. In this case, granules with the same dimensions and structures must be produced because of the desired homogeneous concentration and distribution of the active ingredients. The effects of very small amounts of active ingredients are less relevant as concerns in the properties of dosage forms (e.g. wetting properties, dissolution, etc.). The determining factors are the composition of the carriers (type and quantity of additives) and the operational parameters during the preparation. Optimization of these parameters without API is more important for these systems than for others containing large amounts of active.

In the present study, different types of inert matrices were formulated which can be used to prepare intravaginal matrices with a low amount of active ingredient. The active ingredient can be incorporated into the granulating liquid. The applied systems contained lactose monohydrate and microcrystalline cellulose in a constant ratio (1:1) as filler/binder and hydroxypropyl methylcellulose (HPMC) in different concentrations as a matrix-forming agent. The water uptake (quantity and speed) and degree of erosion of the hydrophilic matrices were evaluated and compared. It is well known that the dissolution of an active agent from a hydrophilic matrix is controlled by erosion and diffusion. A high variability in hydration and erosion behaviour is expected depending on the polymer type and grade as well as on the compaction pressure and the matrix porosity. Knowledge of these parameters is therefore very important. After determination of the appropriate composition of the powder mixture, granules were prepared with a high-shear granulator. Different quantities of water were used as granulating liquid. The amount of liquid was chosen according to the size of the particles and the quantity of waste $(<0.5$ and $>2.0 \mathrm{~mm}$ ). After optimization of the quantity of liquid, the optimum parameters applied during the granulation were determined. A $2^{4}$ full factorial design was used in this step. The optimization parameters were the size of the particles and the yield of the preparation.

The aim of our work was to determine the main factors which can influence the preparation of hydrophilic matrices and to choose the best parameters for the production of granules with a high-shear granulator. Despite the importance of determining the critical control points of formulation of these solid forms, the exact mathematical evaluation has been relatively neglected to date. These parameters are not known in the literature, and in general the settings are empirical. This information is very useful for the application of process analytical technology (PAT). Since gaining a deep understanding of the manufacturing process is at the heart of PAT (Davies and Ellis, 2005).

\section{Materials and methods}

\subsection{Materials}

HPMC (Pharmacoat 606, Type 2910, Shin-Etsu Chemical CO., Ltd., Tokyo, Japan) was used as matrix former. This is a component frequently utilized to form intravaginal bioadhesive systems (Chien and Lee, 2002; Rowe et al., 2003). Microcrystalline cellulose (Vivapur 301, Rettenmaier\&Söhne $\mathrm{GmbH}$, Rosenberg, Germany) was applied as a filler/binder, and $\alpha$-lactose monohydrate (Ph. Eur., Hungaropharma Plc., Budapest) as a filler. The ratio of these components was 1:1 in all samples. The compositions of the powder mixtures were as follows (Table 1).

\subsection{Evaluation of water uptake}

The Enslin number is a simple semi-quantitative measure of the water uptake of a powder and is equal to the amount of fluid absorbed by $1 \mathrm{~g}$ of the powder $(\mathrm{ml} / \mathrm{g})$. An Enslin apparatus with a glass filter and a pipette with $0.01 \mathrm{ml}$ accuracy were used for these experiments. A monolayer of particles took up the maximum quantity of water possible through a filter paper under these conditions. $0.5 \mathrm{~g}$ of each powder was tested; five parallel experiments were performed.

The speed of the water uptake can be evaluated via characteristic water uptake time $\left(t_{63.2 \%}\right)$. It is the time which is necessary for the uptake of $63.2 \%$ of the maximum quantity of water. The fitting revealed that these curves can be described by the Weibull model (Weibull, 1951). The fitting software were

Table 1 - Compositions of powder mixtures

\begin{tabular}{lccc} 
Notation & HMPC (\%) & Lactose monohydrate (\%) & Microcrystalline cellulose (\%) \\
\hline Mix0 & 0 & 50 & 50 \\
Mix10 & 10 & 45 & 45 \\
Mix20 & 20 & 40 & 40 \\
Mix30 & 30 & 35 & 35 \\
Mix40 & 40 & 30 & 30 \\
Mix50 & 50 & 25 & 25 \\
Mix100 (HPMC) & 100 & 0 & 0 \\
\hline
\end{tabular}




\section{Table 2 - Weights of comprimates $(n=10)$}

Sign Weight (mg)

Mix0 $359.7 \pm 16.1$ $367.6 \pm 4.3$ $358.0 \pm 8.2$ $357.1 \pm 3.7$ $359.2 \pm 7.4$ $358.1 \pm 4.9$

Mix 20

$\operatorname{Mix} 30$

$\operatorname{Mix} 40$

Mix50

Mix100 (HPMC)

developed in our institute. A non-linear fitting approach with the following equation was applied:

$M=M_{0}\left\{1-\exp \left[-\frac{(t-T)^{\beta}}{a}\right]\right\}$

where $M$ is the amount of water taken up after time $t ; M_{0}$ the maximum amount of water taken up; $\mathrm{T}$ the delay time; $\beta$ the shape parameter; and $a$ is the time parameter.

\subsection{Erosion study of the matrices}

Matrix compacts prepared from powder mixtures with the same dimensions were produced with a Korsch EKO (Emil Korsch Maschinenfabrik, Germany) instrumented eccentric tablet machine for this. Flat punches $10 \mathrm{~mm}$ in diameter were used. Additional excipients (lubricants and glidants) were not applied.

The constant parameters of the tablets were as followsthickness: $4.00 \pm 0.05 \mathrm{~mm}$, diameter: $10.00 \pm 0.05 \mathrm{~mm}$, upper pressure force: $5 \pm 1 \mathrm{kN}(63.7 \mathrm{MPa})$, the speed of compression: 36 tablets/min, circumstances: $26 \pm 2{ }^{\circ} \mathrm{C}$ and $55 \pm 5 \% \mathrm{RH}$. Naturally, the tablets differed in weight (Table 2).

The erosion of these tablets (the term dissolution is not correct for these systems because of the insoluble microcrystalline cellulose) was evaluated with a disintegration tester (Erweka ZT 71, Erweka GmbH, Heusenstamm, Germany). The liquid was water and the temperature was $37^{\circ} \mathrm{C}$. This test was performed to optimize the composition. Six parallel experiments were performed.

\subsection{Preparation of matrix granules}

The granules were prepared in a high-shear granulator (ProCepT 4M8 granulator, ProCepT nv, Zelzate, Belgium). The critical process data are mixer torque, product temperature, mixer and chopper speed, liquid dosing speed and volume. The granulating liquid was water. The parameters during the determination of the optimum quantity of water were the same, except for the quantity of water.

- Speed of the impeller: $750 \mathrm{rpm}$.

- Speed of the chopper: $2500 \mathrm{rpm}$.

- Dosing speed of the liquid: $10 \mathrm{ml} / \mathrm{min}$

- Spheronization time: 1 min.

- Weight of the powder mixture: $150 \mathrm{~g}$.

The quantities of the liquid to $100 \mathrm{~g}$ of powder mixture were $20 \mathrm{~g}$ (S1), $25 \mathrm{~g}$ (S2), $27.5 \mathrm{~g}$ (S3), $30 \mathrm{~g}$ (S4), $35 \mathrm{~g}$ (S5) or $40 \mathrm{~g}$ (S6). The granules were dried on trays at $40{ }^{\circ} \mathrm{C}$ for $24 \mathrm{~h}$.

In the second part of our work, during optimization of the granulation process, the quantities of the powder mixture and the liquid remained the same and the technical parameters were changed. The factorial design is a method that is often used to accelerate the solution of tasks. This method has been

\section{Table 3 - Levels of factors}

\begin{tabular}{lcc} 
Factor & Low-level (-) & High-level (+) \\
\hline Speed of the chopper (X1) & $1500 \mathrm{rpm}$ & $3500 \mathrm{rpm}$ \\
Speed of the impeller (X2) & $500 \mathrm{rpm}$ & $1000 \mathrm{rpm}$ \\
Dosing speed (X3) & $5 \mathrm{ml} / \mathrm{min}$ & $15 \mathrm{ml} / \mathrm{min}$ \\
Spheronization time (X4) & $1 \mathrm{~min}$ & $4 \mathrm{~min}$
\end{tabular}

applied in several branches of science and industry (food (de Assis et al., 2004), environmental management (Todorovic et al., 2003), chemistry (Forte et al., 2003), pharmaceutical technology (Sertsou et al., 2002; Khanvilkar et al., 2002; Gohel et al., 2003; Dévay et al., 1982)). A $2^{4}$ factorial design was applied to choose the relevant factors. The levels of the factors are to be found in Table 3. The experiments were performed in randomized sequence. This method can be utilized for evaluate interactions which can arise during direct compression. The following approach, containing the interactions of the factors, was used to determine the response surface and relative effect of factors $(b)$

$$
\begin{aligned}
y= & b_{0}+b_{1} X_{1}+b_{2} X_{2}+b_{3} X_{3}+b_{4} X_{4}+b_{12} X_{1} X_{2}+b_{13} X_{1} X_{3} \\
& +b_{23} X_{2} X_{3}+b_{14} X_{1} X_{4}+b_{24} X_{2} X_{4}+b_{34} X_{3} X_{4}+b_{123} X_{1} X_{2} X_{3} \\
& +b_{234} X_{2} X_{3} X_{4}+b_{124} X_{1} X_{2} X_{4}+b_{134} X_{1} X_{3} X_{4}
\end{aligned}
$$

Statistica for Windows 7.1 AGA sofware (StatSoft, Inc. Tulsa, USA) was used for the calculations. During the mathematical evaluations, the confidence interval was $95 \%$, i.e. the differences were significant if $p<0.05$.

\subsection{Characterization of granule size distribution}

The sizes and the size distributions of the samples were evaluated. An analytical sieve (Retsch $\mathrm{GmbH}$, Haan, Germany) was used. D50 was determined with sieving system software (Retsch EasySieve 2.0). Our previous experience had indicated that the granules must measure between 500 and $2000 \mu \mathrm{m}$ for the preparation of tablets. Hence, the waste consisted of the particles $<500 \mu \mathrm{m}$ or $>2000 \mu \mathrm{m}$.

\section{Results and discussion}

\subsection{Evaluation of water uptake}

The extents water uptake of the starting materials were measured before the evaluation of the powder mixtures. The highest quantity was detected for microcrystalline cellulose and the lowest for HPMC (Table 4). Gel-forming properties of the polymer were observed. A thin gel layer formed at the

Table 4 - Enslin numbers of samples

\begin{tabular}{lc} 
Sample & Enslin number $(\mathrm{ml} / \mathrm{g})$ \\
\hline Lactose & $0.3791 \pm 0.1276$ \\
Microcrystalline cellulose & $2.2361 \pm 0.0283$ \\
Mix0 & $1.1692 \pm 0.0428$ \\
Mix10 & $0.8822 \pm 0.0680$ \\
Mix20 & $0.4711 \pm 0.0184$ \\
Mix30 & $0.2553 \pm 0.0090$ \\
Mix40 & $0.1996 \pm 0.0141$ \\
Mix50 & $0.1945 \pm 0.0098$ \\
Mix100 (HPMC) & $0.1876 \pm 0.0229$
\end{tabular}




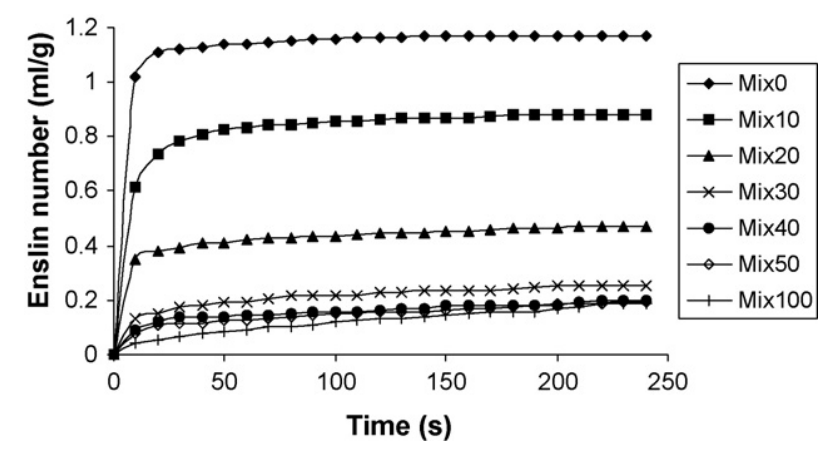

Fig. 1 - Wetting curves of the samples.

lower part of the powder. The values for the mixtures were intermediate between these results, but it can be seen that the changes in these parameters as the concentrations of the components were altered were not linear. At the lower concentrations of HPMC, a significant decrease was detected on $10 \%$ increase of this material. But a $10 \%$ increase of this component did not induce a relevant alteration for the samples containing a larger amount of HPMC.

The characteristics of the wetting curve were very similar for the powder mixtures, a slight difference being detected for HPMC (Fig. 1). In this case, the slope of the first part of the curve was lower than for the powder mixtures. The characteristic water uptake time (fitting was very good for every samples) of the Mix0 was the shortest (Table 5). The values of the shape parameters $(\beta)$ are $<1$, and thus the curves are saturation curves with a fast initial increase. The values of the scale parameter (a) indicates the speed of increasing of the curve. This parameter increased with higher amounts of matrix former. It can be concluded that not only the quantity of water, but also the speed of this process, was the lowest for HPMC. This is demonstrated by the gel-forming of the material and the barrier function of this gel layer.

\subsection{Erosion study of the matrices}

The change in the erosion times of the matrices with increase of the concentration of the matrix former was very relevant (Table 6). This can be seen at the lower concentrations of HPMC. The values for the samples containing at least $40 \%$ of matrix-forming macromolecules did not differ significantly from that for pure HPMC.

A connection was detected between the erosion times of the samples and the Enslin numbers (Fig. 2). An exponential decrease in the erosion time can be seen on increase of the quantity of water taken up. The behavior of polymer alone is

\section{Table 6 - Erosion times of compacts}

\begin{tabular}{lc} 
Sample & Erosion time (min) \\
\hline Mix0 & $0.11 \pm 0.01$ \\
Mix10 & $1.33 \pm 0.18$ \\
Mix20 & $25.60 \pm 6.97$ \\
Mix30 & $65.71 \pm 6.94$ \\
Mix40 & $89.06 \pm 7.00$ \\
Mix50 & $92.92 \pm 8.43$ \\
Mix100 (HPMC) & $89.49 \pm 7.55$ \\
\hline
\end{tabular}

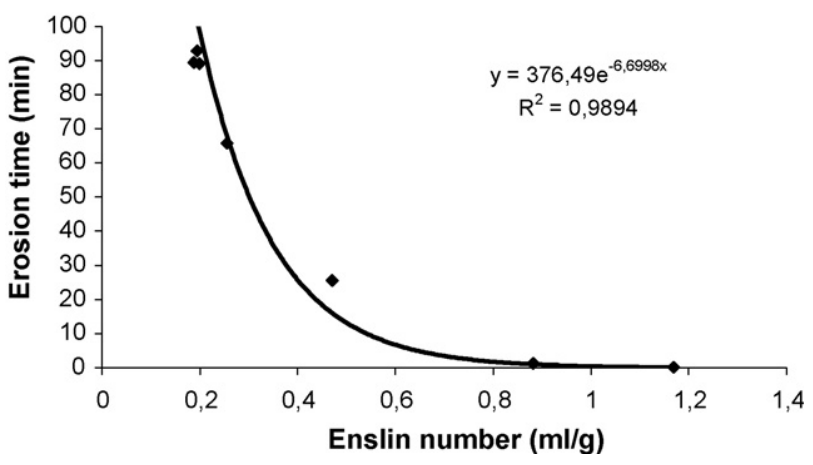

Fig. 2 - Comparison of Enslin number and erosion times of the samples.

very different from that of the matrix. The samples with $40 \%$ and $50 \%$ of HPMC exhibited very similar properties to those of pure HPMC. This is indicative of the even covering of the other particles by the HPMC.

The object of this work was the evaluation of the composition of products where the effects of the matrix former were relevant, but its properties differed significantly from those of HPMC. This was chosen on the basis of the results of the preformulation studies, which revealed that HPMC without other components (Mix100) is not appropriate for high-shear granulation. Adherence to the wall of the container and impeller was detected because of the gelforming properties and the adhesive behaviour of this layer. The samples containing 30\% of HPMC (Mix30) were therefore used in the subsequent part of our work.

\subsection{Determination of the optimum quantity of granulating fluid}

The chosen powder mixture was granulated with different quantities of water. The mean particle size of the granules (D50 value) increased, while, because of the small, the waste particles decreased. However, because of the large particles,

Table 5 - Characteristic time of water uptake of the samples

\begin{tabular}{lcccc} 
Sample & Characteristic water uptake time(s) & $\beta$ & $a$ & $R^{2}$ value \\
\hline Mix0 & 7.26 & 0.8500 & 7.15 & 0.9992 \\
Mix10 & 9.07 & 0.8333 & 9.59 & 0.9991 \\
Mix20 & 8.47 & 0.8100 & 11.84 & 0.9903 \\
Mix30 & 24.08 & 0.7980 & 15.74 & 0.9979 \\
Mix40 & 24.00 & 0.7884 & 17.63 & 0.9872 \\
Mix50 & 48.25 & 0.7812 & 19.73 & 0.9892 \\
Mix100(HPMC) & 99.01 & 0.7885 & 25.26 & 0.9753 \\
\hline
\end{tabular}




\section{Table 7 - Parameters of granules prepared with different quantities of water}

\begin{tabular}{|c|c|c|c|c|c|}
\hline \multirow[t]{2}{*}{ Notation } & \multirow[t]{2}{*}{ Water per $100 \mathrm{~g}$ of powder (g) } & \multirow[t]{2}{*}{$\mathrm{D} 50(\mu \mathrm{m})$} & \multicolumn{2}{|c|}{ Waste (\%) } & \multirow[t]{2}{*}{ Total waste (\%) } \\
\hline & & & $<500 \mu \mathrm{m}$ & $>2000 \mu \mathrm{m}$ & \\
\hline S1 & 20 & 461 & 54.3 & 1.8 & 56.1 \\
\hline $\mathrm{S} 2$ & 25 & 607 & 44.9 & 2.2 & 47.1 \\
\hline S3 & 27.5 & 660 & 41 & 2.7 & 43.7 \\
\hline S4 & 30 & 789 & 34.3 & 2.4 & 36.7 \\
\hline S5 & 35 & 974 & 16.5 & 5.2 & 21.7 \\
\hline S6 & 40 & 1834 & 0.5 & 40 & 40.5 \\
\hline
\end{tabular}

Table 8 - Parameters of granules with different operational parameters

\begin{tabular}{|c|c|c|c|c|c|}
\hline X1 (rpm) & X2 (rpm) & X3 (ml/min) & $\mathrm{X} 4$ (min) & D50 $(\mu \mathrm{m})$ & Total waste (\%) \\
\hline 3500 & 500 & 15 & 4 & 1222 & 15.4 \\
\hline 1500 & 500 & 5 & 1 & 1306 & 19.2 \\
\hline 1500 & 1000 & 15 & 1 & 918 & 25.2 \\
\hline 3500 & 1000 & 5 & 4 & 1232 & 19.7 \\
\hline 1500 & 500 & 15 & 1 & 1268 & 22.8 \\
\hline 1500 & 1000 & 15 & 4 & 976 & 19.2 \\
\hline 3500 & 1000 & 5 & 1 & 1306 & 18.3 \\
\hline 3500 & 1000 & 15 & 1 & 917 & 23.5 \\
\hline 1500 & 500 & 15 & 4 & 1306 & 19.4 \\
\hline 3500 & 1000 & 15 & 4 & 962 & 18.5 \\
\hline 3500 & 500 & 5 & 1 & 1284 & 22.5 \\
\hline 3500 & 500 & 5 & 4 & 1247 & 17.7 \\
\hline 1500 & 1000 & 5 & 1 & 1216 & 19.4 \\
\hline 1500 & 500 & 5 & 4 & 1333 & 19.5 \\
\hline 3500 & 500 & 15 & 1 & 1264 & 24.2 \\
\hline 1500 & 1000 & 5 & 4 & 1478 & 20.3 \\
\hline
\end{tabular}

the waste increased with higher amounts of liquid (Table 7). The total waste was lowest for the samples prepared with $35 \mathrm{~g}$ of water for $100 \mathrm{~g}$ of powder.

\subsection{Optimization of the granulation process}

A $2^{4}$ full factorial design was utilized to optimize the circumstances applied during granulation. The minimization of the waste was used as a determining parameter. The D50 values of the different charges varied between 917 and $1478 \mu \mathrm{m}$, and the total waste varied between 15.4 and $25.2 \%$ (Table 8). After determination of the response surface, the

\section{Table 9 - Values of coefficients}

\begin{tabular}{lrc} 
Coefficient & Value for D50 & Value for total waste \\
\hline b0 & 1202.19 & 20.30 \\
b1 & -22.94 & -0.33 \\
b2 & -76.56 & 0.21 \\
b3 & -98.06 & $0.73^{\mathrm{a}}$ \\
b4 & 17.31 & $-1.59^{\mathrm{a}}$ \\
b12 & 1.56 & -0.19 \\
b13 & 10.06 & -0.30 \\
b14 & -30.81 & -0.56 \\
b23 & -84.31 & 0.36 \\
b23 & 19.06 & 0.50 \\
b34 & -4.94 & $-1.31^{\mathrm{a}}$ \\
b123 & 7.56 & 0.21 \\
b124 & -12.81 & $0.75^{\mathrm{a}}$ \\
b134 & 19.19 & 0.01 \\
b234 & -5.69 & -0.35 \\
\hline
\end{tabular}

${ }^{a}$ Significant. fitting was very good $\left(R^{2}=0.9829\right)$ for the D50 value, but there was no significant factor (Table 9, Fig. 3). The largest effect was observed for X3 (dosing speed). Since the sign of this factor is negative, increase of the speed of dosing caused a decrease in the particle size.

The fitting of the response surface for the total waste was also very good $\left(R^{2}=0.9996\right)$ and there were four significant factors (Table 9, Fig. 4). Increase of the spheronization time significantly decreased the waste, and reduction of the dosing speed also minimized this parameter. There were two significant two-factor interactions. The significant factors were those which increased the process time.

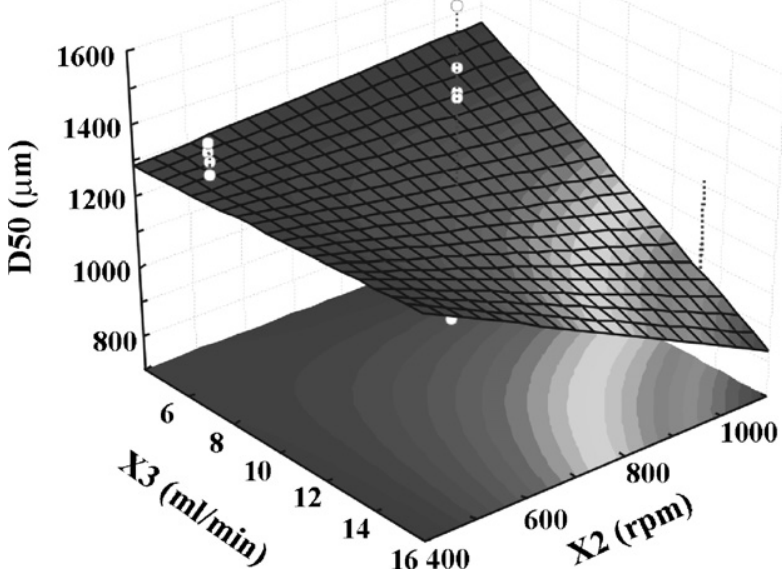

Fig. 3 - Response surface of $2^{4}$ full factorial design for D50 (roles of factors $\mathrm{X} 2$ and $\mathrm{X} 3$ if factor $\mathrm{X} 1$ and $\mathrm{X} 4$ ares at the zero level). 


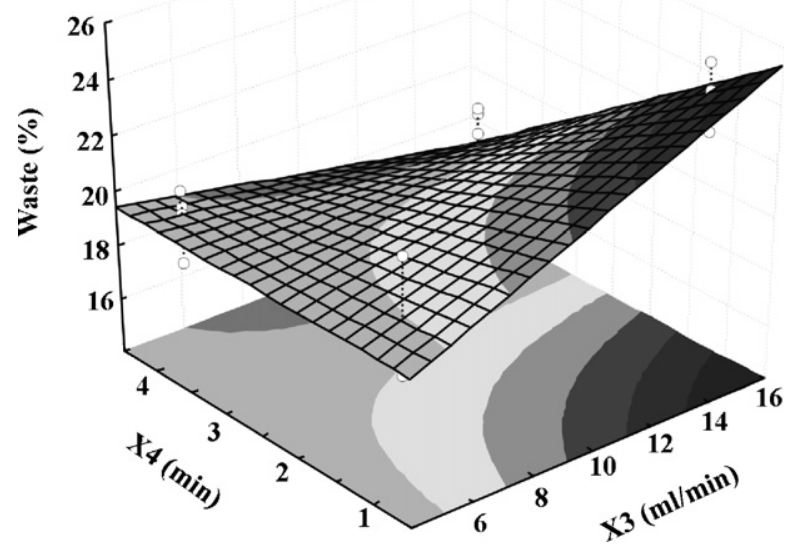

Fig. 4 - Response surface of $2^{4}$ full factorial design for total waste (roles of factors $\mathrm{X} 3$ and $\mathrm{X} 4$ if factor $\mathrm{X} 1$ and $\mathrm{X} 2$ ares at the zero level).

\section{Conclusion}

It can be concluded from the results that the water uptake (quantity and speed) was lowest for pure HPMC. Decrease of the concentration of the matrix former increased the water uptakes and decreased the erosion times of the matrix comprimates. There was a very good exponential correlation between the erosion times of the matrix comprimates and Enslin number of the powder mixtures. This relationship was an inverse one and tends to level off. The powder mixtures containing at least $40 \%$ of the matrix former HPMC exhibited very similar properties to those of HPMC.

When the matrix granules were prepared from the powder mixture with $30 \%$ of HPMC with different quantities of water in a high-shear granulator, the lowest amount of waste was detected for the samples produced with $35.0 \mathrm{~g}$ of water for $100 \mathrm{~g}$ of powder. A $2^{4}$ full factorial design was used to determine the optimum parameters of the granulation. A significantly lower amount of waste could be achieved with a long spheronization time and slow dosing. The speeds of the impeller and the chopper were not significant for these samples. This result was very interesting and unexpected, but it was supported by the wettability of the powder mixture. The poor water uptake and the gel-forming properties of HPMC are of the highest importance for the factors affecting the wettability of the powder mixture. For perfect wetting of the powder, a long time is necessary because of the slow penetration of the water across the formed gel layer of HPMC. Factors which increase the wetting time are therefore the relevant during the formulation of this system. The mechanical effects of the impeller and the chopper facilitate this process, but are less important in this case.

It can be concluded, that the testing of wetting properties are necessary for determination the best composition and conditions for the preparation of a matrix system containing HPMC as a gel-forming macromolecular component. The effect of the operational factors can be predicted from results of such preformulation studies. This work pointed out the importance of this step of optimization. Determination of the critical control points in the production of these systems is promoted by these tests.

\section{Acknowledgement}

This work was supported by Hungarian Scientific Research Fund (OTKA) grant F-049310.

\section{R E F E R E N C E S}

Aulton, M.E. 2002, Pharmaceutics, The Science of Dosage Form Design. London: Churcill Livingstone.

Baloğlu, E., Özyazıcı, M., Hızarcıŏlu, S.Y. and Karavana, H.A., 2003, An in vitro investigation for vaginal bioadhesive formulations: bioadhesive properties and swelling states of polymer mixtures, Il Farmaco, 58: 391-396.

Chien, Y.W. and Lee, C.H., 2002, Drug delivery-vaginal route, (2nd ed.). In Swarbrick, J., \& Boylan, J. C. Eds. Encyclopedia of Pharmaceutical Technology (vol. 1). New York: Marcel Dekker Inc.

das Neves, J. and Bahia, M.F., 2006, Gels as vaginal drug delivery systems, Int J Pharm, 318: 1-14.

Davies, B. and Ellis, S., 2005, Process analytical technology: the route to process understanding and control, Pharm Technol Eur, 17(7): 17-23.

de Assis, S.A., Ferreira, B.S., Fernandes, P., Guaglianoni, D.G. Cabral, J. M. S. and Oliveira, O. M. M. F. , 2004, Gelatinimmobilized pectinmethylesterase for production of low methoxyl pectin, Food Chem, 86: 333-337.

Dévay, A., Kovács, B., Uderszky, J. and Dömötör, Z., 1982, Multifactorial design optimization of film coating technique, Pharm Ind, 44: 830-833.

Forte, M. M. C., Cunha, F. O. V., Santos, J. H. Z. and Zacca, J.J., 2003, Ethylene and 1-butene copolymerization catalyzed by a Ziegler-Natta/metallocene hybrid catalyst through a $2^{3}$ factorial experimental design, Polymer, 44: 1377-1384

Gohel, M.C., Patel, M.M. and Amin, A.F., 2003, Development of modified release diltiazem $\mathrm{HCl}$ tablets using composite index to identify optimal formulation, Drug Dev Ind Pharm, 29: 565-574.

Hillary, A.M., Llojd, A.W. and Swarbrick, J., 2001, Drug Delivery and Targeting for Pharmacists on Pharmaceutical Scientists. London: Taylor\&Francis.

Hussain, A. and Ahsan, F., 2005, The vagina as a route for systemic drug delivery, J Control Rel, 103: 301-313.

Karasulu, H.Y., Hilmioğlu, S., Metin, D.Y. and Güneri, T., 2004, Efficacy of a new ketoconazole bioadhesive vaginal tablet on Candida albicans, Il Farmaco, 59: 163-167.

Kast, C.E., Valenta, C., Leopold, M. and Bernkop-Schnürch, A., 2002, Design and in vitro evaluation of a novel bioadhesive vaginal drug delivery system for clotrimazole, J Control Rel, 81: $347-354$.

Khanvilkar, K.H., Ye Huang, and Moore, A.D., 2002, Influence of hydroxypropyl methylcellulose mixture, apparent viscosity, and tablet hardness on drug release using a $2^{3}$ full factorial design, Drug Dev Ind Pharm, 28: 601-608.

Mullarney, M.P. and Hancock, B.C., 2006, Mechanical property anisotropy of pharmaceutical excipient compacts, Int J Pharm, 314: 9-14.

Nygaard, L., Kilde, H.D., Andersen, S.G., Henriksen, L. and Overby, V., 2004, Development and validation of a reversedphase liquid chromatographic method for analysis of degradation products of estradiol in Vagifem ${ }^{\circledR}$ tablets, $\mathrm{J}$ Pharmaceut Biomed Anal, 34: 265-276.

Parikh, D.M. 1995, Handbook of Pharmaceutical Granulation Technology. New York: Marcel Dekker Inc.

Ritschel, W.A. and Bauer-Brandl, A., 2002, Die Tablette, Editio Cantor Verlag, Aulendorf.

Rowe, R.C., Sheskey, P.J. and Weller, P.I., 2003, Handbook of Pharmaceutical Excipients (4th ed.). London: Pharmaceutical Press. 
Russo, E., Parodi, B., Caviglioli, G., Cafaggi, S., Bignandi, G., Milani, M. and Prini, M., 2004, Development, characterization and preliminary clinical evaluation of mucoadhesive vaginal gels containing chlorhexidine digluconate, J Drug Del Sci Technol, 14: 489-494.

Sertsou, G., Butler, J., Scott, A., Hempenstall, J. and Rades, T., 2002, Factors affecting incorporation of drug into solid solution with HPMC during solvent change co-precipitation, Int J Pharm, 245: 99-108.

Siepmann, J. and Peppas, N.A., 2001, Modeling of drug release from delivery systems based on hydroxypropyl methylcellulose (HPMC), Adv Drug Deliv Rev, 48: 139-157.

Takeuchi, H., Nagira, S., Yamamoto, H. and Kawashima, Y., 2004, Die wall pressure measurement for evaluation of compaction property of pharmaceutical materials, Int J Pharm, 274: 131-138.
Todorovic, J., Ecke, H. and Lagerkvis, A., 2003, Solidification with water as a treatment method for air pollution control residues, Waste Manage, 23: 621-629.

Valenta, C. 2005, The use of mucoadhesive polymers in vaginal delivery, Adv Drug Deliv Rev, 57: 1692-1712.

Vueba, M.L., Batista de Carvalho, L. A. E., Veiga, F., Sousa, J.J. and Pina, M.E., 2004, Influence of cellulose ether polymers on ketoprofen release from hydrophilic matrix tablets, Eur J Pharm Biopharm, 58: 51-59.

Weibull, W. 1951, A statistical distribution function of wide applicability, J Appl Mech, 18: 293-297.

Woolfson, A.D., Elliott, G. R. E., Gilligan, C.A. and Passmore, C.M., 1999, Design of an intravaginal ring for the controlled delivery of $17 \beta$-estradiol as its 3 -acetate ester, J Control Rel, 61: 319-328.

Woolfson, A.D., Malcolm, R.K. and Gallagher, R.J., 2003, Design of a silicone reservoir intravaginal ring for the delivery of oxybutynin, J Control Rel, 91: 465-476. 
II 


\title{
Evaluation of the composition of the binder bridges in matrix granules prepared with a small-scale high-shear granulator
}

\author{
János Bajdik ${ }^{\mathrm{a}}$, Gabriella Baki ${ }^{\mathrm{a}}$, Zsuzsanna Szent-Királlyi ${ }^{\mathrm{b}}$, Klaus Knop ${ }^{\mathrm{c}}$, \\ Peter Kleinebudde ${ }^{c}$, Klára Pintye-Hódi ${ }^{\mathrm{a}, *}$ \\ a Department of Pharmaceutical Technology, University of Szeged, Eötvös u. 6, H-6720 Szeged, Hungary \\ ${ }^{\mathrm{b}}$ EGIS Pharmaceuticals PLC, Keresztúri út 30-38, H-1106 Budapest, Hungary \\ ' Institute of Pharmaceutics and Biopharmaceutics, Heinrich-Heine University, Universitätsstr. 1, D-40225 Düsseldorf, Germany
}

\section{A R T I C L E I N F O}

\section{Article history:}

Received 10 March 2008

Received in revised form 19 May 2008

Accepted 29 June 2008

Available online 6 July 2008

\section{Keywords}

High-shear granulator

Lactose monohydrate

Small-scale

Thermomechanical analysis

X-ray diffraction

\begin{abstract}
A B S T R A C T
The aim of this work was to evaluate the binder bridges which can form in hydrophilic matrix granules prepared with a small-scale high-shear granulator. Matrices contained hydroxypropyl methylcellulose (HPMC) as a matrix-forming agent, together with lactose monohydrate and microcrystalline cellulose as filler. Water was used as granulating liquid. A $2^{4}$ full factorial design was used to evaluate the effects of the operational parameters (impeller speed, chopper speed, dosing speed and wet massing time) on the granulation process. The temperature of the sample increased relevantly during the preparation in the small-scale apparatus. The same setup induced different temperature increases for different amounts of powder. This alteration enhances the solubility of lactose and decreases that of HPMC, and thus the quantities of the dissolved components can vary. Accordingly, changes in composition of the binder bridge can occur. Since exact determination of the dissolution of these materials during granulation is difficult, the consequences of the changes in solubility were examined. Differential scanning calorimetry (DSC), thermomechanical analysis (TMA) and X-ray diffraction (XRD) measurements were made to evaluate the films prepared from liquids with different ratios of soluble materials. The DSC and XRD measurements confirmed that the lactose lost its crystalline state in the film. The TMA tests revealed that increase of the quantity of lactose in the film decreased the glass transition temperature of the film; this may be attributed to the interaction of the additives. At a lactose content of $37.5 \%$, a second glass transition appeared. This phenomenon may be indicative of a separate amorphous lactose phase.
\end{abstract}

(c) 2008 Elsevier B.V. All rights reserved.

\section{Introduction}

Various solid matrix systems are currently popular because of their controlling effects on the dissolution of the active ingredients $[1,2]$. These matrices (mainly tablets) may be hydrophobic or hydrophilic. Hydrophilic systems can influence the rate of liberation of active pharmaceutical ingredient (API) by erosion and diffusion [3-5], but they can also exhibit relevant bioadhesive properties which can affect the site of action [6,7]. The matrix-formers that are mainly used for erodable systems are polymers with good solubility, high water uptake and properties appropriate for the formation a mucilaginous (adhesive) layer. The additional pharmaceutical excipients must be hydrophilic so as to avoid inappropriate wetting of the matrix-former and to promote the action of the matrix-former polymer.

\footnotetext{
* Corresponding author. Tel.: +36 62545576; fax: +36 62545571.

E-mail address: klara.hodi@pharm.u-szeged.hu (K. Pintye-Hódi).
}

Tablets can be prepared through the direct compression of a powder mixture containing a matrix-former or through the compression of granules (generally the matrix granules) [8]. Various methods can be used to prepare granules containing the previously mentioned components [9-12]. The most widely applied method is wet granulation, where the granulating fluid is an aqueous system. The granulating fluid can contain different binder materials (mainly macromolecular agents) or it can be a solvent of the solid component, in which case the soluble and later the solidified component too form bridges between the particles and ensure the appropriate mechanical behaviour for the agglomerates [13]. The soluble component can be any member of the powder mixture, e.g. the active agent, filler, matrix-former, etc., or a mixture of them. A number of publications have demonstrated that excipients that are strongly soluble in the liquid binder play a major role in the formation and strength of solid bridges inside a granule [14-16]. Those studies additionally dealt with the evaluation of the binder bridges, focusing on the mechanical and morphological properties of the granules, but not on the exact composition of binder 
bridges. Other papers discuss the evaluation of the solubilities of the materials, the crystallization/recrystallization processes and examination of the product formed with respect to amorphism and polymorphism [17-19]. Study of the composition and crystalline state of these individual small bridges in the granules is difficult, but an understanding of their formation is critical for optimization of the granulation process. The significance of such evaluations is highlighted by the well-known phenomenon that an amorphous form can change during storage and can indicate stability problems [20].

It was mentioned above that the hydrophilic matrix-former component can be water-soluble. Conventionally, various polysaccharides/polymers are used in the tablet formulations to retard drug release. A solution of such materials (e.g. different cellulose derivatives) is often used as a coating material. Alternatively, these can be used as a binder during conventional wet granulation binders [21,22]. It is known that a solution of these polysaccharides/polymers as binders probably on drying enables the granules to be coated by them [23] and the course of drying, they form hard film bridges [24-27]. In general, these materials are applied in high concentrations in the powder mixture during the formulation of matrix systems. A proportion of these materials dissolves in the granulation liquid and so a film or binder bridges are formed during drying, but prediction of the exact quantities is difficult. Another problem inherent in the prediction is the fact that the powder mixtures contain materials with different water uptakes and solubilities. The dissolved amounts of the components can be influenced by the quantity of the liquid and also by the operational parameters, e.g. the effectiveness of mixing or the processing time. The effects of the operational parameters on the granules or pellets formed have been studied [28-30], but the composition of the binder bridges (film) has not been evaluated.

The high-speed moving of the parts of a small-scale high-shear granulator (impeller and chopper) can cause a relevant increase in the temperature of the powder/granules. This parameter can therefore be an indirect factor during the optimization. Its importance is emphasized by the temperature-sensitive nature of the solubility of the components. In the composition under evaluation, not only the rate of dissolution, but also the quantity of materials dissolved can depend on the temperature. Hence the solution formed during granulation and after drying in the binder film can exhibit different compositions. Since exact, direct measurement of the components in the fluid formed around the solid particles and in wet granules appears impossible, it is reasonable to prepare and study the properties of free films formed from different ratios of the soluble components.

Pressures to save API are driving formulation developers toward smaller-scale laboratory processes (miniaturization), while pressure to save time puts a premium on increasingly accurate laboratory-scale tools. An appreciable number of manuscripts have dealt with miniaturization of the different technological methods and its problems [31-34]. In certain cases, it is very difficult to extrapolate the results to larger systems.

In the present work the effect of operational parameters and batch size on the temperature increase during small-scale granulation were studied. Since the solubilities of the components may

Table 1

Values of factors

\begin{tabular}{lcc}
\hline Factor & Low-level $(-)$ & High-level $(+)$ \\
\hline Chopper speed, $X_{1}(\mathrm{rpm})$ & 1500 & 3500 \\
Impeller speed, $X_{2}(\mathrm{rpm})$ & 500 & 1000 \\
Dosing speed, $X_{3}(\mathrm{ml} / \mathrm{min})$ & 5 & 15 \\
Wet massing time, $X_{4}(\mathrm{~min})$ & 1 & 4 \\
\hline
\end{tabular}

change as a result of this, the main aim was the evaluation of binder bridges with different ratios of soluble materials. Such data can be informative as concerns granulation scale-up.

\section{Experimental}

\subsection{Materials}

HPMC (Pharmacoat 606, Shin-Etsu Chemical Co., Ltd., Tokyo, Japan) was used as matrix-former. Our preformulation studies indicated that the optimum concentration was 30\%. Microcrystalline cellulose (Vivapur 301, Rettenmaier\&Söhne GmbH, Rosenberg, Germany) was applied as a filler/binder, and $\alpha$-lactose monohydrate (Ph. Eur., Hungaropharma Plc., Budapest) as a filler, each of these components was in a quantity of $35 \%$.

\subsection{Preparation of matrix granules}

In the first part of the granulation, $150 \mathrm{~g}$ of granules was prepared in a high-shear granulator (ProCepT 4M8 granulator, ProCepT nv, Zelzate, Belgium). This apparatus is equipped with an Infrared product temperature sensor assembly. It ensures a constant control between $20^{\circ} \mathrm{C}$ and $100^{\circ} \mathrm{C}$. In accordance with our previous results [35], the quantity of liquid (water) was 35-100 $\mathrm{g}$ of powder mixture.

During the optimization of the granulation process, the quantities of the powder mixture and the liquid were kept the same, and the technical parameters were varied. A $2^{4}$ factorial design was applied to study the effects of the operational factors (Table 1). The experiments were performed in a randomized sequence. The granules were dried on trays at $40^{\circ} \mathrm{C}$ for $24 \mathrm{~h}$.

Statistica for Windows 7.1 AGA software (StatSoft Inc., Tulsa, USA) was used for the calculations. The following linear approach, containing the interactions of the factors, was used to determine the response surface. This program can also evaluate three-factor interactions, but in this study they were not investigated. They are very difficult to interpret.

$$
\begin{aligned}
y= & b_{0}+b_{1} X_{1}+b_{2} X_{2}+b_{3} X_{3}+b_{4} X_{4}+b_{12} X_{1} X_{2}+b_{13} X_{1} X_{3}+b_{23} X_{2} X_{3} \\
& +b_{14} X_{1} X_{4}+b_{24} X_{2} X_{4}+b_{34} X_{3} X_{4}
\end{aligned}
$$

The confidence interval in the mathematical evaluations was $95 \%(p<0.05)$.

In the second part of our work, the effect of the batch size was evaluated. The same apparatus was used. The composition of the powder mixture was the same and the quantity of water was again 35-100 $\mathrm{g}$ of powder mixture. The operational parameters were-chopper speed: $3500 \mathrm{rpm}$; impeller speed: $1000 \mathrm{rpm}$; dosing speed: $5 \mathrm{ml} / \mathrm{min}$; and wet massing time: $4 \mathrm{~min}$. The amounts of powder taken were $50 \mathrm{~g}, 100 \mathrm{~g}, 150 \mathrm{~g}$ and $200 \mathrm{~g}$. The dosing time had to be adjusted.

\subsection{Study of granules}

The sizes and the size distributions of the samples were assessed. An analytical sieve (Retsch $\mathrm{GmbH}$, Haan, Germany) was used. The D10, D50 and D90 values of the samples were determined with sieving system software (Retsch EasySieve 2.0).

\subsection{Evaluation of the films}

Different samples were prepared for the thermoanalytical tests on the free film. Aqueous solutions containing various ratios of HPMC and lactose were produced (Table 2). They were poured into teflon dishes, and the solutions were then dried under the same 
Table 2

Compositions of samples

\begin{tabular}{|c|c|c|c|c|c|}
\hline Sample & Sign of dried film & HPMC content (\%) & Lactose content (\%) & HPMC/lactose ratio & Water (\%) \\
\hline S1 & F1 & 5 & 0 & - & 95 \\
\hline $\mathrm{S} 2$ & F2 & 5 & 1 & 5 & 94 \\
\hline S3 & F3 & 5 & 2 & 2.5 & 93 \\
\hline S4 & F4 & 5 & 3 & 1.67 & 92 \\
\hline S5 & F5 & 5 & 4 & 1.25 & 91 \\
\hline
\end{tabular}

conditions at $40 \pm 2{ }^{\circ} \mathrm{C}$ for $24 \mathrm{~h}$. The dried films were detached from the surface before the experiments and stored in a hermetically closed container.

The thermoanalytical examinations were carried out in part with a Mettler-Toledo DSC 821e (Mettler-Toledo GmbH, Switzerland) instrument with a dynamic method in the interval $25-300^{\circ} \mathrm{C}$, at a heating rate of $10^{\circ} \mathrm{C} / \mathrm{min}$. Argon was used as purge gas.

For a more accurate evaluation of the behaviour of the polymer film (glass transition), thermomechanical analysis TMA was performed with a Metler Toledo TMA 40 apparatus. The heating method was dynamic in the interval $20-200^{\circ} \mathrm{C}$, and the heating rate was $10^{\circ} \mathrm{C} / \mathrm{min}$. The glass transition temperature $\left(T_{\mathrm{g}}\right)$ was studied with STAR software. The measurements were made in triplicate.

\subsection{X-ray diffraction (XRD) testing}

A Bruker D8 Advance powder diffractometer (Bruker-AXS; Karlsruhe, Germany) was used for these tests. The non-pulverized samples were measured in transmission mode between Mylar foils $(3.6 \mu \mathrm{m})$, the following conditions being applied at room temperature.

Radiation : $\quad \operatorname{Cu} K \alpha 1(\lambda=1.54060 \AA)$ and $\mathrm{Cu} K \alpha 2(\lambda=1.54439 \AA)$

The attachments were a Göbel mirror, a Soller slit, and a 9position sample changer used in transmission mode. The voltage was $40 \mathrm{kV}$, the current was $30 \mathrm{~mA}$, and measurements involved a $\Theta / \Theta$ scan of $4-35.00^{\circ} 2 \Theta$, with a step size of $0.04^{\circ} 2 \Theta$.

\section{Results and discussion}

\subsection{Granulation experiments}

The sieving results on the granules revealed that the characteristic of particle size distribution of granules was very similar (Table 3 ). Apart from the fact that operational parameters were variant the differences between D10 and D90 were nearly $1500 \mu \mathrm{m}$.
The change of the operational factors caused an appreciable deviation in the median particle size. The D50 values of the different batches varied between $917 \mu \mathrm{m}$ and $1478 \mu \mathrm{m}$.

The temperature increase during the granulation process also exhibited a great variance $\left(4.8-18.6^{\circ} \mathrm{C}\right)$. The variation in this parameter is significant in changing the solubility of a component, e.g. the solubility of lactose is 1 part in 4.63 parts of water at $20^{\circ} \mathrm{C}$ and 1 part in 2.04 parts of water at $50^{\circ} \mathrm{C}$. The concentration of the saturated solution is therefore $17.8 \%$ at $20^{\circ} \mathrm{C}$ and $32.9 \%$ at $50{ }^{\circ} \mathrm{C}$ [36].

The model for the D50 value gave $R^{2}=0.959$ and three significant factors $(p<0.05)$ (Table 4$)$. The largest effect was observed for the dosing speed $\left(X_{3}\right)$. Since the sign of this factor was negative, increase of the dosing speed caused a decrease in the particle size.

The fitting of the response surface for the temperature increase resulted in a model with $R^{2}=0.982$ and four significant factors $(p<0.05)$. Increase of the impeller speed significantly enhanced the temperature increase which was alo increased by a reduction of the dosing speed. It was clear from the evaluation of all of the factors that an increased process time caused increases in the particle size and the temperature of the sample.

To investigate the effect of the amount of powder, independent tests were performed. It was seen that an increasing amount of

\section{Table 4}

Values of coefficients

\begin{tabular}{lcc}
\hline Coefficient & D50 & Temperature increase \\
\hline $\mathrm{b}_{0}$ & $1202.19^{\mathrm{a}}$ & $9.23^{\mathrm{a}}$ \\
$\mathrm{b}_{1}$ & -22.94 & 0.38 \\
$\mathrm{~b}_{2}$ & $-76.56^{\mathrm{a}}$ & $2.79^{\mathrm{a}}$ \\
$\mathrm{b}_{3}$ & $-98.06^{\mathrm{a}}$ & $-2.01^{\mathrm{a}}$ \\
$\mathrm{b}_{4}$ & 17.31 & $1.02^{\mathrm{a}}$ \\
$\mathrm{b}_{12}$ & 1.56 & 0.22 \\
$\mathrm{~b}_{13}$ & 10.06 & -0.06 \\
$\mathrm{~b}_{14}$ & -30.81 & 0.42 \\
$\mathrm{~b}_{23}$ & $-84.31^{\mathrm{a}}$ & $-1.19^{\mathrm{a}}$ \\
$\mathrm{b}_{24}$ & 19.06 & 0.43 \\
$\mathrm{~b}_{34}$ & -4.94 & -0.07 \\
\hline
\end{tabular}

a Significant

Table 3

Granulation parameters (in order of trials)

\begin{tabular}{|c|c|c|c|c|c|c|c|c|}
\hline$X_{1}(\mathrm{rpm})$ & $X_{2}(\mathrm{rpm})$ & $X_{3}(\mathrm{ml} / \mathrm{min})$ & $X_{4}(\min )$ & $\mathrm{D} 10(\mu \mathrm{m})$ & $\mathrm{D} 50(\mu \mathrm{m})$ & $\mathrm{D} 90(\mu \mathrm{m})$ & $\mathrm{D} 90-\mathrm{D} 10(\mu \mathrm{m})$ & Temperature increase $\left({ }^{\circ} \mathrm{C}\right)$ \\
\hline 3500 & 500 & 15 & 4 & 389 & 1222 & 1879 & 1490 & 7.3 \\
\hline 1500 & 500 & 5 & 1 & 367 & 1306 & 1932 & 1565 & 7.7 \\
\hline 1500 & 1000 & 15 & 1 & 236 & 918 & 1879 & 1643 & 7.5 \\
\hline 3500 & 1000 & 5 & 4 & 540 & 1232 & 2199 & 1659 & 18.6 \\
\hline 1500 & 500 & 15 & 1 & 284 & 1268 & 1922 & 1638 & 4.8 \\
\hline 1500 & 1000 & 15 & 4 & 359 & 976 & 1906 & 1547 & 9.7 \\
\hline 3500 & 1000 & 5 & 1 & 532 & 1306 & 2039 & 1507 & 13.8 \\
\hline 3500 & 1000 & 15 & 1 & 246 & 917 & 1864 & 1618 & 8.0 \\
\hline 1500 & 500 & 15 & 4 & 347 & 1306 & 1922 & 1575 & 5.6 \\
\hline 3500 & 1000 & 15 & 4 & 346 & 962 & 1887 & 1541 & 10.1 \\
\hline 3500 & 500 & 5 & 1 & 315 & 1284 & 1943 & 1628 & 6.1 \\
\hline 3500 & 500 & 5 & 4 & 464 & 1247 & 1930 & 1466 & 8.2 \\
\hline 1500 & 1000 & 5 & 1 & 498 & 1216 & 1988 & 1490 & 13.0 \\
\hline 1500 & 500 & 5 & 4 & 467 & 1333 & 1981 & 1514 & 7.0 \\
\hline 3500 & 500 & 15 & 1 & 257 & 1264 & 1915 & 1658 & 4.8 \\
\hline 1500 & 1000 & 5 & 4 & 623 & 1478 & 2396 & 1773 & 15.5 \\
\hline
\end{tabular}




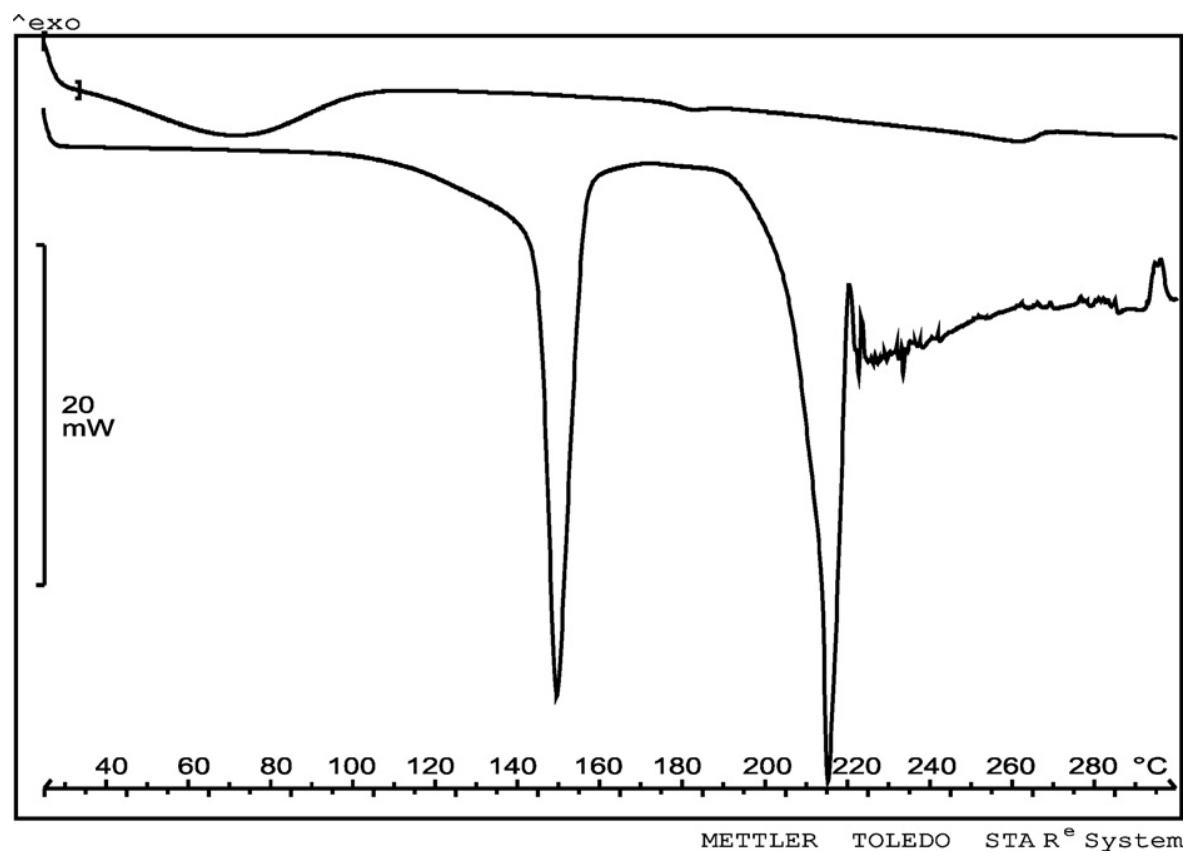

Fig. 1. DSC plot of HPMC (upper curve) and lactose monohydrate (lower curve).

powder mixure induced an increase in the dosing time (Table 5). The temperature increase was more relevant for the process with a long dosing time (higher amount of mass).

\subsection{Evaluation of the films}

Variation in the temperature of the sample can change the quantity and the proportions of the dissolved components, phenomena which can alter the properties of the film or binder bridge. Hence films with different compositions were prepared and evaluated.). The XRD curves of the films are typical for amorphous materials (Fig. 5

The starting components were studied first. A characteristic thermogram was observed for lactose monohydrate (Fig. 1). There was an endotherm peak at about $150^{\circ} \mathrm{C}$; this reflected the loss of crystalline water [37]. The other peak related to the melting of lactose. Above this temperature, the lactose decomposed. The differential scanning calorimetry (DSC) curve of the HPMC in this range was free from characteristic peaks. A wide endothermic peak

Table 5

Temperature increase of different samples

\begin{tabular}{lll}
\hline Amount of powder $(\mathrm{g})$ & Dosing time $(\mathrm{s})$ & Temperature increase $\left({ }^{\circ} \mathrm{C}\right)$ \\
\hline 50 & 210 & 8.6 \\
100 & 350 & 13 \\
150 & 630 & 18.6 \\
200 & 840 & 24.7 \\
\hline
\end{tabular}

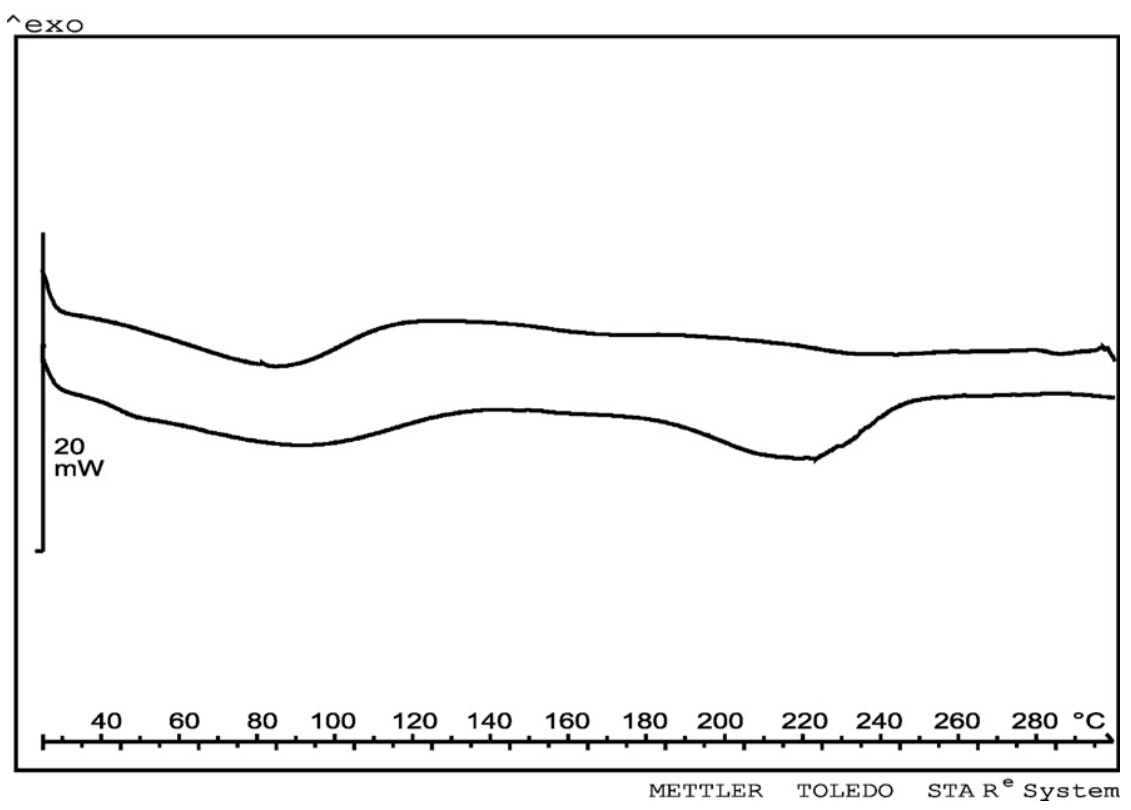

Fig. 2. DSC plots of F1 (upper curve) and F5 (lower curve). 


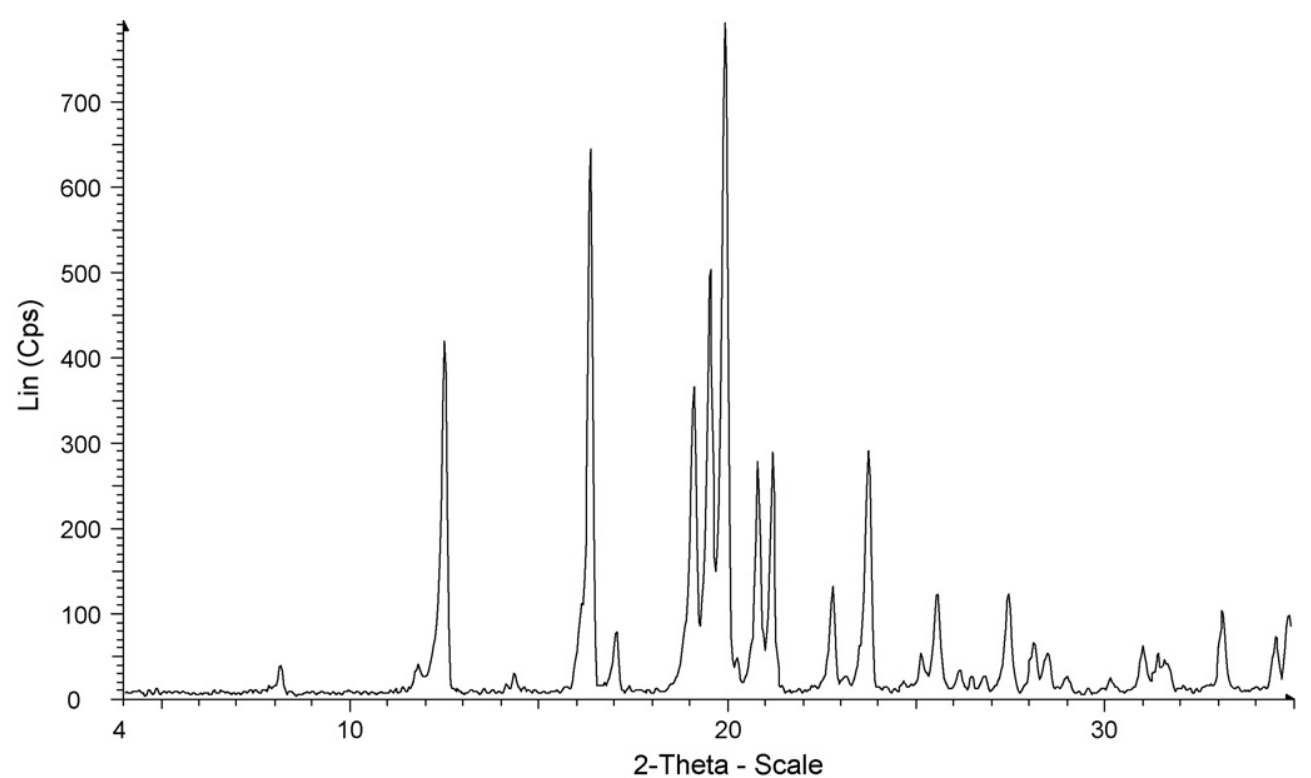

四 Lactosum monohydricum - File: lact008.raw - Type: 2 Th/Th locked - Start: $4.000^{\circ}$ - End: $35.000^{\circ}$ - Step: $0.040^{\circ}$ - Step time: 1. s - Temp.: $25^{\circ} \mathrm{C}$ (Room) - Time Started: $7 \mathrm{~s}$ - 2-Theta: $4.000^{\circ}$ - T Operations: Smooth 0.080 | Import

Fig. 3. XRD record of lactose monohydrate.

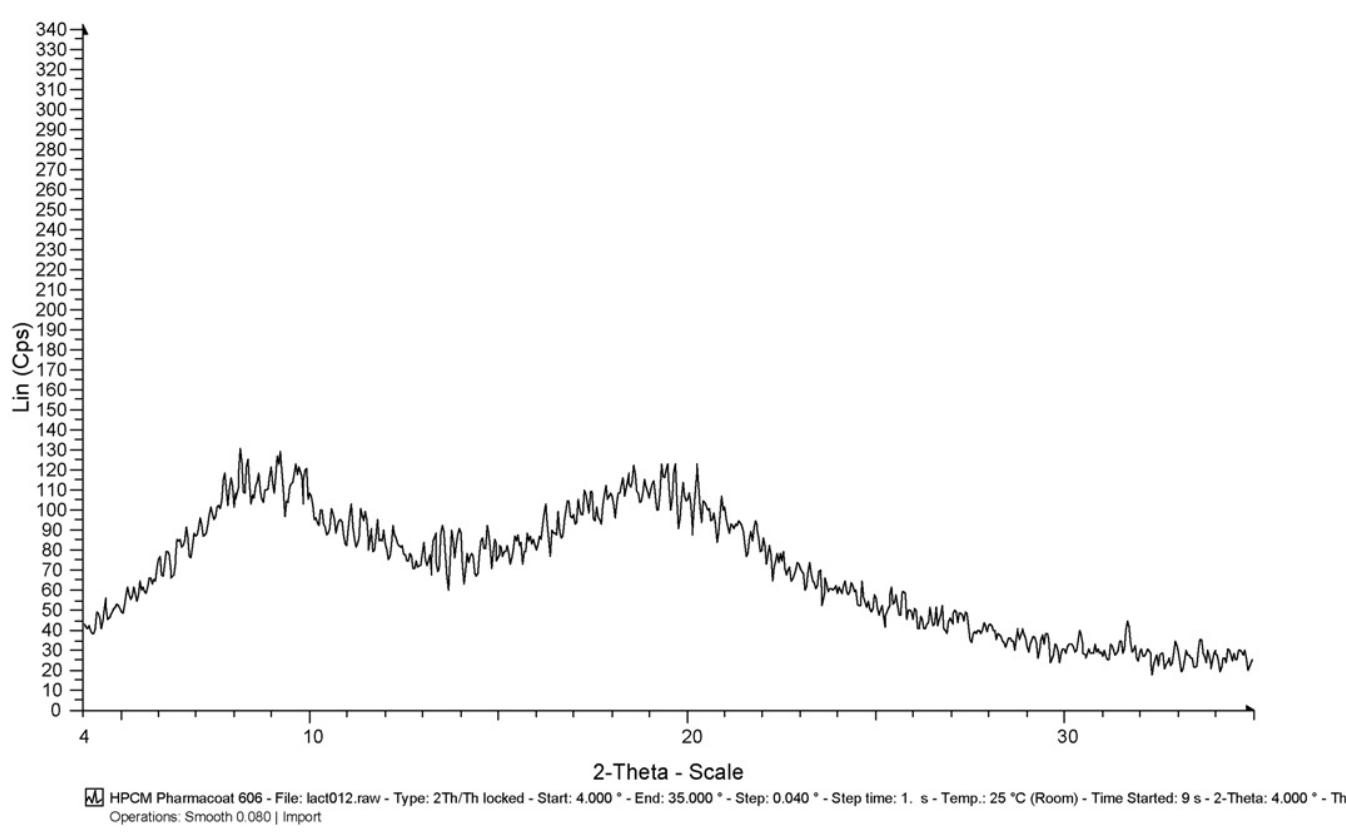

Fig. 4. XRD record of HPMC

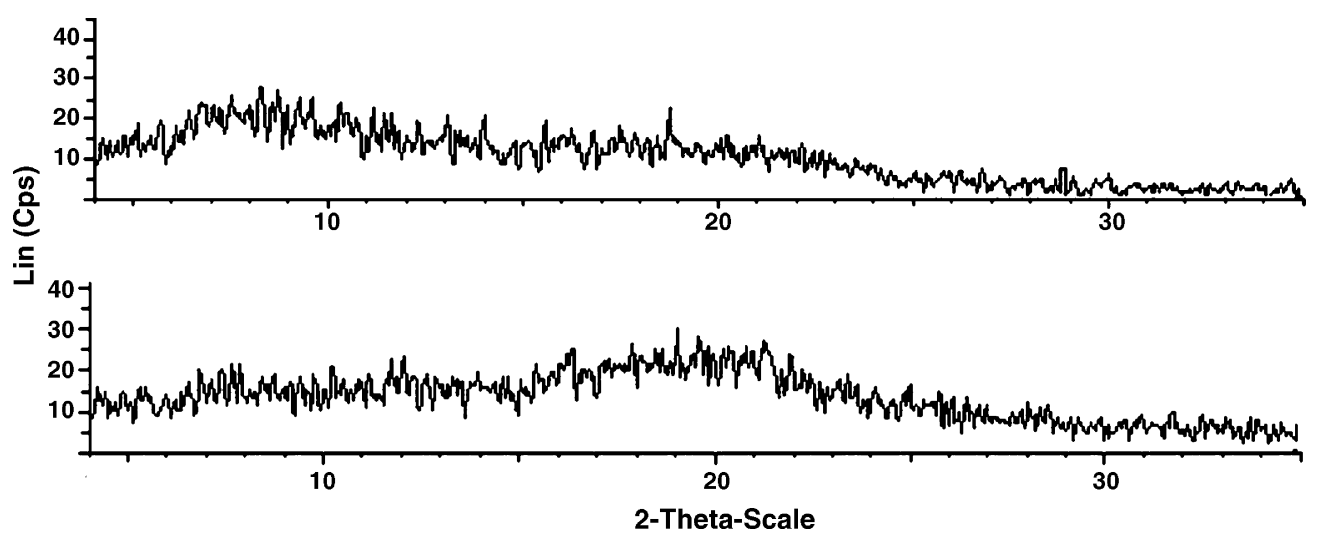

Fig. 5. XRD records of F1 (upper curve) and F5 (lower curve). 


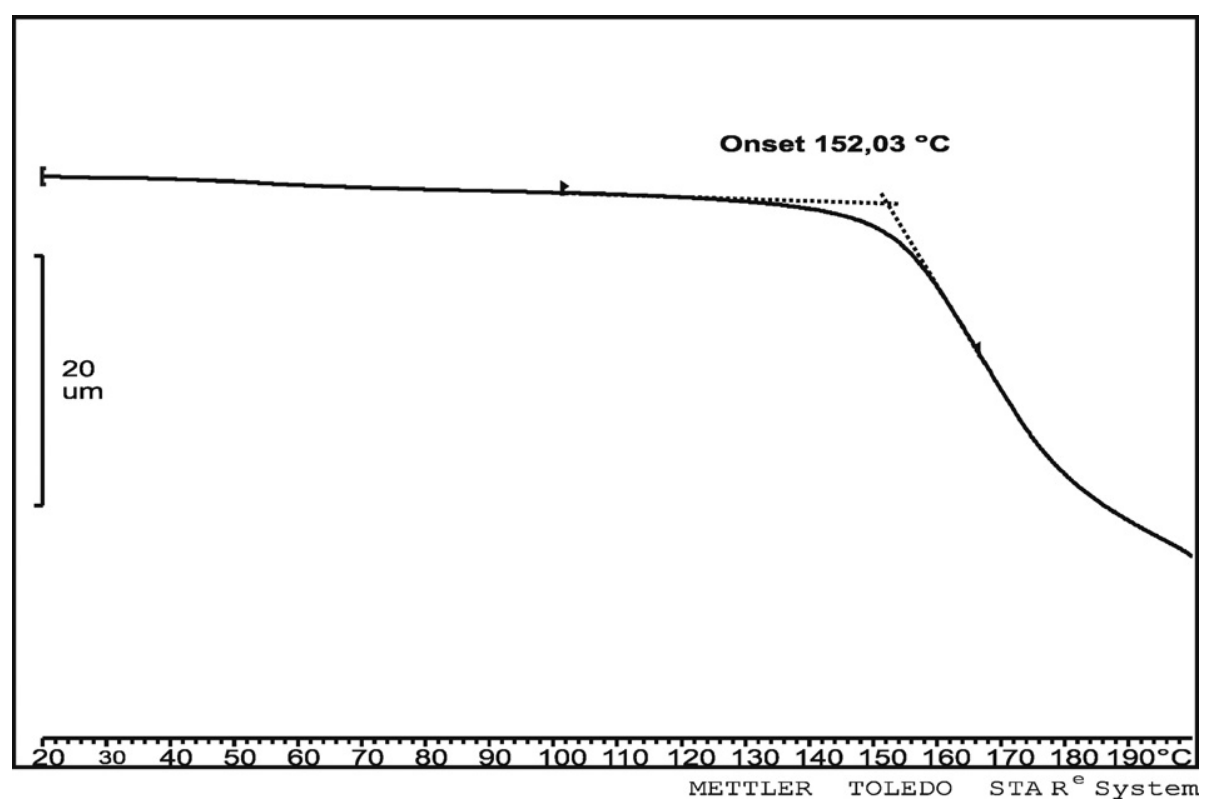

Fig. 6. TMA plot of F1.

under $100^{\circ} \mathrm{C}$ can be explained by the loss of mechanically bounded water. A slight shifting of baseline was detected at higher temperature. It was the $T_{\mathrm{g}}$ of polymer.

The DSC experiments indicated similar behaviour for all films. The curves of F1 and F5 are presented in Fig. 2. The sharp characteristic peaks of lactose disappeared, but no obvious endothermic phenomenon was detected at around $210^{\circ} \mathrm{C}$ for F5. Thus, the crystalline state of the lactose had evidently been lost.

XRD is a method with which to evaluate the crystallinity of the components. The crystalline state of lactose and the amorphous properties of HPMC can be seen from the curves of the starting components (Figs. 3 and 4).

Amorphous materials can be evaluated well with TMA. The TMA curve of HPMC exhibited a typical step relating to the glass tran- sition of amorphous material (Fig. 6). At temperatures below $T_{\mathrm{g}}$, the plot was linear. Deviation from linearity occurred as $T_{\mathrm{g}}$ was approached (onset temperature). As the temperature was increased further, the profile again became linear, indicating complete conversion to the rubbery phase. This process can be regarded as a shifting of the baseline. A change in composition altered the TMA curve of the film (Figs. 7 and 8). It can be seen that a second $T_{g}$ appeared for F4 and F5.

The temperatures of onset of $T_{\mathrm{g}}$ are listed in Table 6 . A decrease in the $T_{\mathrm{g}}$ of HPMC was detected for F2 and F3. Their values increased when the second step appeared for F4, and decreased for F5. These results can be interpreted in terms of changes in the structure of the film. For F2 and F3, the macromolecules and the lactose can interact, and the properties of the film then change. For F4 and F5, besides

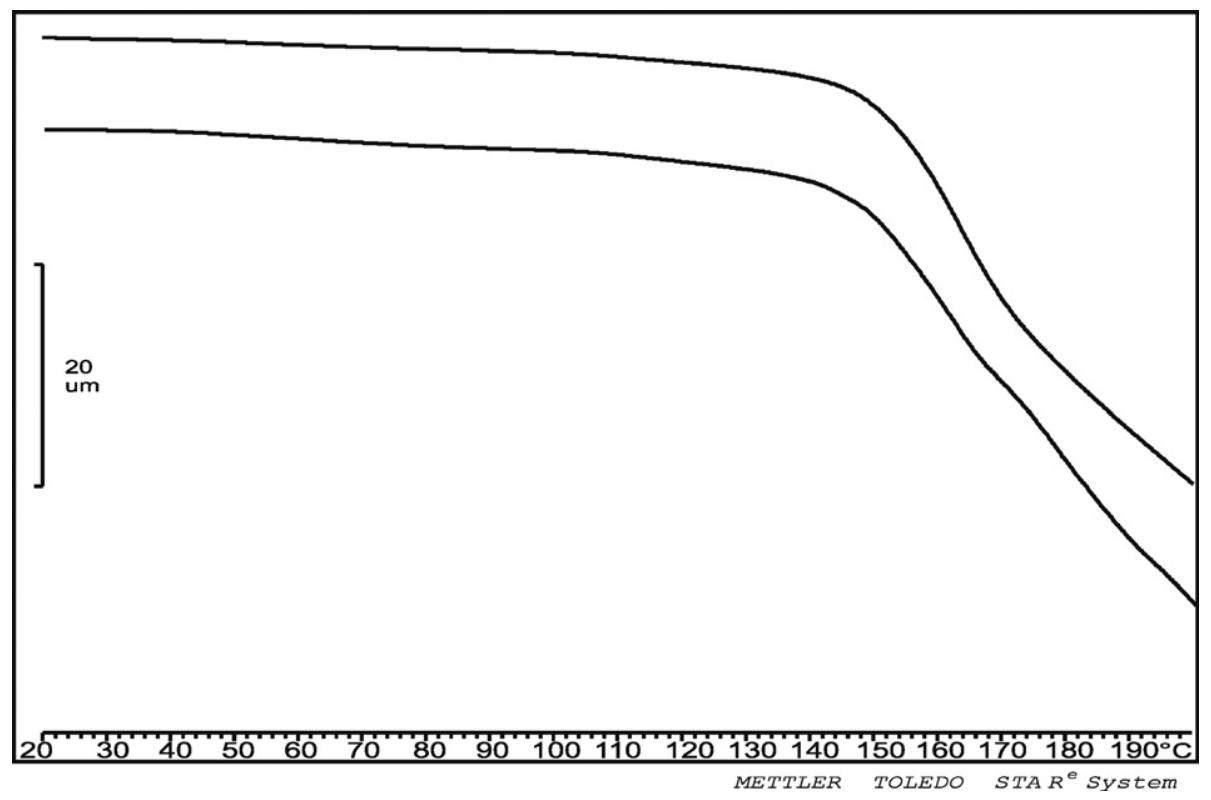

Fig. 7. TMA plots of F2 (upper curve) and F3 (lower curve). 


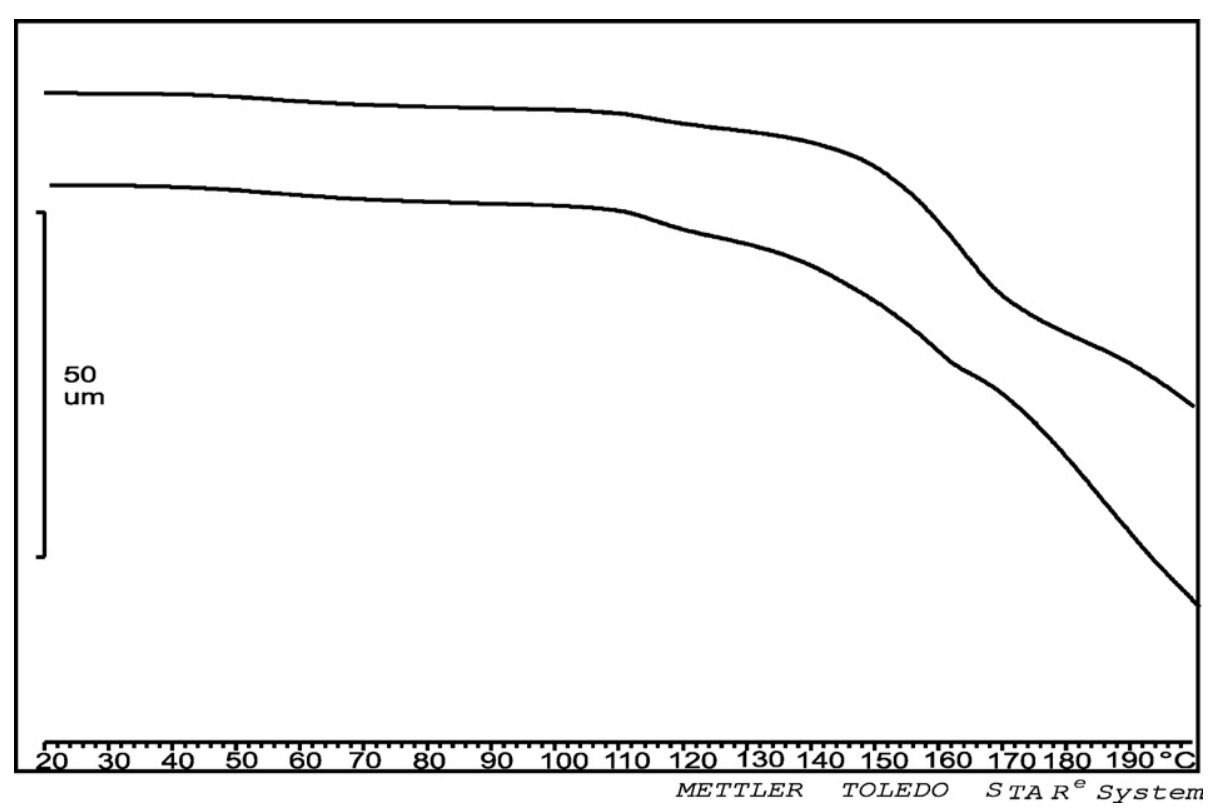

Fig. 8. TMA plots of F4 (upper curve) and F5 (lower curve).

such interactions, a new amorphous phase with a $T_{\mathrm{g}}$ appeared. It is known from the literature that the $T_{\mathrm{g}}$ of amorphous lactose is $100-120^{\circ} \mathrm{C}$, depending on the methods and conditions [38-40]. Hence, the second step probably relates to a separate amorphous lactose phase. It is well-known that the proportion of ordered and amorphous regions determines the mechanical properties of a macromolecular film [41]. The different phases can be detected in the film, as they induce inhomogeneity in it. It is also known that amorphous materials are less stable than crystalline ones and the stabilization of amorphous materials is very difficult [42].

\section{Table 6}

Temperatures of onset of glass transition $(n=3)$

\begin{tabular}{llc}
\hline Film & $T_{\mathrm{g}} 1\left({ }^{\circ} \mathrm{C}\right)$ & $T_{\mathrm{g}} 2\left({ }^{\circ} \mathrm{C}\right)$ \\
\hline F1 & $152.9 \pm 1.0$ & - \\
F2 & $150.4 \pm 1.2$ & - \\
F3 & $147.1 \pm 0.6$ & - \\
F4 & $150.9 \pm 0.8$ & $108.3 \pm 0.2$ \\
F5 & $143.3 \pm 0.9$ & $108.6 \pm 0.5$ \\
\hline
\end{tabular}
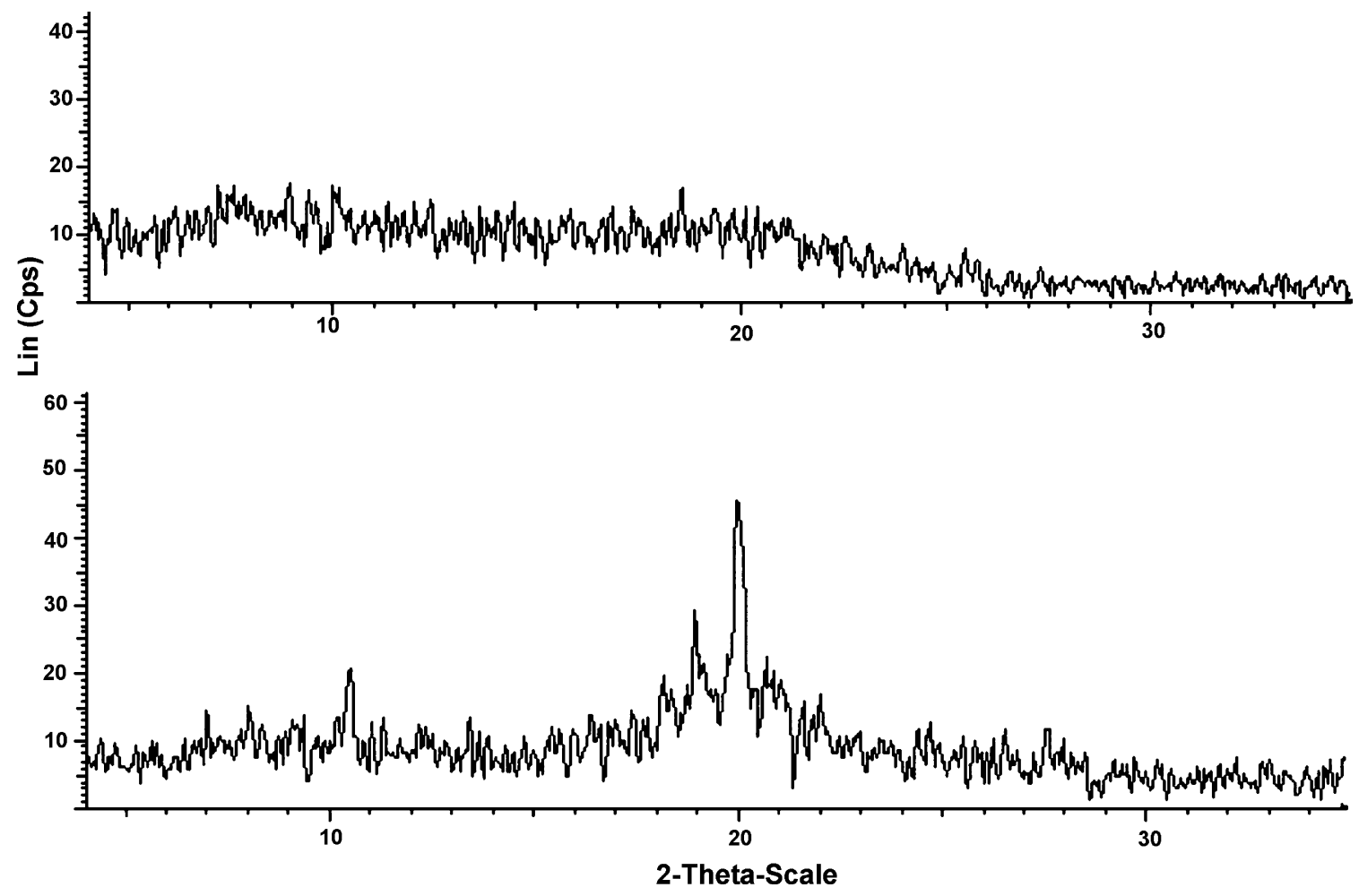

Fig. 9. XRD records of stored F1 (upper curve) and F5 (lower curve). 
The individual amorphous phase of lactose changed in crystallinity during long storage (stored in a hermetically closed container at room temperature for 12 months). It was explained by X-ray diffraction study (Fig. 9). Samples with two $T_{\mathrm{g}} \mathrm{s}$ exhibited characteristic peaks after the storage. In contrary the samples without $T_{\mathrm{g}}$ at around $110^{\circ} \mathrm{C}$ did not show alteration. It can be concluded that the separate amorphous phase was partially recrystallized during the long-term storage, which can induce stability problems of product.

\section{Conclusions}

Not only the particle size of the granules, but also the temperature of the powder mixture changed considerably during granulation at different operational parameters. The temperature increase was an indirect factor which can influence the dissolution of the powder mixture during granulation. At higher temperatures, a higher proportion of lactose and less HPMC are dissolved. The significant factors causing a temperature increase were the impeller speed and the dosing speed. Alteration of the batch size can induce a relevant change in the temperature increase.

The crystalline behaviour of lactose disappeared in films containing lactose and HPMC, as confirmed by DSC and XRD measurements. TMA indicated that an increase of the proportion of lactose in the film decreased the $T_{\mathrm{g}}$ of the film. This can be ascribed to the interaction of the components. At a lactose:HPMC ratio of $3: 5$, a second glass transition appeared. This points to the formation of a separate amorphous phase of lactose. Its crystallinity was changed during the storage.

Finally, it may be stated that evaluation of the temperature increase during granulation is necessary, since the small-scale granulation procedure can induce a dramatic change in this parameter. This should be borne in mind before prediction of the parameters applied for the granulation scale-up. Direct study of the composition of every individual binder bridge formed from soluble materials in the granules is impossible, but their indirect evaluation can be useful. These data provide additional information towards an understanding of granule formation in a small-scale high-shear granulator.

\section{Acknowledgements}

This work was supported by Hungarian Scientific Research Fund (OTKA) grant F-049310 and the DAAD/MÖB project (15/2007).

\section{References}

[1] S. Abdul, S.S. Poddar, J. Control. Release 97 (2004) 393-405.

[2] A.M. Hillary, A.W. Llojd, J. Swarbrick, Drug Delivery and Targeting for Pharmacists on Pharmaceutical Scientists, Taylor\&Francis, London, 2001.
[3] P. Sriamornsak, N. Thirawong, Y. Weerapol, J. Nunthanid, S. Sungthongjeen, Eur. J. Pharm. Biopharm. 67 (2007) 211-219.

[4] C.W. Vendruscolo, I.F. Andreazza, J.L.M.S. Ganter, C. Ferrero, T.M.B. Bresolin, Int. J. Pharm. 296 (2005) 1-11.

[5] I.J. Hardy, A. Windberg-Baarup, C. Neri, P.V. Byway, S.W. Booth, S. Fitzpatrick, Int. J. Pharm. 337 (2007) 246-253.

[6] A.P. Munasur, V. Pillay, D.J. Chetty, T. Govender, Int. J. Pharm. 323 (2006) 43-51.

[7] T.S. Owens, R.J. Dansereau, A. Sakr, Int. J. Pharm. 288 (2005) 109-122

[8] S.K. Singh, V. Naini, in: J. Swarbrick, J.C. Boylan (Eds.), Encyclopedia of Pharmaceutical Technology, vol. 1, second ed., Marcel Dekker Inc., New York, 2002.

[9] J. Herder, Å. Adolfsson, A. Larsson, Int. J. Pharm. 313 (2006) 57-65.

[10] Y. Zambito, A. Baggiani, V. Carelli, M.F. Serafini, G. Di Colo, J. Control. Release 102 (2005) 669-677.

[11] I. Özgüney, G. Ertan, T. Güneri, Il Farmaco 59 (2004) 549-555.

[12] M. Säkkinen, U. Seppälä, P. Heinänen, M. Marvola, Eur. J. Pharm. Biopharm. 54 (2002) 33-40.

[13] W. Pietsch, Agglomeration Processes, Wiley-VCH, Weinheim, 2002.

[14] L. Farber, G.I. Tardos, J.N. Michaels, Chem. Eng. Sci. 58 (2003) 4515-4525.

[15] D. Bika, G.I. Tardos, S. Panmai, L. Farber, J.N. Michaels, Powder Technol. 150 (2005) 104-116.

[16] P. Rajniak, C. Mancinelli, R.T. Chern, F. Stepanek, L. Farber, B.T. Hill, Int. J. Pharm. 334 (2007) 92-102.

[17] N. Blagden, M. de Matas, P.T. Gavan, P. York, Adv. Drug Deliver. Rev. 59 (2007) 617-630.

[18] D. Singhal, W. Curatolo, Adv. Drug Deliver. Rev. 56 (2004) 335-347.

[19] L.X. Yu, R.A. Lionberger, A.S. Raw, R. D’Costa, H. Wu, A.S. Hussain, Adv. Drug Deliver. Rev. 56 (2004) 349-369.

[20] R. Zelkó, Á. Orbán, K. Süvegh, J. Pharmaceut. Biomed. Anal. 40 (2006) 249-254.

[21] P.J. Sherrington, R. Olivier, Granulation, Heyden \& Son Ltd., London, 1981.

[22] D.M. Parikh, Handbook of Pharmaceutical Granulation Technology, Marcel Dekker Inc., New York, 1995.

[23] V.R. Sinha, R. Kumria, Int. J. Pharm. 249 (2002) 23-31

[24] K. Pintye-Hódi, P. Szabó-Révész, A. Keresztes, B. Selmeczi, Pharmazie 33 (1978) 735-737.

[25] K. Pintye-Hódi, G. Nagy, A. Keresztes, B. Selmeczi, G. Kedvessy, Pharmazie 35 (1980) 168-170.

[26] T. Kapsidou, I. Nikolakakis, S. Malamataris, Int. J. Pharm. 227 (2001) 97-112.

[27] F. Podczeck, Particle-Particle Adhesion in Pharmaceutical Powder Handling, Imperial College Press, London, 1998.

[28] E. Chevalier, M. Viana, C. Pouget, D. Chulia, Pharm. Dev. Technol. 12 (2007) 133-144.

[29] H. Vromans, H.G.M. Poels-Janssen, H. Egermann, Pharm. Dev. Technol. 4 (1999) 297-303.

[30] Á. Hegedüs, K. Pintye-Hódi, Chem. Eng. Process 46 (2007) 1012-1019.

[31] R.C. Rowe, Pharm. Sci. Technol. Today 3 (2000) 187-188.

[32] T.K. Bock, U. Kraas, Eur. J. Pharm. Biopharm. 52 (2001) 297-303.

[33] D. Ameye, E. Keleb, C. Vervaet, J.P. Remon, E. Adams, D.L. Massart, Eur. J. Pharm. Sci. 17 (2002) 247-251.

[34] E. Räsänen, O. Antikainen, J. Yliruusi, AAPS PharmSciTech. 4 (4) (2003) (article 53).

[35] J. Bajdik, G. Baki, A. Kelemen, K. Pintye-Hódi, Chem Eng. Res. Des. 86 (2008) $1-7$.

[36] R.C. Rowe, P.J. Sheskey, P.I. Weller, Handbook of Pharmaceutical Excipients, 4th ed., Pharmaceutical Press, London, 2003.

[37] Á. Gombás, P. Szabó-Révész, M. Kata, G. Regdon jr., I. Erős, J. Therm. Anal. Calorim. 68 (2002) 503-510.

[38] K. Mosén, K. Bäckström, K. Thalberg, T. Schaefer, A. Axelsson, H.G. Kristensen, Eur. J. Pharm. Biopharm. 64 (2006) 206-211.

[39] D.J. Burnett, F. Thielmann, J. Booth, Int. J. Pharm. 287 (2004) 123-133.

[40] J. Berggren, G. Frenning, G. Alderborn, Eur. J. Pharm. Sci. 22 (2004) 191-200.

[41] K.H. Bauer, K. Lehmann, H.P. Osterwald, G. Rothang, Coated Pharmaceutical Dosage Forms, Medpharm GmbH Scientific Publishers, Stuttgart, 1988.

[42] J. Berggren, G. Alderborn, Eur. J. Pharm. Sci. 21 (2004) 209-215. 
III 
Gyógyszerészet 52. 521-528. 2008.

\title{
Hüvelyben alkalmazott gyógyszerformák
}

\author{
Baki Gabriella és dr. Bajdik János
}

\section{Bevezetés}

A hüvelyben alkalmazott (intravaginális) gyógyszerformák elsősorban specifikus nőgyógyászati betegségek (föleg fertőzések) helyi kezelését teszik lehetővé, illetve fogamzásgátlásra használatosak [1]. Az utóbbi időben azonban egyre részletesebben tanulmányozták a hüvely abszorpciós kapacitását, mely következtében felmerült egy új szisztémás hatás kifejtésére alkalmas beviteli kapunak a lehetősége, ahonnan a gasztrointesztinális metabolizáció (first pass effect) kikerülésével közvetlenül a vérpályába jut a hatóanyag (a hidrofil hatóanyagok föleg paracellulárisan, a lipofil anyagok elsősorban transzcellulárisan). Ez különösen hasznos lehet azon hatóanyagok (pl. fehérjék, peptidhormonok) esetében, amelyek per os használatot követően könnyen metabolizálódnak [2-4]. Természetesen mindezek magukkal vonják új típusú gyógyszerformák megjelenését és a jelenlegi gyógyszerhordozók fejlesztését is. A fenti lehetőségek alapjai a VIII. Magyar Gyógyszerkönyvben (Ph. Hg. VIII.) található gyógyszerformákban is felfedezhetők [5], de egyes a piacon megjelent (és megjelenés előtt álló) készítmények ennek a csoportosítási rendszernek a határait feszegetik [6]. Jelen közleményben az egyes gyógyszerformák (elsősorban gyógyszerkönyvi csoportok) legfontosabb ismérveit, követelményeit és technológiai aspektusait kívánjuk bemutatni, részben a közforgalomban szereplő készítmények besorolásán keresztül.

A vaginális gyógyszerkészítmények előállításánál figyelembe kell venni, hogy a készítmény hatására a fiziológiás állapot a legkevésbé változzon meg, az alkalmazás könnyü legyen, a termék a megfelelő ideig maradjon a hatás szempontjából releváns helyen, a hatóanyag a kívánalmaknak megfelelően szabaduljon fel, illetve az egyszerre alkalmazott gyógyszerekkel kompatibilis legyen [2]. Ahhoz, hogy ezeknek meg tudjunk felelni, az alábbi anatómiai és élettani alapokat figyelembe kell venni.

\section{Anatómiai és élettani alapok}

A hüvely a külső szeméremtest és a méhnyak közötti 6-10 cm hosszú, elölről hátra összelapított, $2-3 \mathrm{~cm}$ széles, erősen redőzött, izmos falú, rugalmas, nagyon tágulékony csatorna $[7,8]$. Fala három rétegből épül fel: (1) a hámrétegből, mely többrétegü, el nem szarusodó laphám, (2) az izomrétegből, melyet simaizom és elasztikus rostok alkotnak és (3) a tunica adventitiaból, mely laza rostos kötőszöveti rétegböl épül fel.

A hüvelyfalban mirigyek nincsenek, azonban a nyálkahártyáját egy kevés váladék mindig nedvesen tartja. Ez a hüvelyi váladék részben a nyakcsatornából, részben levált hámsejtekből származik, valamint exszudációs eredetü [7]. Egészséges felnőtt nőkben a hüvelyi váladék pH-ja 4,0 és 5,0 között változik, ez függ a menstruációs ciklustól. A nemi érettség ideje alatt a hámsejtek glikogénben gazdagok. A hám felszíni rétege leválik, citolízis folyamán szabaddá válik a glikogén, amit a hüvelyben megtalálható Lactobacillus-flóra (ún. Döberlein-bacillus) tejsavvá alakít. Egyrészt így, másrészt szénhidrátokból keletkező tejsav hatására jön létre a savanyú kémhatás, amely jelentős védelmet nyújt a fertőzések ellen. A savasság klinikailag jelentős szerepet játszik a patogén baktériumok szaporodásának megelőzésében, és összefüggés mutatható ki a hüvelyi váladék $\mathrm{pH}-\mathrm{ja}$, valamint a Chlamydia okozta fertőzések gátlása között [9]. A glikogéntartalom hormonális hatásokra változhat, pl. terhesség alatt növekszik (így ez idő alatt alacsonyabb a pH, kb. 3,8-4,4), menopauza után csökken. A nyakcsatornából származó nyák kémhatása 6,5 és 9 közötti, ennek összetétele és fizikai jellemzői változnak a menstruációs ciklussal. Egészséges nőkben naponta 1-3 g nyák termelődik, azonban az ovuláció ideje alatt nagyobb mennyiség is termelődhet naponta és ekkor a kevésbé viszkózus váladék elősegíti a hímivarsejtek bejutását a méhbe.

A hüvelyi gyógyszerbevitel szempontjából fontos szerepe van az ott található enzimeknek (foszfatáz, észterázok, glukoronidáz stb.) és mikroorganizmusoknak is. A Lactobacillus különböző típusai mellett egyéb mikroorganizmusok is találhatók normál fiziológiás körülmények között a vagina nyálkahártyáján, például Streptococcus, Corynebacterium, Escherichia, Mycobacterium [10]. Ezek a normál savas közegben nem jelentenek zavaró tényezőt, de az intravaginális gyógyszer stabilitására befolyással lehetnek. Amenynyiben ezt az egyensúlyt különféle behatások (pl. infekció, fizikai behatás, hüvelyi öblítők használata, hormonháztartás változása) megzavarják, a mikrobiológiai flóra is megváltozhat. A pH-érték növekedése a nemkívánatos mikroflóra szaporodásához vezethet, de elöfordulhat az is, hogy az említett okok következtében először a nemkívánatos mikroflóra nő, ami azután csökkenti a savasságot. 


\section{Kórélettani alapok}

A bevezetésben említésre került, hogy a vaginális beviteli mód jelenleg elsősorban a helyi kórképek kezelésére szolgál. Ezek megjelenési formái döntő hatással lehetnek a választandó gyógyszerformára. A hüvely mikroorganizmusok által okozott gyulladása gyakori nőgyógyászati kórkép. Lehet bakteriális, gombás eredetű vagy trichomonas okozta fertőzés. A vulvitist rendszerint Candida fertőzés okozza, ami helyileg Candida elleni hatóanyagot tartalmazó krémmel lokálisan jól kezelhetö. Rendszerint azonban hüvelyi infekció is jelen van, amit természetesen szintén kezelni kell. Ez történhet szintén lokálisan kúp, kenőcsök, krémek alkalmazásával, de szükség lehet szisztémás antimikotikus kezelés folytatására is. A hüvely normális (savas) pH-jának helyreállítását időnként tejsavat tartalmazó készítményekkel kísérlik meg. A hüvelyi irrigálással kapcsolatban, az utóbbi években egyre több szakmai kifogás merült fel. Az öblítés egyrészt elősegítheti a fertőzések felfelé való terjeszkedését (akár a hasüregbe is), másrészt a normál hüvelyi flóra kimosásával maga is hozzájárul a kóros állapot fenntartásához [11].

A vaginitis a hüvely gyulladásos megbetegedését jelenti. Ez a betegség gyakori nőgyógyászati probléma, a nőket bármely életkorban érintheti. Baktériumok, vírusok, gombák, kémiai anyagok (krémekben, dezodorokban!) vagy a ruházat irritáló hatása is okozhat vaginitist. Sok esetben ez a kórkép szexuális úton terjedő betegségek következménye. A hüvely normál baktériumflóráját számos tényező befolyásolja, az ezekben fellépő zavarok gyakran torkollnak vaginitisbe.

A vaginális fluor irritációval és váladékképződéssel járó fertőzés. A normál flóra megváltozása (pl. progeszteron túlsúly, antibiotikum alkalmazása, terhesség, rosszul kezelt cukorbetegség) ahhoz vezet, hogy a hüvely pH-ja megemelkedik, ez pedig a Candida albicans elszaporodását eredményezi. Jellegzetes tünetei a vaskos, fehér színű, nyálkás-vizes folyás, amely rendszerint szagtalan, illetve a vulva kipirosodása és duzzanata.

A bakteriális vaginosis/colpitis esetében a normál hüvelyflóra egyensúlya valamely baktérium túlszaporodása irányába billen el, a gyulladást ez okozza. Leggyakoribb kórokozói: Gardnella vaginalis, Mobiluncus, Bacteroides, Mycoplasma.

A trichomoniasis szexuális úton terjedő fertőző betegség. Okozója a Trichomonas vaginalis, melyet közösülés során a szexuális partnerek adnak át egymásnak, a fertőzés gyakran tünetmentes. Jellegzetes klinikai tünete a bőséges váladék ürülése a gyulladt hüvelyből. Ehhez társul a külső nemi szerv területén égő érzés és viszketés, valamint fájdalmas vizeletürítés.
A chlamydia vaginitis a leggyakrabban előforduló szexuális úton terjedő betegség, amely sajnos sokszor olyannyira tünetmentesen zajlik, hogy diagnosztizálatlan marad. A fel nem ismert és ezért kezeletlen chlamydia fertőzés késői szövődményeként kismedencei gyulladásos betegség alakulhat ki, amely meddőséget, krónikus alhasi fájdalmakat és méhen kívüli terhességet eredményezhet. A leggyakoribb tünetek a következők lehetnek: nagyobb mennyiségü hüvelyváladékozás, enyhe vérzés, föleg közösülés után, vizelés alatti égö érzés, genny megjelenése a vizeletben, a vulva és a húgycsőnyílás kipirosodása és duzzanata.

Vírusok gyakran okoznak vaginitist, a fertőződés általában szexuális közösülés útján történik. Leggyakrabban a Herpes simplex vírus okoz vaginitist (herpes simplex genitalis), ennek legföbb tünete a vulva fájdalmas kirepedezése és felhólyagosodása. Másik jellemző vírus a Humán papillomavirus (HPV), amely szintén szexuális úton terjed. Főbb tünete a vulva, a végbél és a hüvelybemenet környékén megjelenő szemölcsök. Ezek azonban nem minden esetben alakulnak ki, ilyenkor a vírus jelenléte hüvelykenet vizsgálattal igazolható.

A természetes öregedési folyamat (menopauza) következtében jelentős változások figyelhetők meg a női szervezetben. A hüvely mérete, elaszticitása, erezettsége csökken, a nyálkahártya elvékonyodik. A glikogén mennyisége rendkívül lecsökken vagy teljesen hiányzik is, ennek következtében megváltozik a hüvelyi mikroflóra és a kémhatás is. A hüvelyi szekréció lecsökken és a váladék hígabb lesz, a $\mathrm{pH}$ viszont megnő 4,0-5,0-ről 7,0-7,4-re. A bakteriális és gombás fertőzések elleni rezisztencia a savas baktériumok számának csökkenése miatt lecsökken [12].

A hüvelyben alkalmazott készítmények szolgálhatnak a daganatos betegségek helyi kezelésére is. A hüvelyrák világszerte a legritkábban előforduló genitális tumor. Véres folyás, kontaktvérzés, székeléskor keletkező hüvelyi vérzés az első jelek. Gyakran a méhnyakrák áttéteként alakul ki (szintén jelentős váladékképződés kísérheti).

A hüvelyi készítményeket használhatjuk még az alsó urogenitális traktus ösztrogénhiánnyal összefüggő atrófiájának kezelésére, melyre legalkalmasabb gyógyszerforma a hüvelykrém.

Látható, hogy a helyi problémák vezető tünete a megnövekedett mennyiségü hüvelyi folyadék, mely az egyes gyógyszerformák alkalmazhatóságát is befolyásolhatja (krémek kimosódása, tabletták eltérő szétesése stb.). Szintén sokszor figyelhető meg az égő érzés, fájdalom, mely bizonyos gyógyszerformák (pl. tabletták) alkalmazását megnehezíti vagy kényelmetlenné teszi. Következésképpen a beteg együttmüködésének megnyeréséhez ezek a szempontok a formulálás során mindenképpen követendőek. 


\section{Hivatalos gyógyszerformák}

Az alábbi összeállításban a jelenleg hivatalos VIII. Magyar Gyógyszerkönyv csoportosítási elveit kívánjuk bemutatni. A magisztrális gyógyszerkészítés során alkalmazandó jelenleg hivatalos Szabványos Vényminták (FoNo VII.) is tartalmaznak különböző vaginális készítményeket, de mivel ez a gyüjtemény még a Ph. Hg. VII. alapjain nyugszik, szükségesnek véltük röviden ezen formák megemlítését is, de a részleteket a $\mathrm{Ph}$. Hg. VIII. szerinti csoportosításnál tüntetjük fel.

\section{Ph. Hg. VII.}

$\mathrm{Az}$ egyértelműen hüvelyben való alkalmazhatóság csak a végbélkúpokkal egy csoportban tárgyalt hüvelykúpok, hüvelygolyók és hüvelyhengerek esetén érhető tetten. A többi gyógyszerforma-csoportnál (pl. oldatok, kenőcsök, emulziók) a hüvelyi alkalmazásra vonatkozó specialitások nem kerültek feltüntetésre, csak a tabletta vizsgálatok között szerepel rövid utalás a vaginális készítmények dezintegrációs és kioldódási vizsgálatához használandó vizsgáló folyadék összetételére.

A hüvelykúpok, -golyók és -hengerek a testüregekben alkalmazott, a test hőmérsékletén megolvadó vagy a testnedvekben feloldódó gyógyszerkészítmények. Ezek a hatóanyagot emulziós, szuszpenziós vagy oldott formában tartalmazzák.

A hüvelykúpok alakja hengeres, a végbélkúpokhoz hasonló, vagy pedig lapított, mandula alakú, tömegük $2,0-3,0 \mathrm{~g}$. A hüvelygolyók tömege $1,0-4,1 \mathrm{~g}$, a hüvelyhengereké pedig $6-10 \mathrm{~g}$.

\section{FoNo VII.}

A FoNo VII. szintén csak a hüvelygolyót és a hüvelyhengert (globulus, ovulum) említi, amelyet a testüregben testhőmérsékleten megolvadó, vagy a testnedvekben feloldódó gyógyszerkészítményként definiál és szintén a végbélkúpokkal egy csoportban tárgyalja. A gyüjteményben 5 hüvelyben alkalmazandó készítmény hivatalos.

\section{Ph. Hg. VIII.}

A hüvelyi beviteli kapun alkalmazott készítményeket a $\mathrm{Ph}$. Hg VIII. a Hüvelyben alkalmazott (vaginális) gyógyszerkészitmények - Vaginalia csoportba sorolja. A hüvelyben alkalmazott (vaginális) gyógyszerkészitmények rendszerint helyi hatás elérésére szánt, folyékony, félszilárd vagy szilárd készitmények. Megfelelö vivöanyagban/készitményalapban egy vagy több hatóanyagot tartalmaznak. A hüvelyben alkalmazott gyógyszerkészítményeket a Gyógyszerkönyv szerint az alábbi gyógyszerformákba sorolhatjuk:

- hüvelykúpok,

- hüvelytabletták,

- hüvelykapszulák,

- hüvelyoldatok, -emulziók és -szuszpenziók,

- tabletták hüvelyoldatokhoz, ill. szuszpenziókhoz,

- félszilárd vaginális gyógyszerkészítmények,

- hüvelyhabok,

- gyógyszeres hüvelytamponok.

A gyógyszerkönyv alapján a vaginális gyógyszerkészítmények gyártása, csomagolása, tárolása és forgalmazása folyamán biztosítani kell a helyi használatra szánt készítményekre előírt mikrobiológiai tisztaságot. Eszerint a készítmény grammonként $10^{2}$ aerob mikroorganizmust (gomba és baktérium), $10^{1}$ enterobaktériumot és bizonyos Gram negatív baktériumokat tartalmazhat, ill. nem lehet jelen Pseudomonas aeruginosa és Staphylococcus aureus.

Ezen készítmények vizsgálatánál általánosan az adagolási egységek, a hatóanyag-tartalom és a tömeg egységességét, továbbá a kioldódás-vizsgálatokat kell előírás szerint elvégezni. Egyes gyógyszerformáknál egyéb speciális vizsgálatok is szükségesek.

\section{A Ph. Hg. VIII.-ban hivatalos gyógyszerformák}

\section{Hüvelykúpok}

A hüvelykúpok szilárd, egyadagos gyógyszerkészitmények. Formájuk sokféle, rendszerint tojás alakúak, méretük és állományuk révén alkalmasak a hüvelybe juttatásra. A kúpok megfelelö alapban (kúpmasszában) oldott vagy diszpergált hatóanyago (ka)t tartalmaznak. A kúpmassza vízben oldható, ill. diszpergálható vagy testhömérsékleten megolvad. A készitmények szükség esetén segédanyagokat - pl. töltöanyagokat, adszorbenseket, felületaktiv anyagokat, mikrobiológiai tartósitószereket, valamint az illetékes hatóság által engedélyezett szinezéket - tartalmazhatnak.

A hüvelykúpokat általában öntéssel állitják elö. A kúpok elöállitása során esetenként biztositani kell, hogy a hatóanyag(ok) részecskemérete megfelelö és ellenörzött legyen. A hatóanyago(ka)t szükség esetén elözetesen poritják, és megfelelö szitán átszitálják.

Az öntéssel készülö kúpok esetében a hatóanyagot is tartalmazó kúpmasszát melegitéssel megfelelöen felolvasztva, alkalmas formába öntik. A kúpok lehülés közben szilárdulnak meg. Az elöállitáshoz különbözö vivöanyagokat alkalmaznak, így pl. szilárd zsirt, makrogolokat, kakaóvajat és különbözö gélszerü keverékeket (amelyek pl. zselatinból, vizböl és glicerinböl állnak).

A nyújtott helyi hatású hüvelykúpok esetében a megfelelö hatóanyagleadást alkalmas vizsgálattal igazolni kell. 
Ezen gyógyszerformáknál a szétesési vizsgálatokat is el kell végezni. Ezek során a hüvelykúpok állapotát (indokolt esetek kivételével) 60 perc elteltével vizsgáljuk.

Ahogy az a gyógyszerkönyvi elöírásban szerepel, a hüvelykúpokat mind magisztrális, mind ipari méretben elsősorban öntéssel állíthatjuk elő. A formáláshoz számos segédanyag alkalmazása indokolt, de a kúpalapok minden esetben felhasználásra kerülnek. A FoNo VII.-ben hivatalos és a magisztrális gyógyszerkészítés során alkalmazható készítményalapok a szilárd zsír (Adeps solidus 50), a tenzideket tartalmazó szilárd zsír (Adeps solidus compositus) és makrogol elegy (Massa macrogoli), valamint használható még a FoNo VI.-ban hivatalos kakaóvaj (Butyrum cacao). Az ipari gyógyszerkészítményekben is a legnépszerűbb alapok a szilárd zsír különböző típusai (telítetlen és főleg telített zsírsavak mono-, di- és trigliceridjeinek különböző arányú keverékei). A hidrofil, higroszkópos tulajdonságú makrogolok (a makrogol 1000-6000 különböző arányokban) is jelentős szerepet játszanak. Ezek a készítmények a testnedvekben feloldódnak, tehát megfelelő mennyiségű hüvelynedv szükséges a hatás kialakulásához. Ennek hiányában a nyálkahártya irritáló hatása kellemetlen lehet. A zselatinból, vízből és glicerinből álló hidrofil rendszereknél ez a nem kívánt hatás kevésbé léphet fel és a lágyabb konzisztenciával együttesen kényelmesebb alkalmazást tesznek lehetővé.

Az alábbi segédanyagok szintén alkalmazhatók a formulálás során:

- Töltőanyagok: laktóz, mannit, szorbit.

- Viszkozitást növelő anyagok: hidrofil kolloid szilícium-dioxid, gliceril-monosztearát, polimerek (pl. hidroxi-propilcellulóz).

- Konzisztencia lágyítók: semleges olaj.

- Dezintegrálószerek: nátrium-hidrogénkarbonát és savak (adipinsav, borkősav) együttesen.

- Diszpergálószerek pl. poliszorbátok, szorbitán-trioleát.

- Olvadási, ill. dermedési hőmérsékletet növelő anyagok: fehérviasz, cetil-sztearil-alkohol, cetáceum, cetil-alkohol.

- Folyadékmegkötő anyagok: hidrofil kolloid szilícium-dioxid.

A FoNo VII. elöírása alapján a kúpok színezése nem megengedett, ezzel szemben a gyógyszerkönyv elöírásai alapján ezeknek a segédanyagoknak az alkalmazása lehetséges. A magisztrális gyógyszerkészítés során a massza beragadásának megakadályozására szükség esetén az öntőformákat folyékony paraffinnal bekenjük, vagy bepermetezzük. Az ipari gyártás során az öntés leginkább a gyógyszerkönyv alapján alkalmazható, megfelelö formára kialakított csomagolóanyagokba direkt módon történik, vagyis az „öntőformá- ból" csak a felhasználó fogja a terméket eltávolítani, de természetesen ennek is könnyen meg kell történnie.

Gyári készitmények:

- Pimafucin hüvelykúp,

- Klion hüvelykúp,

- Canifug hüvelykúp,

- Canifug Komb hüvelykúp,

- Gyno-Pevaryl hüvelykúp,

- Pevaryl $G$ hüvelykúp,

- Mikogal hüvelykúp,

- Betadine hüvelykúp,

- Patentex oval hüvelykúp,

- Pharmatex hüvelykúp,

- Ortho-gynest $\mathrm{D}$ hüvelykúp,

- Ovestin hüvelykúp.

\section{Hüvelytabletták}

A hüvelytabletták szilárd, egyadagos gyógyszerkészitmények. Rendszerint megfelelnek a Ph. Hg. VIII. Tabletták c. cikkelyben a bevonat nélküli vagy a filmbevonatú tablettákra megadott definícióknak. A nyújtott helyi hatású hüvelytabletták esetében a megfelelö hatóanyagleadást alkalmas vizsgálattal igazolni kell.

A hüvelytabletták szétesés-vizsgálatát a hüvelykúpokra kifejlesztett módszer segítségével végezzük és a tabletták állapotát (indokolt esetek kivételével) 30 perc elteltével vizsgáljuk. A Gyógyszerkönyv a tabletták (tablettae) esetén a hatóanyag-kioldódás vizsgálatát is elöírja, de a cikkely bevezetésében szerepel, hogy a követelményeket nem kell feltétlenül alkalmazni a vaginális készítményekre.

A tabletták előállítása során a technológia megválasztásakor figyelembe kell venni, hogy ezek a termékek még kis hatóanyagtartalom mellett is nagy térfogatúak (pl. Klion D hüvelytabletta $200 \mathrm{mg}$ hatóanyagtartalom mellett $24 \mathrm{~mm}$ hosszú és $14 \mathrm{~mm}$ magas). Ez a tulajdonság az alkalmazást könnyíti meg, melyhez az is hozzájárul, hogy a készítmények rendszerint lapítottak, mandula vagy oblong alakúak, esetleg az egyik oldalukon lekerekítettek.

A nagy tömeg biztosításához szükséges segédanyagok közül kiemelkedik a laktóz alkalmazása, mivel ez a hüvelyi Lactobacillusok természetes szubsztrátja, vagyis hozzájárul az egészséges mikroflóra kialakításához és ennek következtében a természetes hüvelyi védelemhez [13]. Szintén ennek a fenntartásához járul hozzá a kalcium-laktát alkalmazása töltőanyagként. Egyes készítményekben a tejsav (hidrofil kolloid szilícium dioxiddal együtt) tölti be ezt a szerepet.

A segédanyagok megválasztásakor figyelembe kell venni, hogy a készítmények szétesését biztosító folyadék mennyisége lényegesen kevesebb, mint a per os tablettáknál. Ezért ebben az esetben a nagyhatékony- 
ságú dezintegránsokra (föleg módosított keményítők, kroszpovidon) van szükség. Ilyen hatás érhető el a szén-dioxid termelésen keresztül is, melyet savak (főleg adipinsav és borkősav) és nátrium-hidrogénkarbonát együttes alkalmazásával segíthetjük elő. Ezek a rendszerek igen népszerüek, de meg kell említeni, hogy a nedvességre érzékenyek, vagyis a nedves granulálás nem megfelelő módszer a köztitermékek formulálásához. A nagytömegủ tabletták előállítása direkt préseléssel egy igen nagy kihívás a formuláció során. Az ehhez szükséges hatékony száraz kötöanyagok (pl. kopolividon) és esetleg hidrofil csúsztatóanyagok (pl. makrogolok) is megtalálhatók számos öszszetételben.

A definíció alapján a készítmények lehetnek bevontak is. A bevonás a hatóanyag védelmén kívül az alkalmazást is segítheti. Ilyen filmbevonat kialakítását elsősorban a vízben jól oldódó cellulóz-éterek (pl. hidroxi-propil-metilcellulóz) alkalmazásával érhetjük el.

Gyári készitmények:

- Candibene hüvelytabletta,

- Canesten hüvelytabletta,

- Canesten Kombi hüvelytabletta,

- Clotrimazol AL hüvelytabletta,

- Klion-D hüvelytabletta,

- Gynoflor hüvelytabletta,

- Pharmatex hüvelytabletta,

- Vagifem hüvelytabletta.

\section{Hüvelykapszulák}

A hüvelykapszulák szilárd, egyadagos gyógyszerkészitmények. Általában a lágy kapszulákhoz hasonlóak, csak formájuk és méretük különbözö. A hüvelykapszulák formája sokféle lehet, általában tojás alakúak. Felszinük sima és egyenletes. A nyújtott helyi hatású hüvelykapszulák esetében a megfelelö hatóanyagleadást alkalmas vizsgálattal igazolni kell.

A hüvelytabletták szétesését a hüvelykúpokra kifejlesztett módszer segítségével végezzük és a kapszulák állapotát (indokolt esetek kivételével) 30 perc elteltével vizsgáljuk.

Ezen gyógyszerformák nagy előnye a tablettákhoz viszonyítva, hogy a hatóanyagok nemcsak szilárd formában dolgozhatók fel, hanem nagyobb mennyiségben folyékony vagy félszilárd formában is. A formulálás során a kényelmes alkalmazhatóságot szintén szem elött kell tartani, ezért elsősorban a lágy zselatinkapszulák jöhetnek számításba. A kapszulafalat alkotó komponensek arányának megváltoztatásával azonos anyagokból lágy, illetve kemény zselatinkapszula egyaránt kialakítható. A lágy kapszulában nagyobb a víz és a folyadékmegkötő segédanyagok (szorbit, glicerin) aránya [14].
Gyári készitmény:

- Utrogestan hüvelykapszula.

Hüvelyoldatok, -emulziók és -szuszpenziók

A hüvelyoldatok, -emulziók és -szuszpenziók helyi hatás elérésére, öblitésre, esetleg a hüvelybe juttatva diagnosztikai céllal alkalmazott, folyékony gyógyszerkészitmények. Tartalmazhatnak segédanyagokat is, pl. a viszkozitás beállitása, a pH beállitása, ill. stabilizálása, a hatóanyag(ok) oldhatóságának növelése, valamint a készitmény stabilizálása céljából. A segédanyagok nem befolyásolhatják kedvezötlenül a kivánt gyógyhatást, és az alkalmazott töménységben nem válthatnak ki túlzott helyi irritációt.

A hüvelyemulziók szétválhatnak ugyan, de rázogatásra könnyen újra kell képzödniük. A hüvelyszuszpenziókban elöfordulhat üledék, ennek azonban rázogatás hatására könnyen diszpergálódnia kell, és az újraképzödött szuszpenziónak elég stabilnak kell maradnia ahhoz, hogy az egynemü készitmény bevihetö legyen.

A hüvelyoldatokat, -emulziókat és -szuszpenziókat egyadagos tartályokban forgalmazzák. A tartályok kiképzése többnyire alkalmas a készítmény hüvelybe juttatására, vagy ha mégsem, akkor a készítményhez megfelelö szereléket mellékelnek.

A hüvelyszuszpenziók előállítása során biztosítani kell, hogy a részecskeméret az alkalmazási módnak megfelelő és ellenőrzött legyen.

Ahogy a bevezetőben említésre került, ezen készítmények hatékonyságáról megoszlanak a vélemények. A kis mennyiségü folyadékban formulált hatóanyagokkal kiküszöbölhető a hüvelyi védőflóra eltávolítása, bár itt mindig szem elött kell tartani, hogy nagyobb koncentrációban alkalmazva egyes hatóanyagok (és segédanyagok) igen jelentős nyálkahártya-irritációt okozhatnak. A hatékonyság növelhető és ezzel párhuzamosan a kimosódás veszélye csökkenthető a viszkozitásnövelő segédanyagok (pl. cellulózéterek, alginátok) alkalmazásával.

Gyári készitmény:

- Vagothyl oldat.

Tabletták hüvelyoldatokhoz és -szuszpenziókhoz

A hüvelyoldatok és -szuszpenziók készitésére szánt tabletták közvetlenül a felhasználás elött vízben oldandó, ill. diszpergálandó, egyadagos gyógyszerkészitmények. Tartalmazhatnak olyan segédanyagokat is, amelyek elösegítik az oldódást vagy diszpergálódást, illetve megakadályozzák a tömör üledék képzödését. Oldás, ill. diszpergálás után meg kell felelniük a hüvelyoldatokra, ill. -szuszpenziókra vonatkozó követelményeknek. 
A tablettáknak és kapszuláknak $15-25{ }^{\circ} \mathrm{C}$-on a tabletták és kapszulák szétesés-vizsgálati elöírása szerint 3 percen belül szét kell esniük.

Az előállítás során a gyors oldódást vagy diszpergálódást kell szem előtt tartani. Ezt legkönnyebben a pezsgőtablettáknál alkalmazott savas komponens (adipinsav, borkősav) és nátrium-hidrogénkarbonát együttes alkalmazásával érhetjük el.

Gyári készitmény:

- Colpo-cleaner Jód pezsgőtabletta hüvelyöblítő oldat készítéséhez.

Félszilárd vaginális gyógyszerkészitmények

A félszilárd vaginális gyógyszerkészitmények kenöcsök, krémek vagy gélek lehetnek. A készitmények többnyire egyadagos tartályokban, a használatukhoz alkalmas eszközzel kerülnek forgalomba. A félszilárd vaginális készítményeknek meg kell felelniük a Ph. Hg. VIII. Börfelületre szánt (dermális), félszilárd gyógyszerkészítmények c. cikkelyben elöirt követelményeknek.

A készítmény kifejlesztése során igazolni kell, hogy az egyadagos tartályban kiszerelt készítmény a tartályból a névleges tartalmának megfelelő mennyiségben kivehetö.

A készítményeknél alapvető szempont a könnyü alkalmazhatóság. Ezért kedveltek a lágy konzisztenciájú, hatóanyagot oldott állapotban tartalmazó o/v krémek. A segédanyagok közül érdemes megemlíteni a széles körben alkalmazott propilénglikolt, mivel ez a nyálkahártya-izgató hatást nem mutató komponens részben a hatóanyag oldékonyságát képes növelni, részben a nedvességmegkötő hatásán keresztül a kenőcsök beszáradását akadályozza meg. A krémek lipofil komponenseként föleg ásványi eredetü komponensek kerülnek felhasználásra, vázképzőként pedig a különböző zsíralkoholok (cetil-alkohol) és zsírsav-észterek (cetilpalmitát). Emulgensként elsősorban a szorbitán származékok (poliszorbátok) használatosak, bár ezek közül is egyre népszerübbek a kevésbé irritatív polioxetilénlánc-mentes komponensek (szorbitán-sztearát). Mikrobiológiai tartósítószerek alkalmazása az o/v típusú rendszereknél mindenképpen indokolt és döntően a benzil-alkohol kerül felhasználásra. Bizonyos készítményekben segédanyagként megtalálható a tejsav is, mely a hüvelyi $\mathrm{pH}$ beállítása miatt akár hatóanyagként is értelmezhető.

A félszilárd intravaginális készítmények között is egyre népszerübbek a biológiai membránokhoz és az ezt borító nyákréteghez való kapcsolatot biztosító ún. bioadhezív, illetve mukoadhezív anyagokat tartalmazó gyógyszerkészítmények [15-17]. A komponens(ek) ezen tulajdonsága lehetővé teszi, hogy a készítmény tartósan az alkalmazás helyén maradjon és még szabályozott hatóanyag-felszabadulást is képes biztosítani. Ilyen komponensek egyes cellulóz-éterek (hidroxipropil-metilcellulóz), akrilsav-származékok (pl. karbomer) és egyéb természetes eredetü komponensek (pl. alginátok). Ezek a segédanyagok a szilárd gyógyszerformáknál és a speciális modern gyógyszerformáknál is alkalmazásra kerülnek [18, 19].

Gyári készítmények:

- Dalacin hüvelykrém,

- Canesten Kombi krém,

- Canifug Komb krém,

- Gynazol 2\% hüvelykrém,

- Batrafen hüvelykrém,

- Pharmatex hüvelykrém, egyadagos hüvelykrém,

- Linoladiol $N$ hüvelykrém,

- Estrokad hüvelykrém,

- Ovestin krém.

Hüvelyhabok

A hüvelyhaboknak meg kell felelniük a Ph. Hg. VIII. Gyógyszeres habok (Musci medicati) c. cikkelyben elöirt követelményeknek. A gyógyszeres hab nagytérfogatú gáz folyadékban való diszpergálásával képzödik. A készítmény általában egy vagy több hatóanyagot, habképzödést elösegitö felületaktiv anyagot és egyéb segédanyago (ka)t tartalmaz. A gyógyszeres hab általában a kezelés pillanatában képzödik, mégpedig túlnyomásos tartályba töltött, folyékony készítményböl. A tartály a hab kifúvatására alkalmas, szelepes, nyomógombos feltéttel van ellátva.

A Gyógyszerkönyv alapján vizsgálni kell a hab relatív sürüségét, a tágulási időt és szükség esetén (nyílt sebek kezelésére szánt készítményeknél) a sterilitást.

A folyadékokkal szembeni előnye, hogy nagyobb felületen egyenletesebben oszlatható el és a retenciós idő is hosszabb. Termodinamikailag nem stabilak, idövel a szerkezet letörik, a buborékok eltávoznak. Jellemzően felületaktív anyagokat (poliszorbátok) tartalmazó folyadékokból alakítjuk ki túlnyomásos gáz (n-bután, i-bután) segítségével. A habokat előszeretettel alkalmazzák az állatgyógyászati vaginális készítményeknél is.

\section{Gyógyszeres hüvelytamponok}

A gyógyszeres hüvelytamponok szilárd, egyadagos gyógyszerkészitmények, amelyeket meghatározott idötartamra kell a hüvelybe helyezni. A készitményeknek meg kell felelniük a Ph. Hg. VIII. Gyógyszeres tamponok (Tamponae medicatae) c. cikkelyben elöírt követelményeknek. A gyógyszeres tamponok meghatározott idötartamra valamely testüregbe helyezendö, 
szilárd, egyadagos gyógyszerkészitmények. A hordozóanyagot - pl. cellulózt, kollagént vagy szilikont - egy vagy több hatóanyaggal impregnálják.

Az impregáláshoz használt folyékony vagy félszilárd készítmény segédanyagait találjuk meg a rendszerben. Vagyis lehetnek a termékben viszkozitásnövelö, a $\mathrm{pH}$ beállításhoz használt savas komponensek vagy diszpergálószerek.

Gyári készítmény:

- Pharmatex hüvelytampon.

\section{Modern gyógyszerformák}

Az alábbi gyógyszerformák a gyógyszerkönyvi csoportosítási elvek alapján nem sorolhatók be. Ezek a gyógyszerformák részben megjelentek a közforgalomban, részben pedig fejlesztési stádiumban vannak, tehát a közeljövőben a gyakorlatban is várható az alkalmazásuk.

Napjainkban egyre inkább előtérbe kerülnek a tartós hatású készítmények, amelyek több előnnyel is rendelkeznek a hagyományos gyógyszerkészítményekkel szemben: ezek a készítmények a szervezetben hosszú ideig raktárt képezhetnek, melyből folyamatosan szabadul(nak) fel hatóanyag(ok), és így állandó és egyenletes vérszintet biztosítnak, azaz, ezekben a rendszerekben a hatóanyag-koncentráció kevésbé ingadozik a minimális és maximális értékek között. Emellett jobb a hatóanyag biohasznosíthatósága, amely lehetővé teszi, hogy kisebb mennyiségü hatóanyagot alkalmazzunk. Ez a technológiai megoldás gyakran lehetővé teszi a gyógyszerformának a hatás helyén szabályozott ideig való tartózkodását is és ezzel párhuzamosan a hatóanyag helyi felszívódását. Nem utolsósorban, a nyújtott hatóanyagleadás következtében az előállított készítményt ritkábban elegendő alkalmazni [20, 21]. Ezeknél a formáknál még nagyobb a jelentősége a kényelmes alkalmazhatóságnak, továbbá jogos igény, hogy ne zavarják a szexuális életet, valamint eltávolíthatóak legyen a hatás megszüntetése céljából.

A hüvelygyürük elöre meghatározott, szabályozott sebességgel szabadítják fel a hatóanyagot a szisztémás keringésbe. A hüvelygyürük általában rugalmas biokompatibilis szilikon elasztomerekből vagy etilén-vinilacetátból készülnek, egy hatóanyag nélküli belső gyürüből és egy hatóanyagtartalmú bevonatból állnak (1. ábra). Ezeket a gyógyszerkészítményeket a méhnyakig helyezik fel, elsősorban fogamzásgátlás céljából. A rendszer 21 napig marad a hüvelyben, majd 7 napra eltávolítják, melyet megvonásos vérzés követ. $\mathrm{Az}$ újabb generációs készítmények (ún. szendvicstípus) hatóanyagtartalmú szilikon polimer mátrix belsőt és ezen egy hatóanyag nélküli szilikon polimer membránt tartalmaznak. Ez a technológia csökkenti az első ciklusban a túlzottan gyors hatóanyag-felszabadulást, de elszakadás esetén a hatás módosulásával kell számolni [2].

Gyári készitmény:

- Nuvaring hüvelygyürü.

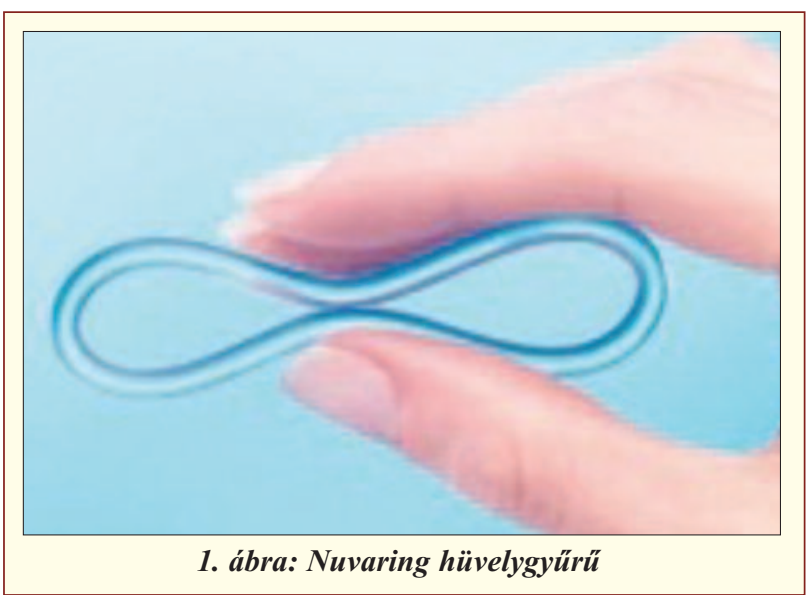

Az orális fogamzásgátlók biztonságos alkalmazásának feltétele a napi rendszeres hormonbevitel biztosítása, mely a használó maximális együttmüködésének eredményeként biztosítható. Ezért jelent nagy előnyt az olyan terápiás rendszerek megjelenése, melyek a folyamatos hatóanyag-bejuttatást a napi kívánt mértéknek megfelelöen több éven át biztosítani képesek. Az intrauterin rendszer „T” alakú felépítése bizonyult a legelőnyösebbnek (2. ábra). Az alapanyaga lehet EVA (etilén-vinil-acetát) kopolimer vagy különböző sziloxán elasztomer. Az üreges szárban elhelyezhető a hormonraktár, mely szilikonolajban diszpergálva vagy egy polidimetilsziloxános keverékben tartalmazza az általában mikronizált farmakont. A szervezet hormonterhelése elenyésző a konvencionális, orális alkalmazáshoz képest (pl. a Mirena intrauterin rendszer $52 \mathrm{mg}$ levonorgestelt tartalmaz, 5 évre tervezett alkalmazási időtartamra 14 $\mu \mathrm{g} / \mathrm{nap}$ felszabadulási sebességgel, míg a hagyományos tablettákkal napi 50$100 \mu \mathrm{g}$ kerül bevitelre).

Hüvelyben alkalmazható szivacsokat is formuláltak. Ezek előállítása és alkalmazásuk elve nagyon hasonlít a hüvelytamponokéra. Általában lágy poliuretán szivacsok, melyek egy hatóanyag-tartalmú géllel vagy

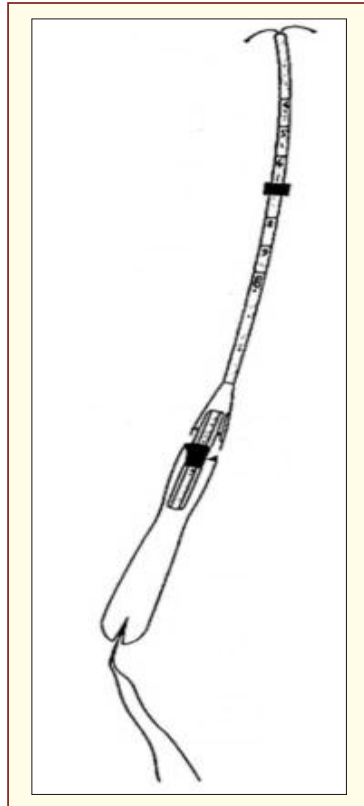

2. ábra: Mirena intrauterin rendszer 
folyadékkal (oldat vagy diszperzió) vannak impregnálva. Ezt elsősorban fogamzásgátlás céljából hozzák forgalomba (de a rendszer egyéb hatóanyagok inkorporálására is alkalmas). Több előnyös tulajdonsággal rendelkezik, mivel fizikai gátként is funkcionál, illetve az inkorporált hatóanyag spermicid és esetleg vírusölö aktivitással is bírhat [22]. Az impregnáló készítményben segédanyagként gélképző (metilcellulóz), diszpergáló (poli-dimetilsziloxán), tartósító (benzoesav, szorbinsav és származékai), valamint antioxidáns (nátrium-diszulfit) komponensek kerülhetnek alkalmazásra. Állatgyógyászati készítmények között is népszerü megoldás.

Különböző multipartikuláris hordozókat (pl. politejsav-poliglikolsav mikropartikulumok) vagy mukoadhezív rendszereket tartalmazó készítmények alkalmasak akár vaginális vakcinák formulálására is. Elsősorban az urogenitális rendszer infekciói (pl. Candida albicans) ellen kifejlesztett rendszerek találhatók meg az irodalomban [23].

\section{Egyéb készítmények}

A hüvelyben alkalmazott készítményeknél mindenképpen célszerü megemlíteni a nem gyógyszer kategóriába sorolható, gyógyszertárakban, drogériákban, hipermarketekben és az interneten is szabadon forgalmazható készítményeket. A tudatos alkalmazás esetén ezek a készítmények hozzájárulhatnak a megfelelő intim higiénéhez, de a fent említett szempontok figyelmen kívül hagyása a tünetek súlyosbodását (vagy újak kiváltását) okozhatja. A gyakran egy termékcsaládba tartozó törlőkendők, ún. krémes lemosók, szappanok, lemosóhab, hintőpor elsősorban nem is a hüvely, hanem a nemi szervek külső kezelésére, tisztántartására szolgálnak, bár alkalmazásuk során a hüvely nyálkahártyán kifejtett hatásuk bizonyos esetekben elkerülhetetlen.

A termékek formulálása során hasonló segédanyagok kerülnek felhasználásra, mint az adott gyógyszerforma (pl. oldat, hüvelykúp) esetén, bár néhány különbséget érdemes kiemelni. Általában a savas komponensek (általában tejsav) mellett nagyszámú segédanyag (több mint a gyógyszereknél) található bennük. A lemosókban előszeretettel alkalmazzák a nátrium-lauril-szulfátot, mely nyálkahártya-irritáló hatása miatt kerülendő komponens (a vaginális gyógyszerformákban elvétve alkalmazzák). Az illatanyagok és az allergizáló tartósítószerek (benzoesav és származékai) is nagyobb gyakorisággal kerülnek alkalmazásra, mint a forgalomba hozatali engedéllyel rendelkező gyógyszereknél.

A hüvelyi síkosítóknál elsősorban a karbomer-gélek jönnek számításba, de a cellulóz étereket (hidroxi-etilcellulóz) is használják. Ezek az esztétikus hidrogélek a beszáradást megelőzendő folyadékmegkötő komponenseket (glicerin, propilénglikol), tartósítószereket, valamint a karbomer esetén a gélszerkezet kialakításához szükséges lúgosító komponenst (pl. nátrium-hidroxid, trietanolamin) mindenképpen tartalmaznak.

A fenti termékek ajánlása előtt célszerü az összetételeket és az alkalmazási javallatokat részletesen megismerni, mivel találkozhatunk olyan megoldásokkal, melyek tudományos alapjai nem eléggé megalapozottak. Például létezik olyan intim-zuhany (zuhanyrózsa helyére csatlakoztatható), mely elsősorban növényi hatóanyagokat tartalmazó „kapszulán” (nem a gyógyszerkönyvi kritériumoknak megfelelő vaginális kapszulát kell érteni alatta) keresztül juttat nagymennyiségü folyadékot (akár 4-5 liter) a hüvelybe. A bevezetöben bemutatott problémák következtében az ilyen termékek hatékonysága a gyakori, kontroll nélküli alkalmazás mellett bizony megkérdőjelezhető. Léteznek olyan intim törlőkendők is, melyek a gyártó leírása alapján enyhén lúgos kémhatásúak. Ennek a tulajdonságnak a fiziológiailag hasznos voltára szintén nem találtunk bizonyítékot.

\section{Összefoglalás}

Célunk az volt, hogy egy olyan összeállítást készítsünk, mely segít eligazodni a hüvelyben alkalmazható gyógyszerformák között. Ehhez a legújabb gyógyszerkönyvi besorolást alkalmaztuk. Törekedtünk az ezen készítmények formulálási lehetőségeinek és alkalmazható segédanyagainak rendszerezésére, mely reményeink szerint nemcsak a magisztrális gyógyszerkészítés során a formuláláskor lehet segítség, hanem a gyári készítmények expediálásakor a megfelelő információnyújtásban is.

\section{IRODALOM}

Az 1-23. sz. irodalom az MGYT honlapjáról (www.mgyt.hu) letölthető és kérésre a szerkesztőség az érdeklődőknek megküldi.

\section{G. B a k i, J. B a j d i k: Vaginal dosage forms}

Szegedi Tudományegyetem, Gyógyszertechnológiai Intézet, Szeged, Eötvös u. 6. -6720 
IV 


\title{
Formulation of a solid intravaginal matrix system to prolong the pH-decreasing effect of lactic acid
}

\author{
G. Baki, J. Bajdik, A. Kelemen, K. Pintye-Hódi*
}

Department of Pharmaceutical Technology, University of Szeged, Eötvös u. 6, H-6720 Szeged, Hungary *Correspondence: klara.hodi@ pharm.u-szeged.hu

\begin{abstract}
The aim of our work was to study the applicability of solid matrix systems for the formulation of long-acting intravaginal tablets containing lactic acid. These systems were compressed from matrix granules containing hydroxypropylmethyl cellulose (HPMC), lactose monohydrate and microcrystalline cellulose (MCC, the binder and carrier of lactic acid) as additives. The active pharmaceutical ingredient (API) was incorporated into the granulating fluid and the effect of its concentration (evaluated up to 15\%) on the pH-decreasing effect of the tablets was assessed. The particle size and mechanical properties of the granules did not change relevantly. The dissolution of the active component (change in $H^{+}$ concentration) was tested with a modified dissolution test for $8 \mathrm{~h}$. The $\mathrm{pH}$-decreasing effect of tablets was influenced by the lactic acid content. It was the highest for samples containing the largest amount of lactic acid. The cumulative concentration of dissolved $\mathrm{H}^{+}$was plotted, which curve exhibited a break at about $4 \mathrm{~h}$. Up to this time, the shape of the tablets constantly changed (a hemisphere was formed) at every sample, after this time no change in shape could be detected. It can be concluded that in the first stage of dissolution erosion was the main factor influencing the liberation of the API. This is necessary for the detachment of lactic acid from the insoluble MCC. A relatively quick liberation was detected in the initial period (0-4 h) for the samples containing a small amount of lactic acid, which can be explained by the simpler liberation of API. Below 9\% lactic acid, the readier liberating sites of the carrier were saturated. In the later stage of dissolution (5-8 $\mathrm{h})$, the slower processes were more relevant. Additionally, it can be stated that the composition applied was appropriate for the formulation of a long-acting matrix system containing lactic acid.
\end{abstract}

Key words: High-shear granulator - HPMC - Intravaginal matrix system - Lactic acid - pH-decreasing effect.

Despite the paucity of glands, the vaginal epithelium is usually kept moist by a surface film. This film, known as vaginal fluid, consists of cervical mucus, exfoliated cells from the vagina itself and also small amounts of the secretion from the Bartholin's glands in the vaginal wall. Transudation from the blood vessels through the intracellular channels to the lumen can also contribute to the chemical composition. The quantity of this liquid is about $3-4 \mathrm{~g}$, but varies during the normal menstrual cycle. The vaginal secretion, which serves as a protective barrier against infections, contains a variety of antimicrobial substances, carbohydrates, acids and proteins. Typically, the vaginal $\mathrm{pH}$ in mature, healthy women has a $\mathrm{pH}$ in the range $4.0-5.0$. The $\mathrm{pH}$ in the vaginal lumen is controlled primarily by lactic acid formed from cellular glycogen, or by carbohydrates produced by the action of the normal vaginal microflora. The acidity plays a clinically important role in preventing the proliferation of pathogenic bacteria.

The natural aging process results in significant changes in the vagina, including a decrease in vaginal size, loss of elasticity, loss of vascularity and a thinning of the mucosa. Vaginal secretions become scant and watery, and the $\mathrm{pH}$ increases from 4.0-5.0 to 7.0-7.4. Resistance to bacterial and fungal infections is reduced due to the lower population of acidophilic organisms. As there is a correlation between the $\mathrm{pH}$ of the vaginal secretions and the inhibition of Chlamydial infections, maintenance of the optimum $\mathrm{pH}$ of the vaginal fluid is therefore inevitable [1].

Different acidic liquids are applied as irrigation fluids, but a large amount of such a liquid can cause the washing-out of the Lactobacillus flora and the effects of these materials are not long-lasting, therefore, the application of such a liquid is uncomfortable. Solid preparations containing various Lactobacillus species and other lactic acid-producing organisms have been used in the treatment of vaginal disorders, but evidence to support this use is limited [2]. Because of this situation, the formulation of a solid dosage form containing a long-acting acidifying component - if possible lactic acid - is reasonable.
Different solid matrix systems, mainly tablets are popular nowadays because of their controlling effects on the dissolution of APIs [3]. These tablets can be prepared through the direct compression of a powder mixture containing a matrix former or through the compression of granules (generally the matrix granules) [4]. Vaginal dosage forms have been developed and used clinically for many years in local therapy and systemic delivery of systemically effective drugs. Intravaginal preparations can be applied to treat various topical problems, because of the good absorption and the lack of a first pass effect, this route can be utilized to cure systemic diseases, mainly by hormone replacement [5-7].

Novel intravaginal delivery systems include those that employ bioadhesive materials. Bioadhesive properties of compounds, such as hydrogels may provide a controlled delivery system with a prolonged residence and intimate contact in the vagina. Many hydrophilic polymers and hydrogels have been used in vaginal products. These include chitosan, acrylic components and cellulose derivatives (such as hydroxylpropylmethyl cellulose, hydroxylpropyl cellulose) and mixtures of these [8-10]. Most of these materials can be used to produce a hydrophilic matrix system [11]. Furthermore, intravaginal therapeutic systems must contain such materials that ensure the appropriate release of the active ingredients $[12,13]$. The matrices can contain other materials, but the biocompatibility (e.g. irritation-free) is very important for the vaginal forms, as the intact mucous membrane and the bacterial flora protect the vagina against infections [14].

Since lactic acid has favorable effects, its incorporation into a solid dosage form can be very beneficial, and it is well-known that a small amount of liquid can be formulated into tablets. In this case, the liquid is incorporated into the granulating fluid and the application of components which can bind this material is also necessary [15]. In this study, the applied systems contained HPMC as matrix-forming agent, together with lactose monohydrate and MCC. The fibers of the filler/binder MCC were used to bind the liquid and it therefore 
acted as a carrier [16]. Different aqueous solutions of lactic acid were used as granulating liquids, and the processes were performed in a high-shear granulator. The mechanical properties of granules were determined via the friability test which was performed in a shaking bottle containing steel balls [17]. The hydrophilic matrix granules were compressed into tablets $13 \mathrm{~mm}$ in diameter. The $\mathrm{pH}$-decreasing effect of this matrix system was controlled for 8 hours. The amount of physiological dissolution medium is so low that the prescribed test for tablets in the Eur. Ph. would not have given accurate information; therefore a special dissolution test was performed. $4 \mathrm{~mL}$ of phosphate buffer ( $\mathrm{pH} 4.5$ ) was used in in vitro tests as dissolution medium which is equivalent with the $\mathrm{pH}$ of vaginal fluid $(\mathrm{pH} 4.56 \pm 0.01)$. The test liquid was removed after every hour.

The aim of the work was to study the applicability of solid matrix systems for the formulation of long-acting tablets containing lactic acid. The effect of the lactic acid concentration on the $\mathrm{pH}$-decreasing effect of the tablets was also evaluated.

\section{MATERIALS AND METHODS \\ 1. Materials}

HPMC (Pharmacoat 606, Shin-Etsu Chemical Co., Ltd., Tokyo, Japan) was used as matrix former. This component is frequently utilized to form intravaginal bioadhesive systems $[18,19]$. Our preformulation studies indicated that the optimum concentration of this component was $30 \%$. Microcrystalline cellulose (Vivapur 301, Rettenmaier\&Söhne $\mathrm{GmbH}$, Rosenberg, Germany) was applied as filler/binder, and lactose monohydrate (Eur. Ph., $5^{\text {th }}$ edition) as filler. Solid vaginal products often contain lactose as filler, since this is a natural substrate for the vaginal microflora (Lactobacillus), which converts lactose into lactic acid [20]. The quantity of each of these components was $35 \%$. The API was lactic acid (Eur. Ph.) as a pH-decreasing component.

\section{Preparation of matrix granules}

Granules were prepared in a high-shear granulator (ProCepT 4M8 granulator, ProCepT nv, Zelzate, Belgium). In accordance with our previous results, the quantity of liquid was 35 to $100 \mathrm{~g}$ of powder mixture. The composition of the granulating fluid varied (Table I). The operational parameters were as follows: impeller speed: $1,500 \mathrm{rpm}$; chopper speed: 3,500 rpm; liquid dosing speed: $15 \mathrm{~mL} / \mathrm{min}$; spheronization time: $4 \mathrm{~min}$; mass of powder mixture: $150 \mathrm{~g}$; granules were dried on trays at $40^{\circ} \mathrm{C}$ for $24 \mathrm{~h}$.

Table I - Composition of granulating fluid.

\begin{tabular}{|c|c|c|c|c|c|c|}
\hline \multirow{2}{*}{$\begin{array}{c}\text { Sam- } \\
\text { ple }\end{array}$} & \multirow{2}{*}{$\begin{array}{c}\text { Conc. } \\
\text { of lactic } \\
\text { acid (\%) }\end{array}$} & \multicolumn{4}{|c|}{ Content of tablets $(\mathrm{mg})$} & $\mathrm{pH}$ \\
\cline { 3 - 6 } & Lactic & HPMC & $\begin{array}{c}\text { Lactose } \\
\text { acid }\end{array}$ & MCC & \\
\hline S0 & 0 & 0 & 300 & 350 & 350 & 4.97 \\
S1 & 3 & 10.4 & 296.9 & 346.4 & 346.4 & 2.17 \\
S2 & 6 & 20.6 & 293.8 & 342.8 & 342.8 & 1.99 \\
S3 & 9 & 30.5 & 290.8 & 339.3 & 339.3 & 1.88 \\
S4 & 12 & 40.3 & 287.9 & 335.9 & 335.9 & 1.81 \\
S5 & 15 & 49.9 & 285.0 & 332.5 & 332.5 & 1.72 \\
\hline
\end{tabular}

\section{Study of granules}

Sizes and size distributions of the granules were assessed after drying. An analytical sieve (Retsch $\mathrm{GmbH}, \mathrm{Haan}, \mathrm{Germany}$ ) was used for these experiments. The $D_{50}$ values of the samples were determined with sieving system software (Retsch EasySieve 2.0).

Friability was applied to determine the mechanical properties of granules. Three grams of pellets $(>1.2 \mathrm{~mm})$ was placed into a $60-\mathrm{mL}$ bottle, together with 3 stainless steel balls $10 \mathrm{~mm}$ in diameter. The bottle was then placed in a rotating shaker mixer (Turbula, Willy A. Bachofen Masinenfabrik, Basel, Switzerland) that operated at $50 \mathrm{rpm}$ for $5 \mathrm{~min}$. The abraded samples were sieved on a $400-\mu \mathrm{m}$ sieve. The measurements were made in triplicate.

\section{Preparation of matrix tablets}

The tablets were prepared with a hydraulic press (Specac Inc, Graseby, UK). Round and flat punches $13 \mathrm{~mm}$ in diameter were used. $1 \mathrm{~g}$ of granules (1.2-2.0 $\mathrm{mm}$ in diameter) was pressurized at 5 tons. The comprimates were stored in a desiccator before the tests.

\section{Study of tablets}

The diameter and height of the tablets were measured with a screw micrometer with an accuracy of $0.001 \mathrm{~mm}$ (Mitutoyo, Japan). Ten tablets were tested.

The friability tests were performed in Erweka friabilator (Erweka $\mathrm{GmbH}$, Heusenstamm, Germany). The weight loss was determined after 100 rotations

\section{In vitro evaluation of released lactic acid}

This was a special test because of the above mentioned reason, in which a tablet was placed into a $25-\mathrm{mL}$ glass beaker and immersed into a water bath which ensured $37 \pm 1^{\circ} \mathrm{C}$. Four millilitres of phosphate buffer (Eur. Ph.) was applied as dissolution medium ( $\mathrm{pH} 4.56 \pm$ 0.01 ), which is a commonly used dissolution liquid in such systems [21-23]. The test liquid was removed after every hour and replaced with $4.00 \mathrm{~mL}$ fresh buffer. The testing period was $8 \mathrm{~h}$. The $\mathrm{pH}$ of the liquid was measured with a $\mathrm{pH}$ tester (WinLab $\mathrm{pH}-\mathrm{Meter}$, WindausLabortechnik GmbH \& Co. KG, Clausthal-Zellerfeld, Germany). The dissolution of the acidic component was monitored via the change in $\mathrm{H}^{+}$in the dissolution medium. Three parallel tests were performed. For bioadhesive vaginal solid dosage forms, one part of the preparation is attached to the mucous membrane and this part cannot erode during application. We tried to model the conditions present in the vaginal lumen. This is more of a functionality test but is the most similar to actual conditions.

\section{RESULTS AND DISCUSSION \\ 1. Properties of granules}

Size and size distribution of the prepared matrix granules were very similar for all the samples (Table II). The proportion of the applied fraction (1.2-2.0 $\mathrm{mm}$ in diameter) was nearly $45-50 \%$. The presence of lactic acid in the granulating fluid did not alter the particle size distribution of the products. The mechanical properties of the products did not change relevantly either. Friability was $<5 \%$ in every case.

Table II - Parameters of granules.

\begin{tabular}{|c|c|c|c|}
\hline Sample & $\mathrm{D}_{50}(\mathrm{~mm})$ & $\begin{array}{c}\text { Proportion of } \\
\text { optimum fraction (\%) }\end{array}$ & Friability (\%) \\
\hline S0 & 1.222 & 46.6 & $3.30 \pm 0.15$ \\
S1 & 1.245 & 50.2 & $2.99 \pm 0.16$ \\
S2 & 1.178 & 46.2 & $2.73 \pm 0.09$ \\
S3 & 0.995 & 44.9 & $2.94 \pm 0.07$ \\
S4 & 1.256 & 48.2 & $4.06 \pm 0.03$ \\
S5 & 1.289 & 46.5 & $3.40 \pm 1.21$ \\
\hline
\end{tabular}

\section{Tablet properties}

All the investigated parameters were very similar for each sample (Table III). Weight, height and diameter were the same for every composition. Friability was $<0.1 \%$ in every case and it can therefore be stated that abrasion is negligible.

\section{Dissolution test}

Each of the samples exhibited very similar behavior in the dissolution medium. Swelling of the tablets and erosion of the samples could be detected in the liquid (Figure 1). It can be seen from the pictures 
Table III - Parameters of tablets.

\begin{tabular}{|c|c|c|c|c|}
\hline Sample & Weight $(\mathrm{g})$ & $\begin{array}{c}\text { Height } \\
(\mathrm{mm})\end{array}$ & $\begin{array}{c}\text { Diameter } \\
(\mathrm{mm})\end{array}$ & $\begin{array}{c}\text { Friability } \\
(\%)\end{array}$ \\
\hline S0 & $1.0048 \pm 0.0084$ & $5.626 \pm 0.039$ & $12.986 \pm 0.005$ & 0.01 \\
S1 & $1.0044 \pm 0.0058$ & $5.669 \pm 0.036$ & $12.994 \pm 0.009$ & 0.01 \\
S2 & $1.0024 \pm 0.0081$ & $5.667 \pm 0.038$ & $12.994 \pm 0.011$ & 0.01 \\
S3 & $1.0117 \pm 0.0139$ & $5.730 \pm 0.073$ & $12.992 \pm 0.002$ & 0.03 \\
S4 & $0.9961 \pm 0.0126$ & $5.660 \pm 0.061$ & $12.993 \pm 0.003$ & 0.06 \\
S5 & $1.0003 \pm 0.0064$ & $5.689 \pm 0.028$ & $12.999 \pm 0.004$ & 0.02 \\
\hline
\end{tabular}

that the shape constantly changed during the test. The main alteration could be seen after $4 \mathrm{~h}$. Before this point, a mainly cylindrical shape could be detected, but after this time the edges of the comprimates had disappeared because of the constant erosion. It is well known that the edges of tablets are mechanically weak points. After hemisphere formation, no further change in shape was detected. At the end of the dissolution, dry granules could be observed in the inner structure of the sample (Figure 2).

It can be seen from the results of the dissolution tests that the sample without API (SO) did not change the $\mathrm{pH}$ of test liquid ( $\mathrm{Ta}$ ble $I V$ ). However, lower values were clearly detected for the samples containing larger amounts of lactic acid. The $\mathrm{pH}$-decreasing effect of tablets diminished during every hour.

The concentration of $\mathrm{H}^{+}$(in $\mathrm{mol} / \mathrm{dm}^{3}$ ) was calculated from the $\mathrm{pH}$ (Table $V$ ). The increasing acidity of test liquid for samples containing larger amounts of API led to more spectacular differences than the change in $\mathrm{pH}$.

The quantity of $\mathrm{H}^{+}$in $4.00 \mathrm{~mL}$ liquid can be calculated from the previous results (Table VI). The basis value of the phosphate buffer (pH 4.56) was $1.10210^{-7} \mathrm{~mol}$. The $\mathrm{H}^{+}$excess of samples is summarized in Table VI.

The cumulative amount of $\mathrm{H}^{+}$was calculated and hence the dissolution curve could be plotted (Figure 3). The changes in characteristic of curve cannot be explained with the geometrical and mechanical properties of the tablets. As these parameters were constant in every sample, the results of the dissolution test are properly comparable.

It is well known that the dissolution of an API from a hydrophilic matrix system is controlled by both erosion and diffusion; and several mathematical methods can be used to describe their significance [24-

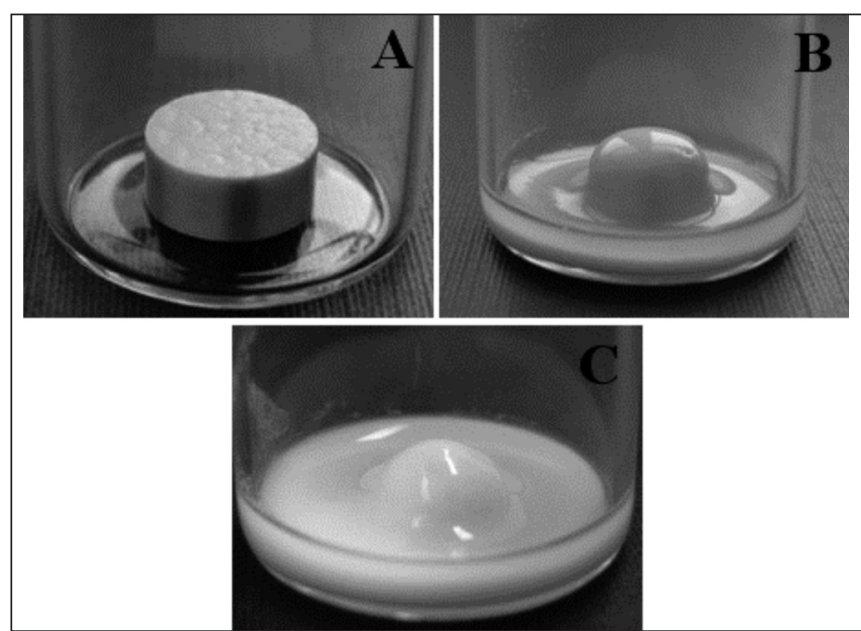

Figure 1 - Change in tablets during the dissolution test (A: starting tablet, B: after $4 \mathrm{~h}, \mathrm{C}$ : after $8 \mathrm{~h}$ ).

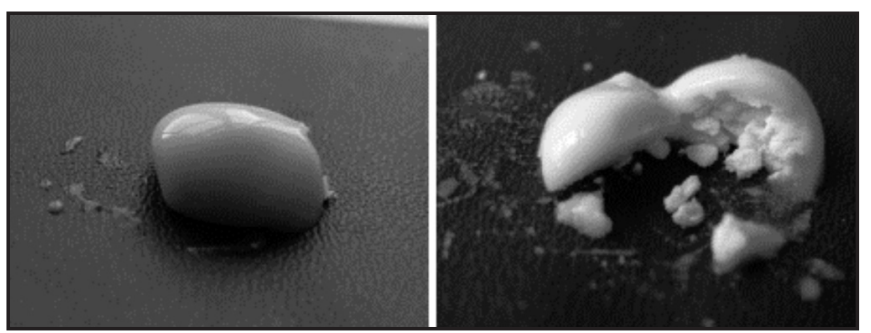

Figure 2 - Inner structure of the tablet after $8 \mathrm{~h}$.

27]. In this case, not only these processes must be considered, but also the liberation of API from the carrier. The other problem with the evaluation of the effects of these factors was the constant deterioration of the shape. For instance, the Hopfenberg dissolution kinetic model emphasizes the significance of the shape of the dosage form [28], but in this case, this property cannot be exactly determined during the constant change (from cylindrical to spherical). Because of change in the shape of the tablet, there was a break on the curves at about $4 \mathrm{~h}$ for each of the samples. A simple linear (zero-order) approach was

Table IV - $\mathrm{pH}$ of the dissolution medium.

\begin{tabular}{|c|c|c|c|c|c|c|}
\hline Time (h) & So & $\mathrm{S} 1$ & $\mathrm{~S} 2$ & S3 & S4 & S5 \\
\hline 1 & $4.59 \pm 0.07$ & $3.52 \pm 0.01$ & $3.31 \pm 0.03$ & $3.33 \pm 0.01$ & $3.24 \pm 0.02$ & $3.22 \pm 0.04$ \\
\hline 2 & $4.58 \pm 0.04$ & $3.60 \pm 0.06$ & $3.47 \pm 0.04$ & $3.41 \pm 0.02$ & $3.37 \pm 0.03$ & $3.32 \pm 0.02$ \\
\hline 3 & $4.56 \pm 0.02$ & $3.62 \pm 0.04$ & $3.52 \pm 0.03$ & $3.49 \pm 0.03$ & $3.41 \pm 0.01$ & $3.36 \pm 0.02$ \\
\hline 4 & $4.56 \pm 0.01$ & $3.69 \pm 0.04$ & $3.53 \pm 0.03$ & $3.53 \pm 0.01$ & $3.42 \pm 0.04$ & $3.39 \pm 0.01$ \\
\hline 5 & $4.56 \pm 0.01$ & $3.84 \pm 0.02$ & $3.62 \pm 0.01$ & $3.55 \pm 0.02$ & $3.48 \pm 0.02$ & $3.43 \pm 0.01$ \\
\hline 6 & $4.56 \pm 0.01$ & $4.01 \pm 0.02$ & $3.67 \pm 0.06$ & $3.62 \pm 0.04$ & $3.59 \pm 0.03$ & $3.55 \pm 0.04$ \\
\hline 7 & $4.56 \pm 0.02$ & $4.03 \pm 0.05$ & $3.77 \pm 0.05$ & $3.65 \pm 0.06$ & $3.61 \pm 0.03$ & $3.56 \pm 0.04$ \\
\hline 8 & $4.57 \pm 0.01$ & $4.13 \pm 0.06$ & $3.87 \pm 0.02$ & $3.70 \pm 0.01$ & $3.63 \pm 0.02$ & $3.58 \pm 0.01$ \\
\hline
\end{tabular}

Table V - The concentration of $\mathrm{H}^{+}\left(\mathrm{mol} / \mathrm{dm}^{3}\right)$.

\begin{tabular}{|c|c|c|c|c|c|}
\hline Time & S1 & S2 & S3 & S4 & S5 \\
\hline 1 & $3.02010^{-4}$ & $4.89810^{-4}$ & $4.71310^{-4}$ & $5.71110^{-4}$ & $6.07210^{-4}$ \\
2 & $2.53110^{-4}$ & $3.41410^{-4}$ & $3.86110^{-4}$ & $4.26610^{-4}$ & $4.78610^{-4}$ \\
3 & $2.38110^{-4}$ & $3.04310^{-4}$ & $3.23610^{-4}$ & $3.86110^{-4}$ & $4.33210^{-4}$ \\
4 & $2.06510^{-4}$ & $2.95110^{-4}$ & $2.98510^{-4}$ & $3.83110^{-4}$ & $4.10510^{-4}$ \\
5 & $1.45610^{-4}$ & $2.39910^{-4}$ & $2.85110^{-4}$ & $3.31110^{-4}$ & $3.74410^{-4}$ \\
6 & $9.69810^{-5}$ & $2.12210^{-4}$ & $2.39910^{-4}$ & $2.57010^{-4}$ & $2.84010^{-4}$ \\
7 & $9.33310^{-5}$ & $1.68510^{-4}$ & $2.22210^{-4}$ & $2.43610^{-4}$ & $2.75410^{-4}$ \\
8 & $7.41310^{-5}$ & $1.33910^{-4}$ & $1.98010^{-4}$ & $2.34410^{-4}$ & $2.65010^{-4}$ \\
\hline
\end{tabular}

Table VI - Quantity of $\mathrm{H}^{+}$excess in $4.00 \mathrm{~mL}$ of dissolution medium (mol).

\begin{tabular}{|c|c|c|c|c|c|}
\hline Time & S1 & S2 & S3 & S4 & S5 \\
\hline 0 & 0 & 0 & 0 & 0 & 0 \\
1 & $1.09810^{-6}$ & $1.84910^{-6}$ & $1.77510^{-6}$ & $2.17410^{-6}$ & $2.31810^{-6}$ \\
2 & $9.02210^{-7}$ & $1.25610^{-6}$ & $1.43410^{-6}$ & $1.59610^{-6}$ & $1.80410^{-6}$ \\
3 & $8.42110^{-7}$ & $1.10710^{-6}$ & $1.18410^{-6}$ & $1.43410^{-6}$ & $1.62310^{-6}$ \\
4 & $7.16010^{-7}$ & $1.07010^{-6}$ & $1.08410^{-6}$ & $1.42210^{-6}$ & $1.53210^{-6}$ \\
5 & $4.72410^{-7}$ & $8.49410^{-7}$ & $1.03010^{-6}$ & $1.21410^{-6}$ & $1.38710^{-6}$ \\
6 & $2.77810^{-7}$ & $7.38510^{-7}$ & $8.49410^{-7}$ & $9.18010^{-7}$ & $1.02610^{-6}$ \\
7 & $2.63110^{-7}$ & $5.64010^{-7}$ & $7.78510^{-7}$ & $8.64310^{-7}$ & $9.91510^{-7}$ \\
8 & $1.86410^{-7}$ & $4.25310^{-7}$ & $6.81910^{-7}$ & $8.27510^{-7}$ & $9.50010^{-7}$ \\
\hline
\end{tabular}




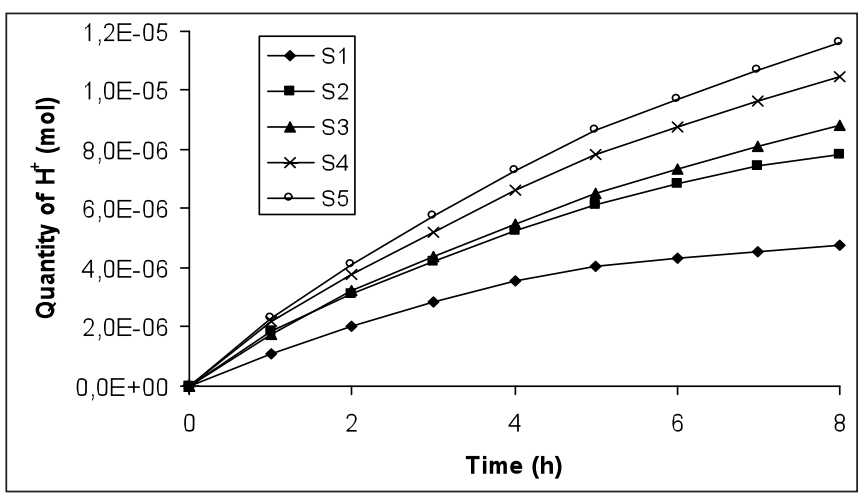

Figure 3 - Cumulative curve of dissolved $\mathrm{H}^{+}$-ion.

therefore used to describe the kinetics of both sections $(0-4 \mathrm{~h}$ and $5-8 \mathrm{~h})$.

Fitting of both linear sections was very good (Table VII). An increase in the absolute value of the slope of the linear section was detected for samples prepared with concentrated lactic acid solutions. There was a good correlation between $\mathrm{pH}$ of the granulating fluid and both slopes. It can be seen that the slope of the second section is lower than for the first. The ratio of these slopes was the lowest for S1 (28\%). It was higher for S2 (44\%) and S3 (57\%), but subsequently did not rise further (53\% for S4 and 55\% for S5).

Visual checking of the dissolution process revealed that erosion of the tablet could be detected. Erosion was not a disintegration process into granules, but a detachment of small particles, so that the liberation of lactic acid from the carrier could occur and the dissolved acidic component appeared in the medium. This process was quicker than the diffusion of the liberated API through the swollen polymer gel layer. Accordingly, the rate-limiting process of the dissolution in the starting period $(0-4 \mathrm{~h})$ was mainly erosion and the quicker liberation of active agent from the carrier. In the second stage (5-8 h), after sphere formation (see below), erosion of this surface was slower - further change in shape did not take place - and the rapidly released portion of lactic acid dissolved in the first stage. The concentration of dissolved $\mathrm{H}^{+}$was therefore lower in this period. This was indicated by the lower $\mathrm{pH}$-decreasing effect in this period. Thus, the significance of the slower phenomena, namely diffusion and the slower detachment of lactic acid was higher in this case.

The relative significance of erosion and the weaker interaction between the API and the carrier for S1 were demonstrated by the 4-fold faster dissolution in the first stage of the dissolution curve. Since there was no appreciable difference in the erosion behavior of the different tablets, the relevance of the first section for this sample could be explained as lactic acid was mainly enriched on the surface of the carrier and the detachment was easier. The structure of the MCC particle is loose - as seen in Figure 4 - and the liquid can therefore penetrate the interior, which can be closed during compression. Liberation of this active agent is more difficult. When the concentration of lactic acid reached a given level (about 9\%), saturation of the surface was detected. The readily removable sites were filled with lactic acid, while the other (included) parts of the liquid formed a new rate-limiting phenomenon. This explains the slower liberation in samples prepared with higher amount of API.

On the basis of this study, it can be stated that the composition applied was appropriate for the incorporation of a liquid active agent. It can be processed into the granulating fluid up to the concentration of $15 \%$, since the presence of API altered significantly neither the particle size distribution, nor the mechanical properties of the granules. The shape of tablets constantly changed during the first $4 \mathrm{~h}$ of the dissolu-
Table VII - Slopes of linear sections of dissolution curves.

\begin{tabular}{|l|c|c|c|c|}
\hline \multirow{2}{*}{} & \multicolumn{2}{|c|}{ Section 1 } & \multicolumn{2}{c|}{ Section 2 } \\
\cline { 2 - 5 } & Slope & $\mathrm{R}^{2}$ & Slope & $\mathrm{R}^{2}$ \\
\hline S1 & 0.866 & 0.9969 & 0.245 & 0.9962 \\
S2 & 1.293 & 0.9928 & 0.575 & 0.9926 \\
S3 & 1.357 & 0.9947 & 0.771 & 0.9988 \\
S4 & 1.628 & 0.9967 & 0.869 & 0.9997 \\
S5 & 1.798 & 0.9963 & 0.989 & 0.9998 \\
\hline
\end{tabular}

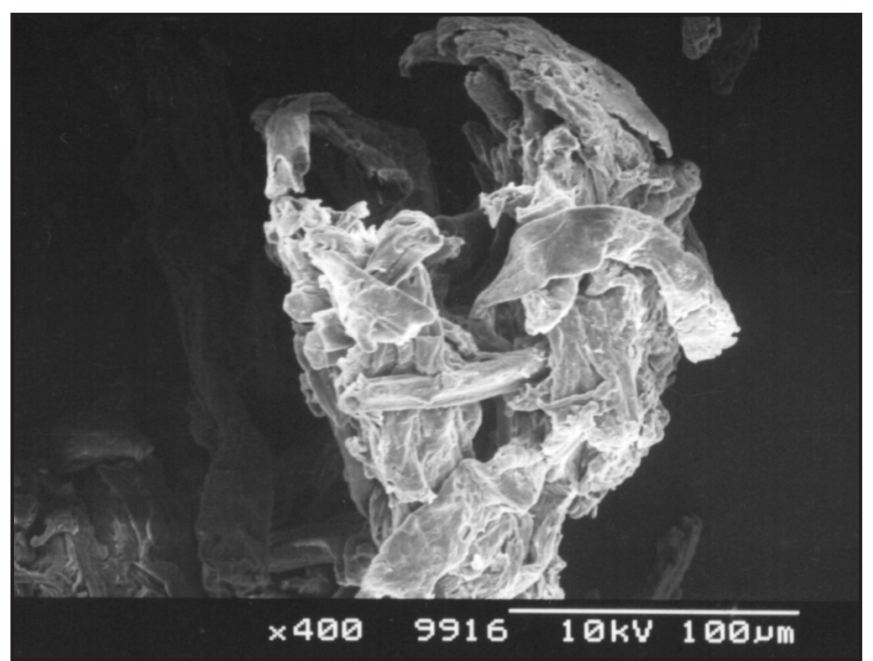

Figure 4 - Microcrystalline cellulose (SEM).

tion. After this, a hemisphere was formed and no further change was detected. Erosion and change in shape were very similar for each of the samples, independently of the concentration of lactic acid.

The $\mathrm{pH}$ of the dissolution medium was not decreased for the sample without active acidic component. The $\mathrm{pH}$-decreasing effect of the tablet was influenced by the concentration of lactic acid applied in the granulating fluid. It was the highest for samples containing the largest amount of API. The cumulative concentration of dissolved $\mathrm{H}^{+}$ was determined and plotted. These changes in shape of dissolution curve cannot be caused by the geometrical and mechanical properties of tablets, as these parameters were constant in every sample.

It can be concluded from these results that erosion is the main parameter responsible for the liberation of lactic acid from this system. This phenomenon increased the possibility of detachment of API from the insoluble carrier (MCC). This process was also an important step because a relatively rapid liberation could be detected in the initial period for the samples containing small amounts of lactic acid, which can be explained by the easier detachment of this component. When the concentration of lactic acid reached $9 \%$, these more readily liberating sites were saturated. In the second stage of dissolution (5-8 h), the relevance of erosion was lower and the slower processes, such as diffusion of API through the HPMC gel barrier became more significant.

Finally,it can be stated that a controlled-release intravaginal matrix tablet can be formulated from the matrix-former HPMC and the carrier MCC to ensure a long-acting preparation containing lactic acid.

\section{REFERENCES}

1. Hillary A.M., Llojd A.W., Swarbrick J. - Drug delivery and Targeting for Pharmacists on Pharmaceutical Scientists. - Taylor \& Francis, London, 2001.

2. ParfittK.-Martindale 32th edition, Pharmaceutical Press, London, 1999. 
3. Abdul S., Poddar S.S. - A flexible technology for modified release of drugs: multi layered tablets. - J. Control. Release, 97, 393-405, 2004

4. Singh S. K., Naini V. - Dosage forms: non parenteral. - In: Encyclopedia of Pharmaceutical Technology, $2^{\text {nd }}$ ed., Vol. 1, Swarbrick J., Boylan J.C. Eds., Marcel Dekker Inc., New York, 2002.

5. Hussain A., Ahsan F. - The vagina as a route for systemic drug delivery. - J. Control. Release, 103, 301-313, 2005.

6. Woolfson A.D., Malcolm R.K., Gallagher R.J. - Design of a silicone reservoir intravaginal ring for the delivery of oxybutynin. - J. Control. Release, 91, 465-476, 2003.

7. Crowder T.M., Hickey A.J., Loueym M.D., Orr N. - A Guide to Pharmaceutical Particulate Science. - Interpharm/CRC, Boca Raton, 2003.

8. Kast C.E., Valenta C., Leopold M., Bernkop-Schnürch A. Design and in vitro evaluation of a novel bioadhesive vagina drug delivery system for clotrimazole. - J. Control. Release, 81, 347-354, 2002

9. Karasulu H.Y., Hilmioglu S., Metin, D.Y. Güneri T. - Efficacy of a new ketoconazole bioadhesive vaginal tablet on Candida albicans. - II Farmaco, 59, 163-167, 2004.

10. Russo E., Parodi B., Caviglioli G., Cafaggi S., Bignandi G., Milani M., Prini M. - Development, characterization and preliminary clinical evaluation of mucoadhesive vaginal gels containing chlorhexidine digluconate. - J. Drug Del. Sci. Tec., 14, 489-494, 2004.

11. Vueba M.L., Batista de Carvalho L.A.E, Veiga F., Sousa J.J., Pina M.E. - Influence of cellulose ether polymers on ketoprofen release from hydrophilic matrix tablets. - Eur. J. Pharm. Biopharm., 58, 51-59, 2004.

12. Baloglu E., Özyazıcı M., Hızarcıoglu S.Y., Karavana H. A. - An in vitro investigation for vaginal bioadhesive formulations: bioadhesive properties and swelling states of polymer mixtures. - II Farmaco, 58, 391-396, 2003.

13. Valenta C. - The use of mucoadhesive polymers in vaginal delivery. - Adv. Drug Deliver. Rev., 57, 1692-1712, 2005.

14. Siepmann J., Peppas N.A. - Modeling of drug release from delivery systems based on hydroxypropyl methylcellulose (HPMC). - Adv. Drug Deliver. Rev., 48, 139-157, 2001.

15. Ritschel W.A., Bauer-Brandl A. - Die Tablette. - Editio Cantor Verlag, Aulendorf, 2002.

16. Aulton M.E. - Pharmaceutics, The Science of Dosage Form Design. - Churchill Ltd. Livingstone, 2002, pp. 334-359.
17. Tüske Zs., Regdon Jr. G., Eros I., Srcic S., Pintye-Hódi K. - The role of the surface free energy in the selection of a sutable excipient in the course of a wet-granulation method. - Powder Technol., 155, 139-144, 2005.

18. Chien Y.W., Lee C.H. - Drug delivery, Vaginal route. - In: Encyclopedia of Pharmaceutical Technology, $2^{\text {nd }}$ ed., Vol. 1, Swarbrick J., Boylan J.C. Ed., Marcel Dekker Inc., New York, 2002.

19. Rowe R.C., Sheskey P.J., Weller P.I. - Handbook of Pharmaceutical Excipients. - $4^{\text {th }}$ ed., Pharmaceutical Press, London, 2003.

20. das Neves J., Bahia M.F. - Gels as vaginal drug delivery systems. - Int. J. Pharm., 318, 1-14, 2006.

21. Wang L., Tang X. - A novel ketokonazole bioadhesive effervescent tablet for vaginal delivery: design, in vitro and 'in vivo' evaluation. - Int. J Pharm, 350, 181-187, 2008.

22. Özyazici M., Gökce E., Hizarcioglu S.Y., Taner M.S., Köseoglu K., Ertan G. - Dissolution and vaginal absorption characteristics of metronidazole and ornidazole. - Pharmazie, 61, 855-861, 2006.

23. Digenis G.A., Nosek D., Mohammadi F., Darwazeh N.B., Anwar H.S., Zavos P.M. - Novel vaginal controlled-delivery systems incorporating coprecipitates of nonoxynol-9. - Pharm. Dev. Technol., 4, 421-430, 1999.

24. Lin C.C., Metters A.T. - Hydrogels in controlled release formulations: Network design and mathematical modeling. - Adv. Drug Deliver Rev., 58, 1379-1408, 2006.

25. Huang X., Brazel C.S. - On the importance and mechanisms of burst release in matrix-controlled drug delivery systems. - J. Control. Release, 73, 121-136, 2001.

26. Jain J.P., Modi S., Domb A.J., Kumar N. - Role of polyanhydrides as localized drug carriers. - J. Control. Release, 103, 541-563, 2005.

27. Dredán J., Zelkó R., Antal I., Bihari E., Rácz I. - Effect of chemical properties on drug release from hydrophobic matrices. - Int. J. Pharm., 160, 257-260, 1998.

28. Costa P., Lobo J.M.S. - Modeling and comparison of dissolution profiles. - Eur. J. Pharm. Sci., 13, 123-133, 2001.

\section{MANUSCRIPT}

Received 5 September 2008, accepted for publication 15 December 2008. 

V 


\title{
Evaluation of powder mixtures and hydrophilic gastroretentive drug delivery systems containing zinc acetate and sodium bicarbonate
}

\author{
Gabriella Baki, János Bajdik, Klára Pintye-Hódi* \\ Department of Pharmaceutical Technology, University of Szeged, Eötvös u. 6, H-6720 Szeged, Hungary
}

\section{A R T I C L E I N F O}

\section{Article history:}

Received 28 July 2010

Received in revised form 13 October 2010

Accepted 29 October 2010

Available online 9 November 2010

\section{Keywords:}

Zinc acetate dihydrate

Sodium bicarbonate

Water uptake

Disintegration

Floating

Dissolution

\begin{abstract}
A B S T R A C T
The aim of this study was to develop and study floating controlled drug delivery systems consisting of a model drug (zinc acetate dihydrate), different forms of a matrix-forming polymer (Metolose $90 \mathrm{SH}$ ) and sodium bicarbonate as an effervescent component. The proportions of Metolose and bicarbonate were varied, and the effects of the different ratios on the properties of the resulting powders and tablets were determined. The water uptakes of different powder mixtures were initially evaluated. These tests indicated the interaction of the active and effervescent agent, this phenomenon leading to an unpredicted increase in the amount of liquid taken up. This interaction was evaluated as concerns the degradation of the hydrophilic matrix system. The disintegration of tablets with different compositions revealed that this interaction increases the time required for the disintegration of these systems. The study demonstrated that the interaction of the components induced significant changes in the parameters of this new sensitive delivery system. In the last steps, the buoyancy and dissolution properties of tablets that appeared appropriate for the formulation of a controlled drug delivery system were investigated.
\end{abstract}

(c) 2010 Elsevier B.V. All rights reserved.

\section{Introduction}

Zinc acetate has a wide range of medical and dietary applications, e.g. as a dietary supplement, as an adstringent [1] or in lozenges used to treat the common cold [2]. Zinc salts, e.g. the sulfate, gluconate or acetate, can also be used to treat zinc deficiencies. As an oral daily supplement, this metal ion is used for the treatment of Wilson disease, an inherited, copper accumulation disorder that affects about 30 individuals per million people [3]. It is due to a dysfunction of a copper-transporting ATPase [4,5], leading to an accumulation of copper, mainly in the liver, but also in the brain, cornea and kidney, and causing progressive hepatic and nervous system damage. In the treatment of this disease, different active agents and their combinations can be applied, depending on the severity of the symptoms [6]. Zinc was first used by Schouwink in The Netherlands in the early 1960s [7,8]. Zinc interferes with the uptake of copper from the gastrointestinal tract, and removes stored copper [9]. Zinc may also act by inducing elevated levels of metallothionein [10-12]. Dosing is in the order of milligrams of zinc: the necessary amount is $150 \mathrm{mg}$ of zinc per day. Thus, zinc sulfate, for instance, should be administered in a dose of $220 \mathrm{mg} /$ day three times daily [13]. The actual salt used does not make a difference with respect to efficacy, but may affect tolerability [14].

\footnotetext{
* Corresponding author. Tel.: +36 62545 576; fax: +36 62545571.

E-mail address: klara.hodi@pharm.u-szeged.hu (K. Pintye-Hódi).
}

Acetate may cause the least gastrointestinal distress, and gluconate may be more tolerable than sulfate. In the case of active agents with a short elimination half-life in the plasma, administration two or three times a day is necessary, but the compliance and tolerability of patients can be increased by developing a sustained-release system.

The primary site of absorption of exogenous zinc in the human is thought to be in the proximal small bowel $[15,16]$. In order to develop a desired sustained-release dosage form for zinc acetate, it is necessary to optimize both the residence time of the system in the gastrointestinal (GI) tract and the rate of release of the drug. Various approaches are used to increase the GI residence time, including mucoadhesive systems $[17,18]$, swellable systems [19] and flotation systems [20,21]. Floating drug delivery systems (FDDSs) remain buoyant in the stomach for a prolonged period of time because of their lower bulk density as compared with that of the aqueous medium. These systems can involve the use of carbonates and bicarbonates, for example [22-24]; when these come into contact with acidic aqueous media, carbon dioxide is generated and entrapped within the gelling hydrocolloid, causing the system to float. An FDDS is desirable for drugs with an absorption window in the stomach or in the upper small intestine [25]. These systems help in releasing the active agent continuously before it reaches the absorption window, thereby ensuring optimum bioavailability [26].

In our work, hydrophilic floating matrix tablets were prepared by direct compression. Compressed hydrophilic matrix tablets are 
commonly used as oral drug delivery systems because of their good compactibility. Drug release from these systems is controlled by the formation of a viscous layer around the tablet, which acts as a barrier by opposing the penetration of water into the tablet. The overall drug release is influenced not only by the drug solubility, but also by the physical and mechanical properties of the gel barrier. Besides the mechanism of drug release, the extents of matrix swelling and erosion, and the diffusion of the drug determine the kinetics [27].

For FDDSs, rapid hydration is a basic requirement. It is well known from the literature that Metolose matrices hydrate rapidly only at the surface [28], retaining the bubbles developing from sodium bicarbonate and extending flotation during $8 \mathrm{~h}$. The addition of sodium bicarbonate expands the volume of the matrices due to the gas bubbles formed after reaction with the acidic dissolution medium [29] and with the active agent, increasing their hydration volume.

In this study, a new FDDS based on the gas formation technique was developed. The tablets were prepared by direct compression, containing different ratios of an effervescent component (sodium bicarbonate) and different types of hydroxypropyl methylcellulose as matrix former. Zinc acetate dihydrate $(\mathrm{Zn}-\mathrm{ac})$, which is predominantly absorbed in the upper part of the GI tract, was used as active compound. It is known that interaction may occur between bicarbonates and $\mathrm{Zn}-\mathrm{ac}$ [30]; accordingly, the objective of this work was to prepare a controlled drug delivery system and to investigate the effects of the ingredients and their possible interaction on the properties of powder mixtures (water uptake) and tablets (disintegration, floating and dissolution). In this part of our work, only the technological aspects were studied. The chemical relevance and the background will be discussed later. Our aim was an evaluation of the effects of the components on the functioning and erosion of this hydrophilic floating system.

\section{Materials and methods}

\subsection{Materials}

Zn-acetate (Zn-ac) (Merck KGaA, Darmstadt, Germany) was chosen as active agent. Forms of hydroxypropyl methylcellulose (Metolose 90 SH 100 SR, 4000 SR, 100,000 SR, Shin-Etsu Chemical Co., Ltd., Tokyo, Japan) with different viscosities were used as matrix-former. This component is frequently utilized to form floating matrix systems [24,31]. The notations for the different (low, medium and high) viscosities of the Metolose used in this work were as the follows: 100 SR - LV, 4000 SR - MV and 100,000 SR $\mathrm{HV}$. Sodium bicarbonate ( $\mathrm{NaHCO}_{3}$, Solvay S.A., Brussels, Belgium) was applied as gas-forming agent. Lactose monohydrate (Ph. Eur., Hungaropharma Plc, Budapest, Hungary) was used to substitute $\mathrm{Zn}-\mathrm{ac}$ in the second part of the work.

\subsection{Preparation of powder mixtures}

As a preliminary step, the $\mathrm{Zn}$-ac and $\mathrm{NaHCO}_{3}$ were size-reduced in a mortar (Retsch RM 100, Retsch GmbH, Haan) for 10 min. Particle sizes were determined with an analytical sieve (Retsch $\mathrm{GmbH}$, Haan) and particles with diameters of $100-200 \mu \mathrm{m}$ were used in the study. The drug and the excipients were mixed in a rotating shaker mixer (Turbula, Willy A. Bachofen Maschinenfabrik, Basel) at $50 \mathrm{rpm}$ for $10 \mathrm{~min}$. The amount of active agent was calculated on the basis of the zinc requirement, which is equivalent to $500 \mathrm{mg}$ of $\mathrm{Zn}$-ac a day. The mass of the tablets prepared was $1 \mathrm{~g}$. Powder mixtures in every case contained $50 \% \mathrm{Zn}-\mathrm{ac}$, while the ratio of $\mathrm{NaHCO}_{3}$ and Metolose was varied as follows: 10:40\%, 15:35\%, 20:30\% and $25: 25 \%(w / w)$.

\subsection{Evaluation of water uptake}

The Enslin number, a simple semiquantitative measure of the water uptake of a powder, is the amount of fluid absorbed by $1 \mathrm{~g}$ of the powder (in $\mathrm{ml} / \mathrm{g}$ ). An Enslin apparatus with a glass filter and a pipette with $0.01 \mathrm{ml}$ accuracy were used for these experiments [32]. $0.1 \mathrm{~g}$ of the different forms of Metolose, $0.25 \mathrm{~g}$ of each powder mixture and $0.5 \mathrm{~g}$ each of $\mathrm{Zn}$-ac and $\mathrm{NaHCO}_{3}$ were tested; 5 parallel experiments were performed in every case.

\subsection{Preparation of matrix tablets}

Tablets were prepared with a hydraulic press (Specac Inc., Graseby, England); round and flat punches $13 \mathrm{~mm}$ in diameter were used. $1 \mathrm{~g}$ of powder mixture was compressed at $3 \times 10^{8} \mathrm{~Pa}$ with a dwell time of $10 \mathrm{~s}$. Additional excipients (lubricant and glidant) were not applied. In the second part of the work, powder mixtures containing lactose monohydrate instead of $\mathrm{Zn}$-ac were prepared; the ratio of the components was not changed.

\subsection{Study of matrix disintegration}

The disintegration of tablets was evaluated with a disintegration tester (Erweka ZT 71, Erweka GmbH, Heusenstamm, Germany), tablets were stored in a desiccator for $24 \mathrm{~h}$ before the test. The test liquid was gastric fluid ( $\mathrm{pH} \mathrm{1.2,} \mathrm{Ph.} \mathrm{Eur.)} \mathrm{and} \mathrm{the} \mathrm{temperature}$ was $37^{\circ} \mathrm{C}$. Twelve parallel experiments were performed. Each test was carried out for a maximum of $8 \mathrm{~h}$, as floating systems with a residence time in the stomach longer than $8 \mathrm{~h}$ are not reasonable [33].

\subsection{Buoyancy}

The buoyancy of the tablets was studied at $37 \pm 0.5^{\circ} \mathrm{C}$, in $150 \mathrm{ml}$ of gastric fluid at pH 1.2 ( $\mathrm{Ph}$. Eur.). The floating lag times (the duration of the period between the placing of the tablet in the medium and the tablet floating) and durations of tablet floating were determined by visual observation. Tablets were stored in a desiccator for $24 \mathrm{~h}$ before the test.

\subsection{Dissolution study}

The rates of in vitro release of $\mathrm{Zn}$-ac from the matrix tablets were determined in $900 \mathrm{ml}$ gastric acid ( $\mathrm{pH} \mathrm{1.2,} \mathrm{Ph.} \mathrm{Eur.)} \mathrm{by} \mathrm{the} \mathrm{pad-}$ dle method (Ph. Eur.). Tablets were stored in a desiccator for $24 \mathrm{~h}$ before the test. The paddle rotation speed was kept at $50 \mathrm{rpm}$, and the temperature at $37 \pm 0.5^{\circ} \mathrm{C}$. Dissolution tests were carried out under sink conditions. The motor activity of the stomach in the fed state is induced 5-10 min after the ingestion of a meal; the larger the amount of food ingested, the longer the period of fed activity, with usual time spans of 2-6 h, or more typically, 3-4h. The phasic contractions are similar to those seen during phase 2 of the interdigestive myoelectric motor complex (IMMC) in the fasting state [34]. Thus, the dissolution study was carried out for $4 \mathrm{~h}$. Three millilitre samples were withdrawn at $0.5,1,1.5,2,3$ and $4 \mathrm{~h}$, and the $\mathrm{Zn}$ contents were measured by X-ray fluoresence analysis (Philips MiniPal PW 4025, Philips Analytical, Almelo, The Netherlands). During the measurements, the conditions applied were $12 \mathrm{kV}$ and $100 \mu \mathrm{A}$, with a kapton filter and an air purge. The samples were measured during $60 \mathrm{~s}$, repeated in triplicate for each sample.

The concentrations of zinc ( $\mathrm{ppm}$ ) were calculated by means of linear calibration $\left(r^{2}=0.9945\right)$ from the intensities of the $K_{\alpha}$ lines of the detected radiation. The dissolved drug concentration was calculated on the basis of the zinc content of $\mathrm{Zn}$-ac. 


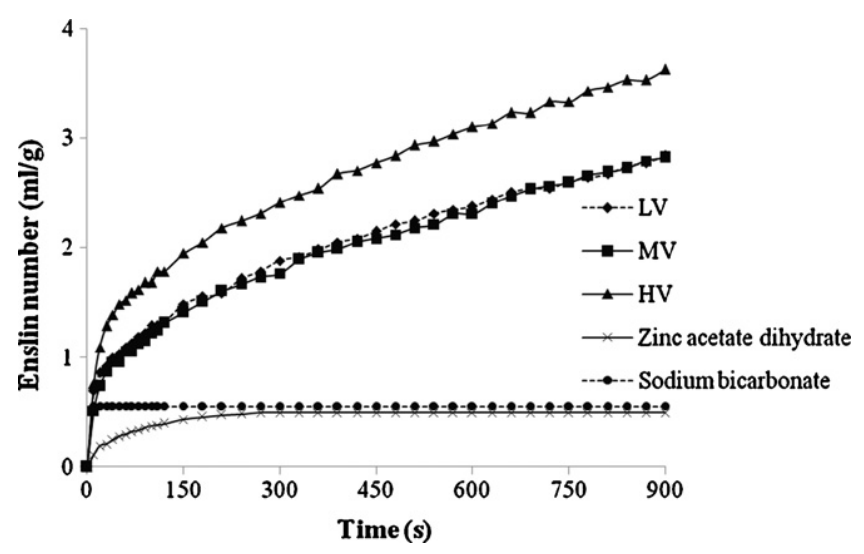

Fig. 1. Enslin numbers of active agent and excipients.

\section{Results and discussion}

\subsection{Water uptake of different powder mixtures}

For an understanding of the effects of the individual components on the water uptake of the system, the components and the binary and ternary powder mixtures were tested before the evaluation of the tablets. A requirement for floatable systems is that they should take up sufficient water to be able to enclose the developing air bubbles during the initial period of wetting. Thus, water uptake measurements were carried out for $15 \mathrm{~min}$.

First, the Enslin numbers of $\mathrm{Zn}$-ac and the excipients were determined (Fig. 1). The water uptakes of the different forms of Metolose were prolonged: for the LV and MV samples, the values were almost the same (LV: $2.838 \pm 0.055 \mathrm{ml} / \mathrm{g}$ and MV: $2.819 \pm 0.185 \mathrm{ml} / \mathrm{g}$ ), whereas the quantity of water was higher for the HV sample $(3.629 \pm 0.161 \mathrm{ml} / \mathrm{g})$. Their wetting was not finished by the end of the test. This was caused by the restriction of the gel layer of the swelling polymer. The process was very short in the case of $\mathrm{NaHCO}_{3}$; the water uptake occurred in the first $10 \mathrm{~s}$, after which the value was constant $(0.553 \pm 0.023 \mathrm{ml} / \mathrm{g})$. The active agent took up the maximum quantity of water in the first $6 \mathrm{~min}$, after which the value was constant $(0.493 \pm 0.031 \mathrm{ml} / \mathrm{g}$ ) (Fig. 1$)$.

Next, the water uptakes of the different binary and ternary powder mixtures were determined. The theoretical Enslin numbers were calculated from the Enslin numbers of each component in the ratio of their presence in the powder mixtures. Deviations from the calculated values were also determined. If a powder mixture took up the calculated maximum amount of water, there was no deviation, which meant a value of $100 \%$.

First, the water uptakes of the ternary powder mixtures were determined (Table 1 ). The quantity of water taken up increased with increasing amount of $\mathrm{NaHCO}_{3}$ in all cases. This change was unexpected as the Metolose content decreased with increasing amount of $\mathrm{NaHCO}_{3}$. It would appear obvious that $\mathrm{NaHCO}_{3}$ formed bubbles, which weakened the gel layer formed and the powder mixtures, so that they could hydrate more quickly.

Deviations from the calculated Enslin numbers were determined. Powder mixtures with $10 \% \mathrm{NaHCO}_{3}$ could not take up the calculated amount of water, and thus this ratio of $\mathrm{NaHCO}_{3}$ was not sufficient to modify the structures of the powders (Table 1). In contrast, all of the other powders took up much more water than expected (almost double the calculated value). This indicates that something happened when the powder mixture came into contact with water. $\mathrm{NaHCO}_{3}$ can react with acidic salts [35] such as $\mathrm{Zn}-\mathrm{ac}$, and carbonate salts are presumed to develop during the measurements.

For the evaluation of this situation, the binary mixtures were tested. When there was no $\mathrm{NaHCO}_{3}$ in the powder mixtures (Table 2), a lower quantity of water was taken up, confirming that $\mathrm{NaHCO}_{3}$ is required to change the structures of the powder mixtures and the gel layer of the polymer, enhancing the water uptake. $\mathrm{Zn}$-ac itself slowed down the water uptake and reduced the amount of water taken up.

For the binary powder mixtures containing only the additives, lower amounts of water were taken up as compared with the calculated values, clearly demonstrating that the active agent was also indispensable for the unpredicted wetting (Table 3). This phenomenon points to an interaction between $\mathrm{NaHCO}_{3}$ and $\mathrm{Zn}-\mathrm{ac}$, which enhances the water-uptake property of the powders.

The properties of powder mixtures without Metolose were also studied. The Enslin numbers of the 50:10, 50:15, 50:20 and 50:25 mixtures of $\mathrm{Zn}-\mathrm{ac}: \mathrm{NaHCO}_{3}$ were as follows: $0.666 \pm 0.023(132.32 \%$ deviation), $\quad 0.859 \pm 0.020 \quad(169.45 \%$ deviation $), \quad 1.079 \pm 0.073$ (211.43\% deviation) and $1.099 \pm 0.021$ (214.18\% deviation), respectively. These two components together ( $\mathrm{Zn}-\mathrm{ac}$ and $\mathrm{NaHCO}_{3}$ ) were able to take up more water than expected, confirming the occurrence of an interaction. At $20 \%$ and $25 \% \mathrm{NaHCO}_{3}$ contents,

Table 1

Enslin numbers $(\mathrm{ml} / \mathrm{g})$ (means $\pm \mathrm{SD}$ ) and deviation from calculated Enslin numbers (\%) of ternary powder mixtures.

\begin{tabular}{|c|c|c|c|c|c|c|}
\hline \multirow{2}{*}{$\begin{array}{l}\mathrm{Zn} \text {-ac: } \mathrm{NaHCO}_{3}: \text { Metolose } \\
(\%)(\mathrm{w} / \mathrm{w} / \mathrm{w})\end{array}$} & \multicolumn{2}{|l|}{ LV } & \multicolumn{2}{|l|}{ MV } & \multicolumn{2}{|l|}{ HV } \\
\hline & $\begin{array}{l}\text { Enslin number } \\
(\mathrm{ml} / \mathrm{g})\end{array}$ & Deviation (\%) & $\begin{array}{l}\text { Enslin number } \\
(\mathrm{ml} / \mathrm{g})\end{array}$ & Deviation (\%) & $\begin{array}{l}\text { Enslin number } \\
(\mathrm{ml} / \mathrm{g})\end{array}$ & Deviation (\%) \\
\hline $50: 10: 40$ & $1.383 \pm 0.061$ & 96.22 & $1.237 \pm 0.039$ & 86.54 & $1.571 \pm 0.023$ & 89.60 \\
\hline $50: 15: 35$ & $1.462 \pm 0.101$ & 110.55 & $1.474 \pm 0.119$ & 111.98 & $1.756 \pm 0.078$ & 109.75 \\
\hline $50: 20: 30$ & $1,927 \pm 0.059$ & 159.44 & $1.781 \pm 0.085$ & 147.37 & $1.996 \pm 0.185$ & 138.04 \\
\hline $50: 25: 25$ & $2.361 \pm 0.089$ & 215.76 & $1.929 \pm 0.104$ & 176.26 & $2.379 \pm 0.023$ & 184.17 \\
\hline
\end{tabular}

Table 2

Enslin numbers $(\mathrm{ml} / \mathrm{g})$ (means $\pm \mathrm{SD}$ ) and deviation from calculated Enslin numbers (\%) of binary powder mixtures without sodium bicarbonate.

\begin{tabular}{|c|c|c|c|c|c|c|}
\hline \multirow{2}{*}{$\begin{array}{l}\mathrm{Zn}-\mathrm{ac}: \mathrm{NaHCO}_{3}: \text { Metolose } \\
(\%)(\mathrm{w} / \mathrm{w} / \mathrm{w})\end{array}$} & \multicolumn{2}{|l|}{ LV } & \multicolumn{2}{|l|}{ MV } & \multicolumn{2}{|l|}{$\mathrm{HV}$} \\
\hline & $\begin{array}{l}\text { Enslin number } \\
(\mathrm{ml} / \mathrm{g})\end{array}$ & Deviation (\%) & $\begin{array}{l}\text { Enslin number } \\
(\mathrm{ml} / \mathrm{g})\end{array}$ & Deviation (\%) & $\begin{array}{l}\text { Enslin number } \\
(\mathrm{ml} / \mathrm{g})\end{array}$ & Deviation (\%) \\
\hline $50: 0: 40$ & $1.090 \pm 0.045$ & 71.01 & $1.104 \pm 0.048$ & 72.31 & $1.182 \pm 0.047$ & 62.66 \\
\hline $50: 0: 35$ & $1.077 \pm 0.071$ & 73.87 & $1.103 \pm 0.084$ & 76.02 & $1.196 \pm 0.040$ & 66.70 \\
\hline $50: 0: 30$ & $0.985 \pm 0.024$ & 71.75 & $1.102 \pm 0.083$ & 80.71 & $1.264 \pm 0.026$ & 75.71 \\
\hline $50: 0: 25$ & $0.957 \pm 0.001$ & 75.07 & $1.102 \pm 0.062$ & 86.84 & $1.316 \pm 0.118$ & 85.56 \\
\hline
\end{tabular}


Table 3

Enslin numbers $(\mathrm{ml} / \mathrm{g})$ (means $\pm \mathrm{SD}$ ) and deviation from calculated Enslin numbers (\%) of binary powder mixtures without zinc acetate dihydrate.

\begin{tabular}{|c|c|c|c|c|c|c|}
\hline \multirow{2}{*}{$\begin{array}{l}\mathrm{Zn}-\mathrm{ac}: \mathrm{NaHCO}_{3}: \text { Metolose } \\
(\%)(\mathrm{w} / \mathrm{w} / \mathrm{w})\end{array}$} & \multicolumn{2}{|l|}{ LV } & \multicolumn{2}{|l|}{ MV } & \multicolumn{2}{|l|}{ HV } \\
\hline & Enslin number $(\mathrm{ml} / \mathrm{g})$ & Deviation (\%) & Enslin number $(\mathrm{ml} / \mathrm{g})$ & Deviation (\%) & Enslin number (ml/g) & Deviation (\%) \\
\hline $0: 10: 40$ & $0.930 \pm 0.084$ & 39.08 & $1.091 \pm 0.024$ & 45.84 & $1.342 \pm 0.025$ & 56.37 \\
\hline 015:35 & $0.930 \pm 0.100$ & 43.21 & $0.985 \pm 0.121$ & 45.76 & $1.332 \pm 0.024$ & 61.89 \\
\hline $0: 20: 30$ & $1.145 \pm 0.022$ & 59.49 & $1.090 \pm 0.043$ & 56.67 & $1.281 \pm 0.106$ & 66.56 \\
\hline $0: 25: 25$ & $1.184 \pm 0.062$ & 69.83 & $1.105 \pm 0.062$ & 65.15 & $1.372 \pm 0.206$ & 80.91 \\
\hline
\end{tabular}

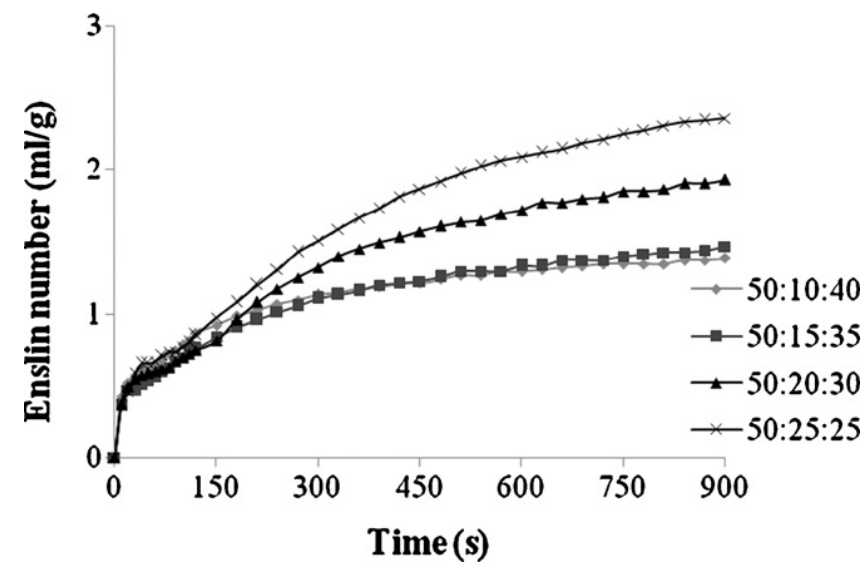

Fig. 2. Enslin numbers of ternary powder mixtures with LV. Znac: $\mathrm{NaHCO}_{3}$ :Metolose ratios $(\mathrm{w} / \mathrm{w} / \mathrm{w})$.

the amounts of water taken up were more than double. This interaction was also observed for the ternary powder mixtures, where higher amounts of water were taken up. The nature of this significant interaction which influenced the water-uptake properties of the powders appreciably must be studied in detail in the future.

$\mathrm{NaHCO}_{3}$ influenced not only the extent of the water uptake of the powder mixtures, but also the kinetics of this process (Fig. 2). In the first $3 \mathrm{~min}$, a step could be seen in all of the curves; this was most marked for the powder mixtures with LV.

\subsection{Study of tablet disintegration}

These tests were performed in consecutive steps. First, tablets prepared from the ternary powder mixtures were evaluated (Table 4). The tablets prepared from Metolose with different viscosities differed appreciably in behaviour. For LV, the time needed for disintegration of the tablets with the highest Metolose content was approximately $10 \mathrm{~min}$, which was slightly more than for the other compositions. Thus, there was no prolonging effect in these tablets: only a few minutes was necessary for the complete disintegration of the systems.

At higher viscosities, unexpected behaviour of the tablets was experienced. At $10 \% \mathrm{NaHCO}_{3}$ content, a higher initial value was observed for both MV and HV Metolose, and thus the effect of the effervescent component in these mixtures was not significant.

Table 4

Disintegration times $(\mathrm{min})$ of tablets prepared from ternary powder mixtures (means $\pm \mathrm{SD}$ ).

\begin{tabular}{lrll}
\hline $\begin{array}{l}\mathrm{Zn}-\mathrm{ac}: \mathrm{NaHCO}_{3}: \text { Metolose } \\
(\%)(\mathrm{w} / \mathrm{w} / \mathrm{w})\end{array}$ & $\mathrm{LV}$ & $\mathrm{MV}$ & $\mathrm{HV}$ \\
\hline $50: 10: 40$ & $10.5 \pm 0.8$ & $31.5 \pm 13.9$ & $>480.0$ \\
$50: 15: 35$ & $10.4 \pm 1.2$ & $15.2 \pm 4.3$ & $153.3 \pm 37.0$ \\
$50: 20: 30$ & $10.2 \pm 2.0$ & $21.6 \pm 6.0$ & $231.2 \pm 74.1$ \\
$50: 25: 25$ & $7.3 \pm 1.0$ & $80.2 \pm 10.2$ & $336.8 \pm 58.6$ \\
\hline
\end{tabular}

At higher $\mathrm{NaHCO}_{3}$ content, there was a continuous increase in the duration of disintegration. For these tablets, the disintegration time did not decrease with increasing amount of $\mathrm{NaHCO}_{3}$ as was expected on the basis of contact angle measurements, but continuously increased, so that there was a prolonged effect. The presumed interaction appeared to be proven, as the composition and consequently the properties of the powder mixtures changed on contact with water. The more significant the interaction was, the greater the extended behaviour of the system. It affected not only the wateruptake properties of the powder mixtures, but also the duration of disintegration.

To confirm this, other tests were performed. The duration of disintegration of the polymers and the binary powder mixtures containing $\mathrm{Zn}-\mathrm{ac}$ and the different forms of Metolose were also measured, was and were more than $8 \mathrm{~h}$ in every case. Hence, it can be stated that the presence of $\mathrm{NaHCO}_{3}$ is necessary for the detected disintegration time.

In the following step, the active agent, which is a necessary component of the interaction, was substituted with lactose monohydrate. The solubility of this component is similar to that of $\mathrm{Zn}-\mathrm{ac}$ in water and there is no known interaction between lactose and the other components. The disintegration time of the tablets was then measured again (Table 5). A decrease in the erosion time of the tablets was detected with increasing content of $\mathrm{NaHCO}_{3}$. This tendency was detected for every Metolose sample. In accordance with expectations, the binding effect of the smaller amount of polymer was insufficient to counteract the disintegration effect of the gas-forming component. These tests emphasized the importance of the interaction between the active and effervescent agent on the erosion of the dosage form.

\subsection{Buoyancy of matrix tablets}

The gastric floating system involved sodium bicarbonate as a gas-forming agent dispersed in the hydrogel matrix. On reacting with hydrochloric acid, the bicarbonate ion is converted to carbon dioxide in the form bubbles on the surface of the tablets, which caused the tablets to float in the fluid for more than $4 \mathrm{~h}$ in vitro. On the basis of the disintegration studies, it can be stated that only HV samples might be appropriate for the formulation of a floating drug delivery system. Thus, only these tablets were investigated further in this study; floating lag times and buoyancy (Fig. 3) were determined visually. The floating lag time for the samples containing $10 \%$ or $15 \% \mathrm{NaHCO}_{3}$ was shorter than $1 \mathrm{~min}$, while for the samples with $20 \%$ or $25 \%$ gas-forming agent it was $4.1 \pm 0.7 \mathrm{~min}$ and $3.5 \pm 0.3 \mathrm{~min}$,

Table 5

Disintegration times (min) of tablets prepared from powder mixtures containing lactose monohydrate (means $\pm \mathrm{SD}$ ).

\begin{tabular}{llll}
\hline $\begin{array}{l}\text { Lactose: } \mathrm{NaHCO}_{3}: \text { Metolose } \\
(\%)(\mathrm{w} / \mathrm{w} / \mathrm{w})\end{array}$ & $\mathrm{LV}$ & $\mathrm{MV}$ & $\mathrm{HV}$ \\
\hline $50: 10: 40$ & $46.1 \pm 9.1$ & $>480.0$ & $>480.0$ \\
$50: 15: 35$ & $23.8 \pm 1.6$ & $109.9 \pm 13.5$ & $>480.0$ \\
$50: 20: 30$ & $19.0 \pm 1.1$ & $62.8 \pm 10.4$ & $70.2 \pm 16.6$ \\
$50: 25: 25$ & $14.3 \pm 0.8$ & $13.7 \pm 1.2$ & $20.4 \pm 1.9$ \\
\hline
\end{tabular}



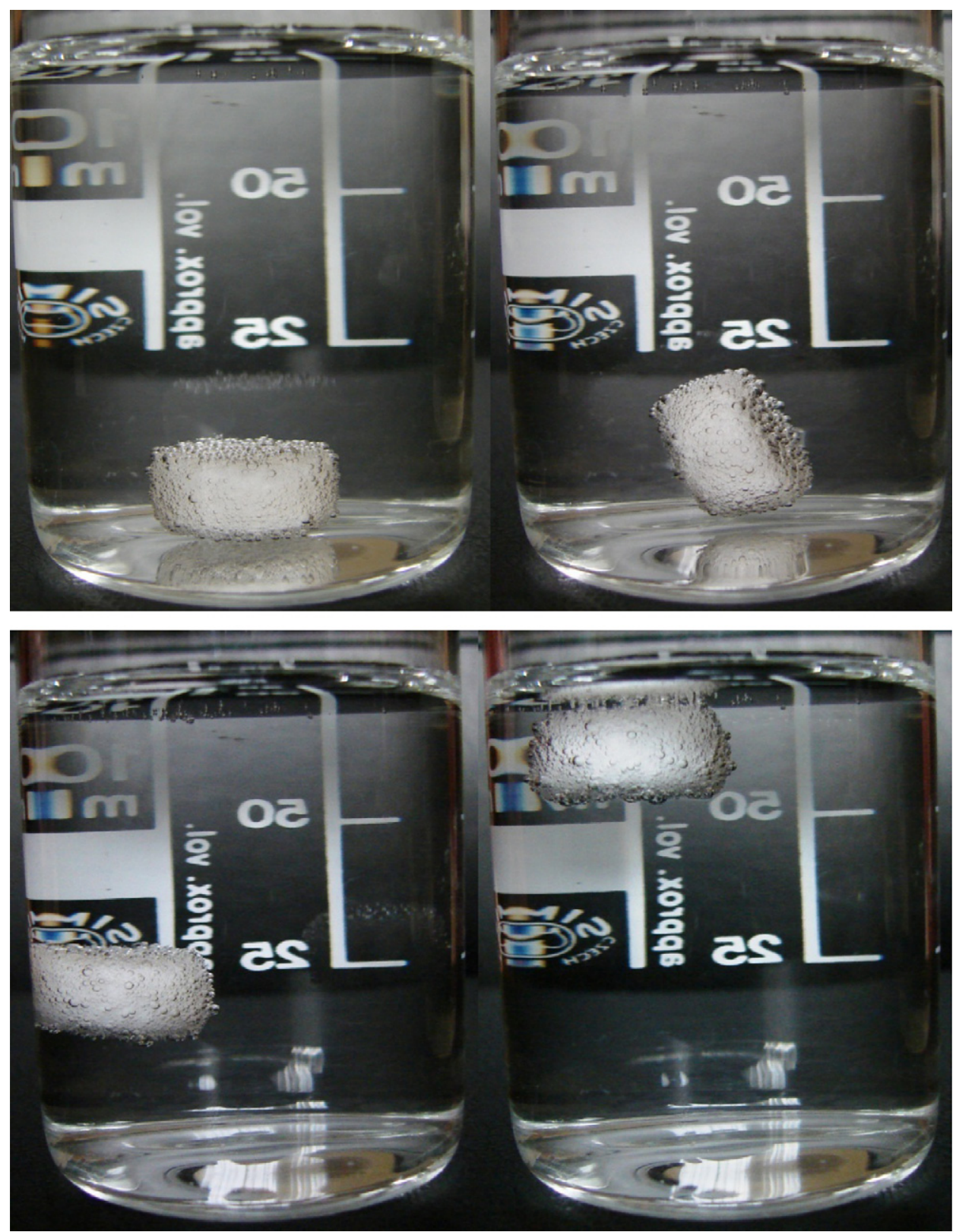

Fig. 3. Buoyancy of tablets ( $0-12 \mathrm{~min})$.

respectively. The samples with $10 \%$ or $15 \% \mathrm{NaHCO}_{3}$ content floated for only $17 \mathrm{~min}$ and $64 \mathrm{~min}$, respectively, which is not appropriate for the formulation of a floating system, whereas the samples with 20 or $25 \%$ gas-forming agent floated for a minimum of $4 \mathrm{~h}$.

\subsection{In vitro dissolution study}

From the results of the preformulation studies of the initial twelve compositions, the HV mixtures with higher $\mathrm{NaHCO}_{3}$ contents (20\% and $25 \%$ ) proved be appropriate for an extended release preparation. The dissolution characteristics of the sample with $20 \%$ gas-forming agent and 30\% Metolose were studied (Fig. 4). It was obvious, that the bulk of the active agent dissolved in the initial period of time after coming into contact with the gastric acid, while the dissolution of the remaining part was slow and continuous. The initial fast dissolution may be explained by the fact that the buoyancy of the floating tablet in the stomach started 4 min after its reaction with the gastric acid; during this time, the evolving gas

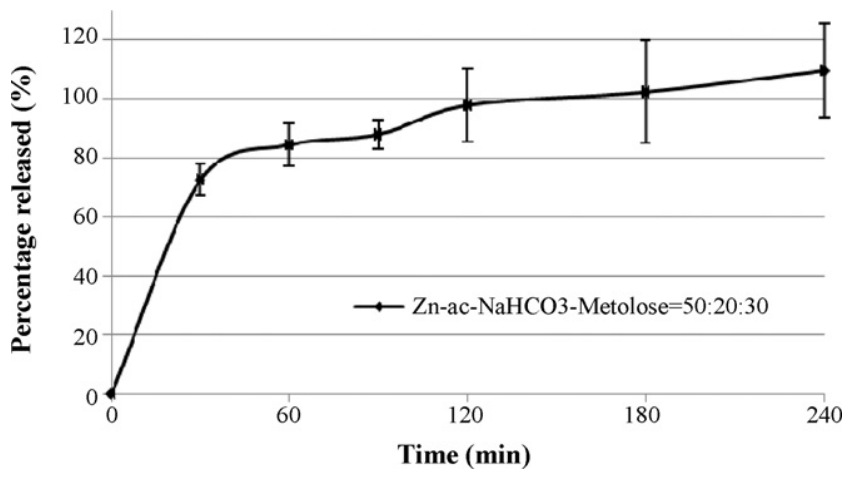

Fig. 4. Dissolution study. 
permeated through the matrix leaving gas bubbles or pores which could have increased the rate of release of the active ingredient from the matrix. After that time, the gas bubbles were entrapped in the gel layer, which could have slowed down the dissolution.

\section{Conclusions}

Appropriate systems with prolonged disintegration times, appropriate buoyancy and controlled release can be formulated from $\mathrm{Zn}$-ac by using $\mathrm{NaHCO}_{3}$ as gas-forming agent and Metolose 90 SH 100,000 SR as a matrix and gel-forming component. In this case, the low viscosity grades of the polymer were not appropriate. Alteration of the ratio of the excipients resulted in an unpredicted significant influence on the properties of the dosage form. The interaction between $\mathrm{Zn}-\mathrm{ac}$ and $\mathrm{NaHCO}_{3}$ caused a relevant modification in the water uptake of the powder mixture and in the disintegration of the tablets. Independent tests revealed an interaction between these two components when they came into contact with water, so that prediction of the properties of the dosage form from the parameters of the starting components was impossible. This phenomenon was applied to develop a prolonged effect. Through investigation of the nature of this interaction, a better understanding of the process may be achieved. These technological aspects must therefore be studied with different chemical and biopharmaceutical tests. This is a good example of significant changes induced by interaction in the parameters of a new sensitive delivery system.

The floating study clarified what compositions may be suitable for the formulation of a controlled delivery system. The dissolution study demonstrated that the $\mathrm{HV}$ mixture with a higher $\mathrm{NaHCO}_{3}$ content appeared appropriate for an extended release preparation, and this composition will therefore be investigated from a chemical aspect in the future. As the liberation of zinc in absorbable form can be achieved, it will be favourable if the interaction is controllable. These results may therefore be useful in the development from $\mathrm{Zn}$-ac of a sustained release dosage form with a prolonged gastric residence time for the treatment of Wilson disease.

\section{References}

[1] A.F. Hefti, B. Huber, The effect on early plaque formation, gingivitis and salivary bacterial counts of mouthwashes containing hexetidine/zinc, aminefluoride/tin or chlorhexidine, J. Clin. Periodontol. 14 (2005) 515-518.

[2] P. Little, Zinc acetate lozenges reduced the duration and severity of symptoms of the common cold, Evid. Based Med. 6 (2001) 46.

[3] M. Frydman, Genetic aspects of Wilson's disease, J. Gastroenterol. Hepatol. 5 (1990) 483-490.

[4] P.C. Bull, G.R. Thomas, J.M. Rommens, J.R. Forbes, D.W. Cox, The Wilson disease gene is a putative copper transporting P-type ATPase similar to the Menkes gene, Nat. Genet. 5 (1993) 327-337.

[5] R.E. Tanzi, K. Petrukhin, I. Chernov, J.L. Pellequer, W. Wasco, B. Ross, et al., The Wilson disease gene is a copper transporting ATPase with homology to the Menkes disease gene, Nat. Genet. 5 (1993) 344-350.

[6] J. Nagy, Z. Vincze, A. Folhoffer, A. Horváth, T. Csák, R. Zelkó, The pathomechanism and treatment of Wilson disease, Acta Pharm. Hung. 73 (2004) 237-241.

[7] T.U. Hoogenraad, J. Van Hattum, C.J. Van den Hamer, Management of Wilson's disease with zinc sulphate. Experience in a series of 27 patients, J. Neurol. Sci. 77 (1987) 137-146.

[8] T.U. Hoogenraad, R. Koevoet, E.G. de Ruyter Korver, Oral zinc sulphate as long-term treatment in Wilson's disease (hepatolenticular degeneration), Eur. Neurol. 18 (1979) 205-211.
[9] G.J. Brewer, R.D. Dick, V.D. Johnson, J.A. Brunberg, K.J. Kluin, J.K. Fink, Treatment of Wilson's disease with zinc. XV. Long-term follow-up studies, J. Lab. Clin. Med. 132 (1999) 264-278.

[10] M. Schilsky, R.R. Blank, M.J. Czaja, I.H. Scheinberg, R.J. Stockert, I. Sternlieb, Hepatocellular copper toxicity and its attenuation by zinc, J. Clin. Invest. 84 (1989) 1562-1568.

[11] G.M. Hill, G.J. Brewer, A.S. Prasad, C.R. Hydrick, D.E. Hartmann, Treatment of Wilson's disease with zinc. I. Oral zinc therapy regimens, Hepatology 7 (1987) 522-528.

[12] R.J. Cousins, Absorption, transport and hepatic metabolism of copper and zinc: special reference to metallothionein and ceruloplasmin, Physiol. Rev. 65 (1985) 238-309.

[13] G.J. Brewer, G.M. Hill, A.S. Prasad, Z.T. Cossack, P. Rabbani, Oral zinc therapy for Wilson's disease, Ann. Intern. Med. 99 (1983) 314-319.

[14] E.A. Roberts, M.L. Schilsky, A practice guideline on Wilson disease, Hepatology 37 (2003) 1475-1492.

[15] N.F. Krebs, J.E. Westcott, J.W. Huffer, L.V. Miller, Absorption of exogenous zinc and secretion if endogenous zinc in the human small intestine, FASEB J. 12 (1998) A345, 345-348.

[16] H.H. Lee, A.S. Prasad, G.J. Brewer, C. Owyang, Zinc absorption in human small intestine, Am. J. Physiol. 256 (1989) G87-G91.

[17] A. Bernkop-Schnürch, Mucoadhesive systems in oral drug delivery, Drug. Discov. Today 2 (2005) 83-87.

[18] J. Wang, Y. Tabata, D. Bi, K. Morimoto, Evaluation of gastric mucoadhesive properties of aminated gelatin microspheres, J. Control Release 73 (2001) 223-231.

[19] J.A. Fix, R. Cargill, K. Engle, Controlled gastric emptying. Part 3. Gastric residence time of a nondisintegrating geometric shape in human volunteers, Pharm. Res. 10 (1993) 1087-1089.

[20] F. Atyabi, H.L. Sharma, H.A.H. Mohammad, J.T. Fell, In vivo evaluation of a nove gastric retentive formulation based on ion exchange resins, J. Control Release 42 (1996) 105-113.

[21] V. Iannuccelli, G. Coppi, R. Sansone, G. Ferolla, Air compartment multiple-unit system for prolonged gastric residence. Part II. In vivo evaluation, Int. J. Pharm. 174 (1998) 55-62.

[22] S. Sungthongjeen, O. Paeratakul, S. Limmatvapirat, S. Puttipipatkhachorn, Preparation and in vitro evaluation of a multiple-unit floating drug delivery system based on gas formation technique, Int. J. Pharm. 324 (2006) 136-143.

[23] B.Y. Choi, H.J. Park, S.J. Hwang, J.B. Park, Preparation of alginate beads for floating drug delivery system: effects of $\mathrm{CO}_{2}$ gas-forming agents, Int. J. Pharm. 239 (2002) 81-91

[24] I. Jiménez-Martínez, L. Quirino-Barreda, Villafuerte-Robles, Sustained delivery of captopril from floating matrix tablets, Int. J. Pharm. 362 (2008) 37-43.

[25] N. Rouge, P. Buri, E. Doelker, Drug absorption sites in the gastrointestina tract and dosage forms for site-specific delivery, Int. J. Pharm. 136 (1996) 117-139.

[26] B.S. Dave, A.F. Amin, M.M. Patel, Gastroretentive drug delivery system of ranitidine hydrochloride: formulation and in vitro evaluation, AAPS Pharm. Sci. Technol. 5 (2004) A34, 1-6.

[27] P. Sriamornsak, N. Thirawong, K. Korkerd, Swelling, erosion and release behaviour of alginate-based matrix tablets, Eur. J. Pharm. Biopharm. 66 (2007) 435-450.

[28] V. Kudela, Hydrogels, in: Encyclopedia of Polymer Science and Engineering, vol. 7. Wiley, New York, 1987, pp. 703-807.

[29] E. Cedillo-Ramírez, A. Hernández-León, L. Villafuerte-Robles, Effect of added pharmatose DCL11 on the sustained-release of metronidazole from Methocel K4M and Carbopol 971P NF floating matrices, Drug Dev. Ind. Pharm. 32 (2006) 955-965.

[30] W.M. Hlaing, M.D. McCluskeya, A.D. Lalonde, M.G. Norton, Infrared spectroscopy of $\mathrm{ZnO}$ nanoparticles containing $\mathrm{CO}_{2}$ impurities, Appl. Phys. Lett. 86 (2005) 073111,1-3.

[31] X. Xiaoqiang, S. Minjie, Z. Feng, H. Yiqiao, Floating matrix dosage form for phenoporlamine hydrochloride based on gas forming agent: in vitro and in vivo evaluation in healthy volunteers, Int. J. Pharm. 310 (2006) 139-145.

[32] E. Nürnberg, P. Surmann (Eds.), Hagers Handbuch der Pharmazeutischen Praxis, 5th ed., Bd. 2 Methoden, Springer Verlag, Berlin, 1991, p. 60.

[33] K.A. Kelly, Motility of the stomach and gastroduodenal junction, in: L.R. Johnson (Ed.), Physiology of the Gastrointestinal Tract, vol. 1, 1st ed., Raven Press, New York, 1981, pp. 393-410.

[34] E.A. Klausner, E. Lavy, M. Friedman, A. Hoffman, Expandable gastroretentive dosage forms, J. Control Release 90 (2003) 143-162.

[35] C.R. Rowe, P.J. Sheskey, P.J. Weller, Handbook of Pharmaceutical Excipients, 4th ed., Pharmaceutical Press, London, 2003, pp. 263-265. 